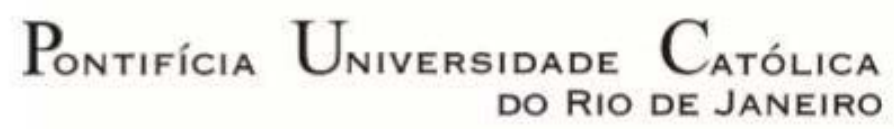

DO RIO DE JANEIRO

Caroline Sampaio de Almeida

O Porto Maravilha e a sustentabilidade urbana

Dissertação de Mestrado

Dissertação apresentada ao Programa de PósGraduação em Arquitetura e Urbanismo da PUC-Rio como requisito parcial para obtenção do grau de Mestre em Arquitetura.

Orientadora: Prof. ${ }^{a}$ Maria Fernanda Lemos

Rio de Janeiro

Maio de 2019 


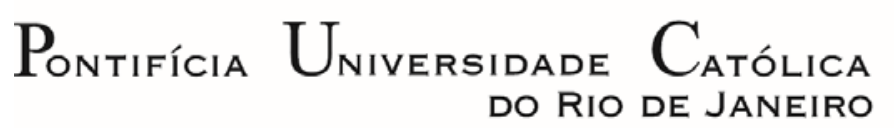

DO RIO DE JANEIRO

Caroline Sampaio de Almeida

\title{
O Porto Maravilha e a sustentabilidade urbana
}

\begin{abstract}
Dissertação apresentada como requisito parcial para a obtenção do grau de Mestre pelo Programa de Pós-Graduação em Arquitetura da PUC-Rio. Aprovada pela Comissão Examinadora abaixo assinada.
\end{abstract}

Prof. ${ }^{a}$ Dra. Maria Fernanda Lemos Orientadora Departamento de Arquitetura e Urbanismo - PUC-Rio

Prof. ${ }^{a}$ Dra. Maíra Martins Departamento de Arquitetura e Urbanismo - PUC-Rio

Prof. ${ }^{a}$ Dra. Laura Silva Valente de Macedo Fundação Getulio Vargas

Prof. a Dra. Angelica Benatti Alvim Universidade Presbiteriana Mackenzie

Dr. Rolf Bateman Hippertt Hatje Fundação Roberto Marinho

Rio de Janeiro, 20 de maio de 2019 
Todos os direitos reservados. É proibida a reprodução total ou parcial do trabalho sem autorização da universidade, da autora e da orientadora.

Caroline Sampaio de Almeida

Graduou-se em Arquitetura e Urbanismo na Universidade Faculdade Federal Fluminense (UFF) em 2010. Cursou MBA em Gestão de Projetos no IBMEC em 2011. Trabalhou na elaboração da Agenda Socioambiental da PUC-Rio junto ao Núcleo Interdisciplinar de Meio Ambiente (Nima) e participou de seminários e congressos na área da arquitetura e urbanismo.

Ficha Catalográfica

Almeida, Caroline Sampaio de

O Porto Maravilha e a sustentabilidade urbana / Caroline Sampaio de Almeida ; orientadora: Maria Fernanda Lemos. 2019.

157 f. : il. color. ; $30 \mathrm{~cm}$

Dissertação (mestrado)-Pontifícia Universidade Católica do Rio de Janeiro, Departamento de Arquitetura e Urbanismo, 2019.

Inclui bibliografia

1. Arquitetura e Urbanismo - Teses. 2. Urbanismo. 3. Desenvolvimento sustentável. 4. Sustentabilidade. 5. Sustentabilidade urbana. 6. Porto Maravilha. I. Lemos, Maria Fernanda. II. Pontifícia Universidade Católica do Rio de Janeiro. Departamento de Arquitetura e Urbanismo. III. Título. 


\section{Dedicatória}

À minha mãe, Vânia da Cunha Sampaio, Que, com seu amor incondicional, sempre esteve ao meu lado, me apoiando em todas os meus passos. Sem ela, eu não teria conseguido concluir este trabalho.

Ao meu pai, Horácio Antônio de Almeida (in memoriam), que eternamente me inspira a fazer sempre o meu melhor e a me tornar alguém de quem ele se orgulhasse.

À minha avó, Léa da Cunha Sampaio, que me ensinou que, sem amor, sem carinho e sem verdadeiros amigos, a vida torna-se vazia e amarga.

Tudo o que sou tem um pouco de vocês. 


\section{Agradecimentos}

À Pontifícia Universidade Católica do Rio de Janeiro (PUC-Rio), por acolher tantos alunos com o compromisso de fornecer ensino superior de qualidade e formação de pensamento crítico.

À Coordenação de Aperfeiçoamento de Pessoal de Nível Superior (CAPES), pelos auxílios concedidos, sem os quais não teria sido possível concluir o trabalho aqui apresentado.

À minha orientadora, Maria Fernanda Lemos, pelas palavras inspiradoras e sabedoria compartilhada de forma tão generosa.

Às professoras doutoras Angelica Benatti, Laura Macedo e Maíra Martins, e ao pesquisador doutor Rolf Bateman, que aceitaram tão prontamente o convite de participar da banca, contribuindo de forma significativa para o meu desenvolvimento acadêmico.

À Renata Dias, por todo apoio dado aos alunos longo do nosso curso na PUC-Rio, sempre de forma tão eficiente e atenciosa.

Aos amigos de turma, por compartilharem tantos cafés, vinhos, conselhos, sorrisos, abraços e palavras ao longo dos últimos dois anos e que tornaram essa jornada mais leve e prazerosa.

À minha família, especialmente à minha mãe, Vânia, e ao meu padrasto, Wander, por compreenderem minha ausência, serem meu alicerce e me darem o suporte necessário para que eu pudesse buscar os meus sonhos.

A todos os amigos que contribuíram de alguma forma para a elaboração deste trabalho, principalmente a Lívia, Chebel, Tamara, Renata, Rodrigo, Débora, Alberto, Bat e Andressa, que nessa reta final e ao longo da pesquisa estiveram presentes e se dispuseram a me ajudar com tanto carinho.

Ao meu analista, Fernando Baron, por ter me incentivado a me apaixonar pelo meu trabalho, quando muitas vezes tive vontade de desistir.

Aos moradores do Morro da Conceição, Morro do Pinto e Morro da Providência, por terem me recebido de braços abertos em suas casas durante a elaboração da pesquisa e acreditado no potencial do presente trabalho.

O presente trabalho foi realizado com o apoio da Coordenação de Aperfeiçoamento de Pessoal de Nível Superior - Brasil (CAPES) - Código de Financiamento 001. 


\section{Resumo}

Almeida, Caroline Sampaio de; Lemos, Maria Fernanda. O Porto Maravilha e a sustentabilidade urbana. Rio de Janeiro, 2019. 157 p. Dissertação de Mestrado - Departamento de Arquitetura e Urbanismo, Pontifícia Universidade Católica do Rio de Janeiro.

Tendo em vista que a sustentabilidade urbana é um dos principais desafios da atualidade em face do crescimento e do adensamento das grandes cidades e áreas metropolitanas, urge a necessidade de compreender a abordagem que está sendo dada ao tema dentro do contexto das intervenções urbanas mais recentes. Partindo da premissa básica de que não é possível haver desenvolvimento sustentável sem que seja considerada, em sua essência, sua característica multidisciplinar, a concepção de novos projetos deve abranger os aspectos econômicos, sociais e ecológicos de forma simultânea e integrada. A presente pesquisa tem como objetivo verificar se o projeto elaborado para o Porto Maravilha contribui para a sustentabilidade urbana ao longo da região portuária na cidade do Rio de Janeiro. A partir de uma reflexão teórica, foram elaborados critérios de análise geral que possibilitassem a compreensão de como os aspectos de sustentabilidade foram aplicados na região de maneira mais ampla e integrada. Por meio da pesquisa de campo, bem como dos documentos disponibilizados pela Companhia de Desenvolvimento Urbano do Porto do Rio de Janeiro (CDURP), foi possível realizar uma análise dos critérios estipulados previamente ao longo do trabalho. Por fim, por meio de uma representação cartográfica que sintetiza os resultados obtidos pela pesquisa, foi possível verificar que o Porto Maravilha não atende aos aspectos de sustentabilidade preestabelecidos pela metodologia proposta de forma equitativa, visto que não contempla sua distribuição de forma mais ampla e integrada entre os diversos setores do projeto.

\section{Palavras-chave}

Desenvolvimento sustentável; sustentabilidade; sustentabilidade urbana; Porto Maravilha. 


\section{Abstract}

Almeida, Caroline Sampaio de; Lemos, Maria Fernanda (Advisor). Porto Maravilha and the urban sustainability. Rio de Janeiro, 2019. 157 p. Dissertação de Mestrado - Departamento de Arquitetura e Urbanismo, Pontifícia Universidade Católica do Rio de Janeiro.

Given that urban sustainability is one of the current main challenges in what concerns big cities and metropolitan areas growth and densification, the need to understand the chosen approach for the theme in the most recent urban interventions urges. Considering the impossibility of sustainable development without taking in account it's essential multidisciplinarity as a basic premise, new urbanization projects conception must comprehend economic, social and ecologic aspects in an integrated and simultaneous way. This research aims to verifying if Porto Maravilha's Project in Rio de Janeiro city has contributed for the region's sustainability. Using a specific bibliography, general analysis criteria have been formulated to allow the understanding of how sustaintability aspects were applied in the region in the widest and most integrated way. Throughout field research and other documents it was possible to perform a sustainability analysis based on the criteria previously defined by the methodology developed throughout the paper. In conclusion, based on a cartographic representation which synthesizes the research results, it was possible to verify that Porto Maravilha does not comply with equality the pre-determined sustainability aspects proposed by the suggested methodology, given that it does not fulfil its distribution on the widest and most integrated way among the project's diversified sectors.

\section{Keywords}

Sustainable development; sustainability; urban sustainability; Porto Maravilha. 


\section{Sumário}

1. Introdução

2. Sustentabilidade, desenvolvimento sustentável e sustentabilidade urbana

2.1. A crise socioambiental e o futuro das cidades

2.2. Sustentabilidade e desenvolvimento sustentável 30

2.3. Sustentabilidade urbana

3. Metodologia para análise dos aspectos socioambientais e as contribuições para a sustentabilidade de projetos urbanos

3.1. Dimensões, categorias e critérios

45

3.1.1. Dimensões

45

3.1.1.1. Dimensão ecológica

46

3.1.1.2. Dimensão sociocultural

47

3.1.2. Categorias e critérios

50

3.1.2.1. Categorias de análise

50

3.1.2.1.1. Eficiência energética 50

3.1.2.1.2. Poluição do ar 50

3.1.2.1.3. Recursos hídricos 50

3.1.2.1.4. Resíduos sólidos 51

3.1.2.1.5. Aprazibilidade 51

3.1.2.1.6. Identidade e cultura 52

3.1.2.1.7. Diversidade 53

3.1.2.1.8. Inclusão e equidade $\quad 53$

3.1.2.1.9. Critérios de análise $\quad 53$

3.1.2.1.9.1. Lista de critérios $\quad 54$

3.2. Sistematização das informações $\quad 55$

3.2.1. Elaboração dos mapas das categorias individuais 55

3.2.2. Elaboração do mapa geral 56

3.3. Considerações metodológicas $\quad 57$

3.3.1. Tipo de pesquisa $\quad 57$

3.3.2. Definição da amostragem $\quad 57$

4. Estudo de caso: aspectos de sustentabilidade do Porto Maravilha $\quad 61$

4.1. O Porto Maravilha $\quad 61$

4.2. Processos de ruptura 64

4.3. Definição dos critérios de sustentabilidade urbana no projeto do Porto Maravilha $\quad 68$

4.3.1. Iluminação e energia 68 
4.3.1.1. Definição, no projeto, de parâmetros construtivos de afastamento e gabarito que permitam a entrada de luz natural em todas as unidades de residência e trabalho

4.3.1.2. Instalação de iluminação artificial nas áreas públicas 71

4.3.2. Mobilidade

72

4.3.2.1. Atendimento da área por pontos de ônibus e veículo leve sobre trilhos (VLT)

4.3.2.2. Atendimento da área por sistemas de transporte de massa

4.3.2.3. Atendimento da área por ciclovias e calçadas que favoreçam o transporte não motor

4.3.2.4. Redução de vias geradoras de trânsito e ruídos no entorno

4.3.3. Ocupação do solo

81

4.3.1. Adequação do projeto urbano para atendimento do aumento da densidade prevista pelos Cepacs

82

4.3.2. Atendimento da área por usos e equipamentos diversos

85

4.3.4. Arborização urbana

85

4.3.4.1. Plantio de novas árvores novas árvores e áreas verdes

86

4.3.5. Infraestrutura - redes de água, esgoto e drenagem

87

88

4.3.5.1. Instalação rede de água, esgoto e drenagem

89

4.3.5.2. Aplicação de medidas para evitar alagamentos em

regiões urbanizadas pelas chuvas ou elevação do nível do mar

89

4.3.6. Gestão dos resíduos sólidos

91

4.3.6.1. Redução do acúmulo de lixo nas calçadas

91

4.3.6.2. Instalação de lixeiras no mobiliário e para a coleta seletiva

4.3.7. Preservação e valorização do patrimônio

93

4.3.7.1. Valorização do patrimônio arquitetônico com presença significativa de imóveis tombados/preservados

4.3.7.2. Valorização e preservação de áreas arqueológicas

4.3.8. Áreas de cultura e lazer

96

97

4.3.8.1. Atendimento da área por praças, centros esportivos e áreas de lazer com infraestrutura

4.3.8.2. Atendimento de áreas por museus e centros culturais 102

4.3.9. Acessibilidade

103

4.3.9.1. Atendimento por espaços públicos acessíveis 105

4.3.10. Habitação

106

4.3.10.1. Construção de novas moradias voltadas para a habitação popular

4.3.10.2. Manutenção da população local, não se realizando remoções compulsórias 
4.3.11.1. Participação da população envolvida em sua concepção 111

4.3.12 Equipamentos urbanos 113

4.3.12.1 Atendimento da área por escolas, creches e hospitais 113

4.3.13 Diversidade 114

4.3.13.1 Existência de diferentes padrões habitacionais, equipamentos e usos $\quad 114$

4.4 Resultados 115

$\begin{array}{ll}\text { 4.4.1 Eficiência energética } & 115\end{array}$

$\begin{array}{ll}\text { 4.4.2 Poluição do ar } & 118\end{array}$

4.4.3 Recursos hídricos $\quad 121$

4.4.4 Resíduos sólidos $\quad 122$

4.4.5 Aprazibilidade 124

$\begin{array}{ll}\text { 4.4.6 Identidade e cultura } & 127\end{array}$

$\begin{array}{ll}\text { 4.4.7 Diversidade } & 130\end{array}$

$\begin{array}{ll}4.4 .8 \text { Inclusão e equidade } & 133\end{array}$

$\begin{array}{ll}4.5 \text { Resultado geral } & 137\end{array}$

5. Conclusão 139

6. Referências bibliográficas 142

Anexo 1 - Planta geral das obras executadas fornecida pela CDURP 147

Anexo 2 - Planta de gabaritos propostos fornecida pela CDURP 148

Anexo 3 - Entrevista com o engenheiro civil Antônio Carlos,

diretor e presidente da CDURP

149

$\begin{array}{ll}\text { Anexo } 4 \text { - Modelo de questionário elaborado } & 157\end{array}$ 


\section{Lista de figuras}

Figura 1 - Mapa do Porto Maravilha e sub-regiões propostas pelo projeto.

Figura 2 - Características da sustentabilidade urbana.

Figura 3 - Características da sustentabilidade.

Figura 4 - Relação entre custo de infraestrutura e densidade.

Figura 5 - Vantagens versus desvantagens de acordo com a densidade.

Figura 6 - Modelo de metabolismo urbano.

Figura 7 - Matrizes discursivas da sustentabilidade urbana.

Figura 8 - Diagrama da relação entre princípios e critérios.

Figura 9 - Metodologia para elaborar os mapas de cada categoria.

Figura 10 - Esquema gráfico da metodologia para elaboração do mapa final.

Figura 11 - Mapa com as regiões onde foram realizadas as entrevistas da pesquisa.

Figura 12 - Mapa da área do Porto Maravilha com setores propostos pelo plano.

Figura 13 - Mapa da relação de propriedade dos terrenos do

Porto Maravilha.

Figura 14 - Mapa da infraestrutura executada versus prevista do Porto Maravilha.

Figura 15 - Mapa dos gabaritos propostos Porto Maravilha.

Figura 16 - Situação proposta para o Boulevard e a Via Binário.

Figura 17 - Mapa de mobilidade do Porto Maravilha.

Figura 18 - Teleférico do Morro da Providência.

Figura 19 - Imagem do Boulevard Olímpico.

80

Figura 20 - Mapa de previsão de ruídos na região do Porto Maravilha. 
Figura 21 - Mapa de diversidade de usos e equipamentos.

Figura 22 - Mapa de arborização urbana do Porto Maravilha.

Figura 23 - Situação futura da rede de esgoto e ETE existente na região do Porto Maravilha.

Figura 24 - Áreas alagáveis.

Figura 25 - Situação futura: desaguamento de águas pluviais no Porto Maravilha.

Figura 26 - Acúmulo de lixo no largo São Francisco da Prainha.

Figura 27 - Acúmulo de lixo no Morro da Providência.

Figura 28 - Acúmulo de lixo e entulho no Morro da Providência próximo à escadaria.

Figura 29 - Acúmulo de lixo próximo à Central do Brasil.

Figura 30 - Coleta de lixo no Morro do Pinto.

Figura 31 - Mapa áreas de preservação e conservação arquitetônica e arqueológica.

Figura 32 - Circuito da Herança africana.

Figura 33 - Cais do Valongo/Imperatriz.

Figura 34 - Fachada da sede do projeto Filhos de Gandhi ao lado dos Jardins do Valongo.

Figura 35 - Parque Olímpico — vista do Mirante da Providência. 100

Figura 36 - Parque Machado de Assis.

Figura 37 - Área antiga da quadra do Morro da Providência.

Figura 38 - Parque Machado de Assis, com área de lazer e esporte. 101

Figura 39 - Jardim do Valongo.

Figura 40 - Museu do Amanhã.

Figura 41 - Museu de Arte do Rio (MAR).

Figura 42 - População carregando material de obra no ombro na escadaria do Morro da Providência.

Figura 43 - Calçada estreita, impossibilitando a acessibilidade setor $\mathrm{C}$.

Figura 44 - Calçada estreita, impossibilitando a acessibilidade setor D. 
Figura 45 - Calçada estreita, impossibilitando a acessibilidade setor $\mathrm{J}$.

Figura 46 - Calçada estreita, impossibilitando a acessibilidade setor L.

Figura 47 - Mapa de remoções e Minha Casa, Minha Vida (MCMV).

Figura 48 - Sinal da Secretaria Municipal de Habitação (SMH) em residência que havia sido marcada para ser removida no Morro da Providência.

Figura 49 - Edifício da fachada antiga da ocupação Casarão Azul. 108

Figura 50 - Protestos contra a construção do teleférico no Morro da Providência.

Figura 51 - Protestos dos moradores da Providência.

Figura 52 - Local de onde foram removidas 20 casas para a construção do teleférico.

Figura 53 - Mapa de eficiência energética.

Figura 54 - Mapa de poluição do ar.

Figura 55 - Mapa de recursos hídricos.

Figura 56 - Mapa de resíduos sólidos.

Figura 57 - Mapa de aprazibilidade.

Figura 58 - Mapa de identidade e cultura.

Figura 59 - Mapa de diversidade.

Figura 60 - Mapa Inclusão e equidade.

Figura 61 - Mapa de resultado final. 


\section{Lista de tabelas}

Tabela 1 - Cálculo da emissão de gases - situação anterior e futura.

Tabela 2 - Meio de transporte dos moradores.

Tabela 3 - Entrevistas no local. Frequência no Museu do Amanhã ou no MAR.

Tabela 4 - Tabela de ocupações.

Tabela 5 - Eficiência energética.

Tabela 6 - Poluição do ar.

Tabela 7 - Recursos hídricos.

Tabela 8 - Resíduos sólidos.

Tabela 9 - Aprazibilidade.

Tabela 10 - Identidade e cultura.

Tabela 11 - Diversidade.

Tabela 12 - Inclusão e equidade.

Tabela 13 - Resultado geral. 
Nós os homens construímos Os nossos cais nos nossos portos, Os nossos cais de pedra actual sobre água verdadeira, Que depois de construídos se anunciam de repente Coisas-Reais, Espíritos-Coisas, Entidades em Pedra-Almas.

A certos momentos nossos de sentimento-raiz Quando no mundo-exterior como que se abre uma porta $E$, sem que nada se altere, Tudo se revela diverso.

Alvares de Campos (Fernando Pessoa), Ode marítima. 


\section{1 Introdução}

Vivemos, atualmente, uma inerente crise socioambiental. A ideia de desenvolvimento vinculada ao crescimento e à dominação do ser humano sobre a natureza reforça a forma como a relação homem-natureza e sociedade-ambiente é vista de forma fragmentada, apesar de estarem intimamente conectados.

O desenvolvimento sustentável e seu compromisso com as gerações futuras é condição fundamental para a sobrevivência e o desenvolvimento humano. Os riscos associados à crise que atravessamos têm sua origem em eventos tanto naturais quanto antrópicos. Dessa maneira, é fundamental repensarmos os impactos gerados pela ação humana junto ao meio ambiente e à sociedade.

A cidade tanto gera impactos sobre o meio ambiente quanto sofre com seus efeitos. Ao considerarmos a vulnerabilidade das cidades diante dos riscos de possíveis choques provenientes de eventos de origem natural e antrópica, faz-se, portanto, relevante uma maior reflexão sobre o tema e como ele tem sido aplicado nos projetos urbanos atuais.

Sustentabilidade é um conceito multidimensional (Porto-Gonçalves, 2016) e contínuo (Uzzel, 2002), podendo ser aplicado em sistemas abertos e dinâmicos, que incluem sistemas industriais, sociais e naturais (Sartori, Lartori, Latrônico \& Campos, 2014). O conceito paradigmático e temporal de entendimento a respeito do desenvolvimento sustentável (Sachs, 2008) tem ampla interpretação entre os diversos setores da sociedade, que apresentam questões norteadoras distintas sobre o tema de acordo com o cerne de aplicação.

O desenvolvimento baseado no crescimento econômico como imperativo estratégico para a redução da pobreza (Comissão Mundial sobre Meio Ambiente e Desenvolvimento, 1988) tem caráter contraditório em sua essência. Se, por um lado, a pobreza é um grande fator de vulnerabilidade, por outro seria impossível alcançar o desenvolvimento sustentável mantendo o padrão de consumo baseado em uma lógica linear de crescimento e acúmulo de bens. Assim, é impossível considerar que, para diminuir a desigualdade, bastaria somente buscar a igualdade, se ela estiver focada apenas em tentar aumentar o padrão de crescimento das camadas 
sociais mais pobres, sem questionar o padrão de consumo das classes privilegiadas (Porto-Gonçalves, 2016).

Não é possível, portanto, sustentar a busca do desenvolvimento baseado no acúmulo de bens, visto que os recursos são finitos e distribuídos de forma desigual. O intuito de promover a igualdade baseado principalmente no crescimento econômico, como forma de combater a desigualdade, reitera a ideia de colonialidade do saber e poder, já que o modelo de igualdade pretendido permanece dentro do pensamento único e moderno-colonial da Europa e dos EUA (Porto-Gonçalves, 2016).

Acselrad (2009) considera que o discurso hegemônico da sustentabilidade tem dupla dimensão, sendo a primeira uma dimensão prática — que visa a manter a materialidade da cidade, tornando-a também mais funcional para o capital - e a segunda retórica - que incorpora os ideais ambientalistas como forma de neutralizar as críticas, legitimar as políticas públicas e aumentar a capacidade competitiva das cidades.

Ao descrever a prática de um urbanismo de resultados, o autor (Acselrad, 2009) também destaca como ela estimula a disputa entre cidades. Dessa maneira, o modelo abordado destina-se apenas a uma minoria recursos importantes, que seriam aplicados em políticas sociais, o que pode ressaltar ainda mais as desigualdades. Como a maioria dos recursos muitas vezes é destinada prioritariamente aos setores que podem promover maior retorno econômico, a maior parte da população, portanto, permanece sem acesso às inovações tecnológicas, socioculturais e ecológicas. Tal fato pode aumentar os conflitos e as desigualdades, gerando um processo de regressão social e dependência.

Segundo Porto-Gonçalves (2016), a ideia de desenvolvimento está diretamente associada à busca da dominação da natureza, segundo a qual ser desenvolvido envolve a ligação com construções feitas pelo ser humano. Nessa visão, ainda de acordo com o autor, a ideia de desenvolvimento está relacionada com ser industrializado e urbano. Portanto, é justamente na tensão entre a modernidade e a sustentabilidade ecológica que se reafirmam os objetivos contraditórios do desenvolvimento sustentável (Souza, 2002).

As grandes cidades apresentam, atualmente, um crescimento exponencial. No Brasil, um terço da população está concentrada em apenas nove áreas metropolitanas (Acselrad, 2009). O processo de urbanização - que, conforme mencionado anteriormente, muitas vezes é associado à ideia de modernidade - 
deve considerar que, quanto maior a concentração de recursos e pessoas, maiores também são as tensões e os impactos gerados por possíveis choques sociais ou ambientais (UN-Habitat III). O alcance e a abrangência das ameaças naturais e antrópicas podem colocar em risco a sobrevivência das cidades, sendo as áreas mais pobres as mais suscetíveis a seus danos.

A Nova Agenda Urbana proposta pelo $\mathrm{ONU}^{1}$ reconhece que a organização espacial e os projetos urbanos, juntamente com as políticas públicas e o fornecimento de recursos, são capazes de coibir a inclusão e a igualdade social, caso não seja realizado um planejamento comprometido de fato com o desenvolvimento sustentável. É, portanto, primordial que os novos projetos urbanos considerem durante sua elaboração aspectos socioambientais de resiliência por meio de estratégias inclusivas, para que seja possível garantir o desenvolvimento sustentável das cidades pelo aumento da capacidade adaptativa com a melhoria dos recursos humanos.

Lançado no dia 5 de junho de 2018, em Maceió (AL), o Glossário do Objetivo do Desenvolvimento Sustentável 11 para a Agenda 2030 tem como meta "tornar as cidades e os assentamentos humanos inclusivos, seguros, resilientes e sustentáveis”. O documento em questão serve como base para o debate de políticas públicas pela definição de referências e conceitos, deixando claras a relação e a importância do desenvolvimento sustentável como objetivo na elaboração dos projetos urbanos atuais.

O desgaste ideológico da reprodução projetual das cidades modernas colocou o urbanismo em um novo patamar de discussão. Atualmente, o entendimento do funcionamento das "cidades como máquinas” - com base no qual seria possível antever seu futuro em termos de desenvolvimento - passou a ser questionado, predominando a compreensão da cidade como um organismo complexo e mutável, de futuro incerto. Faz-se, portanto, necessário pensar o urbanismo de forma mais flexível, pela compreensão de que as cidades são sistemas complexos e mutáveis, sendo a prospecção de futuro fundamental para seu planejamento e devendo ser atualizada constantemente.

O crescimento urbano sem preocupação com a redução das desigualdades sociais pode proporcionar um processo de gentrificação decorrente da valorização de algumas áreas da cidade. Esse efeito é também outro fator que influencia a sustentabilidade urbana, visto que, ao afastar a população local para regiões mais

\footnotetext{
${ }^{1}$ ONU. UN-Habitat for a better urban future. Implementing the new urban agenda. 2016.
} 
distantes do Centro — que muitas vezes ainda não são dotadas de infraestrutura —, além de causar a diminuição da diversidade e da vitalidade urbanas, também proporciona o aumento, por exemplo, da necessidade de deslocamentos diários, aumentando, em consequência, a emissão de gases que produzem o efeito estufa.

De acordo com documento divulgado pela Prefeitura do Rio de Janeiro, o projeto do Porto Maravilha teria amplo potencial para atrair grandes empresas transnacionais e investimentos para a região. Juntamente com a obsolescência das estruturas que baseavam a atividade portuária na área, o projeto, então, legitima-se pela ideia de promover uma requalificação ou revitalização dos espaços, negando, portanto, a ideia de vida preexistente na região.

O projeto realizado para a região estudada (Figura 1) abrange uma área de aproximadamente 5 milhões de metros quadrados e foi implementado pela formação de uma parceria público-privada (PPP), que se viabilizou a partir da disponibilização de compra pelo mercado imobiliário de Certificados de Potencial Construtivo (Сepac), que possibilitam um acréscimo da área construída além do índice em locais determinados pelo plano.

O retorno financeiro previsto com a comercialização dos certificados seria, assim, responsável pelo financiamento dos recursos necessários para a execução das obras previstas. A inclusão do Porto Maravilha como um cluster olímpico, ${ }^{2}$ junto com o momento político vivido na época de sua concepção, possibilitou a união entre diversas esferas do governo e a inclusão de áreas que eram de propriedade tanto do município quanto do estado e da União no projeto realizado.

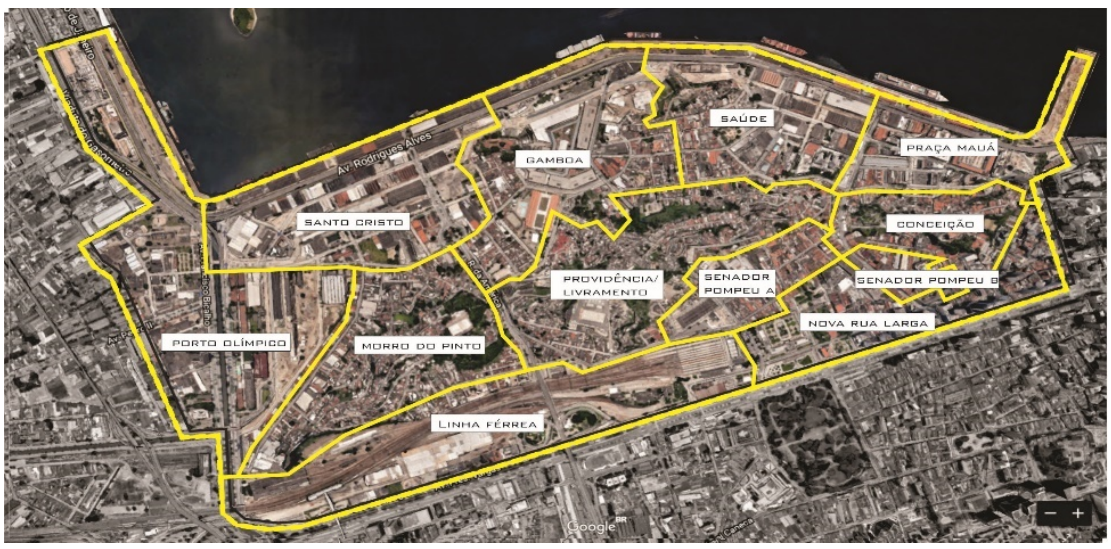

Figura 1 - Mapa do Porto Maravilha e sub-regiões propostas pelo projeto. Fonte: Elaboração própria.

\footnotetext{
${ }^{2}$ Rolnik define como cluster olímpico os projetos que tiveram maior visibilidade e destaque durante o período dos megaeventos.
} 
Até meados do século XVIII, a região do porto do Rio ainda não havia sido urbanizada. No local, existiam apenas alguns trapiches de sal, a Igreja de São Francisco, a Fortaleza da Conceição, o Palácio do Bispo e a cadeia de Alujipe, que era para onde eram enviados os escravos que cometessem algum crime. Com o intuito de afastar o comércio negreiro que se instalava no Centro da cidade, o então vice-rei marquês de Valongo destinou tais atividades para a região, que foi então nomeada como Cais do Valongo - e posteriormente chamado Cais da Imperatriz —, o qual atualmente faz parte do Circuito da Herança Africana e passou a ser considerado Patrimônio da Humanidade pela Unesco.

Foi a partir dessa época, então, que a região consolidou-se com a presença negra. Nesse local, eram desembarcados os navios e comercializados os escravos. Muitos deles já chegavam mortos pelas péssimas condições de viagem e eram enterrados ali mesmo, em covas baixas, no Cemitério dos Pretos Novos, onde atualmente é o Instituto dos Pretos Novos (IPN). Os que estavam convalescentes permaneciam em instalações como “a casa da engorda” até se recuperarem, enquanto os que tinham condições eram comercializados no mesmo local. Era também na região portuária (mais precisamente na Pedra do Sal) onde os escravos — principalmente os que trabalhavam no porto - reuniam-se e, na medida do possível, buscavam manter seus costumes e tradições, visto que as práticas de atividades de matriz africana eram proibidas na cidade nessa época.

Após a proibição da comercialização de escravos, a região passou a receber grandes galpões, que se tornaram os trapiches de café para exportação posteriormente, com a modernização do sistema portuário, esses galpões se tornariam obsoletos. Muitos escravos e ex-escravos passaram a ocupar a região, trabalhando principalmente nas atividades portuárias.

A região estudada passou por diversas reformas urbanas ao longo de sua história. Em 1870, o crescimento demográfico da cidade promoveu um aumento dos custos de moradia no local, o que acabou levando muitos de seus habitantes a se mudarem para outras áreas da cidade. Aqueles que tinham menor poder econômico viam-se obrigados a morar em cortiços e pensões pela proximidade do trabalho. Posteriormente à abolição da escravatura, muitos negros imigrantes que vinham para o Rio de Janeiro em busca de emprego também eram recebidos e acolhidos nesse local, onde também se reuniam e exerciam trocas culturais. 
Em 1957, com o intuito de desviar o trânsito da avenida Brasil para o Centro da cidade, foi iniciada uma obra que levaria 20 anos, passando por duas inaugurações em momentos distintos. A construção da Perimetral sobre a rodovia Rodrigues Alves, via responsável pelo abastecimento do porto e dos armazéns, que se conectava com a avenida Brasil, buscava atender a um modelo viário funcionalista (Izaga, 2017) proposto por Corbusier, dando origem ao rodoviarismo.

Com o tempo, a construção da Perimetral acabou perdendo o sentido. A rodovia elevada mantinha a Rodrigues Alves livre para o trânsito gerado pelo abastecimento dos armazéns localizados nos galpões ao longo da orla; no entanto, durante a década de 1970, diversos portos pelo mundo passaram por um processo de modernização, incluindo a substituição dos armazéns pelos contêineres para o processo de armazenamento de material. Tal fato acabou tornando obsoletos muitos dos galpões destinados a essa finalidade no porto do Rio e reduziu a necessidade de uma via destinada somente para esse fim na área portuária.

Diversos autores consideram a construção da Perimetral, somada à obsolescência da estrutura portuária, o principal fator que teria agravado a degradação da área. Já desde a década de 1970, foram desenvolvidos múltiplos projetos urbanos com o intuito de reverter essa situação de subutilização, por obsolescência, da área; no entanto, a impossibilidade de um acordo entre as esferas municipal, estadual e federal acabou dificultando a viabilização e a execução desses projetos (Figura 13).

Somente no século XXI esses obstáculos foram superados e, juntamente com a possibilidade da inclusão da área como um dos projetos olímpicos, o Porto Maravilha começou a ser implementado, em 2009, por meio de um consórcio, o qual foi intitulado Operação Urbana Consorciada da Área de Especial Interesse Urbanístico (AEIU) da Região Portuária do Rio de Janeiro. Pela Lei Municipal Complementar n⿳o 101/2009, ${ }^{3}$ foram definidos os gabaritos e os setores com o potencial de consumo dos Cepacs. O plano foi estabelecido um mês após o Rio de Janeiro ser eleito para sediar as Olimpíadas, quando o então prefeito Eduardo Paes encaminhou três projetos de lei, transformando em texto legal a modelagem apresentada pela OAS — uma das construtoras envolvidas que fazem parte do consórcio Porto Novo, formado para a implantação do projeto e que inclui também a participação das empresas Odebrecht 
e Carioca Engenharia. O plano desenvolvido para a região portuária foi então votado em regime de urgência na Câmara Municipal e incluiu o porto como um dos projetos olímpicos de referência (Rolnik, 2015).

A presente pesquisa parte do pressuposto de que os projetos urbanos devem considerar a participação popular e a aplicação justa e equitativa dos recursos para promover a diminuição das desigualdades. Dessa forma, conforme destacado pela fundamentação teórica, um projeto realizado sem considerar esses dois pontos fundamentais não seria capaz de garantir a sustentabilidade.

Primeiramente, serão abordados os ideais de sustentabilidade e desenvolvimento sustentável, tendo como base sua característica multidisciplinar de entendimento, passando brevemente pelo histórico da propagação do conceito e suas dimensões, contrapondo a ideia de desenvolvimento ligado ao crescimento econômico. Serão também abordados os aspectos de sustentabilidade urbana como caminho para superar a crise socioambiental e o futuro das cidades. A partir do referencial teórico específico sobre o tema e da metodologia desenvolvida durante a pesquisa, serão elaborados critérios que possibilitem a análise dos aspectos gerais de sustentabilidade urbana. Posteriormente, será feita a análise do estudo de caso, o Porto Maravilha, considerando os critérios elaborados pela metodologia. O trabalho considera ainda uma análise geral do contexto urbano com o qual o projeto foi desenvolvido para a cidade do Rio de Janeiro, bem como entrevistas, documentos e mapas elaborados ao longo da pesquisa apresentada. 


\section{2 \\ Sustentabilidade, desenvolvimento sustentável e sustentabilidade urbana}

\section{1. \\ A crise socioambiental e o futuro das cidades}

A maior parte da população do mundo vive em áreas urbanas, e a perspectiva de crescimento e adensamento das cidades só tende a aumentar. Segundo Dias (2013), as cidades ocupam apenas 2\% da superfície do planeta, mas utilizam 75\% dos recursos disponíveis. A ideia de desenvolvimento está muitas vezes associada aos processos de modernização e urbanização pelo domínio do homem por meio da tecnologia sobre a natureza. No entanto, ao mesmo tempo que a crescente urbanização remete a uma sensação de desenvolvimento, nota-se que o aumento exponencial das cidades têm ampliado a situação de vulnerabilidade, principalmente entre a população mais pobre, colocando em risco sua própria sobrevivência.

A cidade, de acordo com Orsi (2009), caracteriza-se tanto por ser o espaço no qual as transformações do ser humano sobre a natureza concretizam-se quanto pelas tensões existentes na disputa por esse espaço. Portanto, ainda segundo o autor, é possível verificar dois eixos de análise, que, apesar de estarem interligados, são frequentemente vistos de formas distintas: a estrutura físiconatural e a estrutura socioeconômica.

Enquanto a estrutura físico-natural diz respeito aos espaços e à sua materialidade, a estrutura socioeconômica está voltada para as interações culturais, econômicas e sociais que acontecem nesse espaço. As ações realizadas em determinado campo podem interferir diretamente em outras áreas, sendo, portanto, impossível desassociar a estrutura físico-natural da socioeconômica.

Para Fernandes \& Sampaio (2008), a crise atual da sustentabilidade como paradigma está associada tanto à relação entre o ser humano e a natureza quanto à ideia de progresso pela colonização. Para Kothari (1990), esse processo se dá a partir da colonização, por parte do ser humano, do futuro e da natureza, subjugando a ideia de evolução e cooperação entre os sistemas sociais e ambientais. Portanto, para que seja possível enfrentar a crise socioambiental em curso, é importante também compreender como os problemas socioeconômicos interferem na e 
articulam-se com a problemática ambiental, considerando os impactos antrópicos sobre a natureza gerados por esse processo de colonização.

Segundo diversos autores, como Maturana \& Varela (2001), a problemática ambiental apresenta uma pluralidade que ultrapassa a dualidade sociedade/natureza. Fernandes \& Sampaio (2008) também destacam que é necessário falar sobre a relação entre os homens entre si para compreender a origem desses problemas. Ainda de acordo com essa mesma ideia, para Horkheimer (2002), a forma como o ser humano subjuga a natureza é a mesma ao subjugar outro ser humano, sendo esse, portanto, outro aspecto das relações que deve ser considerado quando analisada a crise socioambiental.

Para Serres (2000), o que acontece com o planeta Terra e as relações entre os homens pode ser visto como dois lados de uma mesma moeda. Seus problemas têm, em sua origem, a racionalidade predominantemente econômica de nossa sociedade.

A própria noção de "recurso natural” para designar os elementos da natureza essenciais para a vida do ser humano pode ser entendida como um reflexo da visão do ser humano voltada para a economia (Fernandes \& Sampaio, 2008). Ao se utilizar a palavra recurso, também acaba sendo reforçada a ideia de que elementos da natureza poderiam ser qualificados como bens ou riquezas, dando-lhe um valor financeiro. É importante, segundo Fernandes \& Sampaio (2008), ressignificar o termo, destacando que seu valor ultrapassa os valores financeiros. Sánchez (2013) define como recurso ambiental a capacidade do ambiente de dar suporte à continuidade da vida pelo fornecimento de recursos físicos necessários. A degradação ambiental, portanto, empobrece o meio ambiente, restringindo os recursos necessários para a manutenção de todas as formas de vida (Cunha et al., 2013).

A crise ambiental, segundo Dansereau (1999), apresenta ainda uma dimensão moral, que pode ser compreendida pela prospecção ecológica. Para o autor, a raiz dos problemas atuais é simultaneamente a causa e a consequência da crise de valores, na qual predomina uma visão fragmentada, baseada no dualismo e na dicotomia da sociedade. De acordo com Fernandes \& Sampaio (2008), a prescrição moral não resulta de uma prescrição ecológica, e esse é o principal motivo de vivermos riscos que podem ser irreversíveis futuramente, criando ainda uma crise de consciência pelos impactos na natureza gerados pela ação antrópica (Morin \& Kern, 1995).

Portanto, a conotação ecológica da crise ambiental é apenas uma variável das múltiplas crises vividas por nossa sociedade (Orsi, 2009). Para que seja possível ter 
uma compreensão mais ampla da crise, devemos compreendê-la como um fenômeno multifacetado, em que os vários ângulos estão simultaneamente abalados. Ainda segundo o autor, alguns pontos básicos, como aspectos sociais, ecológicos, políticos, tecnológicos, econômicos e ideológicos/culturais, devem fazer parte do debate a respeito da crise socioambiental. Orsi (2009) destaca como exemplo os seguintes aspectos: social - está fundamentado na degradação do meio ambiente pela produção de bens das classes mais ricas, pelas desigualdades, pela pobreza e pela fragilização das relações sociais; ecológico - uso dos recursos naturais de forma insustentável em razão de sua finitude; político - destaca a crise de legitimidade do Estado e sua importância para fornecer serviços necessários para a população; tecnológico - o avanço da tecnologia pode gerar melhoria da qualidade de vida das pessoas, no entanto sua distribuição acontece de forma desigual, além de incorrer em riscos que promovem a degradação da natureza; econômico ressalta o modelo de exclusão e competição dos territórios em busca do aumento de investimento, bem como a atribuição de valor aos recursos naturais; ideológicos/culturais - destaca o modelo vivido pela sociedade contemporânea, baseado no consumo e no individualismo, estando relacionado com diversos aspectos da crise socioambiental.

O enfrentamento da crise socioambiental tem caráter multidimensional. Os riscos associados a ela podem ter origem natural ou antrópica e apresentam, segundo Mendonça (2011), três formas de manifestação, que podem surgir de maneira associada, sendo elas: natural, tecnológica e social. A distribuição desigual dos recursos, que pode aumentar a situação de vulnerabilidade pela desigualdade e pela pobreza; a degradação do meio ambiente, que ocasiona a perda da biodiversidade; a mudança climática, agravada pelas emissões de gases do efeito estufa, que podem aumentar a ocorrência de eventos naturais, como elevação do nível do mar, da formação de ilhas de calor, de alagamentos e tempestades; bem como a poluição do ar, que interfere diretamente na saúde da população e na formação da chuva ácida, prejudicando diretamente a produção de alimentos, são exemplos de características presentes no modelo de urbanização crescente atual que compõem a crise socioambiental e podem inclusive agravá-la, afetando as mais diversas formas de vida em todo o planeta.

Assim, os riscos e as ameaças aos quais as cidades estão expostas na crise socioambiental podem ser tanto naturais quanto antrópicos. A presença do ser 
humano interfere diretamente no meio ambiente, e o impacto de suas ações muitas vezes pode colocar em risco sua própria sobrevivência.

Autores como Veyret (2007) e Dubois-Maury \& Chaline (2002) entendem que o risco pode ser de três tipos, que muitas vezes se somam e interagem entre si, sendo eles os riscos naturais, sociais e tecnológicos. De acordo com Mendonça (2004), os riscos devem levar em conta as vulnerabilidades urbanas socioambientais, pois estas podem gerar ou aumentar sua gravidade. Ainda segundo o autor, um dos pontos de maior complexidade tem a ver com sua relação com o espaço e tempo (Mendonça, 2004). Os riscos devem considerar a localidade e o cenário futuro, ultrapassando o ponto de vista apenas social e ambiental, levandose ainda em conta que alguns riscos processam-se no tempo futuro e acabam tornando-se de difícil percepção, caso não haja o devido envolvimento e interesse da sociedade (Mendonça, 2004).

A dificuldade em aplicar medidas efetivas para a preservação do meio ambiente e da vida humana na Terra, como no caso da luta contra o aquecimento global, pode ser relacionada com o paradoxo de Giddens e com o que os psicólogos chamam “desconto do futuro” como seu acentuador. O paradoxo, que leva o mesmo nome de seu autor, está associado à dificuldade de perceber os riscos ambientais, visto que as consequências não são palpáveis ou visíveis no cotidiano, e, quando seus efeitos tornam-se visíveis, já pode ser “tarde demais”. Assim, muitas vezes a sociedade acaba aceitando um risco ambiental em troca de uma recompensa oferecida no momento.

Segundo Beck (1992), os maiores riscos que afetam a sociedade contemporânea são, na maioria, reflexo do próprio ser humano no planeta (apud Porto-Gonçalves, 2016). Não seria possível responsabilizar diretamente nenhum agente causador dos riscos, que não é possível conter de forma espacial ou temporal e provocam um futuro incerto e individualista. Os riscos e as desigualdades globais, ainda segundo o autor (Beck, 2008), derivam em vulnerabilidades locais e reforçam o peso do conhecimento e da intervenção no futuro.

De acordo com Trajano (2010), o princípio da precaução ${ }^{4}$ deve ser usado como ferramenta diante da presença de alguma ameaça futura. O autor orienta que sua aplicação deve sempre levar em conta o cenário mais desfavorável, quando

\footnotetext{
${ }^{4}$ O princípio da precaução surgiu como fruto do princípio número 15 da Declaração do Rio, formulada na Conferência Rio-92.
} 
houver alguma evidência de um ecossistema frágil ou ameaçado, visto que não é possível identificar o limite de resiliência da natureza e a importância de preservar o meio ambiente para salvar as vidas das gerações atuais e futuras.

Hans Jonas apresenta o pensamento ético antropocêntrico, que surge apenas dos problemas originados do "aqui e agora”, por meio do "princípio da responsabilidade”. Em sua obra The imperative of responsibility (1979), o filósofo alemão não só ressalta a importância da ética para com as gerações futuras, como também destaca a natureza como responsabilidade do ser humano. Segundo o autor, o progresso civilizatório caminha de mãos dadas com a depredação da natureza. Por meio do imperativo "Aja de modo a que os efeitos de tua ação sejam compatíveis com a permanência de uma autêntica vida humana sobre a Terra” (Jonas, 2006), o autor agrega ao pensamento ético a preocupação com o meio ambiente, propondo limites à sua violação como uma necessidade, a fim de assegurar a continuação da vida humana no tempo em face do desenvolvimento tecnológico e da ideia de progresso associada ao crescimento a qualquer custo.

A visão ética proposta por Hans Jonas (2006) dialoga diretamente com a condição humana da atualidade e a insustentabilidade do modelo de vida baseado no consumo. O surgimento do "homo faber" - que tinha como ideal sua permanência e duração, produzindo os instrumentos para facilitar suas atividades — e a posterior vitória do “animal laborans" — que visava à abundância e, pelo trabalho, seria capaz de atingir o crescimento e o acúmulo, tornando o ser humano uma ferramenta do próprio trabalho — reduziram as atividades humanas à condição de assegurar as coisas necessárias à vida e de produzi-las em abundância (Arendt, 2005), fazendo com que o ser humano consumisse os bens produzidos da mesma forma como consome os alimentos necessários para seu funcionamento metabólico e sua sobrevivência.

Segundo o relatório “A Economia dos Ecossistemas e da Biodiversidade para Formuladores de Políticas Locais e Regionais” (TEEB, 2010), as cidades são responsáveis por consumir 70\% dos recursos disponíveis no planeta. Leite (2012, p. 14) afirma que é pela atuação nas cidades que será possível encontrar um futuro sustentável, visto que elas são as maiores consumidoras dos recursos naturais e geram mais resíduos.

A reprodução de um modelo urbano a partir de grandes operações muitas vezes apropria-se do discurso da sustentabilidade, da "revitalização" e da "requalificação", frequentemente pouco dialogando com as reais necessidades da população existente, 
bem como com suas características de identidade e cultura (Sánchez, 2009). Diversos projetos realizados pelo mundo, como é o caso de Bilbao e Barcelona, por exemplo (Arantes, 2000), utilizam-se da produção de elementos simbólicos capazes de proporcionar maior valor competitivo para a venda da cidade (Sánchez, 2009), os quais afirmam a transformação da cidade em mercadoria. A reprodução de projetos urbanos que priorizam obras monumentais em detrimento do atendimento das necessidades da população muitas vezes acaba tornando os espaços ainda mais insustentáveis, visto que a valorização imobiliária sem diminuição da desigualdade e distribuição equitativa dos recursos pode também proporcionar um processo de gentrificação, fortalecendo as desigualdades sociais, podendo também provocar impactos ambientais, como o aumento da emissão de gases provenientes do fluxo casa-trabalho com o distanciamento da população dos centros urbanos.

Segundo Carvalho (2000), a origem do conceito de cidade global está relacionada com os impactos da globalização nas metrópoles do Primeiro Mundo. Esse conceito passou a ser mais discutido a partir do final da década de 1970. Sassen (1998) designou, inicialmente, como cidade global aquelas que atuavam como pontos nos quais ocorriam os fluxos financeiros responsáveis pelo controle do mercado de títulos e ações; assim, depois a expressão passou a ser apropriada para denominar uma nova ordem urbana (Compans, 2011). Como resultado da crise fiscal, da desindustrialização e da terceirização da cidade, ocorre uma mudança no perfil das metrópoles (Sassen, 1998), e áreas que até então eram desvalorizadas e negligenciadas pelo poder público, em sua maioria tradicionalmente operárias, passam a ganhar mais atenção do mercado como sendo áreas potenciais econômicas e atrativas para sediar empresas altamente especializadas de prestação de serviços, em sua maioria transnacionais ligadas ao setor financeiro e da comunicação.

É dentro desse contexto que grandes operações urbanas muitas vezes acabam legitimando-se, com o objetivo de aumentar a eficiência das cidades, diminuindo os vazios urbanos centrais formados pela obsolescência dos espaços. De acordo com esse discurso, tornar as áreas já dotadas de infraestrutura e mais próximas ao Centro capazes de absorver a crescente demanda por espaço pode ajudar a tornar as cidades mais sustentáveis, diminuindo seu impacto no meio ambiente.

Em razão da proximidade com o centro empresarial e da obsolescência da estrutura portuária, diversos projetos foram apresentados ao longo dos anos, com o intuito de habitar a região. No entanto, a dificuldade de firmar uma parceria entre 
as diversas esferas do governo dificultou sua implantação. A escolha do Rio de Janeiro para sediar os Jogos Olímpicos estimulou o investimento em diversos projetos pela cidade, entre eles o Porto Maravilha, que, inicialmente, não havia sido incluído no programa, mas foi depois apresentado com um potencial cluster olímpico (Rolnik, 2015).

Para que fosse possível viabilizar sua implantação, foi formada uma parceria entre município, estado e União e uma parceria público-privada (PPP), pela Lei Municipal nº 101/2009, a qual possibilitou a aquisição de Cepacs pelas empresas privadas que tivessem interesse em construir nas áreas determinadas pelo projeto.

A aplicação de modelos urbanos voltados principalmente para a financeirização e a valorização econômica dos espaços pode colocar em risco sua própria sobrevivência, caso eles não estejam também comprometidos com políticas de sustentabilidade mais abrangentes, que incluam processos participativos com distribuição dos recursos, valorização da cultura e diminuição da desigualdade. Existem diversos tipos de sustentabilidade (Lemos, 2010), que variam de acordo com as necessidades e as características locais, bem como de acordo com o espaço e tempo.

Considerando que o desenvolvimento sustentável vai além do crescimento econômico e levando ainda em conta que cada sociedade tem uma realidade única, que varia de acordo com o espaço e tempo, entende-se como um dos elementos do desenvolvimento sustentável a melhoria do bem-estar social, com garantia da liberdade de escolha das pessoas e distribuição justa e equitativa de oportunidades. Tendo em vista que o desenvolvimento deve considerar o que cada indivíduo desta e das futuras gerações - entende como sustentabilidade e a diminuição das desigualdades, é possível identificar que entre os elementos fundamentais da sustentabilidade está a diminuição das desigualdades, bem como o processo participativo na tomada de decisões e o fortalecimento da identidade e da cultura, tornando-se impossível dissociar os aspectos sociais e os aspectos ecológicos para o enfrentamento da atual crise socioambiental. 


\section{2.}

\section{Sustentabilidade e desenvolvimento sustentável}

A noção de sustentabilidade começou a ser amplamente discutida pelo mundo a partir da década de 1970, quando os movimentos ambientais ganharam mais força na luta pela preservação e manutenção dos recursos naturais.

Em 1968, um grupo de políticos, empresários e cientistas preocupados com o crescimento desenfreado das cidades e suas possíveis consequências reuniu-se, fundando o Clube de Roma, no qual se comprometiam a conscientizar personalidades, políticos e líderes internacionais a respeito da importância da preservação do meio ambiente. O Relatório Meadows, encomendado pelo grupo, intitulado “Os limites do crescimento”, fez uma análise da interação do ser humano com a natureza, considerando o aumento populacional e o esgotamento de recursos naturais, identificando ainda que, caso a sociedade continuasse consumindo os recursos como naquela época, eles se esgotariam rapidamente. No mesmo ano que o relatório foi encomendado, em 1972, foi realizada a Conferência das Nações Unidas pelo Meio Ambiente Humano, também conhecida como Conferência de Estocolmo, na Suécia, tornando-se um marco histórico sobre o tema por ter sido a primeira grande conferência internacional na qual agentes de diversas nações comprometeram-se com as causas ecológicas. A ideia de desenvolvimento sustentável e as diretrizes propostas difundidas mundialmente nessa época posteriormente tornaram-se peças fundamentais nas agendas e políticas públicas das mais diversas nações em todo o mundo.

Em 1987, 15 anos após a Conferência de Estocolmo, foi publicado pela Organização das Nações Unidas (ONU) o documento “Nosso futuro comum”, mais conhecido como Relatório Brundtland, nome da então primeira-ministra da Noruega que no período chefiou a Comissão Mundial sobre Meio Ambiente e Desenvolvimento. O documento “Nosso futuro comum” definiu o desenvolvimento sustentável como “o desenvolvimento que atende às necessidades do presente, sem comprometer a possibilidade das gerações futuras atenderem suas próprias necessidades” (Brundtland, 1987).

O mesmo relatório fundamenta o desenvolvimento sustentável como um processo de transformação que reforça o potencial presente, harmonizando a exploração de recursos com desenvolvimento tecnológico, investimentos, 
mudanças institucionais e orientações, a fim de atender às necessidades e aspirações humanas (Brundtland, 1987).

Outro importante marco histórico da noção de sustentabilidade ocorreu cinco anos depois, quando uma nova Conferência do Meio Ambiente de amplitude mundial foi realizada, dessa vez no Brasil, mais precisamente no Rio de Janeiro a Rio-92, ou Eco-92 —, na qual não só foi reafirmada a importância do debate sobre o tema em uma escala global, como também foram evidenciados novos desafios e diretrizes, os quais serviram de base para a elaboração de textos como a Agenda 21 e a Carta da Terra, retificada pela Unesco e aprovada pela ONU em 2002. A Carta da Terra ressalta que, em meio a um mundo que enfrenta grandes perigos e tornase cada vez mais frágil, devemos reconhecer que entre diversas formas de vida e cultura temos um destino comum, e, ao assumirmos nossa responsabilidade ética com as gerações atuais e futuras, devemos nos unir para construir uma sociedade “sustentável global baseada no respeito pela natureza, nos direitos humanos universais, na justiça econômica e numa cultura de paz” (A Carta da Terra, 2002).

O conceito de ecodesenvolvimento, muitas vezes associado a um padrão de desenvolvimento sustentável, foi introduzido por Maurice Strong, secretário da Conferência de Estocolmo, e, posteriormente, popularizado por Ignacy Sachs (Godard, 1991) em todo o mundo, principalmente no Brasil. Além de aproximar o tema da sustentabilidade das políticas econômicas, o autor reafirma a responsabilidade com as gerações futuras, já destacada pelo Relatório de Brundtland, ao ressaltar que se, por um lado, devemos buscar o desenvolvimento de forma que seja possível garantir a melhoria de vida e das capacidades individuais das pessoas, por outro devemos ainda assegurar que os recursos naturais necessários para as próximas gerações possam garantir seu próprio desenvolvimento do modo que for compreendido por elas (Sachs, 2008).

Entretanto, é a partir das ideias aparentemente contraditórias entre sustentabilidade e desenvolvimento que se encontra a principal dicotomia da expressão desenvolvimento sustentável. Segundo Mészaros (2001), o “desenvolvimento” já é por si só, segundo uma lógica capitalista, insustentável, sendo, portanto, impossível garantir a sustentabilidade sem reduzir as desigualdades substantivas, superando o modelo de produção hegemônico e suas dificuldades estruturais. O próprio significado da palavra “desenvolver”, segundo o autor PortoGonçalves, ressalta a dicotomia do termo e sua complexidade: 
[...] tirar o envolvimento (autonomia) que cada cultura e cada povo mantém com seu espaço, com seu território; subverter o modo como cada povo mantém suas próprias relações de homens entre si e destes com a natureza; não só separar os homens da natureza como, também, separá-los entre si, individualizando-os. (Porto Gonçalves, 2006, p. 81).

O paradoxo do desenvolvimento sustentável reafirma-se na dicotomia de sua etimologia. Ao mesmo tempo que "sustentabilidade” sugere equilíbrio e conservação, o termo “desenvolvimento" sugere dinamismo e mudança, dividindo, portanto, seu ponto de atenção. Ambientalistas, mais preocupados com a preservação do meio ambiente, ao abordar o desenvolvimento sustentável, acabam focando o aspecto da sustentabilidade ecológica, enquanto as empresas e políticas focam o ângulo do "desenvolvimento", na maioria das vezes associado apenas ao crescimento econômico, ao aumento do produto interno bruto (PIB) e ao acúmulo de bens.

Um dos grandes desafios da sociedade atual é justamente encontrar um modo de desenvolver e de se sustentar de forma simultânea. Portanto, o entendimento sobre desenvolvimento atrelado ao crescimento e ao acúmulo de bens a todo custo deve ser ressignificado, sendo substituído por um entendimento mais humano, segundo o qual o bem-estar e a liberdade sejam considerados de forma integrada com o respeito e a preservação dos sistemas naturais, bem como com o compromisso ético para com as gerações futuras e atuais. Devemos repensar a ideia de desenvolvimento, que muitas vezes é aplicado como sinônimo de velocidade e crescimento e que "des-envolve”, ou seja, tira o envolvimento, ressignificando-o de forma que seja possível incluir critérios de bem-estar e qualidade de vida, considerando que existem vários tipos de sustentabilidade, de acordo com cada realidade.

Tendo em vista os interesses distintos e muitas vezes divergentes entre os diversos campos de aplicação, o conceito de desenvolvimento sustentável é bastante amplo em sua concepção e abrangência. Torna-se de difícil aplicação consensual e é entendido por muitos como utópico, refutando-se, muitas vezes, a ideia da sustentabilidade como um fim possível de ser atingido, como um norte a ser alcançado, e o desenvolvimento sustentável como um processo a ser seguido, levando-se em conta sua multidisciplinaridade.

Economistas como Michael Kalecki e Dudley Seers, que, a partir de meados dos anos 1960, identificaram a importância de considerar o desenvolvimento além do PIB, também destacaram a necessidade da geração de empregos, da redução da pobreza e das desigualdades como critérios. Tais questões destacam a ineficiência 
de análise do PIB como ferramenta única de análise do bem-estar e do desenvolvimento, apesar de sua facilidade de cálculo em comparação aos demais indicadores. Crescimento econômico acelerado não é garantia de distribuição equitativa de renda e pode, pelo contrário, inclusive agravar as desigualdades, visto que a concentração de renda muitas vezes está restrita a um pequeno arquipélago social, enquanto a maior parte da população permanece à margem, lutando para garantir sua sobrevivência (Sachs, 2008).

Como alternativa ao PIB como ferramenta de análise do desenvolvimento e do bem-estar social, foram criadas outras metodologias de parametrização, como o Índice de Progresso Genuíno (IPG), lançado em 1995, cujas características são em boa parte semelhantes às do PIB, diferenciando-se, no entanto, por incluir fatores como distribuição de renda, valores do trabalho doméstico e do trabalho voluntário, criminalidade e poluição, por exemplo. Pode-se perceber, a partir dos resultados obtidos por pesquisas, que a evolução do IPG per capita ao longo dos anos muitas vezes não é proporcional ao crescimento do PIB no mesmo período (The Genuine Progress Indicator, 2006, p. 19, Figura 3).

Outros dois indicadores alternativos, que mostram parâmetros à luz do desenvolvimento, são o Índice de Bem-Estar Econômico Sustentável (Ibes), que utiliza dados locais e suas tendências, e o Î́ndice de Sociedade Sustentável (ISS). Criado em 2006, o ISS dá mais atenção aos aspectos ambientais, como a depleção de recursos naturais, que afeta áreas alagadiças, florestas, áreas agrícolas e matérias-primas não renováveis, os níveis de emissão de carbono, os materiais redutores de carbono, entre outros. O ISS também foca os aspectos sociais, como a distribuição de renda, o nível de trabalho voluntário e a dependência de ativos estrangeiros (Giddens, 2010).

A Cúpula Mundial de Desenvolvimento Social, realizada entre os dias 6 e 12 de março de 1995, na cidade de Copenhague (Dinamarca), foi outro marco histórico na conceituação do desenvolvimento, pois pela primeira vez discutiu-se o conceito de “desenvolvimento social”, além de elaborar metas definidas e um plano de ação de apoio aos países menos desenvolvidos para diminuição das desigualdades, da fome e da pobreza extrema.

Giddens (2010) destaca que a expansão populacional é uma das causas que hoje vêm ameaçando os recursos naturais, tendo estreita associação com a pobreza. Portanto, conclui o autor, enquanto os países mais pobres não atingirem certo 
padrão de riqueza, o planeta continuará apresentando dois caminhos de desenvolvimento distintos.

O aumento populacional e o crescimento sem planejamento têm forte relação com o aumento das desigualdades sociais, econômicas e territoriais, principalmente no meio urbano. Ao se destacar a importância do desenvolvimento sustentável, fazse necessário demonstrar que as restrições impostas para preservação do meio ambiente têm impacto maior nos países que ainda estão em processo de industrialização e que, por apresentarem maiores níveis de desigualdade, também estão mais vulneráveis a possíveis choques ambientais ou antrópicos. Para que se torne sustentável, o planejamento urbano deve considerar como critério a distribuição justa dos recursos para redução das desigualdades e vulnerabilidades, com melhoria da qualidade de vida de seus habitantes.

Cerca de $80 \%$ da matéria-prima e energia produzidas por ano são consumidos por apenas 20\% dos habitantes mais ricos do mundo (Porto-Gonçalves, 2016), demonstrando a má distribuição dos recursos. Seria então necessário, segundo Porto-Gonçalves, dispor dos recursos de cinco planetas para que os mais pobres pudessem desfrutar do mesmo padrão de vida dos mais ricos.

O desenvolvimento sustentável, portanto, não deve estar atrelado unicamente ao crescimento econômico. Ao contrário, a distribuição desigual dos recursos pode gerar ainda mais desigualdade e pobreza, agravando a situação de vulnerabilidade de boa parte da população. A melhoria das condições de bem-estar social e diminuição das desigualdades são elementos fundamentais para a promoção do desenvolvimento sustentável, pois sem eles, mesmo que haja crescimento econômico expressivo, este ficará restrito a um pequeno número de pessoas, enquanto a maioria permanecerá à margem, lutando para sobreviver (Sachs, 2008).

Visto que o crescimento acelerado das cidades reproduz um modelo insustentável de urbanização, faz-se, portanto, necessário entender a importância do desenvolvimento sustentável como ferramenta primordial para a elaboração de projetos urbanos mais inclusivos e sustentáveis, que garantam a duração e a sobrevivência das cidades, promovendo um aumento da qualidade de vida e do bem-estar desta e das futuras gerações. 


\section{3.}

\section{Sustentabilidade urbana}

Controlar os impactos e as tensões gerados e agravados pelo crescimento e pelo adensamento dos espaços urbanos é um dos maiores desafios da atualidade. Segundo o relatório “The 2018 world urbanization prospects”, produzido pelo Department of Economic and Social Affairs (UN DESA), até 2050 cerca de 68\% da população viverão em áreas urbanas, aumentando-se também o número de metrópoles. Surgirão mais 43, que se somarão às 33 existentes atualmente no mundo.

A ideia de desenvolvimento é constantemente relacionada com a dominação do ser humano sobre a natureza (Kothari, 1990) e tem como reflexo a priorização dos espaços urbanos e o crescimento das cidades. Sendo elas as grandes consumidoras dos recursos naturais e produtoras de rejeitos no meio ambiente, fazse fundamental, portanto, a construção de cidades mais sustentáveis, a fim de assegurar sua sobrevivência.

Segundo Douglas (2013), o urbanismo sustentável deriva de três movimentos do final do século XX: o novo urbanismo, o urbanismo inteligente e as construções sustentáveis. Ainda de acordo com o autor, apesar de terem em comum a valorização da integração entre sistemas humanos e naturais, esses movimentos apresentam abordagens distintas e uma visão pouco integrada. Para Douglas, o urbanismo sustentável diferencia-se por unir os três movimentos.

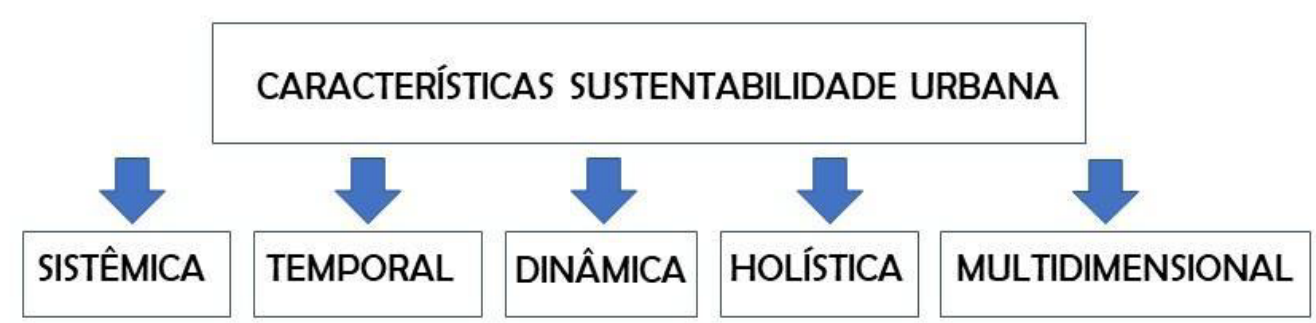

Figura 2 - Características da sustentabilidade urbana.

- Característica sistêmica: para melhor compreensão da sustentabilidade, deve-se observar o todo a partir das partes que o constituem.

- Característica temporal: as mudanças culturais, sociais, econômicas e tecnológicas interferem diretamente na ideia de sustentabilidade e nas necessidades de cada local. 
- Característica dinâmica: existem diversos tipos possíveis de sustentabilidade, de acordo com cada espaço e tempo, e as noções do tema vão variar junto com eles ou com a ocorrência de algum evento. É necessário que a ideia de sustentabilidade seja sempre revista e atualizada.

- Característica holística: deve-se ter uma concepção geral e uma visão do todo para a compreensão da sustentabilidade e dos efeitos das ações no meio ambiente.

- Característica multidimensional: a sustentabilidade tem múltiplas dimensões, que interagem entre si e devem ser relacionadas de forma conjunta.

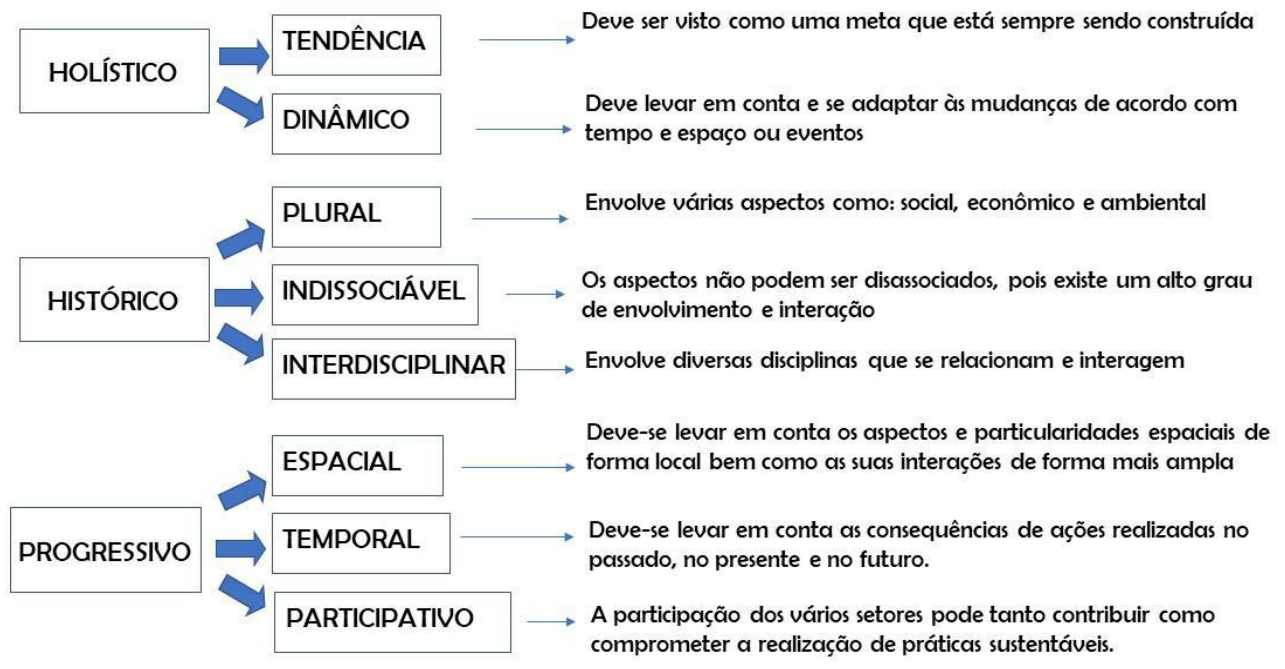

Figura 3 - Características da sustentabilidade. Fonte: Adaptado de Silva (2000).

As diversas categorias da sustentabilidade destacadas pela bibliografia abordada indicam forte relação entre os aspectos ecológicos e sociais. Cada lugar apresentará características próprias, que vão variar, sendo, portanto, impossível definir uma fórmula única capaz de tornar os espaços sustentáveis. A presente pesquisa parte da compreensão de que a sustentabilidade deve ser dinâmica (com capacidade de se adaptar às mudanças necessárias), temporal (levando-se em conta que o contexto influencia diretamente seu entendimento e as consequências de ações do passado e para o futuro), espacial (considerando-se que cada lugar tem particularidades e necessidades próprias, que variam em sua interação), participativa (deve contar com a participação de vários setores da sociedade), 
multidimensional (todas as dimensões relacionam-se) e plural (envolve aspectos sociais, econômicos e ecológicos).

Segundo Porto-Gonçalves (2006), espaço e sociedade devem ser vistos de forma indissociável, visto que se consolidam em território concreto. A dimensão temporal de espaço pode ser identificada na cidade pelas múltiplas escalas de tempo, que convivem de forma simultânea, seja pela materialidade dos elementos construídos - ruas, praças, monumentos —, seja pela perpetuação de características sociais e culturais, como hábitos e valores. Além de temporal, o espaço urbano tem ainda uma característica dinâmica, visto que é suscetível o tempo todo a mudanças que acontecem fora de seu controle.

Não é possível dissociar o espaço geográfico do tempo. De acordo com Milton Santos (1978), um novo modelo de produção e de relações pode estabelecerse em determinado lugar; no entanto, ele precisa adaptar-se de acordo com os modelos e objetos geográficos preexistentes. As marcas físicas desse encontro temporal são as rugosidades, termo que remete à metáfora das formações geológicas, as quais retratam um passado que permitiu a vida atual, atuando como um traço de união entre o passado e o presente. O espaço, ainda segundo Santos (1978), é privilegiado, pois cristaliza o passado e torna-se o lugar onde passado e futuro encontram-se, de acordo com as relações sociais que ali se configuram.

Leite (2012) defende que a cidade sustentável é a cidade compacta e densa. Por meio desse adensamento, seria possível ter menor consumo de energia per capita e otimizar a infraestrutura urbana. Ainda segundo o autor, a cidade densa também poderia restringir o espraiamento das áreas urbanas, que interferem nas áreas rurais. Por esse motivo, ele defende o incentivo da “reciclagem” (Leite, 2012, p. 13) do território nas áreas centrais, reaproveitando vazios urbanos com gestão eficiente, atividades econômicas voltadas para informação e comunicação, atividades vinculadas à vocação do lugar e criando novos valores locacionais melhores que sua substituição. O projeto, nomeado de Nova Economia Climática (NCE), foi encomendado por 28 líderes empresariais e afirma que as cidades compactas são mais resilientes, inclusivas, limpas, seguras, tendo ainda menor taxa de emissão de gases de efeito estufa (Zenghelis \& Stern, 2018).

A relação entre a infraestrutura necessária e a densidade populacional é demonstrada, segundo Nobre (2004), por uma parábola, na qual o ponto de melhor proporção está em torno de mil habitantes por hectare. Uma densidade muito baixa 
pode inviabilizar a instalação de serviços e equipamentos de infraestrutura pelo alto custo de instalação, enquanto uma densidade mais alta pode gerar diversos impactos ambientais, econômicos e sociais.

Assim, se, por um lado, o adensamento dos centros urbanos pode ser bom para o meio ambiente, por tornar os espaços mais eficientes e gerar menor impacto, por outro também pode inviabilizar a aplicação de medidas mais sustentáveis. O adensamento das cidades apresenta vantagens e desvantagens para o ambiente urbano, seja pelo alto custo de investimento em infraestrutura, seja pelos impactos sociais gerados, como distribuição desigual dos recursos, falta de qualidade do ar, formação de ilhas de calor e violência.

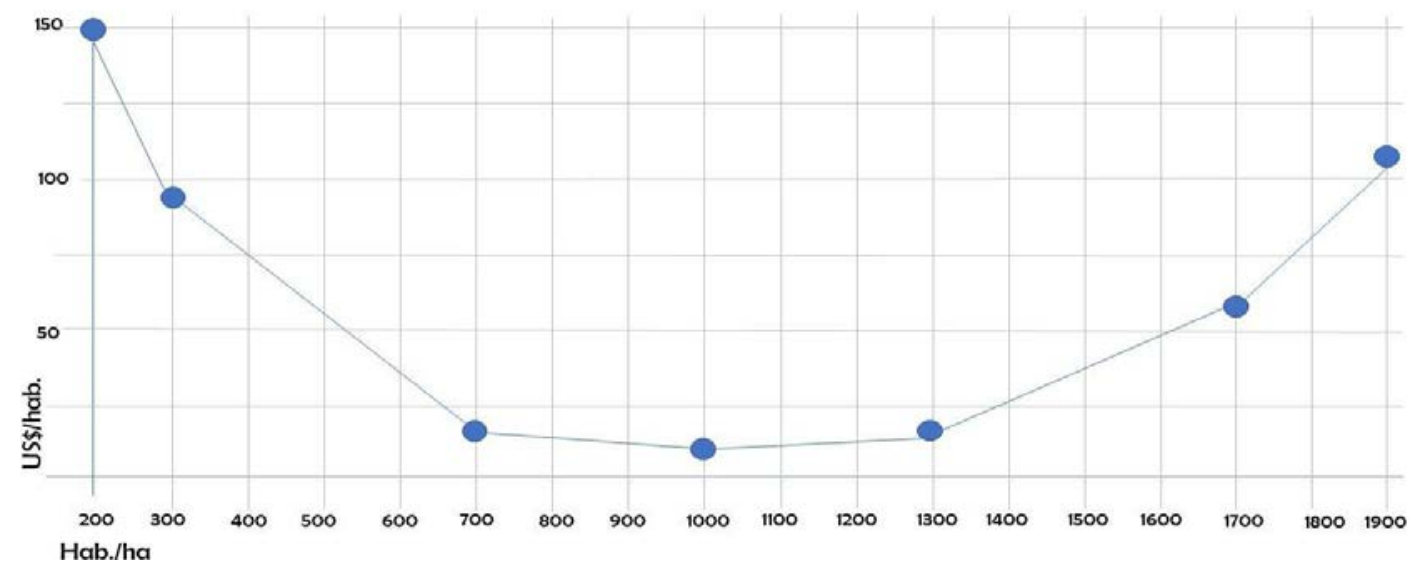

Figura 4 - Relação entre custo de infraestrutura e densidade. Fonte: Adaptado de Ferrari (1979, p. 350).

Lemos (2010) destaca que nem sempre a solução compacta é a mais sustentável. Em lugares com clima quente-úmido, por exemplo, tecidos menos compactados podem apresentar resultados mais sustentáveis, mesmo considerando o gasto ambiental com deslocamento, pois permitem a ventilação necessária para a saúde e o conforto térmico dos habitantes, evitando o gasto energético para melhorar a temperatura do ambiente.

Outro ponto que deve ser levado em consideração é que cada lugar terá uma noção diferente do espaço necessário e do adensamento ideal. Acioly \& Davidson (1998) ressaltam a importância de considerar o viés cultural e mencionam ainda Jacobs (1961 apud Silva, 2000), que aborda a densidade por uma metáfora com calorias e vitaminas, visto que o que é melhor pode variar de acordo com a especificidade do lugar. 
Pergunte a um planejador indiano o que é que ele pensa a respeito de um lote de $100 \mathrm{~m}^{2}$ para famílias de baixa renda e ele responderá que esse tamanho de lote é demasiadamente grande, portanto, inacessível financeiramente. Seu colega da África Oriental ou Cone Sul da África, entretanto, argumentará que esse tamanho é demasiadamente pequeno e inaceitável por parte da população. (Acioly \& Davidson, 1998, p. 15).

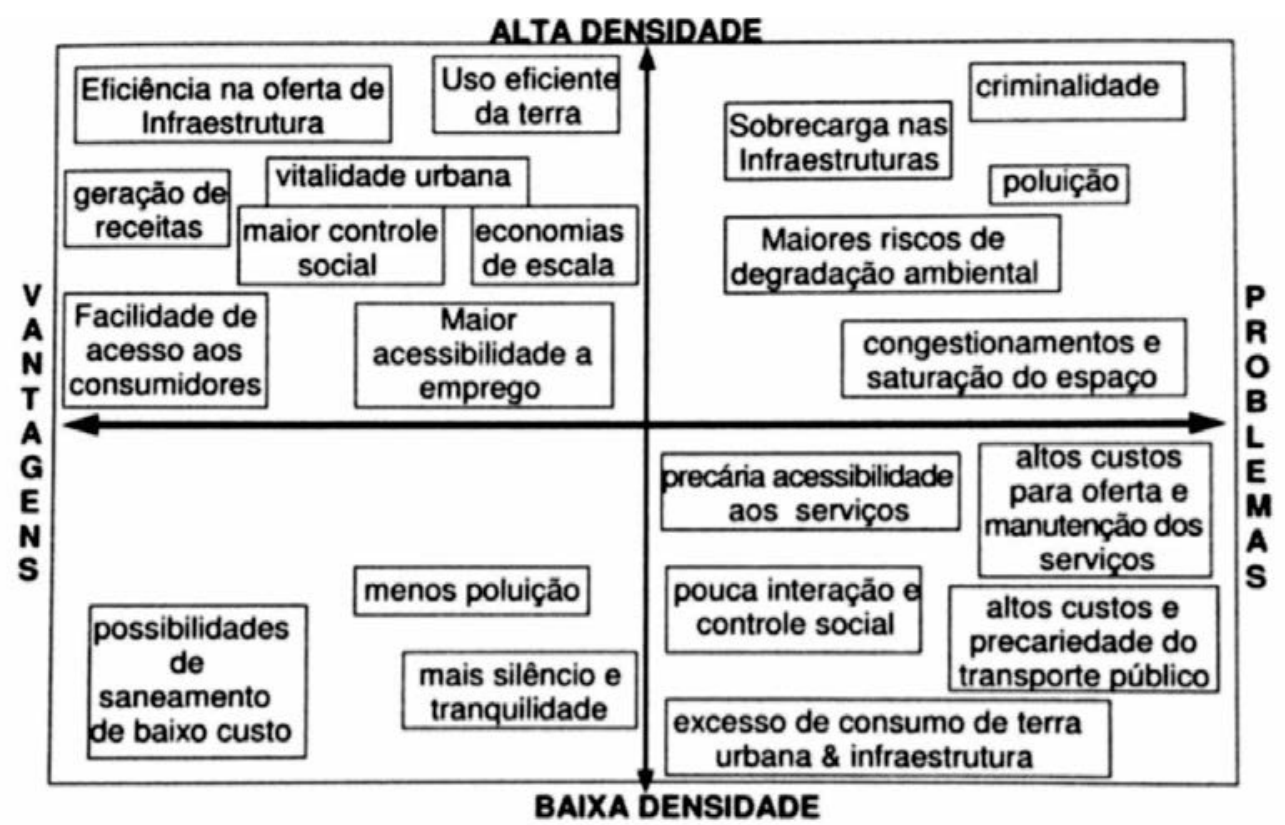

Figura 5 - Vantagens versus desvantagens de acordo com a densidade. Fonte: Acioly \& Davidson (1998).

O crescimento populacional exacerbado pode ainda ser um grande fator de ampliação das desigualdades, principalmente nos países em desenvolvimento. Wilmoth (2018) destaca que o crescimento populacional concentrado nos países mais pobres dificulta a aplicação da nova agenda de desenvolvimento sustentável, tendo como desafio a erradicação da pobreza, da desigualdade e do combate à fome.

Segundo Alva (1997), quanto maior a cidade, mais ela dependerá de recursos ambientais externos e gerará impacto no entorno. Tickell (2001) compara o funcionamento das cidades com o de organismos, pois elas dependem de recursos para sua sobrevivência, como água, alimentos, mercadorias, combustíveis, madeira, ao mesmo tempo que rejeitam no sistema resíduos gasosos, esgoto e lixo. Girardet (2001) defende que as cidades, assim como outras reuniões de organismos, têm metabolismo próprio e devem buscar um modelo de funcionamento cíclico, para garantir sua duração, tendo em vista a grande escala de urbanização atual. Para Farr (2008), ao levarmos em conta as múltiplas interações entre os organismos de diversas escalas, podemos considerar a cidade como um ecossistema. 
MODELO METABOLISMO LINEAR
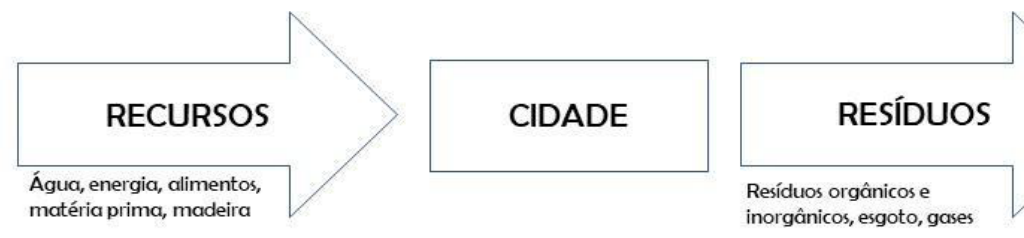

MODELO METABOLISMO CIRCULAR

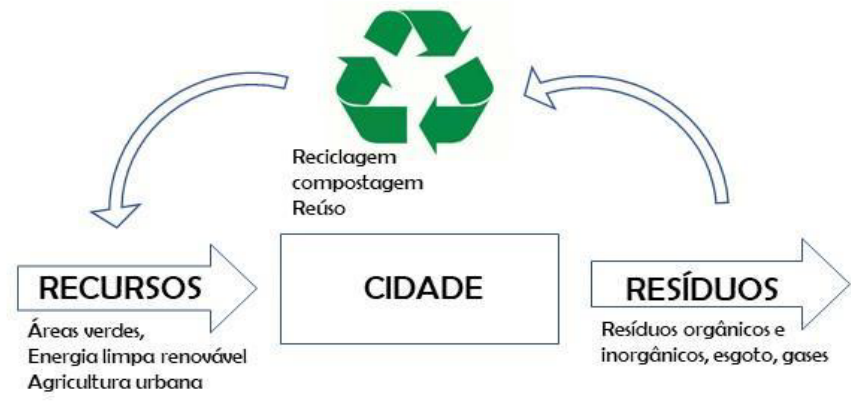

Figura 6 - Modelo de metabolismo urbano.

Fonte: Elaboração própria. Adaptada de Rogers (2001).

A geógrafa urbana Cyria Emelliannof (1995), a partir de um estudo realizado de 80 cidades europeias candidatas à sustentabilidade, identificou três discursos comuns entre elas, que podem ser divididos em: descentralização, restauração e interação. O primeiro discurso, da descentralização, tem como objetivo incorporar em suas políticas urbanas a integração tanto entre os centros e as periferias quanto entre a geração presente e as gerações futuras, bem como entre humanos e não humanos, considerando a diversidade biológica presente nas cidades. O segundo discurso, da restauração, visa a restaurar e reciclar itens materiais, elementos naturais e até mesmo ofícios, imagens e bairros. O terceiro visa à interação de diversos fatores e atores ligados à cidade (Acselrad, 2011).

Segundo Rattner (2011), a necessidade de atender a um consenso “integracional biosférico” (Acselrad, 2011, p. 26) a respeito da sustentabilidade frequentemente tem como objetivo a legitimação de uma política urbana que busca a promoção das cidades, dando-lhes maior valor competitivo. Acselrad (2009) identifica três representações distintas como matrizes discursivas da sustentabilidade e que se desdobram em modelos diversos, de acordo com o enfoque abordado pelas políticas urbanas. 
REPRESENTAÇÃO

TÉCNICO-MATERIAL

ESPAÇO DA

QUALIDADE DE VIDA

RECONSTITUIÇÃO E LEGITIMIDADE DE POLÍTICAS URBANAS
1.1 Modelo racionalidade ecoenergética

1.2 Modelo equilíbrio metabólico

\subsection{Modelo da pureza}

2.2 Modelo da cidadania

2.3 Modelo do patrimônio

3.1 Modelo da eficiência

$\Rightarrow 3.2$ Modelo da equidade

Figura 7 - Matrizes discursivas da sustentabilidade urbana.

Fonte: Adaptado de Ascelrad (2009, p. 65).

Segundo o autor, pela representação “técnico-material”, uma cidade sustentável é aquela que é capaz de otimizar o consumo de energia e outros recursos materiais, reduzindo o volume de rejeitos e mantendo o equilíbrio metabólico entre os fluxos e estoques de matéria e energia. Já a cidade como espaço de "qualidade de vida” diz respeito a espaços saudáveis, agradáveis, que valorizem a sensação de identidade e cultura e promovam a pureza das técnicas e da promoção da cidadania. A “legitimação das políticas urbanas” como um dos discursos que compõem a matriz de sustentabilidade representa a importância da eficiência de políticas para uma distribuição equitativa dos recursos e da infraestrutura urbana, respeitando as demandas geradas pelo crescimento das cidades, para que não ocorra o esvaziamento das áreas e garanta sua duração.

Como consequência da adoção de políticas que promovem um processo de gentrificação dos espaços e má distribuição dos recursos disponíveis na cidade, parte da população muitas vezes se vê obrigada a morar em áreas mais distantes dos centros urbanos. Essas áreas com frequência são espaços sem infraestrutura, com maior necessidade de deslocamento para o trabalho e próximas a encostas, com riscos de deslizamentos e outros eventos naturais. A redução das desigualdades e a distribuição justa dos equipamentos urbanos tornam-se, portanto, uma forma de promover um maior desenvolvimento com a melhoria das condições de bem-estar social, justiça ambiental, empoderamento e fortalecimento das cidades diante dos possíveis riscos ambientais e antrópicos. 
Um dos objetivos do desenvolvimento sustentável (ODS) definidos como meta para a Agenda 2030, o ODS 11 - Cidades e Comunidades Sustentáveis visa a "tornar as cidades e os assentamentos humanos inclusivos, seguros, resilientes e sustentáveis”. O Glossário do Objetivo do Desenvolvimento Sustentável 11, lançado no Brasil em junho de 2018, tem como objetivo servir como base de discussão para o debate de políticas públicas pela definição de referências e conceitos, deixando claras a relação e a importância da construção de cidades e comunidades mais sustentáveis para o desenvolvimento sustentável.

A Nova Agenda Urbana, proposta pela ONU, ${ }^{5}$ reafirma o compromisso com o desenvolvimento urbano sustentável de forma participativa e integrada, envolvendo as diversas escalas, sendo estas: locais, nacionais, subnacionais, regionais e globais. O documento ressalta ainda a importância de construir espaços que “adotem gestão do risco de catástrofes, reduzam a vulnerabilidade, construam resiliência e capacidade de resposta a perigos naturais e gerados pelo homem, e promovam a mitigação e a adaptação às alterações climáticas” (UN-HABITAT III, p. 4).

A construção de comunidades mais sustentáveis faz parte de um dos ODS publicados pela ONU e está presente nas agendas urbanas de diversas cidades pelo mundo. Tendo a sustentabilidade como um conceito fundamental para a sobrevivência das cidades e da vida no planeta, os novos projetos urbanos devem considerar as possíveis rupturas no espaço causadas pelas cidades, bem como as características essenciais para a promoção de um desenvolvimento sustentável e equitativo.

A concepção da sustentabilidade formada a partir do tripé econômico-socialambiental ainda é a ideia mais difundida entre os diversos campos de conhecimento a respeito do tema. Ignacy Sachs (2008) definiu, a princípio, cinco dimensões da sustentabilidade, as quais, recentemente, foram ampliadas para oito pelo próprio autor, que devem ser consideradas simultaneamente, sendo estas: social, cultural, ecológica, ambiental, territorial, econômica, política nacional e política internacional.

Segundo Uzzel (2002), a sustentabilidade não é um estado inalterado, mas um processo em construção contínua e criativa, que deve ter como objetivo o equilíbrio entre todas as áreas no processo de gestão das cidades. Cada cidade deve buscar sua própria sustentabilidade, visto que é única e tem sua particularidade. O autor destaca

\footnotetext{
${ }^{5}$ ONU. UN-Habitat for a better urban future. Implementing the new urban agenda. 2016.
} 
ainda a importante relação entre identidade e sustentabilidade. Por meio de um processo comparativo realizado entre duas cidades, o autor identificou que os usuários teriam mais cuidado com os espaços que têm maior identidade, que, no entanto, deve estar sempre relacionada, em sua complexidade, com outros fatores, como coesão social e “satisfação residencial” (Uzzel, 2002).

Os aspectos culturais são, normalmente, considerados uma importante ferramenta para o desenvolvimento de algum outro pilar da sustentabilidade, como o econômico (gerar renda e emprego) ou o social (empoderamento de minorias).

No entanto, se considerarmos como premissa inicial o conceito de desenvolvimento como ferramenta para melhorar as condições de bem-estar social, garantindo as liberdades, para que as pessoas possam ser aquilo que desejam, devemos ter em vista que as percepções do que é o desenvolvimento para cada indivíduo vão variar de acordo com suas referências de identidade e cultura, tempo e espaço. Portanto, mais do que como apenas uma ferramenta, os aspectos de identidade e cultura devem ser entendidos como pilares centrais para o desenvolvimento sustentável, pois são eles que vão indicar o caminho a ser percorrido.

Lemos (2010), à luz de autores como Thomas (2003), Jenks \& Dempsey (2005) e da Agenda 21, destaca alguns princípios fundamentais para a consolidação de uma cidade sustentável, entre os quais se incluem:

a) integração e justiça social e físico-territorial; b) adequação da relação com recursos naturais e o ambiente; c) aumento da durabilidade e redução da ociosidade; d) abordagem integrada; e) promoção da diversidade; f) reconhecimento de limites; g) qualificação dos aspectos setoriais. (Lemos, 2010, p. 168, Quadro 5).

Ao levarmos em conta os diversos princípios nos quais se consolidam as cidades sustentáveis, podemos verificar a forte relação e a importância de aspectos tanto ecológicos quanto sociais. Alguns princípios presentes para a elaboração de critérios de sustentabilidade destacados por Lemos (2010), como a distribuição justa dos recursos urbanos, o acesso à habitação, o processo participativo na tomada de decisões, o combate à pobreza e a promoção da diversidade econômica e social, podem ser facilmente considerados aspectos sociais. Ao mesmo tempo, outros aspectos, como a redução da poluição e de resíduos, a geração de energia limpa, a promoção da biodiversidade, entre outros, normalmente estão associados a características ecológicas. Entretanto, devemos ter um olhar integrado entre os 
diversos aspectos, suas origens e consequências. Ao se negligenciar um desses princípios, como a distribuição justa dos recursos urbanos - por exemplo, o saneamento básico — , pode-se piorar a situação de outros princípios de forma direta e indireta, como a diminuição da poluição — por meio de redes de esgoto sem tratamento — ou da promoção da diversidade, por exemplo.

A sustentabilidade tem dimensões diversas, que se relacionam de forma complexa. Para que seja possível promover um desenvolvimento de fato sustentável, é fundamental que todas as dimensões sejam devidamente consideradas na elaboração de projetos e planos urbanos, caso contrário é possível que determinada medida, ao desconsiderar uma das dimensões favorecendo outra, possa agravar ainda mais as desigualdades e a privação das liberdades, ou ainda impossibilitar a garantia de adaptação e sobrevivência do próprio sistema. 


\section{3 \\ Metodologia para análise dos aspectos socioambientais e as contribuições para a sustentabilidade de projetos urbanos}

\section{1. \\ Dimensões, categorias e critérios}

\subsection{1.}

\section{Dimensões}

A pesquisa baseia-se no tripé da sustentabilidade, que categoriza suas dimensões em social, ecológica e econômica. No entanto, pela grande dificuldade de obtenção de dados sobre a implantação do projeto analisado que fossem suficientes e confiáveis a respeito de seus custos de aplicação e, além disso, por se tratar de um trabalho de análise do projeto em si — e não da gestão da operação urbana (incluindo processos de governança e gestão de serviços) e das obras executadas para sua implantação —, alguns critérios relacionados com a dimensão econômica e a governança não foram explorados. O trabalho proposto, portanto, focará apenas as dimensões ecológica e social, a qual foi considerada sociocultural.

As dimensões propostas pelo trabalho dialogam também com as matrizes discursivas descritas por Henri Acselrad (2009). A dimensão ecológica tem diversas categorias similares às propostas pelo autor no modelo de racionalidade ecoenergética e equilíbrio metabólico da representação técnico-material da cidade, enquanto a dimensão cultural relaciona-se, em parte, com o modelo do patrimônio, e a dimensão social, com o modelo de eficiência e equidade.

\section{a. Dimensão ecológica}

a.1. Eficiência energética

a.2. Poluição do ar

a.3. Recursos hídricos

a.4. Resíduos sólidos

\section{b. Dimensão sociocultural}
b.1. Aprazibilidade
b.2. Identidade e cultura 


\section{b.3. Diversidade \\ b.4. Inclusão e equidade}

\subsubsection{1. \\ Dimensão ecológica}

A primeira dimensão proposta dialoga com a materialidade e o funcionamento metabólico das cidades proposto pela representação técnico-material delas, tendo como objetivo a redução do consumo de combustíveis fósseis e demais recursos naturais pela “representação técnico-material das cidades” (Acselrad, 1999, p. 82). Beaucire (apud Acselrad, 2009) afirma que a fragmentação e a desdensificação das cidades consomem mais energia e custos em instalação de rede dos serviços públicos. Segundo Acselrad (2009, p. 55), as áreas urbanas sustentáveis devem por objetivo reduzir o impacto entrópico, adotando tecnologias que usem matéria e energia de forma renovável, bem como tecnologias que poupem espaço.

Ainda de acordo com o autor, é possível identificar uma divergência entre sustentabilidade local e global. Ao mesmo tempo que as cidades concentradas são capazes de reduzir o consumo per capita de recursos materiais, bem como energia e redes técnicas, a elevação da densidade das cidades e da produção de rejeitos pode também comprometer a sustentabilidade em nível local (Acselrad, 2009). Rogers (2001) identifica que o crescimento das cidades transforma-as em estruturas complexas e de difícil administração, nas quais se tornam obsoletos os padrões tradicionais de acomodação urbana. Rattner (2011) destaca que o crescimento das cidades e o aumento da concentração populacional nas áreas urbanas vêm distanciando-as da percepção do que as cidades deveriam ser; segundo o autor, um lugar para viver bem.

A noção de eficiência ecoenergética de uma cidade, segundo Acselrad (2009), consiste em diminuir o consumo de recursos naturais e energia não renovável. Já o metabolismo urbano circular tem como objetivo a redução do consumo pelo aumento da eficiência e de processos de reciclagem, diminuindo, assim, os impactos naturais decorrentes do crescimento e do adensamento urbano (Girardet apud Rogers, 2001).

Os critérios de análise do campo proposto pela dimensão ambiental levam em conta a preservação dos recursos naturais, bem como a redução do consumo de 
recursos naturais necessários para o funcionamento dos centros urbanos, como água, matéria-prima, energia e até mesmo o próprio solo utilizado para a concentração das cidades, minimizando os impactos gerados por elas no meio ambiente, garantindo ainda o fornecimento da infraestrutura necessária para seus habitantes.

\subsubsection{2. \\ Dimensão sociocultural}

Tendo em vista que o conceito de sustentabilidade não tem consenso quanto à sua aplicação, bem como quanto à sua interdisciplinaridade, Leff (2000) considera que o saber ambiental deve ser construído pelo diálogo entre os diversos grupos de identidades culturais. Portanto, é fundamental analisar o contexto cultural e tecnológico da região e como ela compreende a sustentabilidade.

A ideia da sustentabilidade fundamenta-se em um plano para atender às necessidades da geração atual, de forma a garantir os recursos necessários para que as gerações futuras sejam capazes de satisfazer seus próprios anseios. Nesse ponto, o conceito de identidade cultural, bem como seu resgate, de acordo com Leme (2006), pode ser usado como ferramenta para atingir a sustentabilidade, visto que, ao verificar as características culturais de um grupo, é possível fazer emergir os anseios do grupo em questão, facilitando a tomada de decisão pelos planejadores com relação às propostas para a sustentabilidade.

A dimensão sociocultural proposta pela presente pesquisa consiste ainda em abordar os aspectos sociais relacionados com a sustentabilidade urbana. A distribuição desigual dos recursos na cidade provoca uma quebra na eficiência técnico-material, bem como pressões em suas relações físicas e sociais (Acselrad, 1999). Vale ainda destacar que os grupos menos beneficiados pelos investimentos em infraestrutura estão, normalmente, mais expostos aos riscos técnicos e naturais (Silva, 1991).

O desenvolvimento sustentável só é possível se for incluída uma política de redução das desigualdades sociais. A sustentabilidade como legitimação das políticas públicas (Acselrad, 2009) deve considerar o crescimento das cidades e o atendimento de suas demandas com eficiência e equidade.

Lemos (2010) destaca que os aspectos sociais do desenvolvimento devem fazer parte da agenda da sustentabilidade ambiental, sendo alguns de seus princípios incorporados à agenda UN-Habitat (2009, box 1.1, p. 4). Entre os mais relevantes, 
estão: equidade dos serviços urbanos; integração social; planejamento considerando pessoas com deficiência; diminuição e prevenção da violência.

É ainda importante considerar que as necessidades de cada grupo ou lugar vão variar de acordo com o contexto. Marques (apud Leme, 2006, p. 110) questiona como seria possível planejar ações futuras com uma realidade incerta e parâmetros inseguros do passado. Leme (2006) responde a esse questionamento afirmando que, ao observarmos a cultura, são também observadas as necessidades do ser humano, por meio de uma teia, que deve estar em constante construção.

Assim, essa dimensão da sustentabilidade proposta remete aos aspectos urbanos capazes de promover o sentimento de pertencimento, garantindo a duração simbólica dos espaços, evitando seu esvaziamento e fortalecendo a comunidade diante do processo homogeneizador decorrente das pressões do mercado e da globalização.

Cada critério analisado (Figura 8, coluna da direita) relaciona-se com um ou mais categorias (Figura 8, coluna da esquerda) e dimensões de forma complexa. A partir do diagrama (Figura 8), foram identificados quais critérios referem-se a cada categoria, à qual, posteriormente, foi dado um peso de acordo com o grau em que ela pode impactar a sustentabilidade, levando-se em conta os princípios preestabelecidos. Como o mapa geral de análise será realizado a partir do percentual obtido entre os resultados de cada categoria, os critérios que se relacionam com várias categorias diferentes acabam influenciando mais o resultado final. 


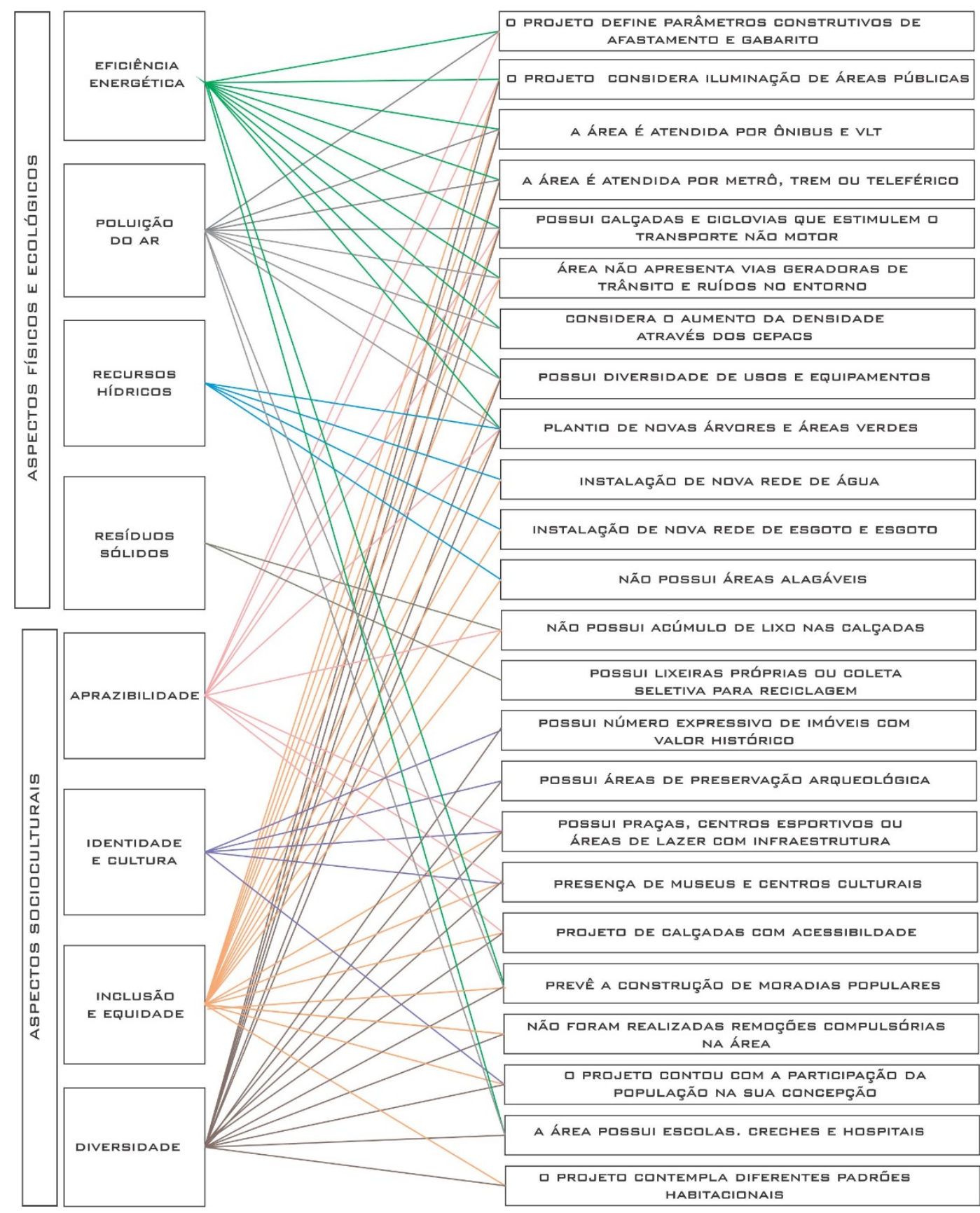

Figura 8 - Diagrama da relação entre princípios e critérios.

Fonte: Elaboração própria. 


\subsection{2.}

\section{Categorias e critérios}

\subsubsection{1.}

\section{Categorias de análise}

\subsubsection{1.}

\section{Eficiência energética}

A eficiência energética inclui a redução do consumo de energia e a adoção de políticas que promovam a redução das emissões de gases responsáveis pelo efeito estufa. Aproveitar o potencial local para gerar energia renovável ${ }^{6}$ também contribui para a redução do consumo de energia geral. Outros fatores, como arborização urbana e mobilidade, por exemplo, também contribuem para a melhoria da eficiência energética.

A categoria tem como objetivo atingir a eficiência energética, diminuindo o gasto de energia e o consumo de combustíveis fósseis para o funcionamento metabólico das cidades.

\subsubsection{2. \\ Poluição do ar}

A qualidade do ar é um princípio fundamental para a manutenção da biodiversidade, da saúde da população e da mitigação do efeito estufa. Muitos dos critérios relacionados com a qualidade do ar também estão relacionados com a eficiência energética; no entanto, ambos têm suas peculiaridades, como a redução do uso de combustíveis fósseis, a instalação de um sistema de transporte eficiente e que não gere vias de congestionamento, espaços com conforto bioclimático que evitem a necessidade de condicionamento do ambiente.

\subsubsection{3.}

\section{Recursos hídricos}

O plano estratégico desenvolvido para a cidade do Rio de Janeiro contempla, como algumas de suas metas, a expansão do saneamento, o cuidado com as águas

\footnotetext{
${ }^{6}$ A promoção da geração de energia a partir do tratamento de resíduos é ainda uma das diretrizes destacadas pelo programa "Rio verde, limpo e saudável".
} 
fluviais e o controle de enchentes dentro do campo urbano ambiental. "Rio verde, limpo e saudável” é, portanto, um princípio de fundamental importância na elaboração de projetos urbanos mais sustentáveis. O item “água potável e saneamento" faz ainda parte da ODS6, que, entre outras metas, tem como objetivo o acesso universal e equitativo à água potável, segura e acessível; o alcance de saneamento e higiene adequados e equitativos para todos; a melhoria da qualidade da água; a melhoria da eficiência do uso da água; a proteção e a restauração de ecossistemas relacionados com a água; e o fortalecimento da participação das comunidades para melhorar a gestão da água e do saneamento.

\subsubsection{4. \\ Resíduos sólidos}

O Plano Estratégico do Rio de Janeiro considera ainda como uma de suas diretrizes a promoção de geração de energia por meio de técnicas de tratamento de resíduos sólidos e a diminuição da quantidade de resíduos em aterros sanitários. O programa “Gestão Sustentável de Resíduos Sólidos”, desenvolvido pelo plano, pretende estimular a reciclagem e reduzir a disposição de matéria em aterros por meio de unidades de compostagem, biometanização no Caju, unidade de tratamento de resíduos da construção civil (RCC) no Caju; unidade de tratamento mecânico (UTM) no Caju, entre outros. Em dezembro de 2018, a Companhia Municipal de Limpeza Urbana (Comlurb) iniciou a primeira unidade de biometanização da América Latina, que visa a transformar os resíduos sólidos urbanos em biogás no Ecoparque do Caju. O espaço também realiza tratamentos de resíduos da construção civil, entre outros sistemas de tratamento. Apesar da proximidade, o Ecoparque do Caju não está localizado dentro da área contemplada pelo Porto Maravilha; no entanto, a relevância do princípio é notória para a criação de cidades mais sustentáveis.

O princípio analisado contempla a necessidade de destinar corretamente o lixo e incluir mobiliário que favoreça a reciclagem em todas as áreas do projeto.

\subsubsection{5.}

\section{Aprazibilidade}

A categoria da aprazibilidade ressalta a importância de criar espaços de convívio que favoreçam o bem-estar do usuário, permitindo maior sensação de 
pertencimento e favorecendo o uso dos espaços livres. O princípio proposto tem como base a diretriz criada pela Agenda Sociambiental da PUC-Rio, ${ }^{7}$ que descreve: “Os espaços devem ser cordiais, belos e que favoreçam o bem-estar dos usuários, a interação entre as pessoas com a natureza, permitindo a contemplação de paisagens, com conforto e segurança” (Agenda Socioambiental, PUC-Rio).

O princípio proposto tem como objetivo a diminuição dos espaços ociosos, aumentando o uso dos espaços públicos, a qualidade de vida, o bem-estar e a sensação de pertencimento de seus usuários.

\subsubsection{6. Identidade e cultura}

Por meio do resgate cultural e da perpetuação da identidade pelas gerações futuras, é também possível reforçar o sentimento de pertencimento de uma comunidade, garantindo sua diferença cultural em face do processo de homogeneização decorrente da globalização (Leme, 2006). A autora justifica ainda a importância do papel da identidade cultural para a sustentabilidade por meio de seis argumentos:

- Com o resgate da identidade e a análise da história, crenças e ideologias, é possível avaliar as mudanças ocorridas no tempo.

- O sentimento de pertencimento da comunidade gera mais união e possibilita a criação de bases políticas paralelas ao governo.

- Os tomadores de decisão podem ajustar os projetos de acordo com as necessidades e características do grupo.

- A identidade do grupo o fortalece, e ele passa a poder rejeitar pressões culturais externas que a descaracterizem.

- A comunidade mais fortalecida e consciente de suas necessidades passa a proteger seu espaço físico e a se defender de políticas que possam prejudicá-la.

- A garantia do espaço físico respeitado permite que o grupo possa difundir suas técnicas para outros grupos com soluções ambientais alternativas.

\footnotetext{
${ }^{7}$ A Agenda Socioambiental da PUC-Rio foi apresentada em junho de 2017 na XXIII Semana de
} Meio Ambiente. Universidade Sustentável. A Nova Agenda Socioambiental da PUC-Rio, ano II. 


\subsubsection{7.}

\section{Diversidade}

Para que um projeto seja considerado sustentável, ele deve considerar a importância da diversidade em seus diversos aspectos. A homogeneização dos espaços pode levar a um processo de gentrificação, de perda da identidade local e de esvaziamento dos espaços. O projeto urbano deve, portanto, promover a multiplicidade de usos, condições sociais e tipos de habitação.

\subsubsection{8.}

\section{Inclusão e equidade}

Lefebvre (2001) destaca o direito à cidade como o direito comum de toda a população a: mobilidade urbana, saúde, educação, participação política, fruição dos espaços públicos, entre outros anseios. O Estatuto da Cidade (2016) destaca também o direito a cidades sustentáveis para esta e para as futuras gerações, incluindo o acesso a: terra, moradia, saneamento, mobilidade urbana, infraestrutura, trabalho, lazer e serviços públicos.

O projeto urbano sustentável deve considerar a distribuição justa dos recursos, equipamentos e serviços urbanos, de forma inclusiva e integrada, a fim de diminuir as desigualdades e promover o desenvolvimento sustentável.

\subsubsection{9.}

\section{Critérios de análise}

Com o intuito de verificar como o projeto do Porto Maravilha interferiu na sustentabilidade urbana ao longo da região estudada, foram considerados 25 critérios de análise. Levando-se em consideração a multidisciplinaridade da sustentabilidade, o trabalho apresentado considera que cada critério pode também se relacionar com mais de uma dimensão da sustentabilidade, de forma complexa e interligada. 
3.1.2.1.9.1.

\section{Lista de critérios}

\section{Iluminação e energia}

1.1 Definição, no projeto, de parâmetros construtivos de afastamento e gabarito que permitam a entrada de luz natural em todas as unidades de residência e trabalho

1.2 Instalação de iluminação artificial das áreas públicas

\section{Mobilidade}

2.1 Atendimento da área por pontos de ônibus e veículo leve sobre trilhos (VLT)

2.2 Atendimento da área por sistemas de transporte de massa

2.3 Atendimento da área por ciclovias e calçadas que favoreçam o transporte não motor

2.4 Redução de vias geradoras de trânsito e ruídos no entorno

\section{Ocupação do solo}

3.1 Adequação do projeto urbano para atendimento do aumento da densidade prevista pela venda dos Cepacs

3.2 Atendimento da área por usos e equipamentos diversos

\section{Arborização urbana}

4.1 Plantio de novas árvores e áreas verdes

\section{Infraestrutura}

5.1 Instalação de rede de água

5.2 Instalação de rede de esgoto e drenagem

5.3 Aplicação de medidas para evitar alagamentos em regiões urbanizadas

\section{Gestão de resíduos sólidos}

6.1 Redução do acúmulo de lixo nas calçadas

6.2 Instalação de lixeiras no mobiliário e lixeiras para coleta seletiva

\section{Preservação e valorização do patrimônio}

7.1 Valorização do patrimônio arquitetônico com a presença significativa de imóveis tombados/preservados

7.2 Valorização e preservação de áreas arqueológicas

\section{8. Áreas de cultura e lazer}

8.1 Atendimento da área por praças, centros esportivos e áreas de lazer com infraestrutura 
8.2 Atendimento da área por museus e centros culturais

\section{Acessibilidade}

9.1 Atendimento por espaços públicos acessíveis

\section{Habitação}

10.1 Construção de novas moradias voltadas para a habitação popular

10.2 Manutenção da população local, não realizando remoções compulsórias

\section{Participação}

11.1 Participação da população envolvida em sua concepção

\section{Equipamentos urbanos}

12.1 Atendimento da área por escolas, creches e hospitais

\section{Diversidade}

13.1 Existência de diferentes padrões habitacionais, equipamentos e usos

\section{2. \\ Sistematização das informações}

\subsection{1. \\ Elaboração dos mapas das categorias individuais}

Foram elaborados mapas individuais para cada uma das oito categorias de análise elaborados pela pesquisa—eficiência energética, poluição do ar, recursos hídricos, resíduos sólidos, aprazibilidade, identidade e cultura, inclusão e equidade, e diversidade - classificando-se com cores distintas o grau de contribuição em cada área. Posteriormente, em uma etapa seguinte, as informações de cada categoria serão novamente unidas para a elaboração do mapa geral.

Com a elaboração dos mapas individuais de cada categoria, é possível identificar separadamente as contribuições em cada categoria analisada. Por exemplo, uma região pode ter uma contribuição significativa em eficiência energética, porém muito baixa em diversidade e equidade.

Para a elaboração de cada mapa das categorias, foi analisado individualmente se em cada região do projeto foram atendidos os critérios com os quais elas estão relacionadas, conforme identificado pelo diagrama de relação entre categorias e critérios (Figura 9). 


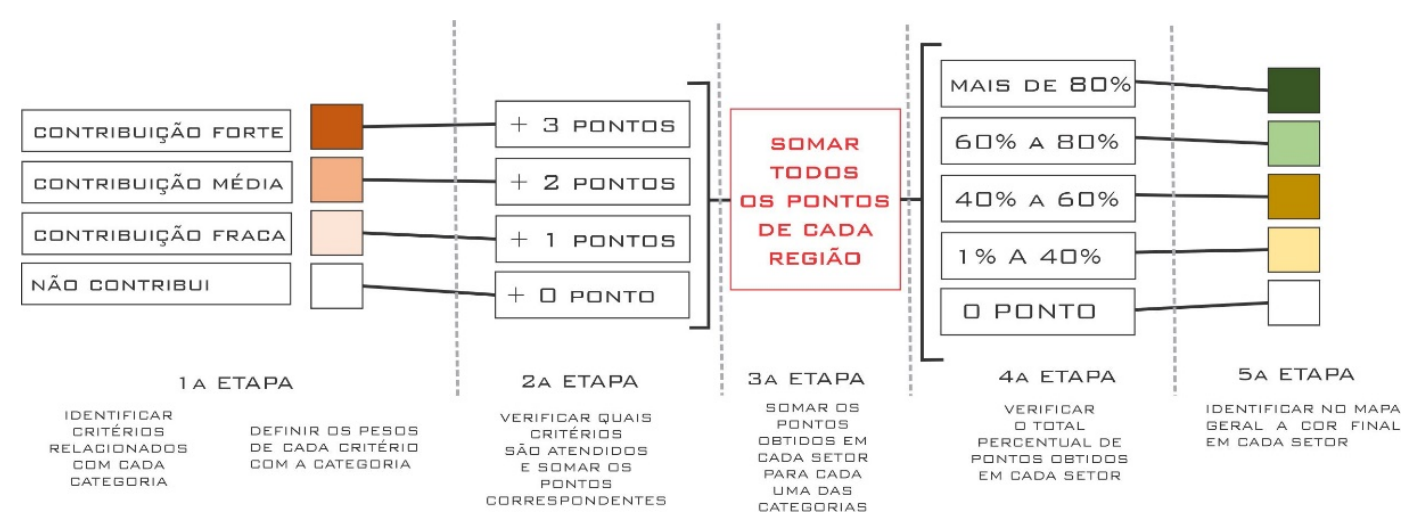

Figura 9 - Metodologia para elaborar os mapas de cada categoria.

Ao atender ao critério, o princípio recebeu uma pontuação, que variou de acordo com o grau de interferência desse princípio. Sempre que um critério era considerado fundamental e com contribuição para sustentabilidade forte, recebeu 3 pontos; importante e com contribuição para sustentabilidade média, 2 pontos; e com contribuição fraca ou impacto baixo, 1 ponto. O percentual do somatório obtido com relação ao total possível é mostrado com cor diferente no mapa. Uma área que teve $80 \%$ dos critérios atendidos, por exemplo, foi indicada no mapa com verdeescuro, enquanto as áreas que não tiveram nenhum critério atendido permaneceram com a cor branca. No final das oito categorias, ao juntar todas as informações obtidas, foi possível elaborar um mapa final, que sintetiza o resultado geral das oito categorias analisadas em apenas um mapa.

\subsection{2.}

\section{Elaboração do mapa geral}

O resultado final da pesquisa é representado cartograficamente. A partir da elaboração de um mapa geral, é identificada a contribuição para sustentabilidade distribuída em cada região do projeto analisado.

O mapa geral foi realizado a partir dos mapas de cada categoria. Sempre que uma categoria estiver verde-escuro, são somados 4 pontos; verde-claro, 3 pontos; marrom, 2 pontos; e amarelo-claro, 1 ponto. Se o setor tiver atingido pelo menos 80\% da pontuação total possível — calculada com relação à soma de cada categoria nos mapas anteriores - , recebe em seu setor correspondente a cor verde-escura; com $60 \%$ a $80 \%$, verde-clara; com $40 \%$ a $60 \%$, marrom; com $20 \%$ a $40 \%$, amarela; e com $0 \%$ a $20 \%$, branca (Figura 10). 


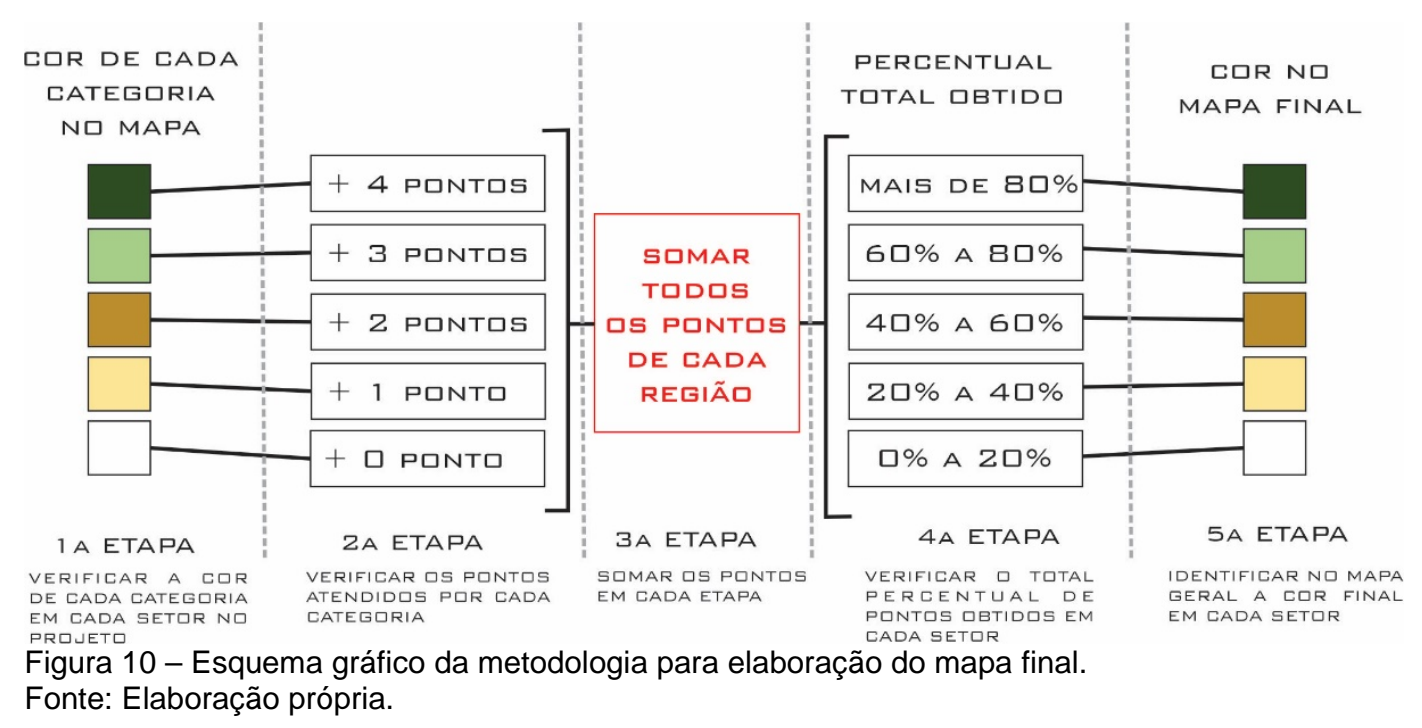

\section{3.}

Considerações metodológicas

\subsection{1.}

\section{Tipo de pesquisa}

A pesquisa apresentada foi desenvolvida com a análise dos documentos fornecidos pelas instituições competentes envolvidas no projeto, bem como com o resultado do trabalho de campo realizado em dias e locais distintos.

O trabalho de campo foi elaborado com entrevistas estruturadas (análise quantitativa) e semiestruturadas (análise qualitativa), realizadas tanto com os agentes envolvidos no desenvolvimento do projeto quanto com a população afetada por sua implantação.

\subsection{2.}

\section{Definição da amostragem}

\section{a) Quantitativa}

A pesquisa foi realizada a partir da elaboração de questionários realizados em uma amostragem estratificada por conglomerados, na qual a base foi determinada de acordo com o número de habitantes definido. A população ideal de cada amostra foi definida em 1\% (Richardson, 1999), de acordo com o diagnóstico elaborado em agosto de 2016. De acordo com o estudo de impacto de vizinhança (EIV) realizado, a população residente total da região é de 22.294 pessoas, sendo 10.490 na Gamboa, 9.618 no Santo Cristo e 2.186 na Saúde. No entanto, pela dificuldade de acessar 
algumas regiões, a amostra ficou um pouco abaixo desse percentual, embora ainda expressiva e tendo permitido bons resultados na combinação com outros métodos aplicados, como se verá a seguir.

Foram realizadas 125 entrevistas estruturadas, que foram aplicadas em dias, horários e locais distintos. Os locais foram escolhidos por terem características residenciais, com a presença forte de moradores, ou por agregarem o maior número e diversidade de pessoas utilizando os espaços, dando, assim, maior confiabilidade. São eles: Praça Mauá, Rua Acre, Rua Sacadura Cabral, Rua Camerino, Morro da Conceição (Bar do Sérgio), Pedra do Sal, Largo São Francisco da Prainha, Boulevard Olímpico, AquaRio, Ladeira do Livramento, Morro da Providência (Bar da Jura) e Morro do Pinto.

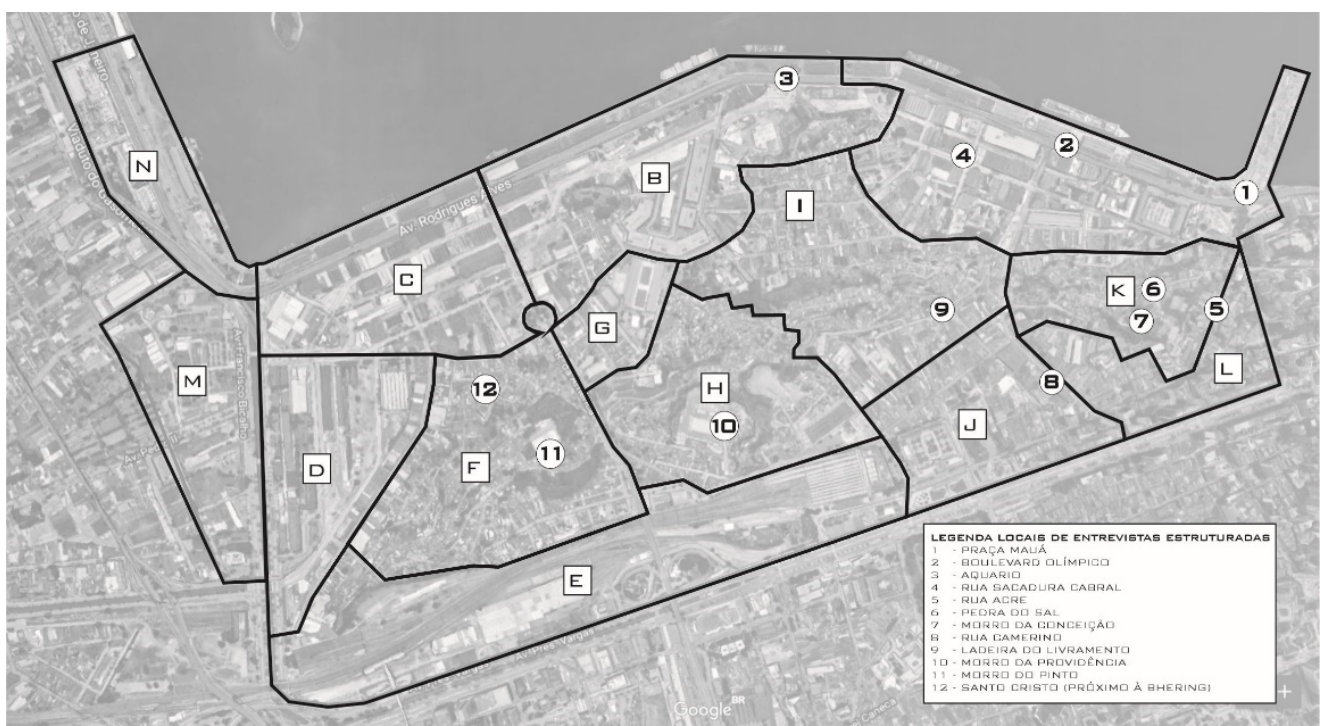

Figura 11 - Mapa com as regiões onde foram realizadas as entrevistas da pesquisa. Fonte: Elaboração própria.

A aplicação dos questionários foi realizada em um perfil diverso, que permitisse representar principalmente os grupos de pessoas recorrentes na área, os quais foram identificados por observação pessoal. A pesquisa incluiu diversos ambulantes, moradores, trabalhadores, turistas. As entrevistas realizadas no Morro do Pinto e no da Providência foram realizadas com o acompanhamento de um morador, por questões de segurança. Infelizmente, nos locais mencionados, a maioria das pessoas abordadas recusou-se a responder a qualquer pergunta, seja pela desconfiança, seja pela descrença que um trabalho acadêmico possa auxiliar sua vida de alguma forma. Muitos moradores respondiam que vários grupos de pesquisa vão ao local, no entanto nada é feito por eles. 
Por meio dos resultados das entrevistas, é possível ter uma noção geral das demandas e percepções dos interlocutores e usuários da área com relação a diversos aspectos, como sensação de pertencimento, iluminação pública, fornecimento de energia, abastecimento de água, sistema de esgoto, coleta de lixo, transporte público, segurança, acessibilidade, estado das calçadas, presença de árvores, ciclovia e áreas de lazer, conforme o Anexo 1. Dessa forma, este trabalho permitirá relacionar a abordagem do projeto sobre esses temas e seu impacto na ampliação da sustentabilidade na área.

\section{b) Qualitativa}

Também foram realizadas entrevistas semiestruturadas a partir de amostras intencionais, que foram definidas com grupos representativos da população e dos atores envolvidos.

\section{Identificação de interlocutores envolvidos e afetados:}

Para a elaboração da pesquisa, foram inicialmente identificados os interlocutores envolvidos e afetados pelo plano ou projeto. O Porto Maravilha afeta diretamente a vida de diversas pessoas que moram e transitam pelo espaço todos os dias e, para entender os maiores afetados, foram feitas visitas no local. Por meio de conversas com representantes locais e comerciantes foi possível identificar a população afetada.

A pesquisa contou com entrevistas realizadas tanto com representantes envolvidos na elaboração do projeto quanto com membros da população afetada por sua implantação.

Entre os representantes envolvidos na elaboração e na implantação do projeto, identificamos e realizamos entrevistas com o poder público, o presidente da CDURP e o representante do Patrimônio da Humanidade.

Com o intuito de identificar as demandas e percepções da população afetada, foram entrevistados diversos moradores (Morro da Providência, Morro da Conceição e Morro do Pinto); músicos da Pedra do Sal; comerciantes locais (Armazém 4, Bodega do Sal, Bar do Sérgio, Bar da Jura, Bar do Omar); e representantes de projetos culturais (Instituto Pretos Novos [IPN], Casa da Tia Ciata, Cia de Mystérios). 


\section{Roteiro de entrevistas:}

As entrevistas qualitativas foram realizadas seguindo modelo semiestruturado. Um pequeno roteiro de entrevistas foi elaborado para o grupo com o intuito de auxiliar que as entrevistas mantivessem o tema como foco de análise, que consistia principalmente em verificar quais eram as expectativas com relação ao projeto, se o Porto Maravilha impactou sua vida, de que forma e se houve participação na concepção do projeto.

Roteiro de entrevista semiestruturada com a população afetada pelo projeto:

1 - A implantação do projeto do Porto Maravilha mudou sua vida?

2 - Quais foram os maiores impactos do projeto em sua vida?

3 - Você conhecia o projeto antes de sua implantação?

4 - Quais eram suas expectativas?

5 - O que melhorou, em sua opinião?

6 - O que piorou, em sua opinião?

7 - O que poderia melhorar, em sua opinião? 
4

\section{Estudo de caso: aspectos de sustentabilidade do Porto Maravilha}

\section{1. \\ O Porto Maravilha}

O presente capítulo tem como objetivo introduzir o objeto de estudo, contextualizando a concepção do projeto do Porto Maravilha, para que então seja possível realizar a análise proposta ao longo da pesquisa.

A região estudada, que teve, ao longo dos anos, as necessidades de sua população negligenciadas, tornou-se foco de atenção de grandes projetos urbanos. A obsolescência da região do porto do Rio, bem como sua proximidade com a região central da cidade, fez com que ela se tornasse atrativa pela probabilidade de captar novos investimentos.

A área estudada compreende o perímetro compreendido pela Operação Urbana Consorciada da região do porto do Rio, cuja intervenção baseia-se na Área de Especial Interesse Urbanístico da Zona Portuária, definida pelo Decreto Municipal nº 20.652/2006, posteriormente revogado pelo Decreto nํㅜㄹ. 26.852/2006. A área abrangida inclui os bairros da Saúde, da Gamboa, do Santo Cristo e Centro.

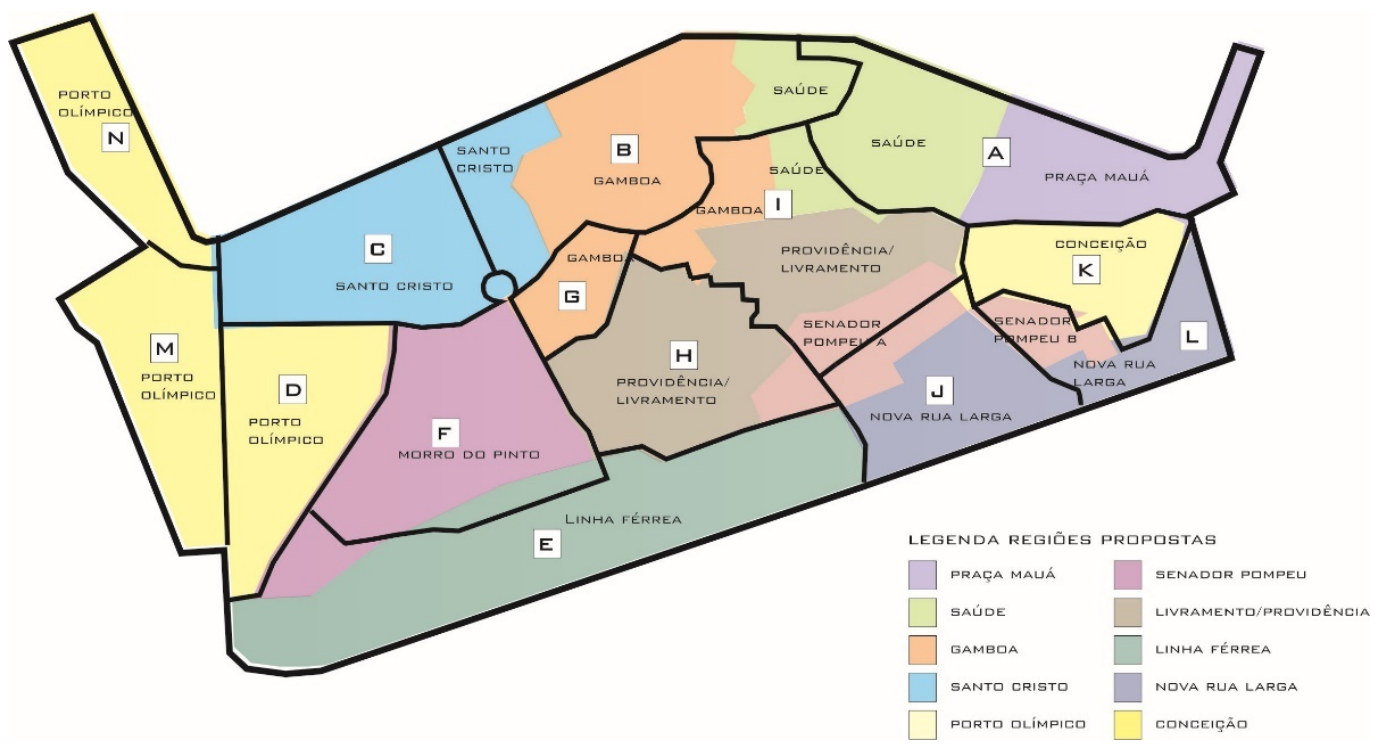

Figura 12 - Mapa da área do Porto Maravilha com setores propostos pelo plano. Fonte: Elaboração própria. 
A lei aprovada definiu os gabaritos e setores em que os Cepacs poderiam ser utilizados. O índice de aproveitamento dos terrenos na região foi definido com valor igual a 1, sendo possível acrescer a área construída pela aquisição dos certificados até o limite estabelecido pela lei. Os demais terrenos não contemplados pela delimitação deveriam pagar outorga, caso fosse acrescida área de construção interna.

No mesmo dia da aprovação da Lei n⿳00 101/2009, foi aprovada também a Lei nº 102/2009, que nomeia a Comissão de Desenvolvimento Urbano da Região do Porto como órgão gestor da área e transfere para ela a gestão dos serviços públicos por meio de decreto municipal. Dessa forma, foi viabilizada a PPP, em que a CDURP conferia à concessionária a prestação dos serviços que eram a ela designados. A partir dessas parcerias, foi viabilizada sua construção pela financeirização dos espaços pelos Cepacs, potenciais construtivos que poderiam ser comercializados na bolsa de valores para captação de recursos (Rolnik, 2015).

Durante o primeiro leilão oferecido pelo município, apenas um comprador arrematou o lote único dos certificados, a Caixa Econômica Federal (CEF). Por meio de recursos do FGTS, a CEF começou a participar da operação com a compra de todos os 6.436.722 títulos dos Cepacs pelo valor de 3,5 milhões de reais. ${ }^{8,9} \mathrm{Com}$ o intuito de assegurar a restituição do valor investido, bem como a liquidez de sua operação, o projeto passou a buscar, principalmente, novos investimentos que estimulassem a aquisição dos títulos disponibilizados. Nota-se, no caso do porto, uma situação peculiar em relação aos demais grandes projetos pelo mundo, que é seu financiamento por um fundo público (FGTS) e um forte protagonismo das empreiteiras como proponentes, formuladoras, planejadoras, implementadoras das obras, concessionárias dos serviços e sócias investidoras nas incorporações e nos empreendimentos (Rolnik, 2015).

O Porto Maravilha só se tornou possível porque havia uma parceria firmada entre as esferas municipal, estadual e federal que se justificou pela inclusão da área nos projetos voltados para os megaeventos. Como grande parte dos terrenos na

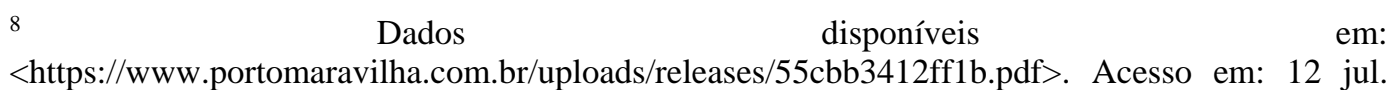
2018.

9 Segundo dados obtidos em: <https://www.portomaravilha.com.br/uploads/releases/55cbb3412ff1b.pdf>. Acesso em: 12 ago. 2018.
} 
região são públicos, era necessário que houvesse um acordo entre as três esferas que viabilizasse sua implantação.

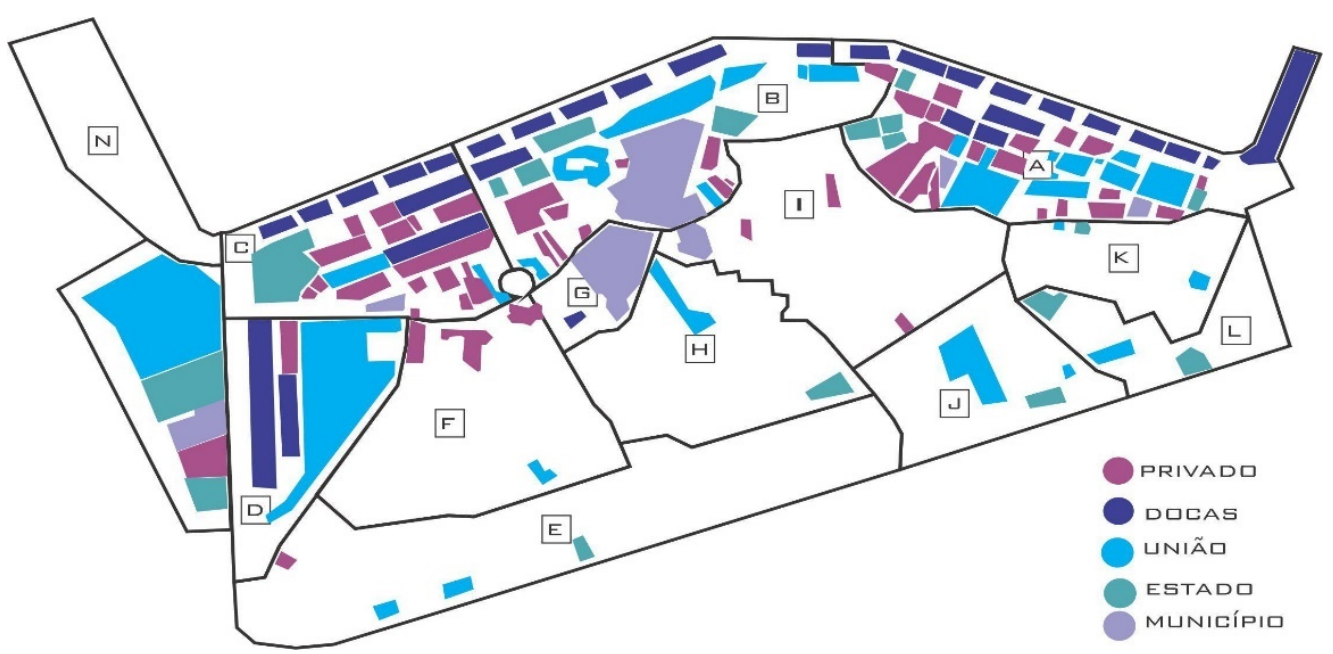

Figura 13 - Mapa da relação de propriedade dos terrenos do Porto Maravilha. Adaptado da planta CDURP.

A área do Porto Maravilha tem mais de 5 milhões de metros quadrados e inclui os bairros do Santo Cristo, da Gamboa, da Saúde e trechos do Centro, Caju, Cidade Nova e São Cristóvão (Figura 12). ${ }^{10}$

Seu desenvolvimento foi dividido em duas fases. Na primeira, foi desembolsado um valor de aproximadamente 139 milhões de reais pela Prefeitura, enquanto a segunda teria como estimativa um investimento de 6 bilhões de reais em 15 anos, viabilizados pelas PPPs, dos quais apenas uma parte foi realizada. Durante entrevista realizada com o atual presidente e diretor da CDURP, Antônio Carlos, até o momento já foram investidos em torno de 5 bilhões, havendo ainda uma previsão de mais 5 bilhões de reais em infraestrutura nos próximos sete anos.

A análise dos valores investidos nas obras do Porto Maraviha aponta para uma possível priorização na execução de grandes projetos monumentais — como o Museu do Amanhã, o Museu de Arte do Rio (MAR) e o AquaRio -, em detrimento de obras que têm como objetivo a melhoria da infraestrutura para atender às necessidades da comunidade local. Tal situação pode ser evidenciada pelo fato de que o Museu do Amanhã e o MAR, apesar de não terem sido inicialmente propostos, foram viabilizados pelos recursos que seriam destinados às comunidades

\footnotetext{
${ }^{10}$ Segundo dados obtidos em: <http://portomaravilha.com.br/portomaravilha>. Acesso em: 12 ago. 2018.
} 
envolvidas. Para que fosse possível a execução das obras dos museus, de acordo com a entrevista concedida pela CDURP, o então prefeito, Eduardo Paes, deslocou para esse fim uma verba de aproximadamente 380 milhões de reais, que estava destinada para obras de infraestrutura e reurbanização de áreas consolidadas pela população local e que necessitam de mais investimento em infraestrutura urbana, como o Morro do Pinto e o da Providência (Anexo 3).

É possível também identificar forte relação entre o projeto elaborado em Barcelona e o do porto do Rio (De la Garza, 2015), visto que foi criado inclusive um consórcio de operações urbanas entre empresas do Rio de Janeiro com parceria de empresas catalãs, a fim de "promover" a área do porto dentro de um destaque com respaldo internacional (De la Garza, 2015). Com o intuito de atrair novos investimentos para a área, passaram a ser executadas grandes obras simbólicas (Sánchez, 2015) e intervenções urbanas que pouco dialogam com as reais necessidades locais e não têm a participação efetiva da comunidade existente, que vivencia a "revitalização dos espaços” como forma de segregação social e geradora de expulsão (Smith, 1996). Isso muitas vezes acaba provocando um processo de gentrificação estratégica (Sánchez, 2015) e “autodestruição da diversidade”. ${ }^{11}$

\section{2. Processos de ruptura}

Segundo Vainer (2012), o Estado, no desenvolvimento de grandes projetos urbanos, pode agir mais como facilitador para a implementação desses projetos do que como agente regulador e representante dos interesses da sociedade (Vainer, 2012). Ainda de acordo com o autor (Vainer, 2012), grandes projetos urbanos são responsáveis por promover rupturas que podem ser intencionais ou não. As principais rupturas identificadas pelo autor são: institucionais, urbanísticas, legais, na dinâmica imobiliária e no gradiente de valores fundiários, simbólicas, políticas e escalares.

Para compreender as possíveis interferências do Porto Maravilha na área de estudo, são elencados a seguir, de forma geral, os processos de ruptura definidos por Vainer (2012) e como eles podem estar relacionados com o desenvolvimento e a implementação do projeto na região portuária.

\footnotetext{
${ }^{11}$ Em seu livro Morte e vida de grandes cidades, Jacobs (2011) destaca o processo de autodestruição da diversidade, no qual, quando uma área "dá certo", ela pode atrair investimentos e segregação social pela elitização dos espaços, afastando antigos usos e moradores que tornavam o lugar atrativo.
} 


\section{Rupturas institucionais:}

Segundo o autor, as rupturas institucionais ocorrem quando a implementação do projeto também possibilita a configuração de novos arranjos administrativos e institucionais para a gestão de seus espaços. Conforme mencionado, o projeto do Porto Maravilha viabilizou-se a partir da criação da PPP pela Lei Municipal $\mathrm{n}^{0}$ 101/2009 e pela Lei nº 102/2009, permitindo a criação da CDURP como órgão gestor do projeto e criando um novo tipo de administração e arranjo institucional para a gestão pública da região.

\section{Rupturas urbanísticas:}

Vainer (2012) define as rupturas urbanísticas como aquelas que geram descontinuidades na malha e na paisagem preexistente a partir de alguma atividade projetual.

A demolição da Perimetral foi uma das principais obras definidas pelo escopo do projeto do Porto Maravilha. Segundo o projeto apresentado, essa intervenção permitiria uma melhor integração dos espaços urbanos com a orla. No entanto, no lugar do antigo viaduto, foi concebido um projeto para a orla — das monumentais obras dos museus e das grandes torres espelhadas, dos armazéns, trapiches, imóveis antigos e residências com baixo gabarito. Outro ponto que merece destaque dentro do projeto é que o Boulevard Olímpico construído no lugar do antigo viaduto tem grandes trechos sem qualquer integração com as demais ruas da região portuária como entre a Praça XV e a Praça Mauá. Atualmente, um novo tipo de barreira pode estar se formando entre a população do local e a orla. A demolição da Perimetral e sua substituição pela construção do Boulevard Olímpico e pela Via Binário, portanto, possibilitam a criação de um novo tipo de ruptura urbanística, substituindo a barreira física da Perimetral pela simbólica dos grandes projetos. O projeto também determina trechos onde os lotes devem ter ao menos mil a 2 mil metros quadrados, não sendo permitido seu desmembramento. A definição de grandes lotes e gabaritos mais altos na estrutura urbana também pode representar uma descontinuidade na malha urbana existente, visto que a configuração atual é de uma tipologia com edificações baixas e em lotes pequenos e médios em grande parte da área projetada. 


\section{Rupturas legais:}

As rupturas legais podem ser identificadas pelo autor quando uma lei é criada para regulamentar uma situação específica, não condizendo com o restante da legislação da área. A publicação da Lei Municipal nº 101/2009 e da Lei nº 102/2009 viabilizou a implementação da PPP, a exploração dos Cepacs e a criação da CDURP como gestor. A nova legislação permite que seja possível construir acima do padrão estabelecido a partir da aquisição dos certificados negociados pela bolsa de valores em regiões predeterminadas, enquanto nas demais áreas a construção está limitada ao fator correspondente, sendo necessário o pagamento da taxa de outorga onerosa quando autorizado o acréscimo solicitado.

\section{Rupturas na dinâmica imobiliária e no gradiente dos valores fundiários:}

A ruptura na dinâmica imobiliária ocorre quando alguma ação promovida pelo projeto acaba intervindo diretamente no processo de valorização ou depreciação de determinado lugar (Vainer, 2012). O projeto do Porto Maravilha tem em sua concepção a clara intenção de promover a requalificação das áreas que se tornaram obsoletas a partir de uma nova configuração urbana e estrutura portuária. ${ }^{12}$ A construção de obras monumentais, como o Museu do Amanhã, o MAR ou o AquaRio, bem como o incentivo para a construção de novos empreendimentos, acaba possibilitando o processo de valorização imobiliária da região e a gentrificação dos espaços. Outra situação que pode ser observada é o crescimento do número de imóveis desocupados com o aumento dos valores dos aluguéis. Em razão do aumento dos custos dos imóveis e terrenos, antigos moradores, não tendo mais como arcar com o aumento das despesas, viram-se obrigados a mudar de lugar, deixando os imóveis vazios. Para evitar que os prédios fossem ocupados, também foi possível perceber a descaracterização de alguns imóveis, como a retirada de telhas, por exemplo, e até mesmo a contratação de seguranças particulares.

\footnotetext{
12 Conforme documento apresentado pela revista Grandes Construções. Disponível em: $<$ http://www.grandesconstrucoes.com.br/Materias/Exibir/porto-maravilha-engenharia-propoe-odialogo-entre-o-passado-e-futuro?Pagina=3>. Acesso em: 25 abr. 2019.
} 


\section{Rupturas simbólicas:}

Para Vainer (2012), ruptura simbólica ocorre quando novas representações ou imagens da cidade são produzidas a partir da implementação de determinado projeto urbano. Fernanda Sánchez (2009) aponta que o Porto Maravilha, assim como as demais obras que foram concebidas pelos megaeventos esportivos, apropria-se do discurso de “revitalização” dos espaços com o intuito de legitimar a viabilização de novas obras e colocar a cidade do Rio de Janeiro dentro de um destaque global. Ainda segundo a autora, o referido discurso da "revitalização" subentende a inexistência de vida anterior na área, negligenciando a presença e a importância da população já consolidada nos espaços existentes. Essa situação pode ser identificada quando, durante a entrevista realizada para a presente pesquisa, o diretor da CDURP afirma acreditar que não seria possível que houvesse uma gentrificação dos espaços, já que não haveria ninguém morando neles. Tal fato demonstra que parte da população, e até mesmo da gestão pública, passa a desconsiderar a presença e a importância da população existente no local.

A região portuária do Rio de Janeiro tem grande destaque histórico na cidade por sua importância para a cultura da sociedade, principalmente da população negra. A construção do Museu do Amanhã como uma de suas principais obras custou em torno de 215 milhões ao projeto e pode representar a substituição da tipologia simbólica do passado pela pretendida pelo futuro.

\section{Rupturas políticas:}

Para o autor, as rupturas políticas acontecem quando a implementação do projeto permite a viabilização de novas alianças, bem como o surgimento ou a intensificação de processos de disputa pela legitimidade dos espaços públicos (Vainer, 2012). O projeto implementado para o Porto Maravilha, entretanto, foi desenvolvido sem a devida participação popular e encontrou diversos grupos, que se formaram como forma de resistência à implementação de algumas obras, que iam de encontro às suas necessidades - como foi o caso, por exemplo, do Fórum Comunitário do Porto, que surgiu como resistência ao projeto e discutia os processos de remoção previstos pelo Morar Carioca no Morro da Providência e a instalação do teleférico no mesmo local. Foi também formulado um processo, ainda não aprovado, que tinha como objetivo a instalação de uma Comissão Parlamentar de Inquérito (CPI) que investigue a operação do Porto Maravilha. 


\section{Rupturas escalares:}

De acordo com o autor citado, o projeto do Porto Maravilha foi resultado de uma parceria entre as esferas federal, estadual e municipal, e tinha como discurso a proximidade dos megaeventos e a inclusão da área como um novo cluster olímpico (Rolnik, 2015). Antes de o projeto desenvolvido ser aprovado, outros também haviam sido concebidos pela gestão municipal. No entanto, os embates políticos sobre a gestão do território surgiram como principal entrave e inviabilizaram sua aplicação (Rolnik, 2015). Segundo Rolnik (2015), a inclusão do Porto Maravilha como um dos projetos desenvolvidos para os eventos olímpicos acabou possibilitando que o projeto fosse então implementado, visto que grande parte dos terrenos era do governo federal.

\section{3. Definição dos critérios de sustentabilidade urbana no projeto do Porto Maravilha}

Tendo como premissa inicial que a sustentabilidade urbana é um conceito multidisciplinar e que deve considerar as relações de forma complexa e mutável, a presente pesquisa pretende apontar as conexões entre as categorias analisadas com suas relações. A pesquisa considera que um critério analisado pode impactar aspectos distintos da sustentabilidade. A arborização urbana, por exemplo, é capaz de impactar tanto a eficiência energética e a poluição do ar — pois melhora o desempenho bioclimático e recupera parte das emissões de gases - quanto a aprazibilidade e a diversidade — visto que promove espaços mais agradáveis e com maior diversidade ecológica.

\subsection{1.}

\section{Iluminação e energia}

Fonte: Mapa da infraestrutura executada versus prevista (Figura 14).

O fornecimento de energia e de iluminação pública está entre os fatores que podem contribuir para a eficiência energética e o equilíbrio metabólico das cidades, bem como possibilitar espaços mais aprazíveis e com sensação de segurança. A redução no consumo e o investimento em fontes de energia renovável para abastecer 
os centros urbanos podem, portanto, impactar diretamente a sustentabilidade de grandes centros urbanos.

Segundo Lemos (2010), o planejamento urbano deve reduzir a demanda de energia por meio de estratégias que consigam aproveitar as condições existentes para melhorar o conforto térmico dos espaços, adotar sistemas de geração de energia renovável e diminuir o consumo de combustíveis fósseis para os deslocamentos.

A iluminação pública é uma das metas previstas no planejamento estratégico para a cidade do Rio de Janeiro, que tem como objetivo o desenvolvimento sustentável urbano. A meta M69, que faz parte do tema Território Descentralizado Inclusivo e Conectado do plano citado, prevê a redução de até $40 \%$ do consumo de energia elétrica em iluminação pública até 2020. Pelo programa “Ilumina Rio”,13 a Prefeitura pretende substituir e modernizar os pontos de luz existentes por outros com menor consumo e espera, com a melhoria, aumentar também a segurança dos espaços públicos.

A categoria iluminação e energia foi analisada por meio de dois critérios distintos e posteriormente relacionados com as dimensões eficiência energética, poluição do ar, aprazibilidade, inclusão e equidade e diversidade, conforme justificado na fundamentação teórica.

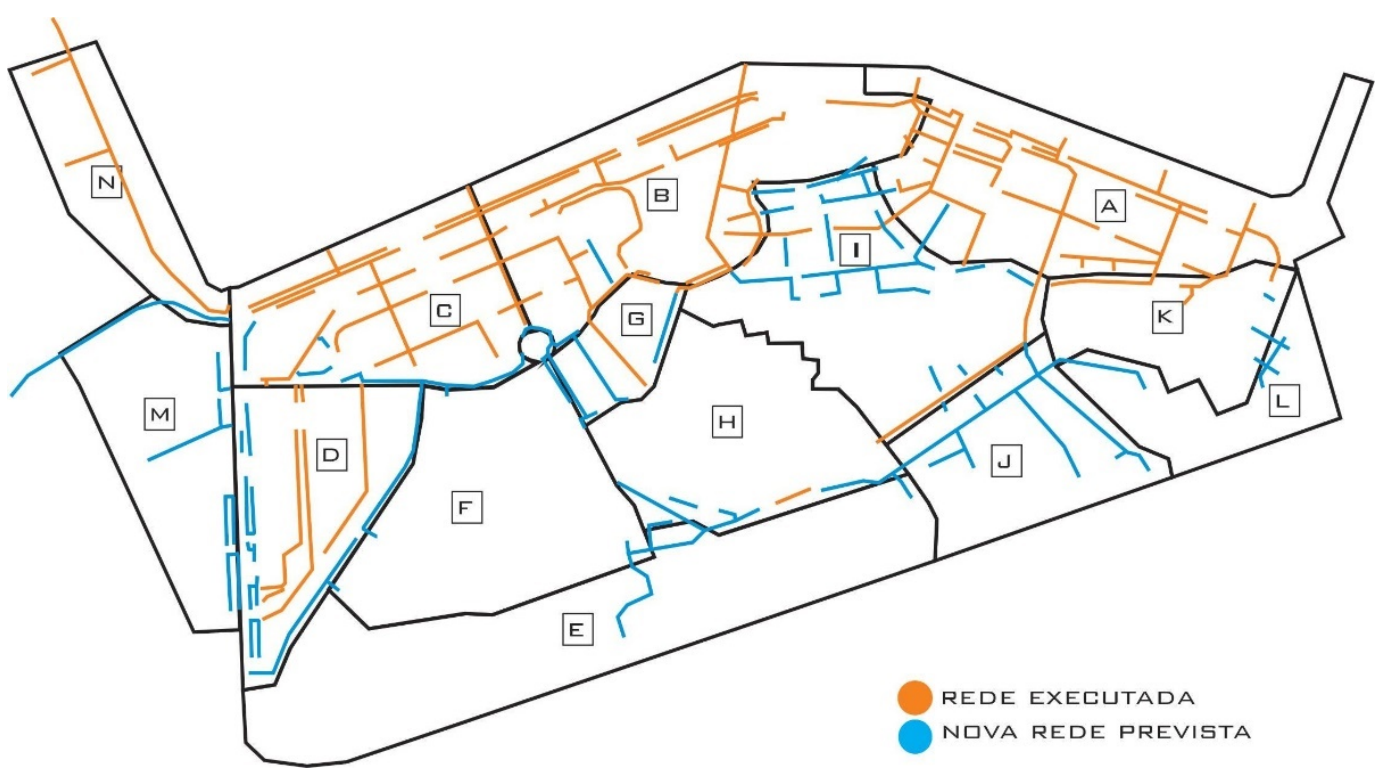

Figura 14 - Mapa da infraestrutura executada versus prevista do Porto Maravilha. Fonte: Elaboração própria, adaptado de planta CDURP.

\footnotetext{
${ }^{13}$ De acordo com o Plano Estratégico do Rio de Janeiro, o custo com os pontos representam mais de $60 \%$ do valor arrecadado para iluminação pública (Cosip). O programa "Ilumina Rio" indica a substituição das lâmpadas por LED ou por outro modelo mais moderno em $100 \%$ dos pontos da cidade até 2020 e prevê uma redução da emissão dos gases de efeito estufa e manutenção do índice de apagamento em $2 \%$.
} 


\subsubsection{1.}

Definição, no projeto, de parâmetros construtivos de afastamento e gabarito que permitam a entrada de luz natural em todas as unidades de residência e trabalho

Fonte: Mapa dos gabaritos (Figura 15).

Ao definir parâmetros construtivos que considerem o afastamento e o gabarito, o projeto urbano pode influenciar diretamente a eficiência energética e a poluição do ar — redução da necessidade de uso de condicionador de ar, por exemplo — e a aprazibilidade — pois permite áreas públicas com melhor desempenho bioclimático.

A partir da análise dos parâmetros construtivos fornecidos pelo mapa fornecido pela CDURP (Anexo 1), foi possível verificar que apenas as áreas A, B, C, D, E, F, I e M têm definição quanto ao afastamento e ao gabarito. No entanto, a legislação anterior definia nessas áreas um afastamento proporcional ao gabarito com o intuito de garantir sombreamento e ventilação adequados. Atualmente, a fim de possibilitar maiores gabaritos e viabilizar a venda dos Cepacs, essa restrição foi retirada da Lei n⿳ํㅗ 101/2009, o que pode representar uma perda da legislação para o conforto bioclimático urbano.

O EIV indicou a necessidade de plantio de novas árvores e monitoramento do desempenho, visto que a possibilidade de aumento de gabarito sem o afastamento proporcional, bem como a construção de grandes empenas que podem acumular calor, pode proporcionar a formação de ilhas de calor que antes não estavam contempladas.

O critério está relacionado com a eficiência energética - pois com parâmetros de ventilação é possível ter melhor desempenho bioclimático da edificação — , com a poluição do ar — visto que o melhor desempenho climático das edificações permite uma diminuição de uso de aparelhos de ar condicionado e com a aprazibilidade — a definição de afastamento e gabaritos pode permitir melhor sombreamento e ventilação dos espaços públicos. 


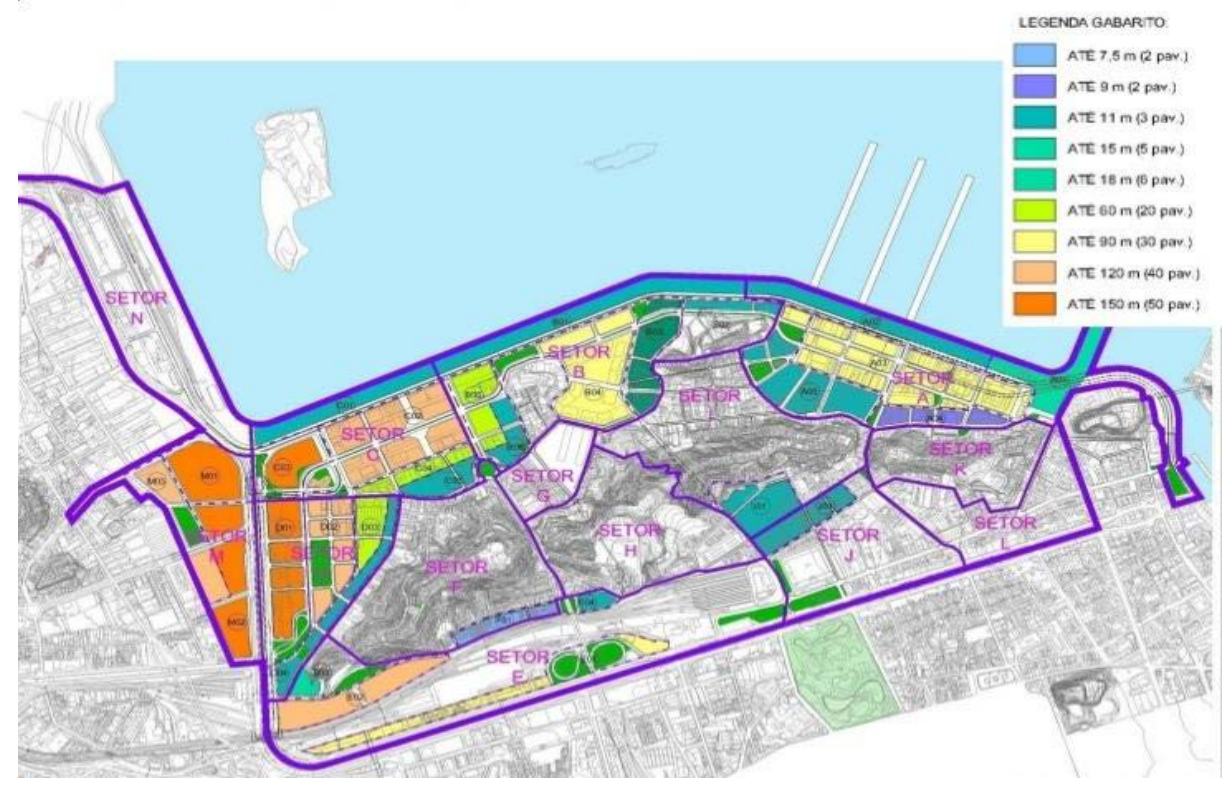

Figura 15 - Mapa dos gabaritos propostos para o Porto Maravilha. Fonte: CDURP.

\subsubsection{2.}

\section{Instalação de iluminação artificial nas áreas públicas}

Fonte: Mapa da infraestrutura executada versus prevista (Figura 14).

O critério considerou as informações fornecidas pela CDURP das vias urbanizadas e a urbanizar. A partir do projeto fornecido (Anexo 1), foi elaborado o mapa da infraestrutura urbana, que também serve de base para a análise de outros critérios, como abastecimento de água, esgoto e drenagem.

Pode-se perceber, a partir da análise do mapa elaborado, que os recursos investidos na infraestrutura urbana consideraram principalmente as áreas que receberiam maior investimento dos Cepacs, exceto pela região Portinho, onde está localizado o Morro da Conceição.

Algumas regiões, como a do Portinho, tiveram sua rede aérea substituída por fibra óptica. No entanto, os postes antigos não foram retirados e acabam gerando transtorno para a população. Parte dos entrevistados também reclamou que o poste instalado é sobreposto à calçada, causando pequenos acidentes nos moradores. 


\subsection{2.}

\section{Mobilidade}

A mobilidade foi uma das áreas mais impactadas pelo Porto Maravilha. Para sua construção, além da demolição da Perimetral, foram executadas obras em diversas ruas, incluindo a construção de vias novas, túneis, uma rede de VLT e um passeio de pedestres pela orla.

A promoção de um sistema eficiente e sustentável pode contribuir para a redução de gases que agravam o efeito estufa, além de possibilitar um aumento na diversidade de usos e integração com outros bairros. O programa de mobilidade sustentável deve prever estudos que reduzam o uso de automóveis, favorecendo o trânsito de pedestres e veículos não motores, com baixa emissão de gases e transporte de massa. Segundo Moller (2006), a cidade deve ainda incentivar a micromobilidade (circuitos a pé ou de bicicleta), em detrimento da macromobilidade (grandes distâncias).

Ewing (apud Barczak, 2012) define como estratégias para mobilidade: densidade, diversidade, design (característica da rede), acessibilidade e distância. O autor contrapõe ainda a ideia de que as cidades mais adensadas por si só reduzem o consumo de energia e emissões de $\mathrm{CO}_{2}$, visto que a concentração de um único tipo de viagem - como da área residencial para a área comercial — pode aumentar significativamente o congestionamento, o que gera maior consumo de energia, mesmo que haja redução das distâncias.

Reduzir os espaços destinados aos automóveis, segundo Mascaró (2005), é a única alternativa para criar espaços com diversidade que priorizem os pedestres e o convívio entre os habitantes. Deve-se restringir a circulação de veículos motorizados a partir do desenvolvimento orientado ao transporte público (transitoriented development [TOD]), considerando-se a concentração da população próxima ao serviço de transporte público integrado com múltiplas opções como condição para maximizar sua eficiência.

A demolição da Perimetral foi uma das principais obras da primeira fase de obras do Porto Maravilha, a qual estava orçada em 200 milhões. No entanto, não foi possível conseguir uma informação concreta a respeito de seu custo final, considerando-se ainda todas as obras de apoio para viabilizar a intervenção. 
Izaga (2017) dividiu a demolição da perimetral em três etapas, fazendo uma análise dos impactos na mobilidade urbana de cada uma delas.

A primeira etapa da obra refere-se ao trecho compreendido entre a Praça XV e a Candelária. De acordo com a autora, esse processo remonta ao ano 1997, quando o então prefeito Conde já questionava a demolição do viaduto para a pedestrificação, deixando o fluxo de veículos para o Mergulhão e mantendo livres as áreas terrenas. O estudo identifica que essa etapa seria a que mais valorizaria a cidade, pois se trata de um trecho consolidado do antigo frontispício da cidade, com importantes espaços públicos e edifícios históricos que antes eram fracionados pelo viaduto.

A segunda etapa da demolição do viaduto compreende o trecho entre a Candelária e a Praça Mauá, onde atualmente existe o Túnel Rio 450 Anos. Por sua proximidade com o Mosteiro de São Bento, a construção do túnel havia encontrado obstáculos na década de 1960 e só pôde ser implementada com o desenvolvimento tecnológico atual. De acordo com a autora, nesse trecho é que houve de fato uma devolução de uso ao pedestre, visto que a proximidade da Ilha das Cobras e do Arsenal da Marinha impõe normas de segurança que restringem o acesso e construções próximas. Nessa área, também foram construídos o Museu do Amanhã e o MAR, reintegrando a Praça Mauá ao uso público.

O terceiro trecho da demolição é o mais extenso e pode ser subdivido em outros dois segmentos. O primeiro foi definido como a área que vai da Praça Mauá ao AquaRio, e o segundo, entre o AquaRio e a Rodoviária. Para atender aos veículos que antes transitavam pela Perimetral, foi construída uma via expressa, que compreende a Via Binário, entre a segunda fileira de armazéns, e o Túnel Marcello Alencar. Entre a Praça Mauá e o Armazém 8, em paralelo à linha 1 do VLT, o trecho é prioritariamente de pedestres. No entanto, de um lado encontram-se os armazéns de uso privado, que impedem a comunicação com o mar, e, do outro, seguem grandes empenas de edifícios, que recebem painéis que visam a "remediar a ausência de uma frente urbana ativa” (Figura 19). Foi também construída uma via expressa em nível entre os Armazéns 8 e 18 - Avenida Rodrigues Alves —, a qual se desenvolve sem semáforos e impede seu atravessamento, o que acaba seccionando o espaço (Figura 16). 


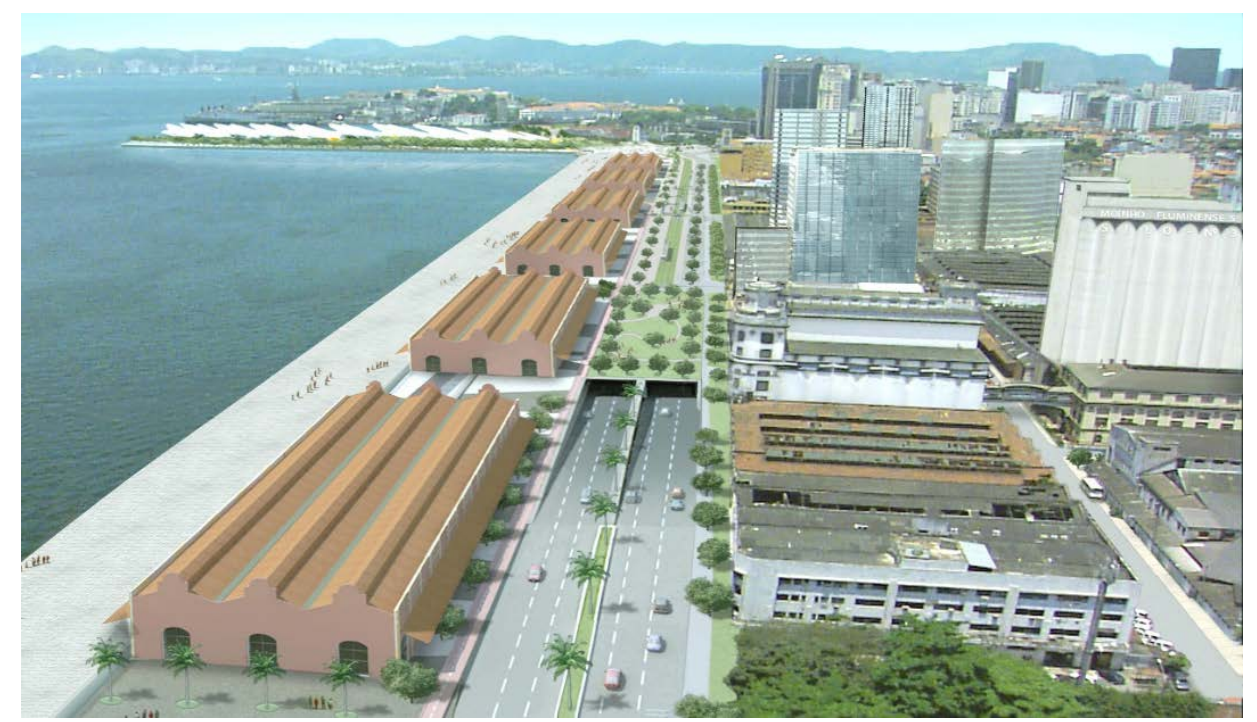

Figura 16 - Situação proposta para o Boulevard e a Via Binário.

Fonte: <http://ligadonorio.blogspot.com/2013/07/porto-maravilha-cidadao-promove-2.html>. Acesso em: 25 abr. 2019.

Izaga (2017) também destaca que, apesar de a linha 1 do VLT percorrer todo o trecho do Boulevard, interligando a Praça XV ao aeroporto, atende apenas à população que já se encontra no Centro e trabalha nos escritórios ou ao fluxo de turistas, não sendo utilizada pelos moradores da região. A obra do sistema modal, estimada em 1,2 bilhão, não tem atingido a rentabilidade prevista, um dos motivos pelos quais alguns entrevistados justificam o possível interesse em diminuir o trânsito de ônibus pela região.

Pela leitura da análise apresentada pelo Enanpur 2017 (Izaga, 2017), é possível verificar que a demolição da Perimetral não atingiu o principal objetivo de reintegração da cidade com o mar na maior parte de sua extensão. Seja por conta das vias expressas, da presença de imóveis privados ou pelo controle de acesso do Boulevard, a maior parte do trecho da orla não tem comunicação efetiva que integre a orla com a cidade, garantindo sua permeabilidade.

O EIV elaborado para a região também indica o aumento de emissão de gases após a realização do projeto. Segundo o documento, antes do Porto Maravilha circulavam, em média, 131.268.810 veículos por ano pela região, que geram 69.713.123 toneladas de $\mathrm{CO}_{2}$, e o número após a implantação do projeto passaria para 193.903.215 veículos por ano e com estimativa de 107.569.694 toneladas de $\mathrm{CO}_{2}$ por ano. A emissão de gases, portanto, poderá aumentar em aproximadamente 50\%, o que indica grande impacto na sustentabilidade urbana. 


\begin{tabular}{|c|c|c|c|c|}
\hline Cálculo & \multicolumn{2}{|c|}{$\begin{array}{c}\text { Veículos movidos a } \\
\text { gasolinalálcool }\end{array}$} & \multicolumn{2}{c|}{$\begin{array}{c}\text { Veículos movidos a } \\
\text { diesel }\end{array}$} \\
\hline & 2009 & prevista & 2009 & prevista \\
\hline $\mathrm{CC} \mathrm{em} \mathrm{TJ}$ & 73667 & 110500 & 25196 & 37795 \\
\hline $\mathrm{QC} \mathrm{em} \mathrm{GgC}^{\mathrm{ECO}}$ em GgCO & 13923 & 20884 & 5090 & 7635 \\
\hline $\begin{array}{c}\text { Total de emissão em } \\
\text { toneladas }\end{array}$ & 51051 & 76576 & 18662 & 27993 \\
\hline
\end{tabular}

Tabela 1 - Cálculo da emissão de gases - situação anterior e futura. Fonte: EIV Porto Maravilha.

O projeto Morar Carioca incluiu a construção do teleférico que liga a Central do Brasil ao Morro da Providência, em um custo de 75 milhões, segundo matéria divulgada pela revista $P i n i,{ }^{14}$ sendo necessárias a realização de diversos despejos e a desocupação da quadra utilizada pelos moradores como área de lazer. O equipamento importado tem custo de manutenção em torno de 1 milhão por mês e parou de funcionar em 2016, quando o contrato foi encerrado.

O projeto urbano deve, portanto, prever um sistema de mobilidade sustentável, eficiente e integrado, capaz de conectar múltiplos destinos e que priorize a circulação de veículos não motores e de alta densidade, em detrimento do automóvel. Pela adoção de um planejamento voltado para a mobilidade sustentável, é possível promover a redução dos impactos ambientais gerados pela emissão de gases e o desenvolvimento da diversidade, tornando-a mais atrativa e inclusiva.

Conforme destacado durante entrevista com o presidente da CDURP, o engenheiro Antônio Carlos, o projeto do Porto Maravilha pretende acabar com a circulação dos ônibus dentro do perímetro do projeto. Dessa forma, seria possível aumentar o fluxo do VLT e sua rentabilidade. A implementação do VLT custou cerca de 1,2 bilhão de reais, sendo $46 \%$ desse recurso de fundo público, que seriam pagos em 270 parcelas pelo município para o setor privado (revista Pini). Pelo alto custo unitário e por não estar integrado aos demais transportes, a maioria dos moradores entrevistados não utiliza esse tipo de transporte.

A região do porto abriga grande parte dos empregos da cidade. No entanto, a presença de moradia ainda é pequena proporcionalmente, gerando, portanto, um grande número de viagens para o local diariamente. A demolição da Perimetral e a construção da Via Binário priorizam o uso do automóvel, ampliando o número de

\footnotetext{
${ }^{14}$ Disponível em: <http://piniweb17.pini.com.br/construcao/infra-estrutura/obra-do-teleferico-domorro-da-providencia-no-rio-de-288488-1.aspxe>. Acesso em: 25 abr. 2019.
} 
pistas voltadas para este, o que pode vir a estimular mais o transporte motor, em detrimento do transporte público.

As obras de construção de novas ciclovias e calçadas que estimulem o trânsito de pedestres foram realizadas ao longo do Boulevard Olímpico e não têm integração com as áreas residenciais já consolidadas.

Durante as entrevistas realizadas em campo, 57\% dos entrevistados que responderam se o projeto apresentou melhorias nesse setor consideram que o transporte público não melhorou com as obras realizadas, e 51\% acham que atualmente está fraco ou ruim. Metade dos entrevistados que consideraram que atualmente o serviço era ruim e que não apresentou melhoria respondeu que anteriormente o serviço era bom.

\begin{tabular}{|c|c|c|c|}
\hline \multirow{4}{*}{$\begin{array}{c}\text { Meio de transporte para o } \\
\text { trabalho (moradores que } \\
\text { trabalham dentro E fora do } \\
\text { bairro) }\end{array}$} & $\begin{array}{c}\text { A pé ou de } \\
\text { bicicleta }\end{array}$ & 32 & $59 \%$ \\
\cline { 2 - 4 } & VLT & 4 & $7 \%$ \\
\cline { 2 - 4 } & Ônibus & 8 & $15 \%$ \\
\cline { 2 - 4 } & Metrô e trem & 4 & $7 \%$ \\
\cline { 2 - 4 } & Carro ou moto & 5 & $9 \%$ \\
\hline
\end{tabular}

Tabela 2 - Meio de transporte dos moradores.

Fonte: Entrevistas no local.

Com o intuito de analisar o aspecto proposto, a pesquisa considera os seguintes itens: presença de pontos de ônibus e VLT; presença de transporte de massa, como trem e metrô; e construção de ciclovias e calçadas que favoreçam o trânsito de pedestres. A análise dessa área, considerada para as dimensões eficiência energética e poluição do ar, teve como critério de classificação a emissão de gases, sendo, portanto, mais sustentáveis — e com peso 3 na análise — as áreas que contemplam ciclovias e calçamento que favoreçam o trânsito de veículos não motores, transporte de massa, com peso 2, e presença de ônibus e VLT, com peso 1. A construção de novas vias de automóveis não foi considerada como um aspecto de sustentabilidade em mobilidade, visto que o estímulo e o aumento do fluxo de veículos motorizados, em detrimento do transporte público, podem ser fatores agravantes da mobilidade urbana, conforme mencionado ao longo da pesquisa. O aspecto mobilidade também tem relação com as dimensões inclusão e equidade e diversidade social, pois se entende que um sistema de transportes eficiente pode promover a diversidade social no local, atraindo pessoas para diferentes atividades, bem como aumentar a inclusão do bairro com outros lugares da cidade. Nesse 
aspecto, todos os sistemas receberam o mesmo peso, visto que a emissão de gases não influencia diretamente o desempenho das duas dimensões abordadas.

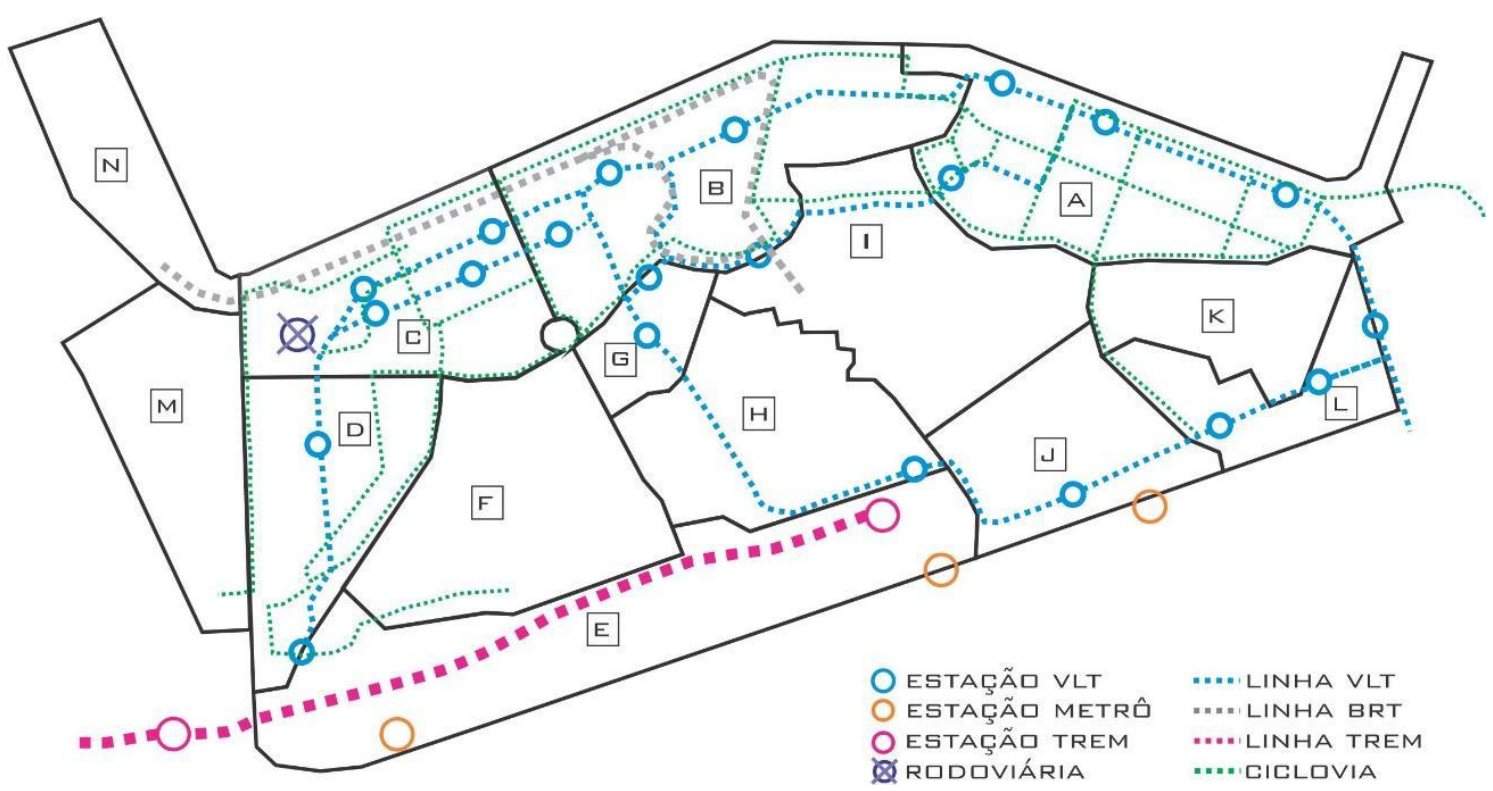

Figura 17 - Mapa de mobilidade do Porto Maravilha.

Fonte: Elaboração própria, com base na planta fornecida pela CDURP (Anexo 1).

\subsubsection{1.}

Atendimento da área por pontos de ônibus e veículo leve sobre trilhos (VLT)

Fonte: Mapa de mobilidade (Figura 17).

A presença de ônibus e de VLT favorece o transporte público e a eficiência energética, além de diminuir a poluição do ar, reduzindo a emissão de gases responsáveis pelo efeito estufa, e de melhorar os processos de inclusão e diversidade, pois promove a possibilidade de o espaço ser utilizado por classes sociais distintas, bem como possibilita sua integração com outras regiões da cidade.

O projeto apresentado propõe o fim da circulação de ônibus pelo Centro da cidade, conforme relatado pela entrevista realizada com o presidente da CDURP, substituindo-os pelo VLT, que seria uma opção mais sustentável. No entanto, entre o total de entrevistados que responderam utilizar o transporte público, apenas $8 \%$ costumam usar o VLT, e 23\%, o ônibus. Entre os moradores da região que participaram da pesquisa, apenas 7\% do total afirmaram utilizar o VLT como meio de transporte, e 15\%, o ônibus (Tabela 2). 
Pode-se perceber, a partir da análise do mapa elaborado, que os recursos investidos na infraestrutura urbana consideraram principalmente as áreas que receberiam maior investimento dos Cepacs - A, B, C, D, E, G, J e L.

O critério influencia diretamente a eficiência energética — custo energético com locomoção; a poluição do ar — pois diminui a emissão de gases; e a inclusão e equidade e diversidade - pois áreas em que se pode caminhar têm o potencial de promover a interação e a diversidade de usos nos espaços. No que tange à sustentabilidade, a pesquisa considerou que a presença de ônibus e de VLT tem impacto menor do que o percurso de transporte de massa como trem e metrô e do que o percurso de transporte não motor.

\subsubsection{2.}

\section{Atendimento da área por sistemas de transporte de massa} Fonte: Mapa de mobilidade (Figura 17).

A estação Central do Brasil é um importante ponto de conexão intermodal da cidade do Rio de Janeiro. Diariamente, ela recebe pessoas de diversos bairros, que fazem a transferência entre ônibus, trem e metrô. A maior parte da população que chega à região de bairros mais distantes o faz por metrô ou trem, passando pela estação.

O projeto do Porto Maravilha não propôs a ampliação e o fortalecimento do sistema de transporte de massa de forma geral, fundamental para integrar a região com o restante da cidade e melhorar a sustentabilidade urbana. Segundo Cosme, morador e ativista do Morro da Providência, 77 milhões teriam sido investidos nas obras do teleférico, que ligaria a região à Central, inaugurado em 2014. No entanto, a obra foi executada sem o consentimento da maior parte dos moradores, acabando com uma das quadras que serviam como área de lazer para a população. O equipamento teve seu funcionamento interrompido em 2016 e encontra-se atualmente fora de funcionamento, não tendo previsão de retorno às atividades. Portanto, não foi considerado um sistema de transporte para o local. Vale destacar que, além da quadra esportiva, para que fosse possível viabilizar a construção do teleférico foram realizadas diversas remoções de casas dos moradores.

O critério influencia diretamente a eficiência energética — custo energético com locomoção; a poluição do ar — pois diminui a emissão de gases; e a inclusão e equidade e diversidade - pois áreas em que se pode caminhar têm o potencial de 
promover a interação e a diversidade de usos nos espaços. No que tange à sustentabilidade, a pesquisa considerou que o transporte de massa tem impacto maior do que o percurso de ônibus e menor do que o percurso de transporte não motor.

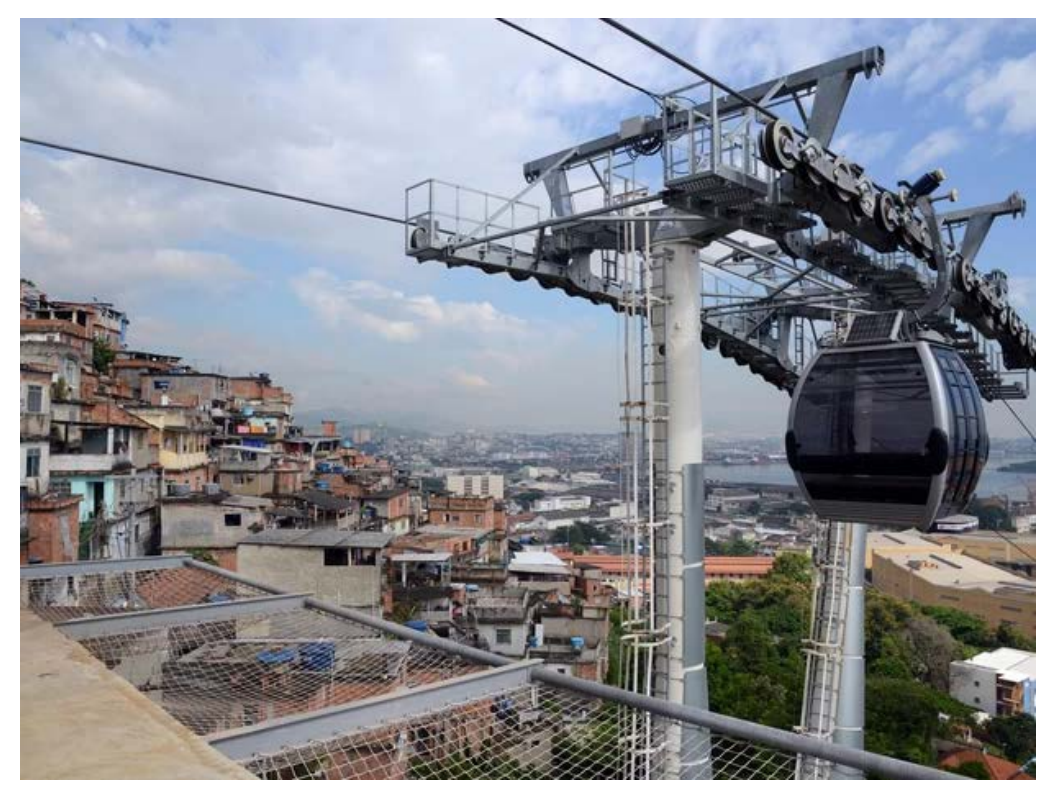

Figura 18 - Teleférico do Morro da Providência.

Fonte: Piniweb. Disponível em: <http://piniweb17.pini.com.br/construcao/infra-estrutura/obra-doteleferico-do-morro-da-providencia-no-rio-de-288488-1.aspxe>. Acesso em: 1으 maio 2019.

\subsubsection{3. \\ Atendimento da área por ciclovias e calçadas que favoreçam o transporte não motor}

Fonte: Mapa de mobilidade (Figura 17).

Conforme mencionado ao longo deste trabalho, a cidade deve priorizar o fluxo de pedestres e veículos não motorizados, em substituição aos automóveis e veículos motores. Promovendo espaços que favoreçam o percurso a pé ou de bicicleta, pode-se obter uma melhoria na eficiência energética, na diminuição da poluição do ar, na aprazibilidade, na diversidade e na inclusão e equidade.

O projeto do Porto Maravilha inclui a construção de um Boulevard pela orla Prefeito Luiz Paulo Conde, com extensa área arborizada e que seria voltada para os pedestres. No primeiro trecho da área estudada, que compreende a Praça Mauá ao Armazém 8 - onde termina o Túnel Marcello Alencar e começa a rodovia Rodriguez Alves —, o percurso tem poucos atrativos para os pedestres, havendo, de um lado, grandes empenas de edifícios, que receberam painéis artísticos, e, do outro, os armazéns de uso privado e que impedem a conexão da via com o cais. O 
segundo trecho do orla tem, em paralelo à Via Binário, uma autopista que impede seu cruzamento e segrega ainda mais a orla do restante da cidade.

Apesar de o trecho contemplar uma ciclovia, a maioria dos entrevistados não a considerou presente. Verifica-se uma grande demanda para uma ciclovia que faça a ligação da Praça Mauá com a Central. Diariamente, são repostas no local cerca de 200 bicicletas privadas, que podem ser alugadas com um plano mensal, a fim de abastecer o fluxo de funcionários que desembarcam diariamente no cais e seguem para a estação Central. Esse caminho, no entanto, não foi contemplado no projeto, que priorizou o percurso turístico.

O projeto incluiu também a construção de uma via de pedestres próxima à Avenida Francisco Bicalho. No entanto, é muito pequena em relação à área total do setor no qual está inserida e não conecta áreas com movimento de pedestres significativo, e, por esse motivo, não foi contemplada.

As áreas atendidas pelo critério foram principalmente as contempladas pelo Boulevard Olímpico e com maior apelo turístico. Os setores com características residenciais receberam poucas melhorias nesse quesito.

O critério influencia diretamente a eficiência energética — custo energético com locomoção; a poluição do ar — pois diminui a emissão de gases; a aprazibilidade - pois locais em que se pode caminhar tornam-se mais agradáveis; e a inclusão e equidade e diversidade - pois áreas em que se pode caminhar têm o potencial de promover a interação e a diversidade de usos nos espaços.

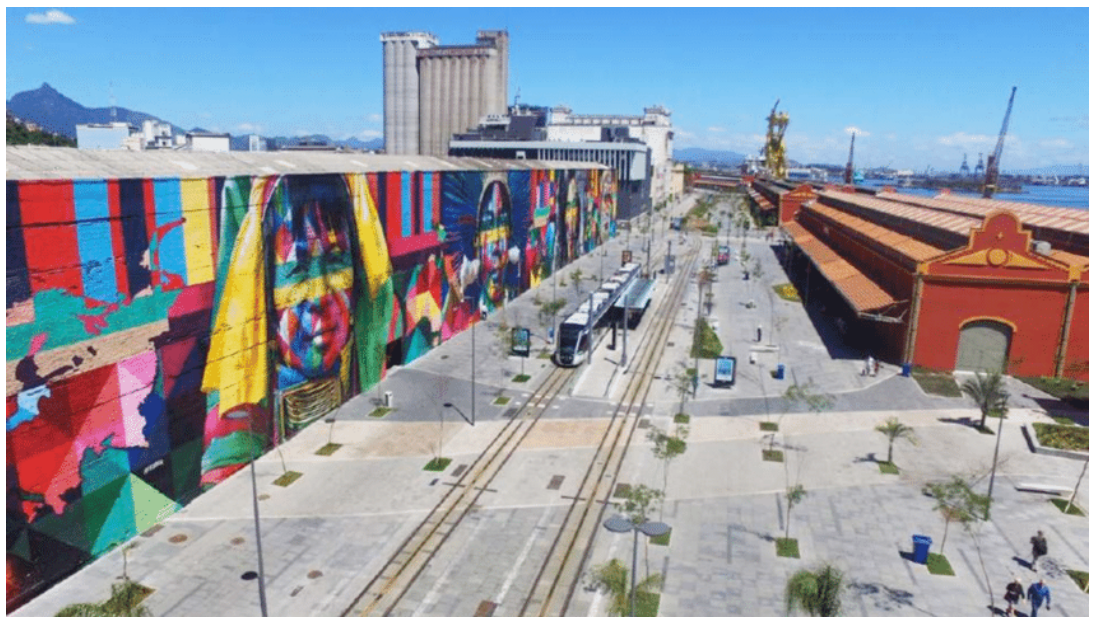

Figura 19 - Imagem do Boulevard Olímpico.

Fonte: Dronestagr. Disponível em: <http://www.dronestagr.am/boulevard-olimpico-rio-de-janeirobrazil/>. Acesso em: 1o maio 2019. 
Apesar de a presença do Boulevard estimular o transporte não motor e, com isso, contribuir positivamente para a eficiência energética, é importante também considerar que, para que fosse viabilizada sua construção, além da demolição da Perimetral, também foi necessário construir o túnel subterrâneo Marcello Alencar. Por estar em local de aterro, recebe constantemente influência direta do lençol freático e para funcionar depende de um sistema de drenagem que conta com quatro bombas com $100 \mathrm{~m}^{3} / \mathrm{h}$ de capacidade, uma cisterna com volume total de $390 \mathrm{mil}$ litros de água e controles de emissão de $\mathrm{CO}_{2} .{ }^{15}$

Portanto, apesar das contribuições positivas promovidas pelos circuitos não motores, é importante também considerar, posteriormente, o custo energético de sua operação como um todo.

\subsubsection{4.}

\section{Redução de vias geradoras de trânsito e ruídos no entorno}

Fonte: Mapa de previsão de ruídos na área (Figura 20).

A presença de vias geradoras de trânsito tem alto impacto na sustentabilidade urbana. Grandes congestionamentos, além de aumentar a emissão de gases responsáveis pelo efeito estufa, aumentando, em consequência, a poluição do ar, também diminuem a aprazibilidade, a inclusão e a eficiência energética da região.

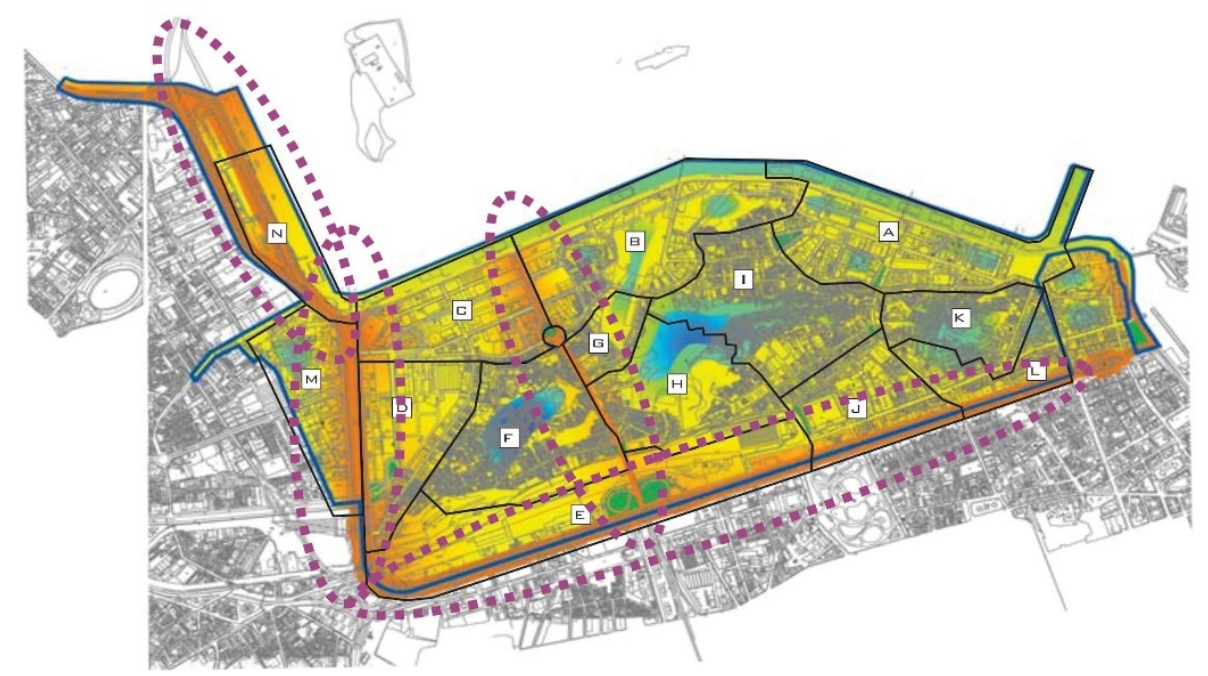

Figura 20 - Mapa de previsão de ruídos na região do Porto Maravilha. Fonte: Elaboração própria. Adaptado do EIV Porto Maravilha.

\footnotetext{
${ }^{15}$ Informações disponíveis em: <http://www.rio.rj.gov.br/web/guest/exibeconteudo?id=6214944>. Acesso em: 3 maio 2019.
} 
A área estudada é cercada por grandes vias com alto fluxo de veículos, como a Presidente Vargas, a Francisco Bicalho, o viaduto de acesso ao túnel Santa Bárbara e a nova a Via Binário. Tais vias prejudicam a sustentabilidade das áreas C, D, E, G, J, L, M e N.

A presença de vias geradoras de trânsito pode influenciar diretamente a eficiência energética - pois demandam maior consumo de energia gasta em congestionamentos; a poluição do ar — pois aumentam a emissão de gases; a aprazibilidade - pois podem promover maior ruído e desgastes urbanos; e a inclusão e equidade - pois a presença de congestionamentos pode segregar o espaço do restante da cidade, além de a poluição sonora ser um transtorno para a população residente.

\subsection{3.}

\section{Ocupação do solo}

Fonte: Mapa de diversidade de usos (Figura 21).

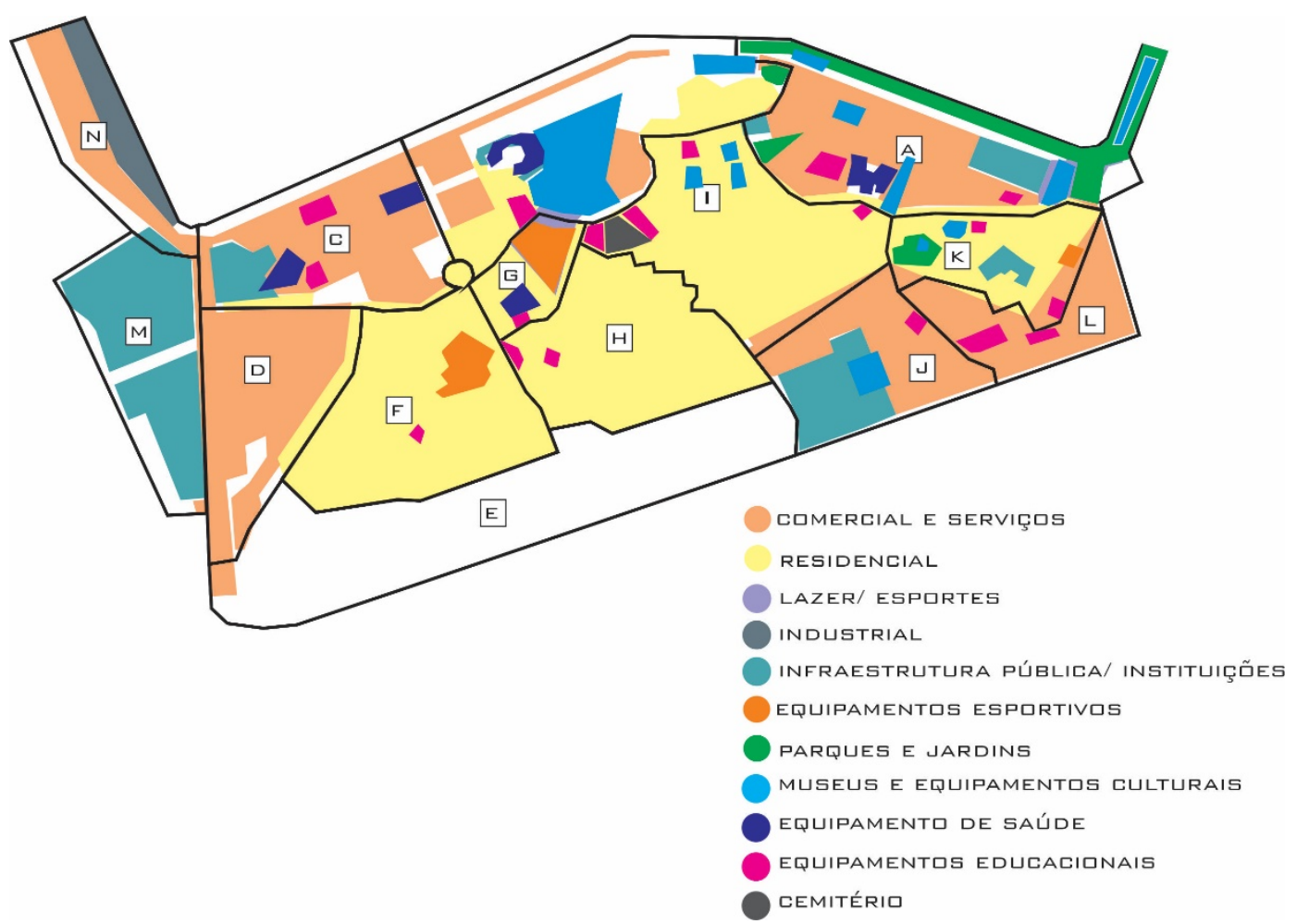

Figura 21 - Mapa de diversidade de usos e equipamentos. Fonte: Elaboração própria.

Diversos autores, como Leite (2012), apontam a cidade compacta como o modelo mais sustentável e eficiente, pois reduz o consumo de energia e a geração 
de gases GEE para a execução de atividades e locomoção. A ideia de eficiência está diretamente ligada à sustentabilidade, ao considerarmos os impactos gerados pela necessidade de locomoção e os custos vinculados às redes de abastecimento necessárias para a infraestrutura e o funcionamento da cidade.

Segundo Acioly \& Davidson (1998), a densidade deve considerar os seguintes aspectos: constituição familiar (número de moradores por unidade), área do assentamento, área dos lotes de acordo com a atividade, área da unidade residencial, taxa de ocupação, índice de ocupação e/ou coeficiente de aproveitamento e área para circulação — logradouros.

A análise dessa categoria compreendeu a elaboração de um mapa com o levantamento dos equipamentos existentes, que foi incluído no mapa de setorização divulgado pela CDURP, pretendendo verificar como é feita a distribuição dos recursos em áreas residenciais e comerciais.

O uso prioritariamente residencial pode aumentar a vitalidade do lugar e evita seu esvaziamento. Ainda de acordo com os autores, outras estratégias podem ser aplicadas para aumentar a eficiência das cidades, como aplicar critérios para incentivar o uso residencial de $60 \%$ da gleba. As dimensões dos lotes e o tamanho das testadas são outros fatores que podem influenciar a dinâmica das cidades. Lotes estreitos são capazes de aumentar a diversidade e estimular o trânsito dos pedestres, no entanto podem ser menos atrativos para o investidor e acabam aumentando o número de construções coladas nas divisas, que são prejudiciais para o conforto ambiental. De outro ponto de vista, lotes muito estreitos podem inviabilizar a construção de grandes empreendimentos, que promoveriam a comercialização de Cepacs. Algumas áreas do projeto do Porto Maravilha delimitaram e restringiram o desmembramento de lotes menores que $1.000 \mathrm{~m}^{2}$ (setores A, B, F, I, J) e $2.000 \mathrm{~m}^{2}$ (C, D, E, M), a fim de assegurar terrenos maiores e mais propícios a grandes construções que fomentem a aquisição de Cepacs. Como incentivo para a formação de lotes maiores, o projeto também contempla a concessão de área adicional de construção, no total de 15\% do valor total remembrado.

Entretanto, os impactos urbanos gerados pela formação de lotes muito extensos não foram contemplados na legislação que definiu os parâmetros supracitados. Conforme mencionado ao longo da pesquisa, lotes muito extensos podem tornar a área menos atrativa para o pedestre e aumentar, entre outros fatores, a sensação de segurança e aprazibilidade do lugar. Como medida para diminuir tais 
impactos, a CDURP solicitou aos grandes empreendimentos, como Trump Towers e Porto Atlântico — ambos atualmente abandonados —, que fossem construídas novas ruas e vias de pedestres no terreno.

Outro fator que pode gerar áreas sem estímulo para a população é o fato de a legislação permitir que não sejam computadas áreas construídas em até 1,5 metro de térreo. Tal possibilidade diminui a interação entre o pedestre e as edificações.

A pesquisa relaciona diretamente o critério ocupação do solo com os princípios eficiência energética, inclusão e equidade e diversidade. $\mathrm{O}$ modelo de ocupação do solo e sua forma interferem diretamente na eficiência e vitalidade das cidades. O planejamento urbano adequado deve considerar a diversidade de usos, priorizando as edificações residenciais, as dimensões de lotes adequadas, que estimulem a circulação do pedestre, e o aumento de densidade adequado, concomitantemente ao investimento em infraestrutura necessária.

O EIV definido para o Porto Maravilha considera o aumento da densidade de algumas regiões do projeto com a ampliação dos gabaritos definidos pelo projeto. No entanto, o estudo apresentando as obras de infraestrutura necessárias para atender à demanda de infraestrutura gerada pelo aumento da densidade, como ampliação do transporte, fornecimento de energia e água, não foi concluído. Uma caixa d’água, que seria capaz de atender à demanda estipulada pela expansão, começou a ser construída no Morro do Pinto; no entanto, a obra não chegou a ser concluída e foi abandonada.

Durante a entrevista, o presidente diretor da CDURP afirmou também que não há qualquer estímulo para a construção de empreendimentos residenciais. A construção do tipo de empreendimento ficaria a critério do empreendedor, sendo ele que definiria o uso residencial ou comercial. O Projeto de Lei n⿳o 109/2009 considera o custo do Cepac em algumas áreas para a construção residencial menor do que o Cepac destinado para a construção comercial, sendo esse o único incentivo promovido pela legislação para estimular esse tipo de uso.

A análise dessa categoria verifica se o projeto considerou o crescimento da densidade junto com o investimento necessário para sua infraestrutura e se a área tem diversidade de usos e equipamentos. 


\subsection{1.}

\section{Adequação do projeto urbano para atendimento do aumento da} densidade prevista pelos Cepacs

Fonte: Mapa de gabaritos propostos para o Porto Maravilha (Figura 15).

De maneira geral, apenas as áreas com recurso destinados aos Cepacs foram contempladas como potenciais. O projeto não previu um possível aumento de demanda por causa da implantação do projeto nas áreas que não têm terrenos destinados à venda dos certificados, ou seja, os setores F a L e N. Também não foi considerado um possível efeito de esvaziamento da região ocasionado pelo aumento do preço dos aluguéis e pela valorização imobiliária.

O critério trabalhado influencia a eficiência energética - pois o aumento da densidade pode promover melhor eficiência e diminuição dos gastos energéticos para a locomoção; e a poluição do ar — pois a diminuição da necessidade de locomoção diária pode diminuir a emissão de gases.

\subsection{2.}

\section{Atendimento da área por usos e equipamentos diversos}

Fonte: Mapa de diversidade de usos (Figura 21).

Para a análise desse critério, foi necessário fazer um levantamento geral dos equipamentos existentes por meio do Google Maps, integrando as informações com a setorização divulgada pela CDURP. Mesmo sabendo que as informações divulgadas pelo Google Maps nem sempre representam a realidade, ele ajuda a ter uma noção da diversidade e da disponibilidade de equipamentos na região.

Segundo o relatório de ocupação e uso do solo da cidade do Rio de Janeiro de 2013, apenas $2 \%$ das áreas licenciadas com mais de $800 \mathrm{~m}^{2}$ eram voltados para habitação na região do Porto Maravilha, entre 2009 e 2013, enquanto 76\% eram destinados ao uso comercial, e $22 \%$, ao uso misto.

Durante a realização das entrevistas, a grande maioria dos moradores reclamou pela falta de mercados na região, entre outros tipos de atividades.

O mapa de diversidade de usos (Figura 21) e equipamentos, elaborado pela pesquisa, indica que a maior concentração de equipamentos está nas regiões mais próximas da orla, que, no entanto, é predominantemente comercial. A única área 
residencial que está próxima aos equipamentos considerados foi a área K, onde se localiza o tradicional Morro da Conceição.

A diversidade de usos e de equipamentos influencia a eficiência energética — pois diminui a necessidade de transportes diários para a realização de atividades; a poluição do ar — pois diminui a emissão de gases com a locomoção; a inclusão e equidade - pois os recursos urbanos distribuídos de forma equitativa promovem o desenvolvimento humano; e a diversidade - pois a mistura de usos e de equipamentos aumenta a diversidade do local.

\subsection{4.}

\section{Arborização urbana}

Fonte: Mapa de arborização urbana (Figura 22).

Herzog define a "infraestrutura verde" como estratégia para reduzir os impactos urbanos causados pelo crescimento das cidades. Segundo a autora, a adoção de uma infraestrutura verde ou ecológica, como é também conhecida, é capaz de mitigar os impactos ambientais e auxiliar na adaptação em caso de eventos climáticos, como aumento de precipitação, formação de ilhas de calor, desertificação e diminuição da biodiversidade (Herzog, 2010).

Ainda segundo a autora, a infraestrutura verde é um conceito emergente, que consiste em redes ecológicas conectadas e intervenções de baixo impacto e alto desempenho, capazes de criar espaços multifuncionais e flexíveis.

A arborização urbana foi relacionada com as dimensões poluição do $a r$, recursos hídricos e aprazibilidade, sendo as duas primeiras por sua função ecológica e a terceira pelo sombreamento e pela sensação de conforto e acolhimento que pode ser proporcionado por ela. Os critérios para a análise do aspecto abordado foram: plantio de novas árvores, preservação das árvores existentes no projeto e previsão de instalação de áreas verdes com função ecológica pelo projeto. Os três critérios abordados têm peso 3, por serem fundamentais para as dimensões relacionadas.

O projeto considerou o plantio de novas árvores ao longo do trecho do Boulevard Olímpico. No entanto, diversas espécies existentes tiveram de ser removidas para viabilizar a obra. Algumas áreas residenciais, apesar de apresentarem um relatório alegando risco de deslizamento, como a Pedra Lisa, não 
têm nenhum programa de rearborização em encostas, apesar de este ser recomendado pelo EIV. O documento elaborado com o EIV para a região também quantificou e verificou o tipo de árvores presentes e identificou que sua arborização não é expressiva. Algumas áreas têm percentual de áreas verdes muito baixo, como o setor I, por exemplo, com apenas 0,05\%. A ONU considera ideal um índice de área verde estimado em $12 \mathrm{~m}^{2}$ para cada habitante. O índice da região verificado pelo EIV foi de 5,27 $\mathrm{m}^{2}$; no entanto, esse valor se deu pelo baixo número de habitantes. Com o aumento da densidade proposto pelo projeto, mesmo que seja aumentado o número de áreas verdes, esse índice se reduzirá ainda mais, pois aumentará também a população existente.

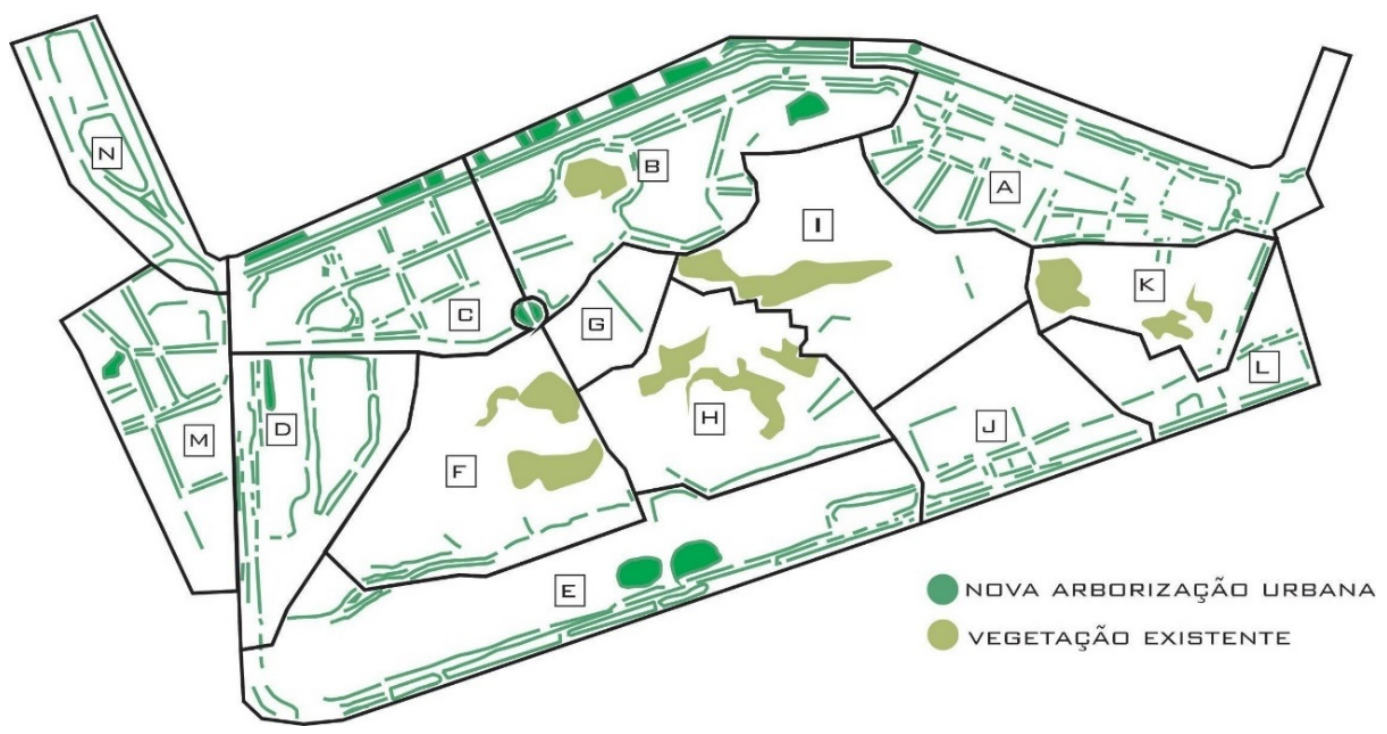

Figura 22 - Mapa de arborização urbana do Porto Maravilha. Fonte: Projetos disponibilizados pela CDURP.

\subsubsection{1.}

\section{Plantio de novas árvores e áreas verdes}

Fonte: Mapa de arborização do Porto Maravilha (Figura 22).

O projeto contemplou novas vias arborizadas, principalmente no Boulevard e nas novas quadras projetadas. No entanto, as áreas verdes projetadas ainda não acompanham proporcionalmente o aumento da densidade. As principais áreas que receberam o plantio de novas árvores foram as áreas da orla turística e as regiões comerciais; as áreas residenciais permaneceram com pequenas áreas de vegetação existente antes e proporcionalmente pequenas em relação à população existente. 
A arborização urbana influencia a eficiência energética - pois ajuda a manter o conforto bioclimático, reduzindo a necessidade de aparelhos de ar condicionado; a poluição do ar — pela captação de carbono; os recursos hídricos — por aliviar o sistema de drenagem e ajudar a manter os lençóis; a aprazibilidade - por garantir o sombreamento e o conforto ambiental, deixando os espaços mais agradáveis; e a diversidade — por aumentar a diversidade biológica.

\subsection{5.}

\section{Infraestrutura - redes de água, esgoto e drenagem}

Fonte: Mapa de infraestrutura do Porto Maravilha (Figura 14).

O projeto urbano deve considerar a distribuição de infraestrutura para seus habitantes de forma eficiente e sem perder a qualidade. $\mathrm{O}$ aumento da densidade previsto pelos novos parâmetros urbanos propostos pelo projeto demanda também mais investimentos com relação ao fornecimento de água e esgoto e drenagem.

A gestão eficiente dos recursos hídricos é fundamental para a sustentabilidade global. Sem água, não há vida nem saúde. A instalação de um sistema de água que seja capaz de atender a toda a área desenvolvida pelo projeto deve ser considerada, e a adequação da rede de esgoto com destinação para tratamento e da rede de drenagem é fundamental para garantir a qualidade e a manutenção dos recursos hídricos para as gerações futuras.

Entre os moradores entrevistados, $76 \%$ não viram melhorias no abastecimento de água e 37\% consideram o serviço atualmente fraco ou ruim. Sobre o abastecimento de esgoto, $73 \%$ acreditam que o serviço não melhorou e 35\% acham-no fraco ou ruim. A pesquisa realizada, portanto, aponta que as obras de infraestrutura realizadas não beneficiam de fato a maior parte da população moradora da região estudada.

Para garantir o abastecimento de água com o crescimento da população na região, foi construída uma caixa d’água no Morro do Pinto onde antes era a quadra esportiva dos moradores. Em contrapartida, para a realização das obras, foi construído no local o Parque Machado de Assis, que conta com quadras e espaços esportivos. Como a obra durou mais de três anos, em um local paralelo foi construída uma quadra provisória. A caixa d’água nunca foi finalizada e está fora de funcionamento. 


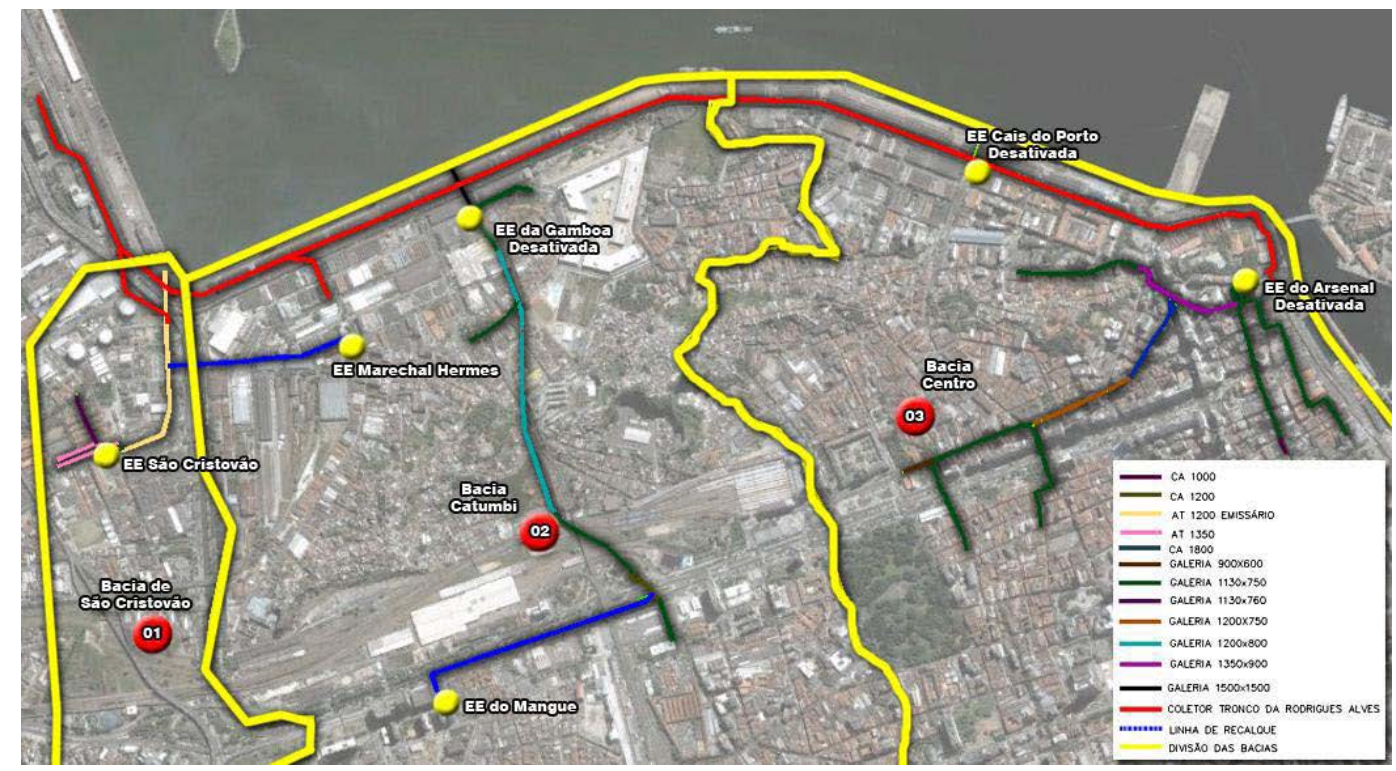

Figura 23 - Situação futura da rede de esgoto e ETE existente na região do Porto Maravilha. Fonte: EIV Porto Maravilha (2013, p. 345).

\subsubsection{1.}

Instalação da rede de água, esgoto e drenagem

Fonte: Mapa de infraestrutura nova do Porto Maravilha (Figura 14).

Esse critério tem como objetivo verificar quais áreas receberam investimento para novas redes de abastecimento de água e esgoto na região e utilizou como ferramenta de análise o mapa de infraestrutura (Figura 14), o qual indica quais vias receberam obras de infraestrutura.

As áreas que receberam a maioria das obras de infraestrutura foram as que receberam o Boulevard Olímpico - A, B e C - e aquelas cujo retorno pelos Cepacs também é maior - $\mathrm{D}$, $\mathrm{M}$ e $\mathrm{N}$.

O critério analisado influencia diretamente os recursos hídricos — pois promove melhor processo de gestão dos recursos ambientais; e a inclusão $e$ equidade - pois promove a melhoria dos serviços para os moradores locais.

\subsubsection{2.}

\section{Aplicação de medidas para evitar alagamentos em regiões urbanizadas pelas chuvas ou elevação do nível do mar}

Fonte: Mapa de áreas alagáveis do Porto Maravilha (Figura 24).

A cidade do Rio de Janeiro passa por constantes alagamentos em períodos de chuva, principalmente por sua geografia e morfologia urbanas. Grande parte da 
região portuária foi construída sobre o aterro, o que aumenta as chances de possíveis alagamentos. Segundo o mapa elaborado a partir dos dados da Surging Seas, foi possível verificar grandes áreas alagáveis pelo aumento do nível do mar ao longo da região. Foram também verificados sete pontos de desaguamento de águas pluviais. Verificou-se durante a pesquisa de campo que, atualmente, a Rua Nabuco de Freitas é uma das que mais alagam durante a ocorrência de chuvas fortes.

Para atestar esse critério, foi elaborado um mapa com as áreas alagáveis junto com as regiões. Comparando-o com a Figura 25, é possível verificar ainda que as áreas de desaguamento de águas pluviais previstas pelo projeto estão localizadas justamente onde há a maior possibilidade de alagamentos.

As regiões localizadas nas áreas com maior relevo — F, H, K (Morros do Pinto, da Providência e da Conceição) e as áreas mais próximas da Presidente Vargas e da Candelária foram aquelas com menos alagamentos durante o período das chuvas por causa do relevo. No entanto, é importante destacar que muitas dessas áreas precisam receber atenção pela possibilidade de deslizamentos, como é o caso da região da Pedra Lisa, no Morro da Providência, onde anteriormente havia 351 casas condenadas pela Defesa Civil por estarem localizadas em áreas de risco.

O critério analisado influencia diretamente os recursos hídricos - pois promove melhor processo de gestão dos recursos ambientais; e a inclusão $e$ equidade - pois promove melhoria dos serviços para os moradores locais.

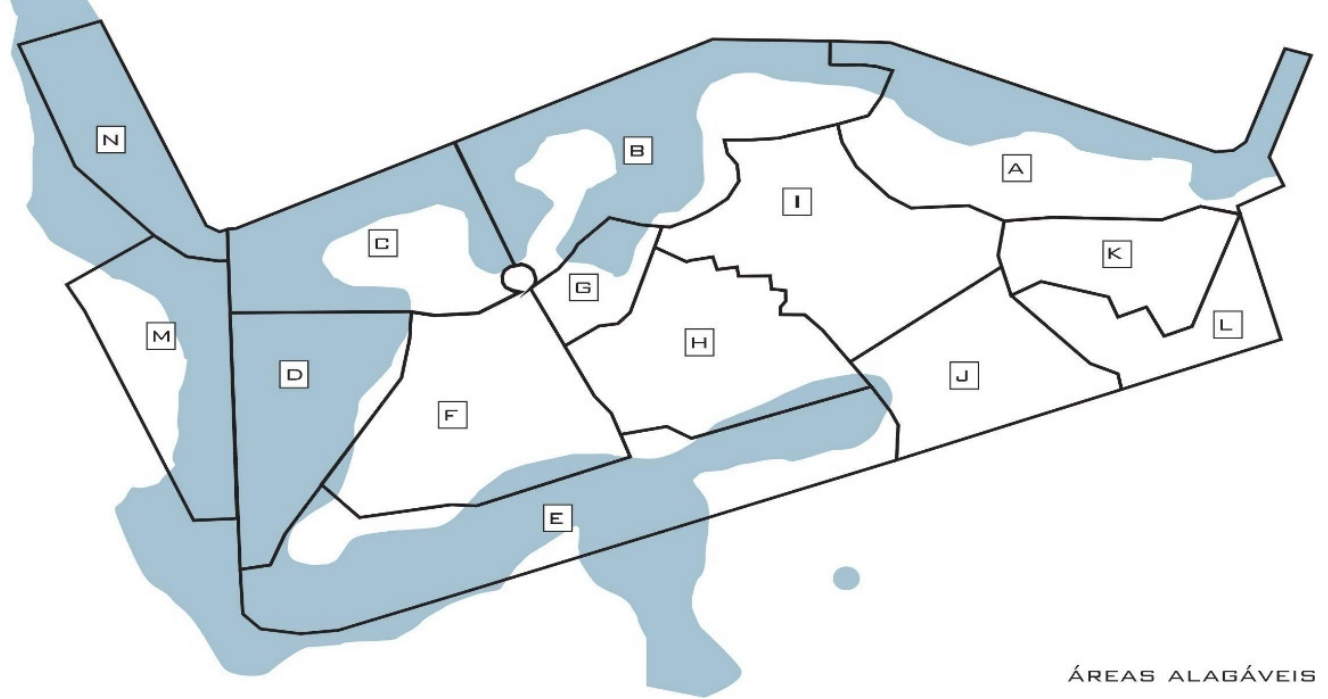

Figura 24 - Áreas alagáveis.

Fonte: Adaptado de Surging Seas. 


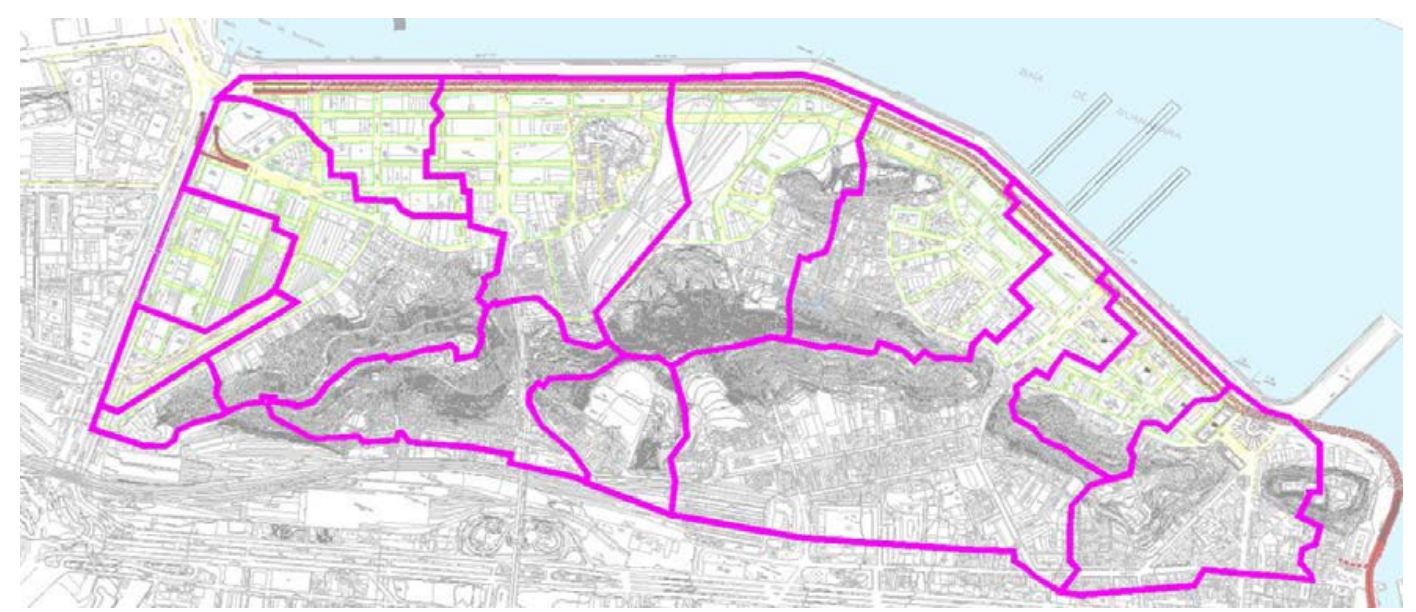

Figura 25 - Situação futura: desaguamento de águas pluviais no Porto Maravilha. Fonte: EIV Porto Maravilha (2013, p. 346).

\subsection{6.}

\section{Gestão dos resíduos sólidos}

Fonte: Levantamento fotográfico no local.

A operação do Porto Maravilha definiu os serviços públicos, como a coleta de lixo, como responsabilidade do consórcio Porto Novo. Por causa da falta de liquidez dos Cepacs, conforme relatado pelo presidente da CDURP durante entrevista, o serviço de coleta foi repassado para a Comlurb. Segundo relato dos moradores e entrevista realizada com alguns proprietários de estabelecimentos da região próxima à Pedra do Sal, como Thiago, um dos administradores do bar e restaurante Armazém 04, localizado no Largo da Prainha, apesar de a coleta ser regular, a mudança na disposição do lixo tornou-se um transtorno para o espaço, já que foram retiradas as lixeiras que ficavam no local e o lixo atualmente acaba ficando disposto na calçada.

\subsubsection{1.}

\section{Redução do acúmulo de lixo nas calçadas}

Fonte: Levantamento fotográfico no local.

A maioria dos entrevistados afirmou que a coleta de lixo acontece com frequência atualmente; no entanto, foi possível identificar durante as visitas que alguns locais tinham um acúmulo maior de resíduos pelas calçadas, gerando diversos transtornos para os moradores. A metodologia de análise desse critério, portanto, foi a partir da percepção e do registro fotográfico realizado durante o trabalho de campo. 
Foi possível verificar durante as visitas de campo que as regiões do Boulevard e das áreas mais urbanizadas recebem mais atenção no quesito apresentado. A área do Morro da Providência e próxima à Central do Brasil apresentou diversos pontos com acúmulo de lixo ao longo dos dias nos quais foi executado o trabalho de campo.

O critério analisado influencia diretamente os recursos hídricos - pois promove melhoria do processo de gestão dos recursos ambientais; e a inclusão $e$ equidade - pois promove melhoria dos serviços para os moradores locais.

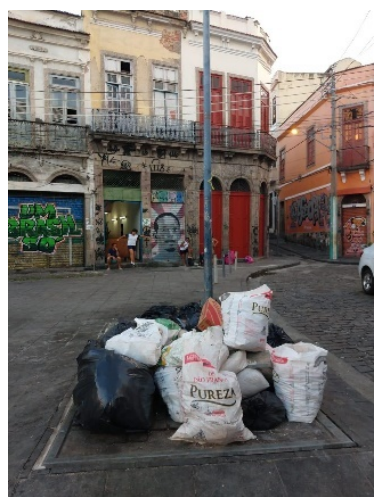

Figura 26 - Acúmulo de lixo no largo São Francisco da Prainha.

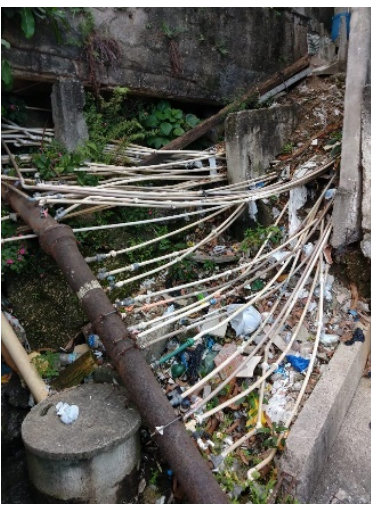

Figura 27 - Acúmulo de lixo no Morro da Providência.

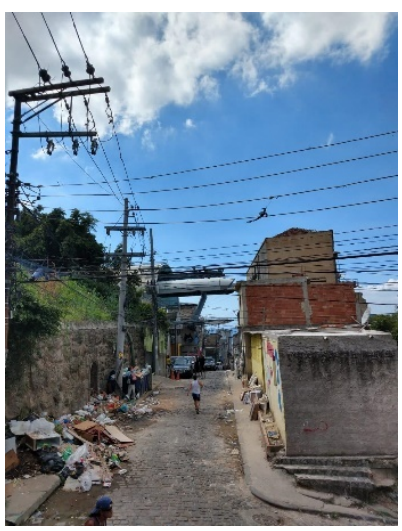

Figura 28 - Acúmulo de lixo e entulho no Morro da Providência próximo à escadaria. 


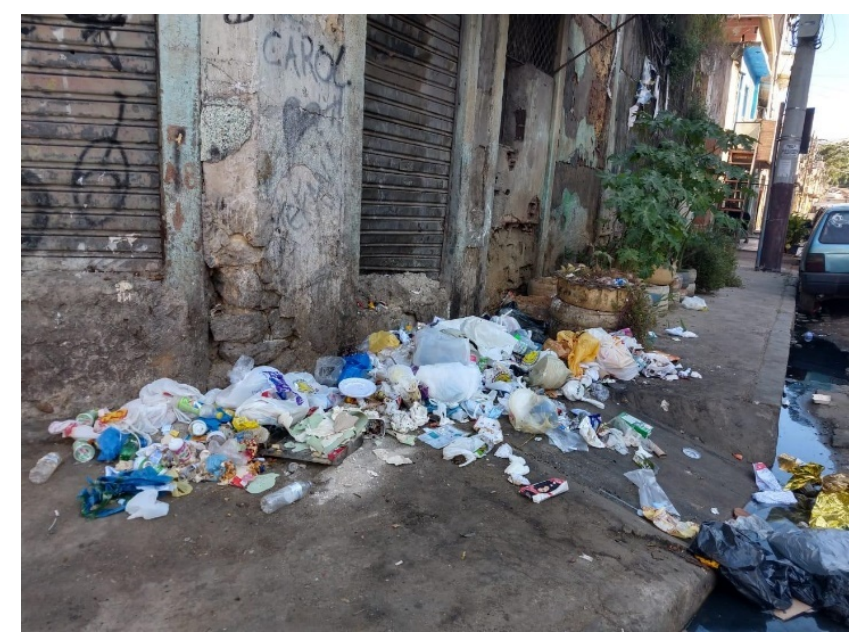

Figura 29 - Acúmulo de lixo próximo à Central do Brasil.

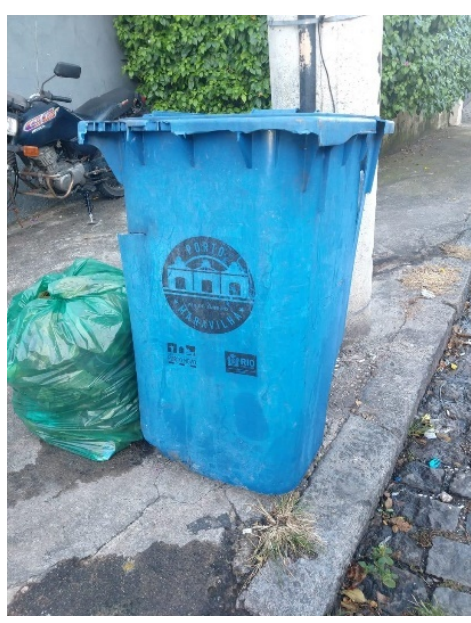

Figura 30 - Coleta de lixo no Morro do Pinto.

\subsubsection{2.}

Instalação de lixeiras no mobiliário e para a coleta seletiva

Fonte: Levantamento fotográfico no local.

Algumas regiões apontam uma melhor disposição de equipamentos públicos que outras ao longo da área de estudo. No que tange à disposição de lixeiras, foi possível verificar que o equipamento do Porto Novo distribuído tem melhor conservação nas áreas do Boulevard, do novo Porto Olímpico - D e M - e do Morro do Pinto, tendo em algumas dessas, inclusive, algumas lixeiras para reciclagem e outras distribuídas em postes.

A coleta de lixo e a reciclagem influenciam diretamente os resíduos sólidos. 


\subsection{7. \\ Preservação e valorização do patrimônio}

Acselrad (2009) define as questões relacionadas com a identidade e a cultura como parte da categoria "patrimônio", vinculada à matriz discursiva "qualidade de vida”. O sentido de patrimônio dado pelo autor não se refere unicamente à materialidade da cidade e de seus edifícios, mas inclui também a capacidade de manter a existência simbólica de lugares construídos ou naturais. Para o autor, essa perspectiva insere-se tanto pelo fortalecimento do sentimento de pertencimento quanto pela construção simbólica de uma imagem que promova o espaço, aumentando sua capacidade competitiva no mercado global.

A região portuária tem grande relevância histórica para a cidade do Rio de Janeiro. Recentemente, a região do Cais do Valongo, junto com o Circuito de Herança Africana, tornou-se Patrimônio da Humanidade pela Unesco. A arquiteta Claudia Escarlate, professora da PUC-Rio e responsável pela gestão dessa área, reafirmou durante a entrevista a importância desse local para o fortalecimento cultural da região.

Outras instituições relevantes para a cultura, como o IPN, também não recebem apoio da região para seu funcionamento, apesar do grande valor para a história de toda a região. Segundo Greice, bisneta de Tia Ciata - importante personalidade histórica da resistência negra e do samba —, o único apoio recebido pela CDURP foi a concessão do imóvel onde hoje se localiza a sede da Casa da Tia Ciata, que realiza diversas atividades culturais gratuitas para os moradores.

\subsubsection{1.}

Valorização do patrimônio arquitetônico com presença significativa de imóveis tombados/preservados

Fonte: Mapa de áreas de preservação e conservação arquitetônica e arqueológica (Figura 31).

A análise do critério foi realizada a partir do levantamento da localização dos imóveis tombados e preservados destacados no EIV de acordo com cada região de projeto. De acordo com o mapa elaborado na Figura 31, foi possível verificar maior presença de imóveis com relevância patrimonial nas áreas A, G, I, J, K e L.

A elaboração da pesquisa considerou a influência do critério apresentado com a identidade e cultura — pois resgatam a importância histórica; e a diversidade - 
pois espaços mais diversos apresentam também suas rugosidades e marcas históricas existentes no lugar.

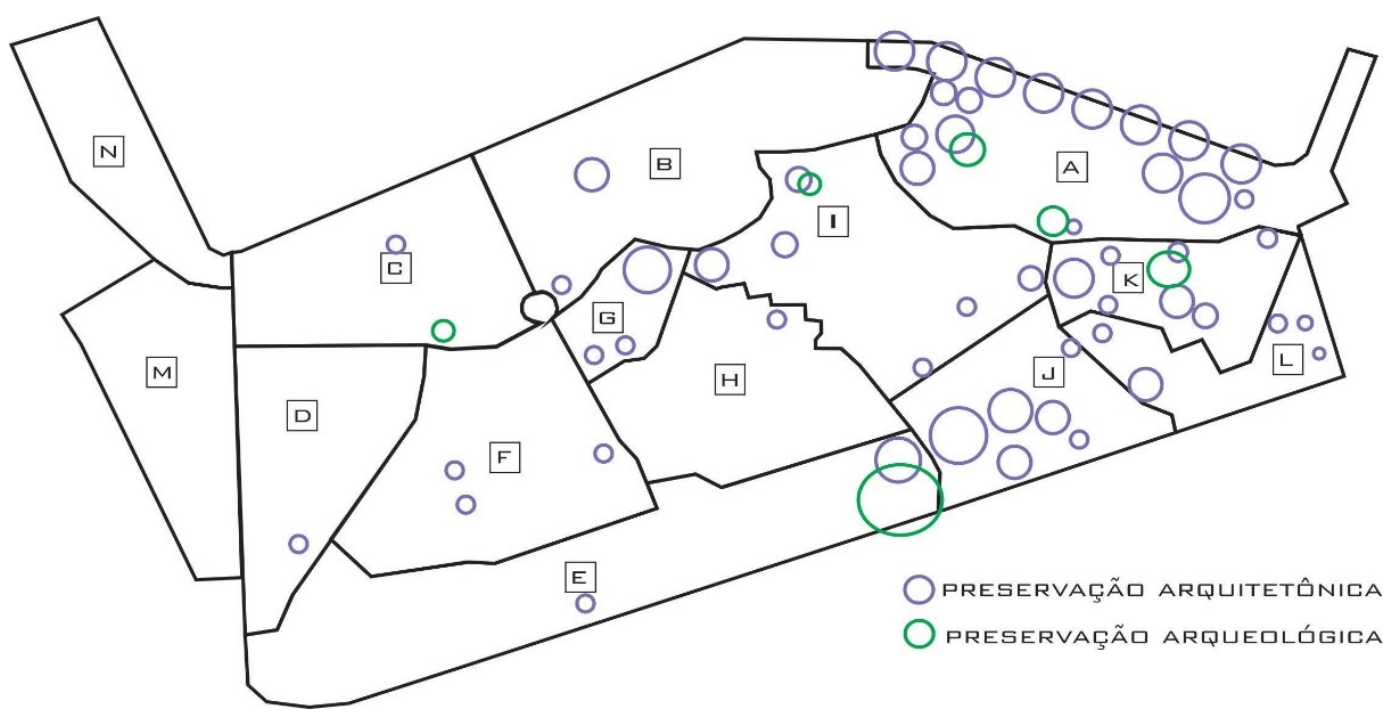

Figura 31 - Mapa de áreas de preservação e conservação arquitetônica e arqueológica. Fonte: Elaboração própria. Adaptado do EIV Porto Maravilha (2013).

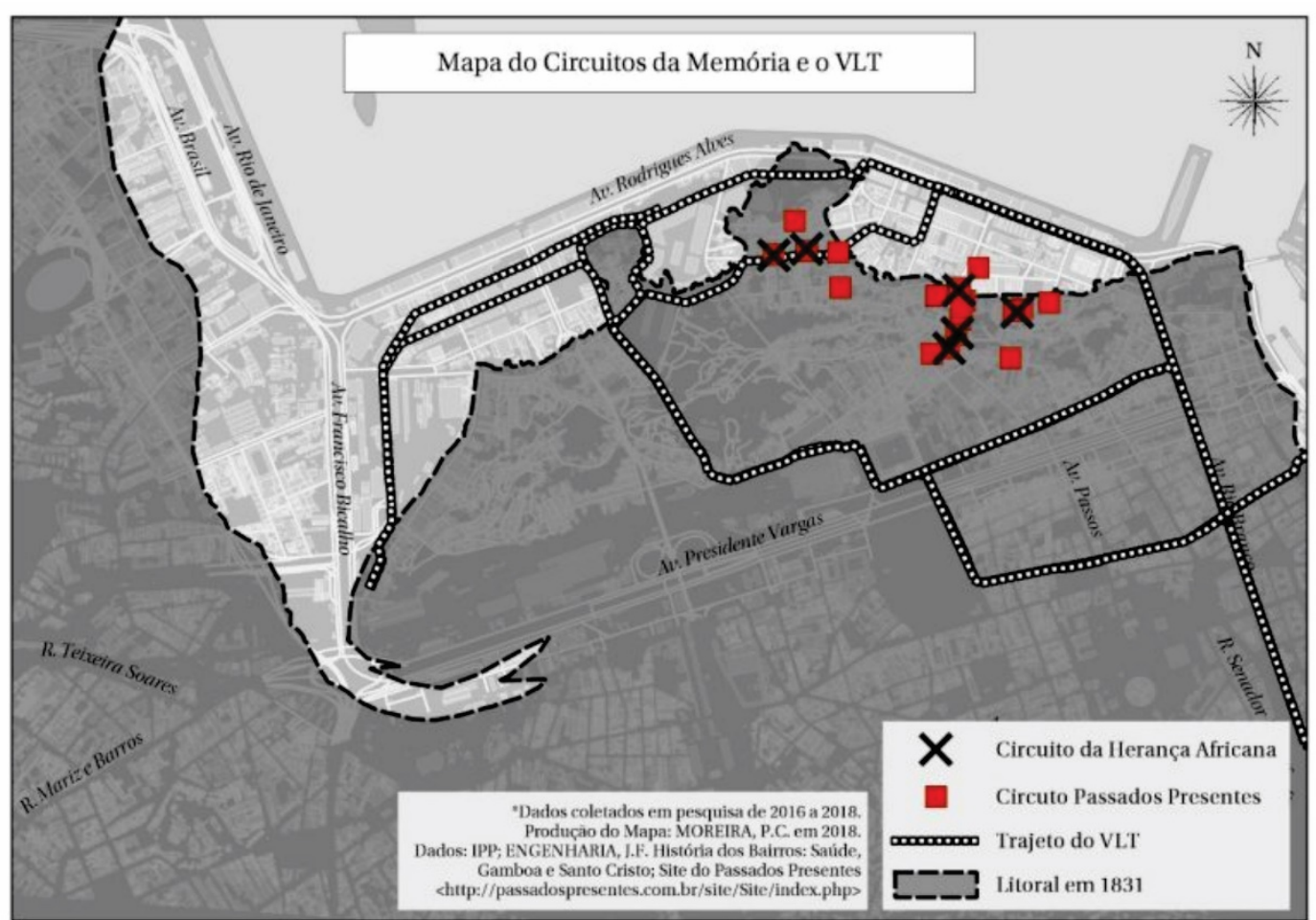

Figura 32 - Circuito da Herança Africana.

Fonte: <http://passadospresentes.com.br/site/Site/index.php>. Acesso em: 2 maio 2019. 


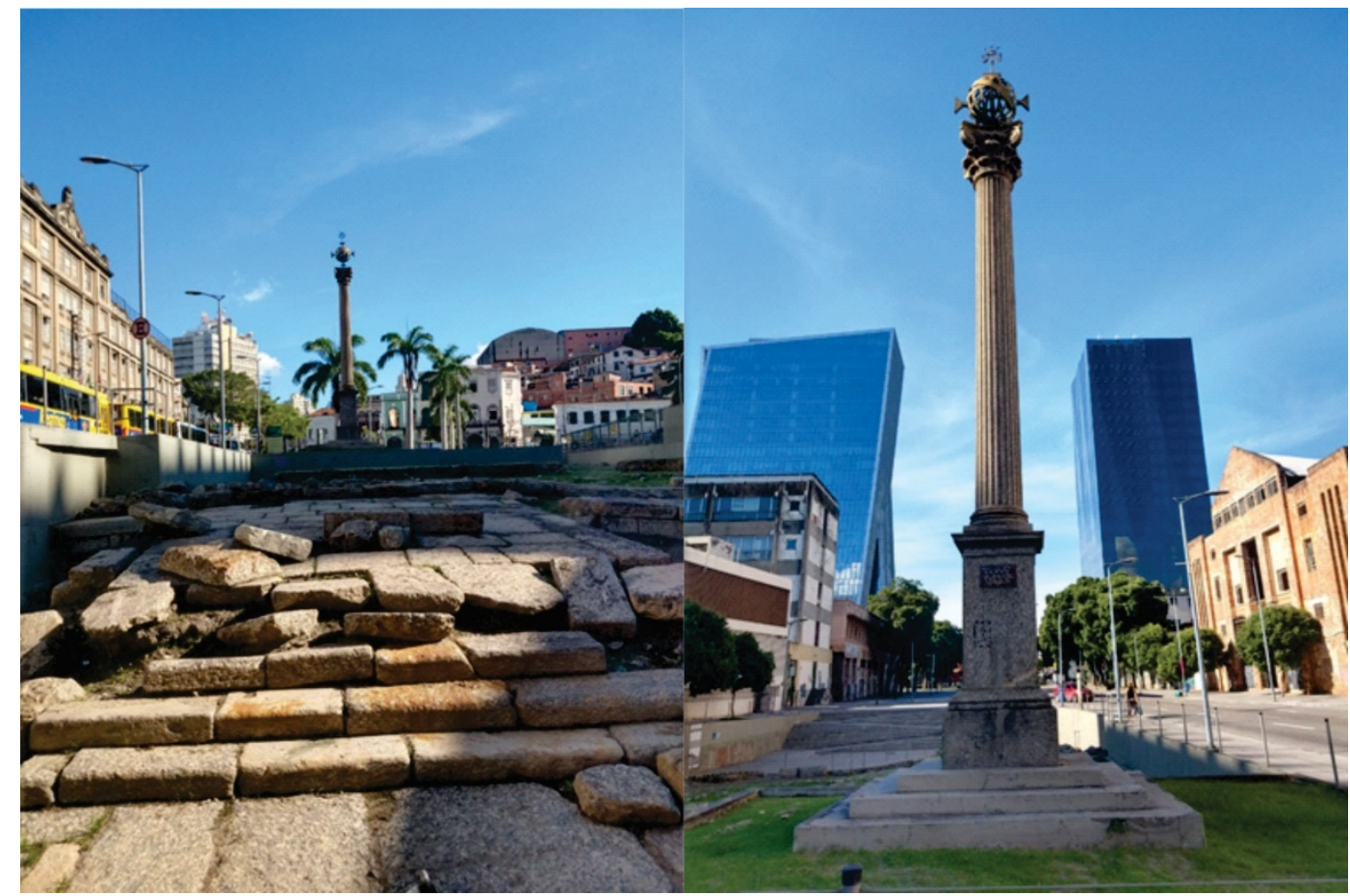

Figura 33 - Cais do Valongo/Imperatriz.

\subsubsection{2.}

\section{Valorização e preservação de áreas arqueológicas}

Fonte: Mapa de áreas de preservação e conservação arquitetônica e arqueológica, patrimônio, arquitetura e preservação arqueológica (Figura 31).

De acordo com o mapa elaborado baseado na lista de áreas arqueológicas presentes na região realizada pelo EIV, foi possível verificar a presença de seis áreas de preservação arqueológica: (a) Sítio São Francisco da Prainha — região K; (b) Sítio Cemitério da Gamboa - região I; (c) Sítio Posto de Abastecimento de Combustíveis do Santo Cristo - região C; (d) Sítio Metropolitano do Rio de Janeiro - Central do Brasil — região E. Também foi incluído na análise como importante área de relevância arqueológica o local onde é atualmente (e) o IPN e o (f) Cais do Valongo - região A.

Conforme relatado durante entrevista com a gestora do IPN, Rachel, filha de Ana Maria de la Merced — fundadora do Instituto — , durante a execução das obras do VLT também foi descoberto outro local de grande relevância arqueológica próximo à Igreja Santa Rita, onde seria o cemitério de escravos mais antigo. Por muitos anos, a comunidade reivindicou que a área fosse protegida; no entanto, atualmente, o local abriga uma das estações de VLT da linha 3. 
A elaboração da pesquisa considerou a influência das áreas de preservação arqueológica com a identidade e cultura — pois resgatam a importância histórica; e a diversidade - pois espaços mais diversos apresentam também suas rugosidades e marcas históricas existentes no lugar.

\subsection{8. \\ Áreas de cultura e lazer}

Fonte: Mapa de diversidade de usos e equipamentos (Figura 21).

Conforme relatado pelo engenheiro Antônio Carlos, diretor da CDURP, e divulgado pela própria companhia, 3\% do valor arrecadado com os Cepacs deveriam ser destinados para projetos culturais voltados para a região, de acordo com a Lei $\mathrm{n}^{\mathrm{0}}$ 101/2009. No entanto, ainda de acordo com a entrevista realizada na Companhia, 75\% desse valor teriam sido destinados pelo então prefeito da época, Eduardo Paes, para a execução da museologia do Museu do Amanhã e do MAR. Em carta aberta divulgada pela Associação da Comunidade Remanescente do Quilombo da Pedra do Sal (Arqpedra), ${ }^{16}$ Damião, um dos líderes da Arqpedra, reivindica que os recursos não foram destinados para equipamentos culturais que realmente envolvessem a comunidade.

Um dos exemplos que foi possível observar durante o trabalho de campo foi a sede do grupo cultural Filhos de Gandhi, localizada próximo à Praça dos Estivadores e dos Jardins do Valongo. Foi possível verificar durante as visitas de campo que o local onde o tradicional grupo de percussão realiza suas atividades está em péssimo estado de conservação e não recebeu apoio para reformar as instalações. Próxima à Praça da Harmonia, a Cia de Mystérios foi uma dos locais que receberam apoio da CDURP para a reforma. Segundo uma de suas sócias, a CDURP realizou a obra da substituição do telhado do imóvel, o que não seria possível ter sido feito sem o apoio. Ainda segundo ela, durante o período muitas pessoas não conseguiram acessar o recurso, pois não tinham conhecimento para realizar o procedimento burocrático que ele exigia. Ela ainda contou que outros estabelecimentos que existiam no local acabaram fechando, pois não sobreviveram à queda de fluxo que aconteceu na região durante o período das obras do VLT, que se alongaram por três anos, como foi o caso da pensão muito antiga de um português próxima à região. Ela também afirmou que

\footnotetext{
${ }^{16}$ A carta aberta foi divulgada na página oficial da Arqpedra no Facebook.
} 
ele apenas queria isenção de impostos, não concedidos para aquela área. Vale destacar que em outras áreas, como no Morro da Conceição, a maior parte dos imóveis conseguiu a isenção de imposto até 2025, conforme descrito durante entrevista pelo engenheiro civil Jorge, que mora na região desde que nasceu.

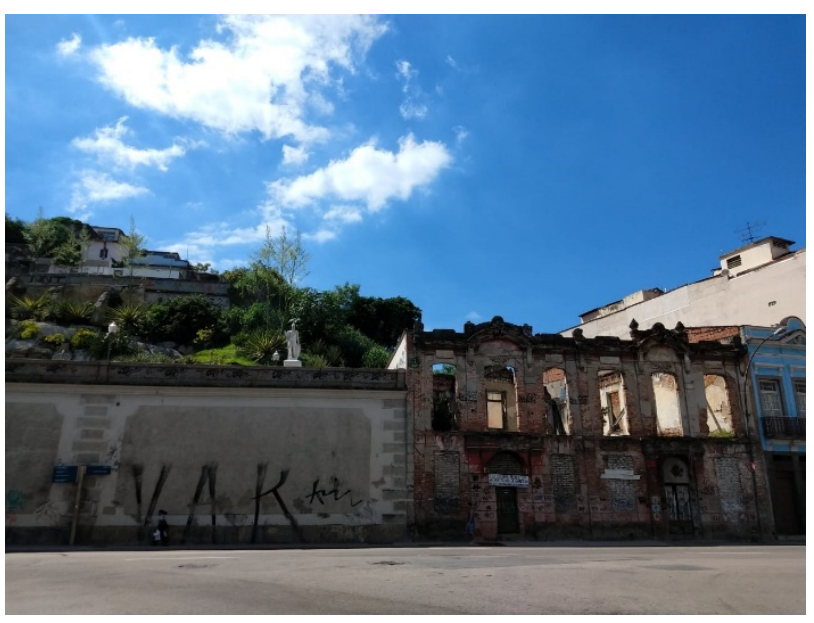

Figura 34 - Fachada da sede do projeto Filhos de Gandhi ao lado dos Jardins do Valongo.

Por meio do trabalho de campo, foi possível constatar que a maior parte dos moradores não utiliza os museus construídos na área próxima à Praça Mauá. De acordo com o levantamento realizado, $46 \%$ dos moradores entrevistados nunca visitaram nem o Museu do Amanhã nem o MAR, e 19\% foram somente uma única vez a um desses equipamentos. A pesquisa aponta que a grande maioria dos moradores, portanto, não costuma frequentar os museus construídos. Já o Parque Olímpico, segundo os entrevistados durante a pesquisa qualitativa, é bastante frequentado pela população local. Cosme, morador do Morro da Providência, e Sérgio, do Morro do Pinto, afirmaram que grande parte dos moradores frequenta o espaço esportivo construído e que são oferecidas aulas gratuitas aos moradores da região que se inscreverem em uma de suas atividades, como aulas de natação, hidroginástica, entre outras.

\begin{tabular}{|c|c|c|c|c|c|c|c|}
\hline \multicolumn{2}{|c|}{ Já foi ao Museu do Amanhã elou MAR? } \\
\hline & & \multicolumn{2}{|c|}{ TOTAL } & \multicolumn{2}{c|}{ MORADORES } & \multicolumn{2}{c|}{$\begin{array}{c}\text { NÃO } \\
\text { MORADORES }\end{array}$} \\
\cline { 2 - 8 } & Resultado & n. & $\%$ & n. & $\%$ & n. & $\%$ \\
\hline \multirow{3}{*}{$\begin{array}{c}\text { Já foi ao Museu } \\
\text { do Amanhã e/ou } \\
\text { MAR? }\end{array}$} & Nunca & 52 & $39 \%$ & 25 & $46 \%$ & 27 & $35 \%$ \\
\cline { 2 - 8 } & 1 vez & 31 & $23 \%$ & 10 & $19 \%$ & 21 & $27 \%$ \\
\cline { 2 - 8 } & Mais de 3 vezes & 16 & $12 \%$ & 6 & $11 \%$ & 10 & $13 \%$ \\
\hline
\end{tabular}

Tabela 3 - Entrevistas no local. Frequência no Museu do Amanhã ou no MAR. Fonte: Elaboração própria. 


\subsubsection{1.}

\section{Atendimento da área por praças, centros esportivos e áreas de lazer com infraestrutura}

Fonte: Mapa de diversidade de usos e equipamentos (Figura 21).

Por meio da análise do projeto divulgado para o Porto Maravilha e da visita da campo, foi possível verificar que as principais áreas com intervenções em praças e áreas de lazer foram o Boulevard Olímpico - áreas A e B; o Parque Machado de Assis (caixa d’água do Morro do Pinto) — região F; o Parque Olímpico — região G; e o Mirante do Valongo — região K.

Vale a pena destacar que outras áreas consolidadas pela população local, como o Morro da Providência, tiveram suas poucas áreas culturais e de lazer removidas, apesar da grande demanda dos moradores por áreas de lazer. Conforme destacado pela carta aberta formulada pelo Fórum Comunitário do Porto, a quadra esportiva existente na favela mais antiga da cidade do Rio e muito utilizada por seus moradores como local de encontro foi removida para a construção do teleférico — que não está em funcionamento desde dezembro de 2016 — , e nenhum outro equipamento foi construído na região para substituí-la. Durante a visita de campo, foi possível verificar atividades em locais improvisados, como aulas de dança e crianças jogando bola nas ruas próximas às escadas onde antes havia a quadra utilizada.

Já o Parque Machado de Assis, localizado no Morro do Pinto, é bastante frequentado pela população, tendo, além de duas quadras, equipamentos de ginástica, pergolado, espaço para aula de lutas marciais e área para a realização de festas entre os moradores. No entanto, a falta de manutenção é um item que preocupa parte dos entrevistados no local. Foi possível verificar durante a visita áreas onde a grama sintética já havia descolado e a grade de proteção encontravase solta, além de algumas paredes descascadas na área da churrasqueira.

A presença de praças, parques e áreas de lazer com infraestrutura influencia principalmente a aprazibilidade - pois áreas com praças e parques são mais agradáveis para a população; a identidade e cultura — pois geram maior sensação de pertencimento; a inclusão e equidade - pois a disposição de equipamentos de lazer de forma equitativa torna os espaços mais inclusivos; e a diversidade — pois promove maior diversidade de usos e de vida no local. 
Ũ

Figura 35 - Parque Olímpico — vista do Mirante da Providência Fonte: Autora.

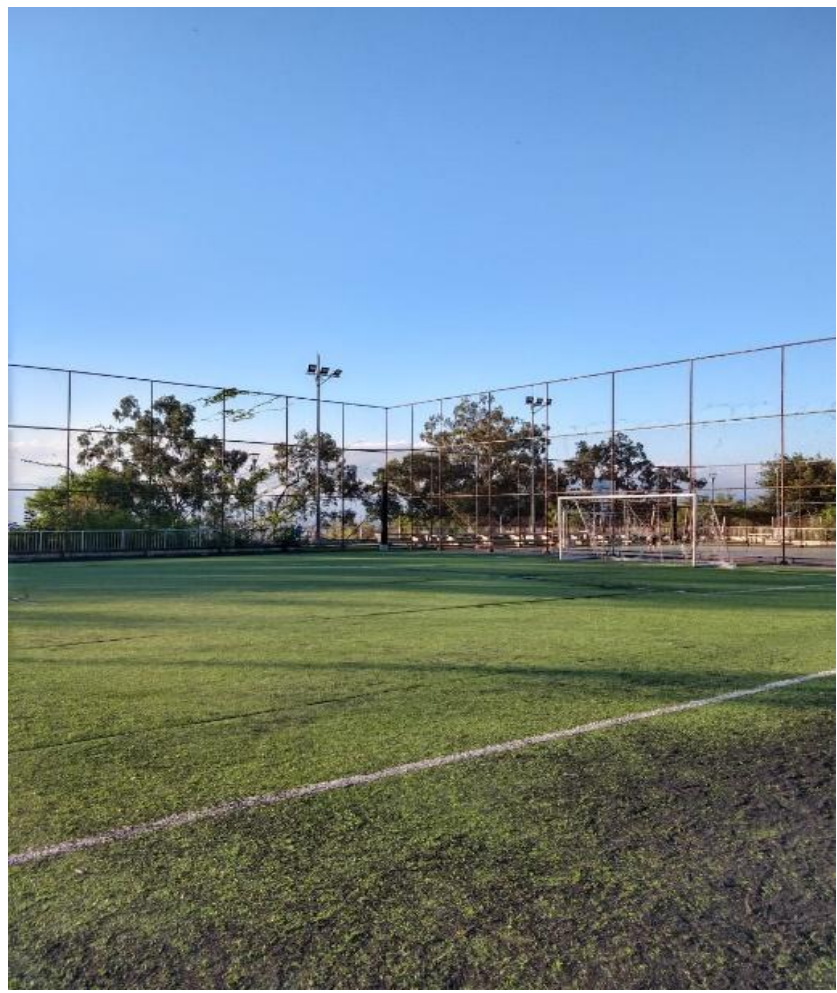

Figura 36 - Parque Machado de Assis. 


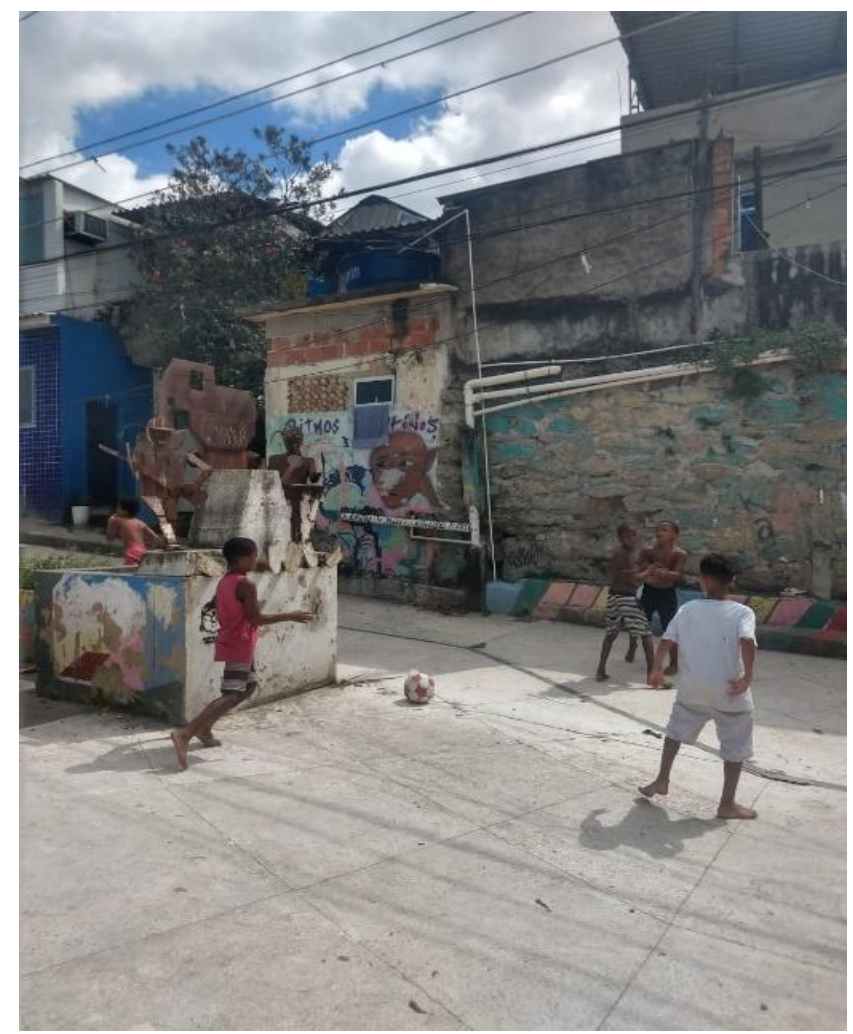

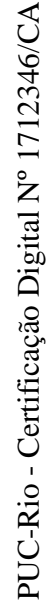

Figura 37 - Área antiga da quadra do Morro da Providência.

Figura 38 - Parque Machado de Assis, com área de lazer e esporte. 
Figura 39 - Jardim do Valongo.

\subsubsection{2.}

Atendimento de áreas por museus e centros culturais Fonte: Mapa de equipamentos e usos (Figura 21).

As áreas culturais e de lazer propostas pelo projeto do porto foram o Museu do Amanhã e o MAR — região A; o AquaRio — região B; a revitalização da Praça Harmonia — região B; o Centro Cultural José Bonifácio, que atualmente tem como intuito preservar a herança negra —região I; e o Mirante do Valongo, que recebe também o observatório de astronomia da Universidade Federal do Rio de Janeiro (UFRJ) - região K.

A construção dos museus localizados próximo à Praça Mauá não estava prevista no projeto inicial do Porto Maravilha, conforme relatado inclusive pela entrevista realizada com o presidente da CDURP. Segundo Antônio Carlos, para que fosse viabilizada sua construção, o então prefeito Eduardo Paes destinou 380 milhões que estavam previstos para obras de urbanização do Morro da Providência e do Morro do Pinto (Anexo 3). A obra do Museu do Amanhã teria custado, em média, 215 milhões, e a revitalização do MAR, 79 milhões. Entre o total de entrevistados no local — tanto moradores quanto pessoas de outros bairros —, 39\% afirmaram nunca terem ido a nenhum dos dois museus (Tabela 3).

A presença de museus e centros culturais influencia diretamente a aprazibilidade - pois áreas com praças e parques são mais agradáveis para a população; a identidade e cultura — pois geram maior sensação de pertencimento; a inclusão e equidade - pois a disposição de equipamentos de lazer de forma 
equitativa torna os espaços mais inclusivos; e a diversidade — pois promovem maior diversidade de usos e de vida no local.

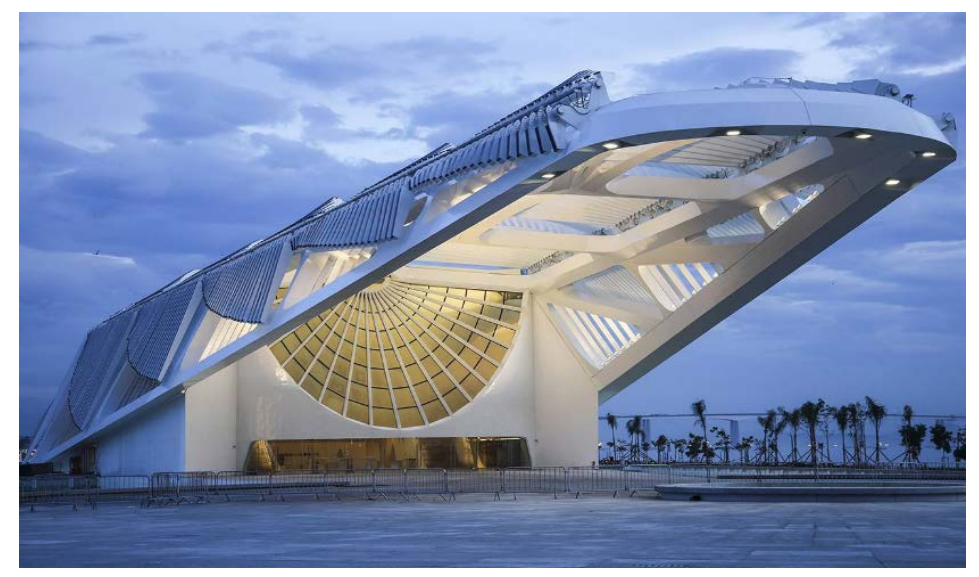

Figura 40 - Museu do Amanhã.

Fonte: <https://museudoamanha.org.br/pt-br/content/hor\%C3\%A1rio-de-funcionamento>. Acesso em: 26 abr. 2019.

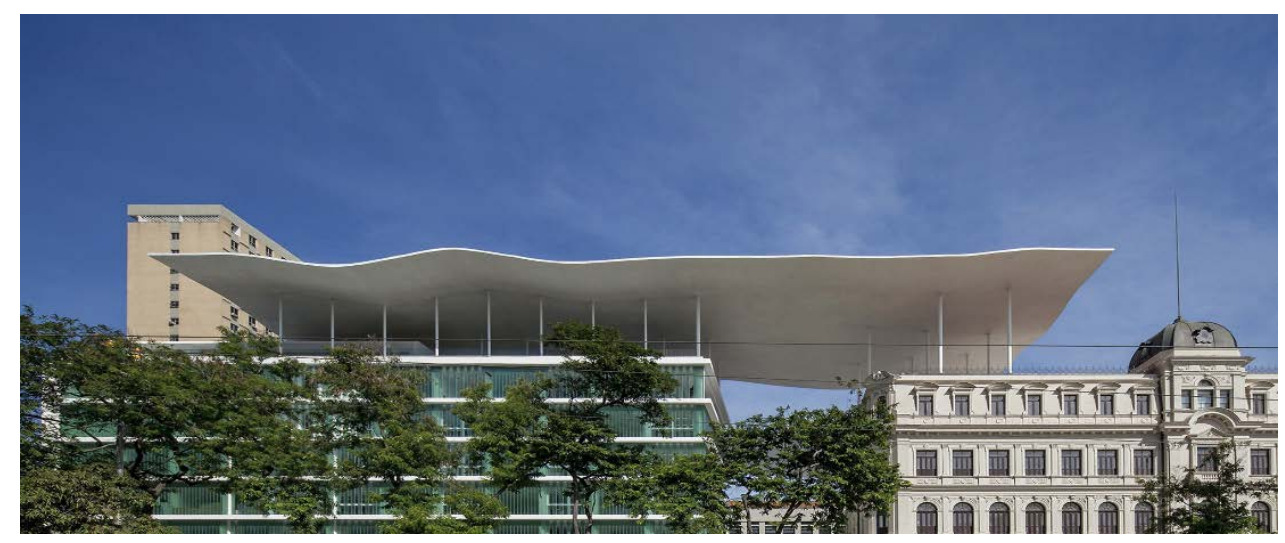

Figura 41 - Museu de Arte do Rio (MAR).

Fonte: <https://www.archdaily.com.br/br/01-108254/mar-museu-de-arte-do-rio-bernardes-jacobsenarquitetura>. Acesso em: 26 abr. 2019.

\subsection{9.}

\section{Acessibilidade}

Fonte: Projeto disponibilizado pela CDURP.

A acessibilidade pode ser considerada condição fundamental para alcançar a sustentabilidade. Tendo em vista que o desenvolvimento sustentável baseia-se, principalmente, em atender às demandas da geração atual sem comprometer os recursos necessários para que as gerações futuras possam atender às suas próprias demandas - conforme destacado pelo Relatório de Brundtland e mencionado anteriormente no trabalho —, é fundamental garantir espaços acessíveis e inclusivos que satisfaçam as necessidades da população. 
De acordo com Borges (2014), segundo pesquisa realizada pelo Censo, no Brasil cerca de $24 \%$ da população afirmaram ter algum tipo de deficiência. Tal fato indica a importância de construir projetos que sejam adaptados à realidade de todos os cidadãos.

A Lei n⿳o 10.098/2000 determina parâmetros básicos para o projeto de calçadas e equipamentos acessíveis, incluindo dimensões de calçadas, passeios, entre outros. O projeto indica a necessidade de instalação de piso tátil, além de rampas e larguras mínimas para a circulação de cadeirantes.

Infelizmente, muitos projetos até hoje são realizados priorizando o trânsito em detrimento do pedestre, principalmente aquele com alguma restrição. Como resultado, muitas vezes temos calçadas estreitas e em mau estado de conservação, para que a via de automóveis possa comportar mais uma faixa de rolamento ou estacionamento. 


\subsubsection{1.}

\section{Atendimento de espaços públicos acessíveis}

A análise desse critério foi feita com base nos projetos apresentados pela CDURP e divulgados no site. Foi possível identificar que em algumas regiões o projeto apresenta incoerências com relação às diretrizes propostas para a acessibilidade universal, como é o caso das áreas.

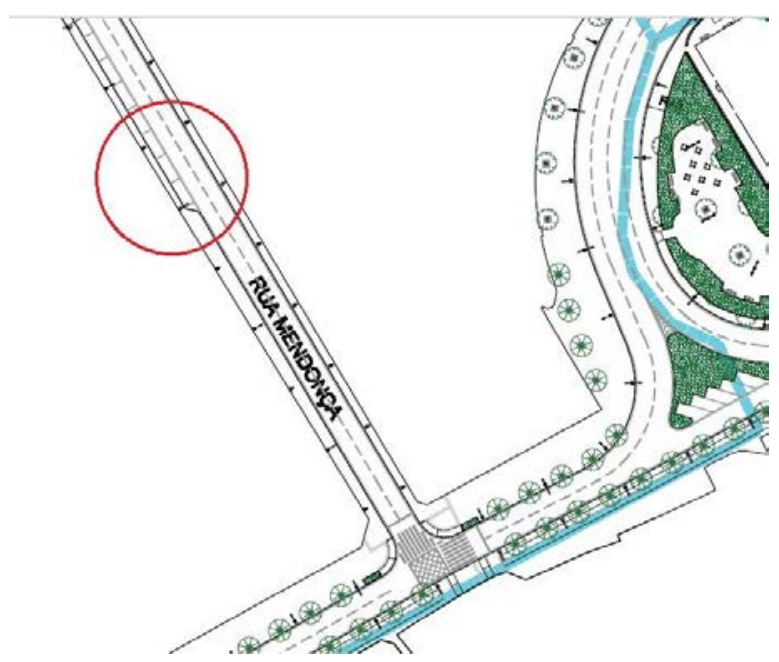

Figura 43 - Calçada estreita, impossibilitando a acessibilidade — setor C. Fonte: Projeto CDURP.

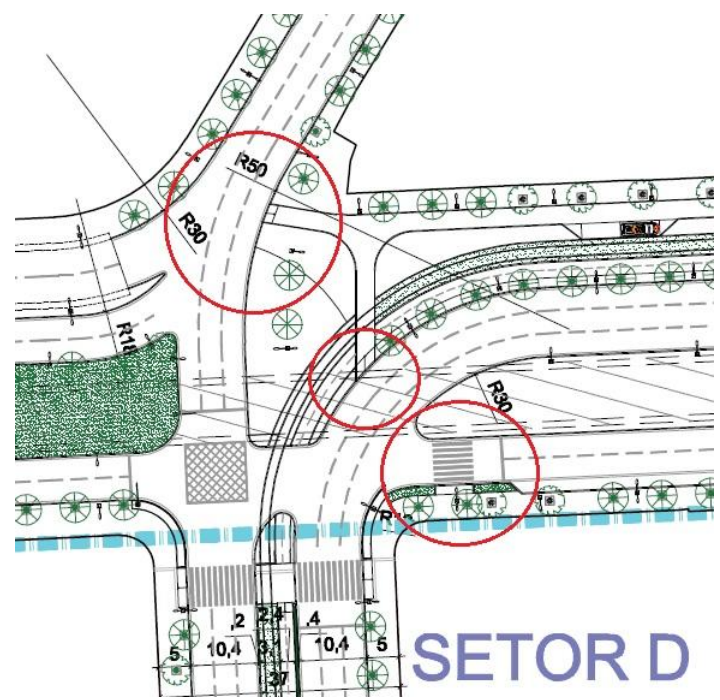

Figura 44 - Calçada estreita, impossibilitando a acessibilidade — setor D. Fonte: Projeto CDURP. 


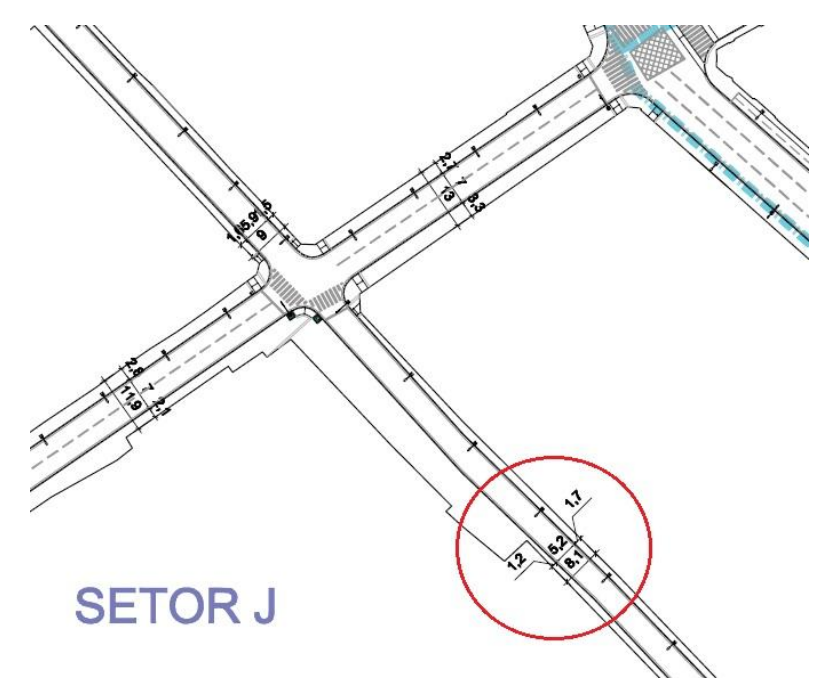

Figura 45 - Calçada estreita, impossibilitando a acessibilidade — setor $\mathrm{J}$. Fonte: Projeto CDURP.

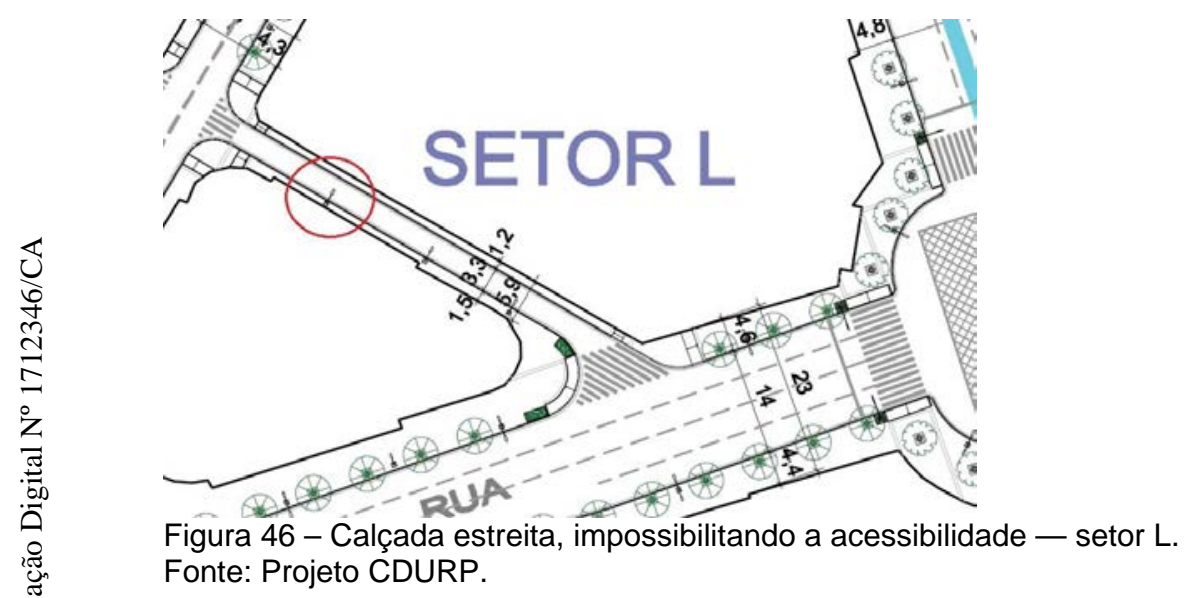

Foi considerado pela pesquisa que a acessibilidade interfere principalmente nas características de aprazibilidade — pois espaços inclusivos permitem melhor sensação de pertencimento; inclusão e equidade — pois a acessibilidade tem a capacidade de promover a inclusão de pessoas em todas as áreas da cidade; e diversidade - pois promove maior diversidade de usos e pessoas a usufruírem dos espaços.

\subsubsection{0.} Habitação

Conforme mencionado ao longo da fundamentação teórica, o projeto urbano mais sustentável deve contemplar diversidade de usos, incluindo a habitação popular. A falta de moradia é, atualmente, um dos maiores problemas das grandes metrópoles. 
A presença de residências em locais próximos ao Centro e dotados de infraestrutura pode impulsionar a sustentabilidade, pois diminui o gasto energético com transporte e promove a construção dos recursos urbanos necessários. A construção de moradias também pode promover maior sensação de pertencimento e segurança no local, além de estimular a diversidade de usos e de pessoas.

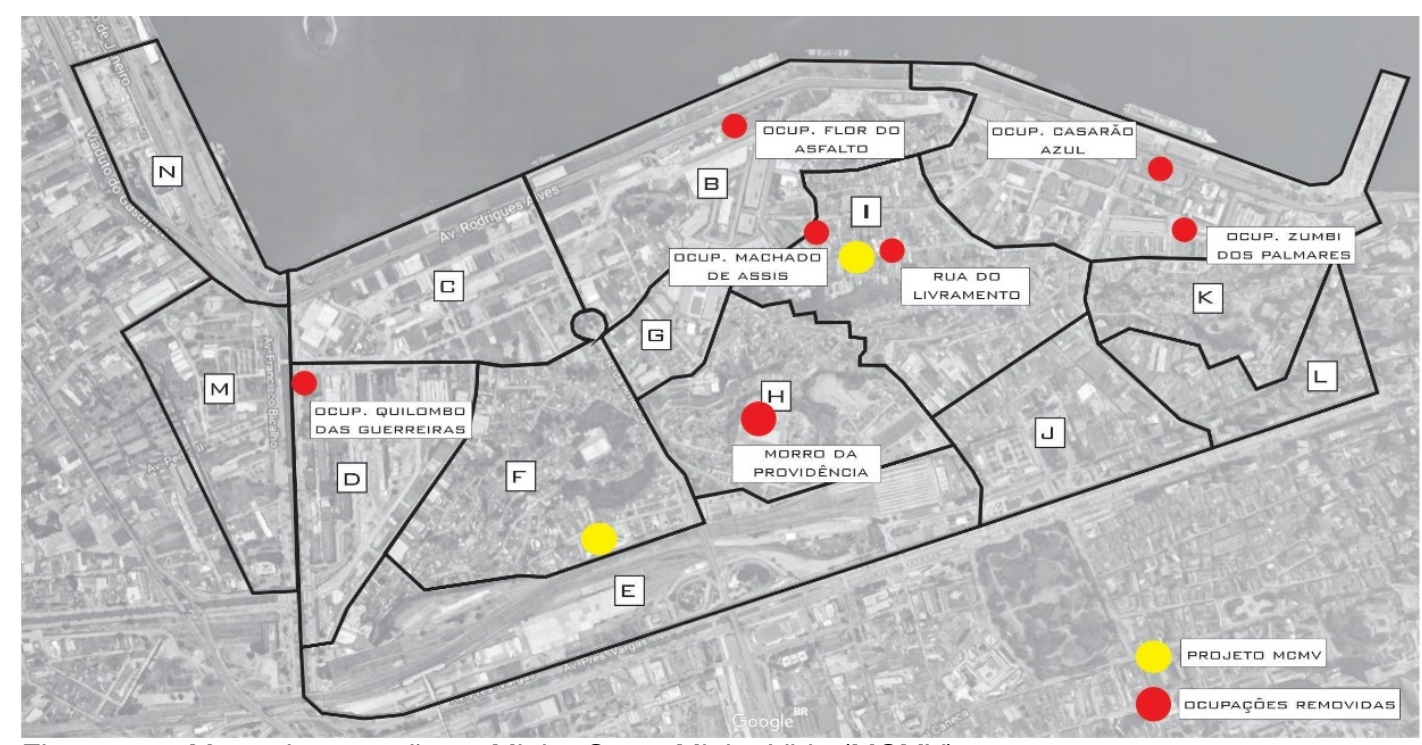

Figura 47 - Mapa de remoções e Minha Casa, Minha Vida (MCMV).

Fonte: Levantamento realizado pela autora com base nas informações obtidas segundo a Tabela 4.

Figura 48 - Sinal da Secretaria Municipal de Habitação (SMH) em residência que havia sido marcada para ser removida no Morro da Providência. 


\subsubsection{1.}

\section{Construção de novas moradias voltadas para a habitação popular}

Fonte: Mapa de ocupações e Minha Casa, Minha Vida (MCMV) (Figura 45).

De acordo com o presidente da CDURP, o projeto não contemplava, inicialmente, habitação popular, sendo hoje considerada sua aplicação em apenas duas áreas distintas: uma na Rua do Livramento - setor I — e outra próximo à Central do Brasil — setor F (Figura 45). Ambas são áreas degradadas e não suficientes para atender a toda a demanda da região.

O Instituto Brasileiro de Geografia e Estatística (IBGE) classifica como adequadas as habitações com as seguintes características:

[...] até dois moradores por dormitório; abastecimento de água por rede geral de distribuição; esgotamento sanitário por rede geral de esgoto ou pluvial, ou por fossa séptica; e lixo coletado, diretamente por serviço de limpeza ou em caçamba de serviço de limpeza. (apud BEZERRA, 2015).

Caso a moradia tenha de uma a três das características descritas, ela é considerada "semiadequada”, e caso não apresente nenhum desses requisitos, é qualificada de “inadequada” (apud BEZERRA, 2015). Segundo dados divulgados pela Câmara Brasileira da Indústria da Construção (CBIC), a cidade do Rio de Janeiro tinha, em 2015, um deficit de habitação em torno de 460.780 moradias.

A pesquisa Prata Preta, realizada pelo Observatório de Metrópoles (OM) em conjunto com a Central de Movimentos Populares (CMP), identificou ainda a existência de 54 cortiços na região do porto, onde vivem cerca de 1.120 pessoas. O levantamento identificou ao menos 29 edifícios com um a 10 cômodos, 17 com 11 a 25 cômodos, e seis com mais de 25 cômodos, entre eles um com 60 e outro com 70 quartos. Apesar de ser de conhecimento geral entre os habitantes da região, esse tipo de moradia não foi contemplado no Plano de Habitação de Interesse Social da Área Portuária. ${ }^{17}$

Durante a pesquisa de campo, foi possível verificar a presença de diversos ambulantes, principalmente na Praça Mauá, que têm residência em outros bairros e permanecem durante a semana em pensões ou habitações improvisadas por causa da distância.

17 Dados disponíveis em: <http://observatoriodasmetropoles.net.br/wp/projeto-prata-preta-mapainedito-dos-corticos-na-zona-portuaria-do-rio-2/> . Acesso em: 2 maio 2019. 
As informações obtidas com as entrevistas indicam que a população local tem interesse em permanecer na região. Entre o número total de moradores entrevistados, 91\% afirmaram que pretendem permanecer na região por mais de um ano, e 53\%, por mais de 10 anos, pelo menos.

Combater o processo de gentrificação que pode ocorrer com a instalação de megaprojetos é um grande desafio. Segundo o presidente da CDURP, não haveria gentrificação no local, já que, para ele, não existem pessoas morando ali (Anexo 3). Ainda segundo ele, a gentrificação é um processo natural, que acontece no mundo todo. Tal relato aponta descaso do poder público com a população, visto que se desconsidera sua existência.

A construção de moradias populares na região impacta diretamente a eficiência energética e a poluição do ar — pois diminui a necessidade de transporte para o Centro; a inclusão e equidade e diversidade — pois podem influenciar a diminuição da desigualdade e o aumento da diversidade de usos e de pessoas no local (Bezerra, 2015).

\subsubsection{2.}

\section{Manutenção da população local, não se realizando remoções compulsórias}

Fonte: Mapa de ocupações e Minha Casa, Minha Vida (MCMV) (Figura 45).

O crescente deficit habitacional, somado à grave desigualdade social presente na realidade da maior parte das metrópoles brasileiras, acaba levando muitas pessoas à situação de rua. $\mathrm{Na}$ ausência de moradias, a população muitas vezes acaba encontrando como alternativa ocupar os edifícios sem uso na cidade. O documentário Atrás da porta retratou a forma truculenta como foram feitas as remoções na região, principalmente na ocupação Casarão Azul (Figura 47), que tinha 120 crianças entre as famílias que residiam no local. A maioria das remoções foi realizada de forma compulsória, e nada foi construído no local, como foi o caso da ocupação da Rodrigues Alves, principal polo turístico da região.

A maior parte da população removida não teve a opção de permanecer em local próximo. Conforme destacado por Ximenes (2017), a ocupação Machado de Assis, por exemplo, teve um valor máximo de 20 mil; no entanto, o custo por metro quadrado de área na Saúde está em 5 mil, e na Gamboa, em 7 mil. Uma família, portanto, com esse valor conseguiria uma casa de $4 \mathrm{~m}^{2}$. O valor do aluguel social 
oferecido para as famílias era de 400 reais, ainda de acordo com o relatório muito abaixo do valor da região. Segundo o mesmo relatório, para os moradores das ocupações Livramento e Machado de Assis foram oferecidas casas do Minha Casa, Minha Vida (MCMV) na Senador Camará, 45 km de distância da região. Transferir a população residente do local para áreas mais distantes, muitas vezes ainda sem estrutura, pode impactar a sustentabilidade, pois gera também maior demanda de locomoção, por exemplo.

Não remover de forma compulsória as famílias residentes impacta diretamente a eficiência energética e a poluição, tendo em vista os motivos relatados anteriormente, bem como a inclusão e equidade - pois podem influenciar a diminuição da desigualdade e o aumento da diversidade de usos e de pessoas no local.

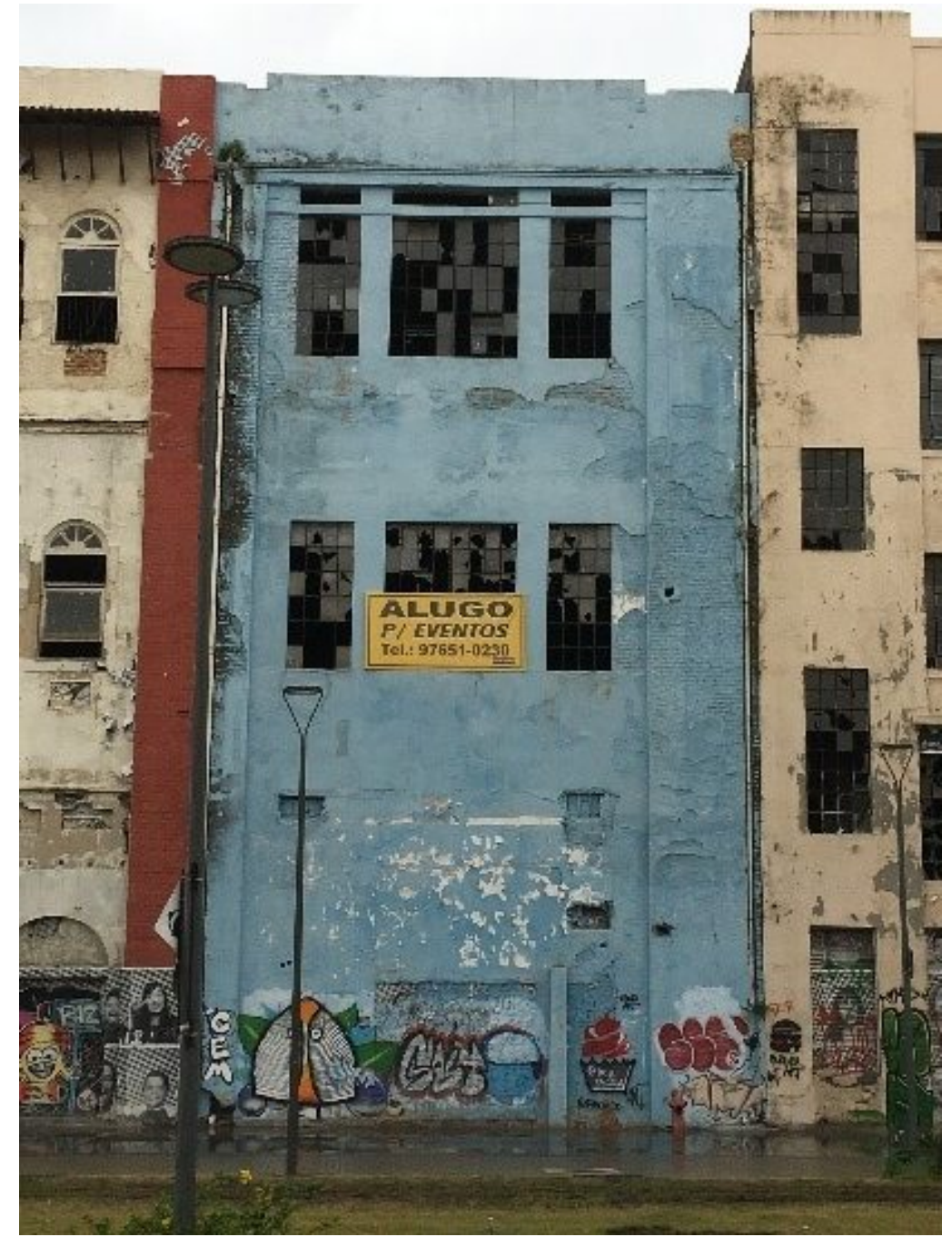

Figura 49 - Edifício da fachada antiga da ocupação Casarão Azul. Fonte: <https://www.caurj.gov.br/pesquisadoras-da-uff-falam-sobre-as-remocoes-da-zonaportuaria-do-rio/>. Acesso em: 2 maio 2019. 


\begin{tabular}{|c|c|c|c|c|c|c|}
\hline $\begin{array}{c}\text { Comunidadel } \\
\text { ocupação }\end{array}$ & Endereço & $\begin{array}{l}\text { Propriedade do } \\
\text { terreno }\end{array}$ & $\begin{array}{l}\text { Tempo de } \\
\text { ocupação }\end{array}$ & $\begin{array}{c}\text { Número } \\
\text { de } \\
\text { famílias } \\
\text { removidas }\end{array}$ & $\begin{array}{l}\text { Número de } \\
\text { famílias } \\
\text { ameaçadas }\end{array}$ & $\begin{array}{c}\text { Total } \\
\text { de } \\
\text { famílias }\end{array}$ \\
\hline $\begin{array}{l}\text { Ocupação } \\
\text { Machado de } \\
\text { Assis }\end{array}$ & $\begin{array}{l}\text { Rua da } \\
\text { Gamboa, } \\
111\end{array}$ & $\begin{array}{c}\text { Antiga } \\
\text { propriedade da } \\
\text { empresa } \\
\text { Unilever, } \\
\text { desapropriada } \\
\text { em nome da } \\
\text { Prefeitura em } \\
2006 \\
\end{array}$ & 2008 & 150 & Removida & 150 \\
\hline $\begin{array}{l}\text { Ocupação } \\
\text { Flor do } \\
\text { Asfalto } \\
\end{array}$ & $\begin{array}{c}\text { Rua } \\
\text { Rodrigues } \\
\text { Alves } \\
\end{array}$ & SNPU & 2006 & 30 & Removida & 30 \\
\hline $\begin{array}{c}\text { Ocupação na } \\
\text { Rua do } \\
\text { Livramento }\end{array}$ & $\begin{array}{c}\text { Rua do } \\
\text { Livramento }\end{array}$ & Não identificada & $\begin{array}{c}\text { Sem } \\
\text { informação }\end{array}$ & - & 400 & 400 \\
\hline $\begin{array}{l}\text { Ocupação } \\
\text { Boa Vista }\end{array}$ & $\begin{array}{c}\text { Não } \\
\text { identificado } \\
\end{array}$ & Não identificada & 1998 & 35 & Removida & 35 \\
\hline $\begin{array}{l}\text { Quilombo das } \\
\text { Guerreiras }\end{array}$ & $\begin{array}{c}\text { Avenida } \\
\text { Francisco } \\
\text { Bicalho, } 49\end{array}$ & $\begin{array}{c}\text { Companhia } \\
\text { Docas do Rio de } \\
\text { Janeiro }\end{array}$ & 2006 & - & 50 & 50 \\
\hline $\begin{array}{l}\text { Zumbi dos } \\
\text { Palmares }\end{array}$ & $\begin{array}{c}\text { Avenida } \\
\text { Venezuela, } \\
53 \\
\end{array}$ & $\begin{array}{c}\text { Instituto } \\
\text { Nacional do } \\
\text { Seguro Social }\end{array}$ & $\begin{array}{c}\text { Sem } \\
\text { informação }\end{array}$ & 133 & Removida & 133 \\
\hline $\begin{array}{l}\text { Ocupação } \\
\text { Carlos } \\
\text { Marighela } \\
\end{array}$ & $\begin{array}{c}\text { Rua } \\
\text { Riachuelo, } \\
48 \\
\end{array}$ & $\begin{array}{c}\text { Instituto } \\
\text { Nacional do } \\
\text { Seguro Social }\end{array}$ & $\begin{array}{c}\text { Sem } \\
\text { informação }\end{array}$ & 47 & Removida & 47 \\
\hline $\begin{array}{c}\text { Ocupação } \\
\text { Casarão Azul }\end{array}$ & $\begin{array}{c}\text { Rua } \\
\text { Rodrigues } \\
\text { Alves, } 143 \\
\end{array}$ & Não identificada & $\begin{array}{c}\text { Sem } \\
\text { informação }\end{array}$ & 70 & Removida & 70 \\
\hline $\begin{array}{c}\text { Morro da } \\
\text { Providência }\end{array}$ & $\begin{array}{c}\text { Morro da } \\
\text { Providência }\end{array}$ & Não identificada & \begin{tabular}{c|} 
Sem \\
informação
\end{tabular} & 140 & 692 & 832 \\
\hline
\end{tabular}

Tabela 4 - Tabela de ocupações.

Fonte: Elaboração própria a partir de informações obtidas em Ximenes (2017).

\subsubsection{1. \\ Participação}

\subsubsection{1.}

Participação da população envolvida em sua concepção

Fonte: Entrevistas.

Algumas ações propostas pelas obras tiveram resistência por parte dos moradores, como a construção do teleférico da Providência. Conforme mencionado anteriormente ao longo do trabalho, a obra proposta tomou o lugar da principal área de lazer local — a quadra esportiva — e ainda provocou a remoção diversas famílias da região. Se o desenvolvimento sustentável está associado a dar recursos para as pessoas atenderem às suas próprias necessidades, o projeto urbano deve contemplar o processo participativo para compreender quais são essas demandas. A imposição de um modelo de desenvolvimento pode muitas vezes gerar ainda mais 
desigualdades sociais. A sustentabilidade, portanto, depende da participação popular tendo como objetivo um processo equitativo e inclusivo.

De acordo com as entrevistas realizadas, $72 \%$ dos moradores entrevistados afirmaram que não conheciam o projeto antes de sua implantação. Um dos moradores tidos como mais antigos do Morro da Conceição, afirmou que sequer tinha conhecimento da demolição da Perimetral antes das explosões, e que estas geraram um grande transtorno. Segundo ele, os moradores acordaram assustados de madrugada com as explosões próximas às suas casas.

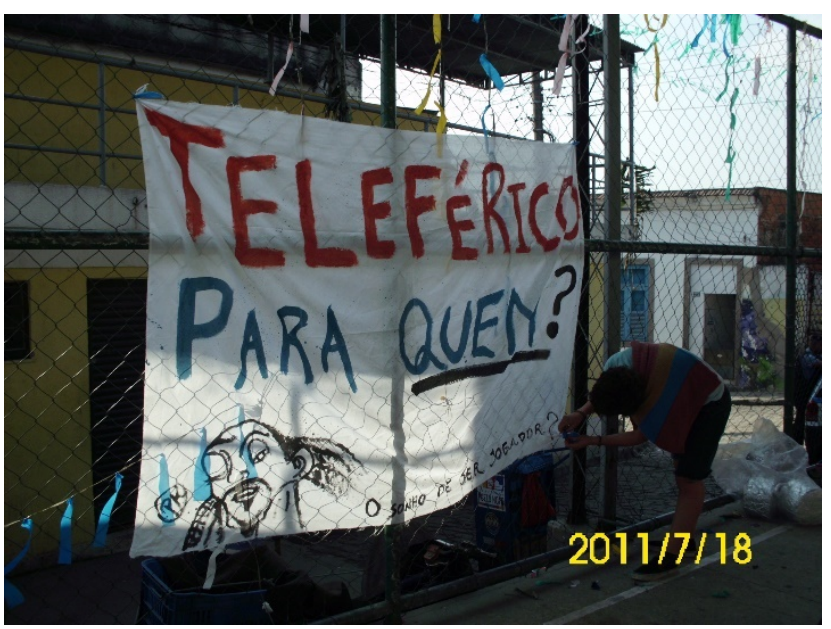

Figura 50 - Protestos contra a construção do teleférico no Morro da Providência.

Fonte: Carta aberta. Fórum Comunitário do Porto. Disponível em: $<$ https://forumcomunitariodoporto.wordpress.com/2012/09/12/carta-aberta-a-populacao-do-rio-dejaneiro/>. Acesso em: 24 abr. 2019.

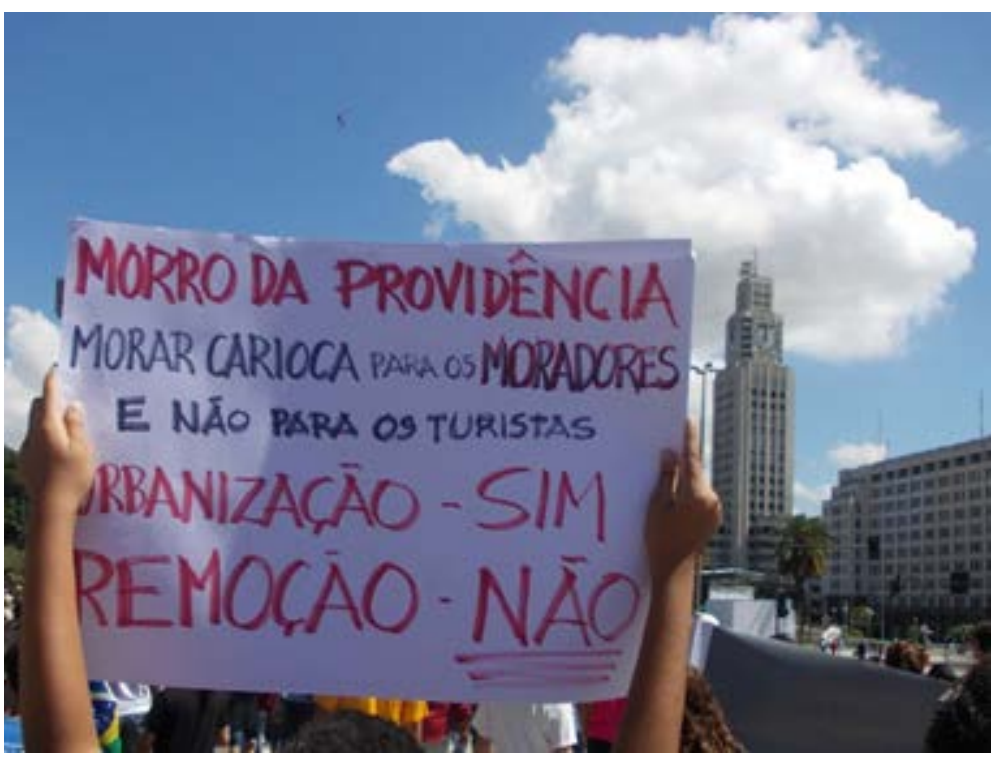

Figura 51 - Protestos dos moradores da Providência.

Fonte: <http://rioonwatch.org.br/?p=7444>. Acesso em: 25 abr. 2019. 
Durante a entrevista, o representante da CDURP não soube responder sobre a realização de audiências públicas na época da implementação do projeto, visto que não trabalhava no local no período. Nenhum outro funcionário que estava no local soube responder à pergunta ou encontrou documento que contivesse a informação solicitada.

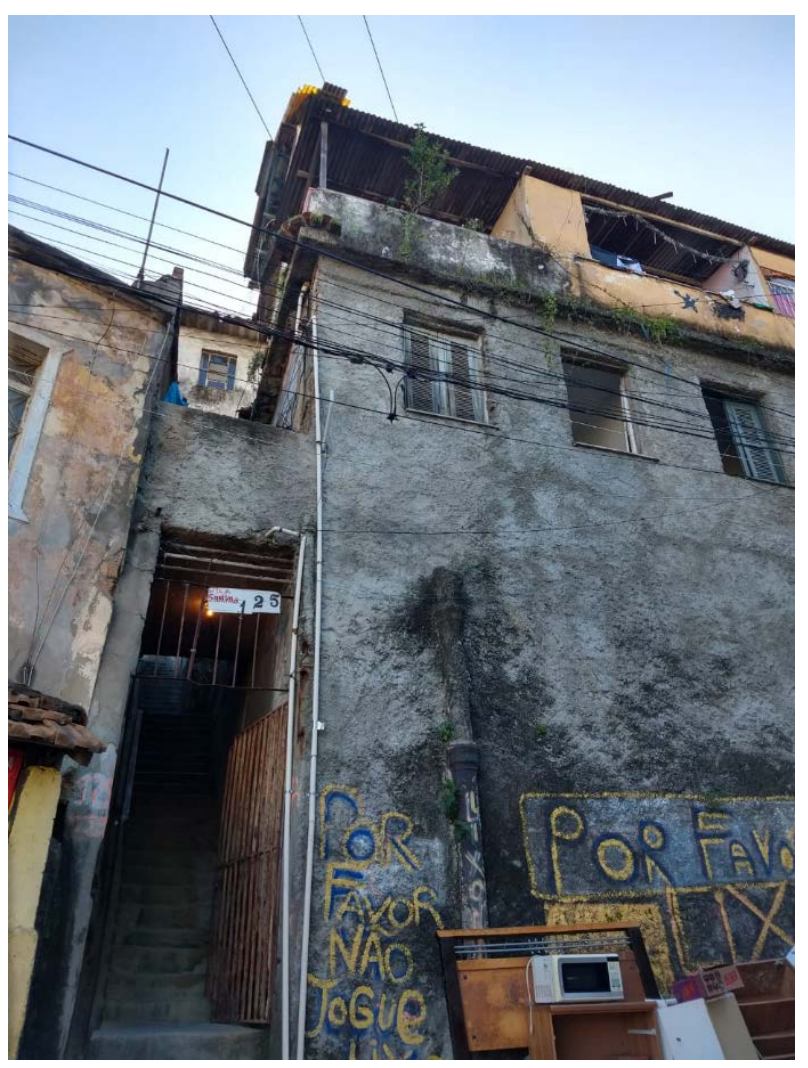

Figura 52 - Local de onde foram removidas 20 casas para a construção do teleférico.

\subsubsection{2.}

\section{Equipamentos urbanos}

\subsubsection{1.}

Atendimento da área por escolas, creches e hospitais Fonte: Mapa de diversidade de usos e equipamentos (Figura 21).

Conforme a fundamentação teórica desenvolvida ao longo da pesquisa, o desenvolvimento sustentável deve incluir uma distribuição equitativa de recursos urbanos. A presença de hospitais, escolas e creches, bem como de áreas de lazer, praças e espaços destinados à prática de esportes, pode garantir uma melhor inclusão e desenvolvimento social da área. 
A disposição desses equipamentos como critério de análise também auxilia na redução da necessidade de viagens, o que permite uma diminuição da emissão de gases, influenciando a eficiência energética e a poluição do ar. O critério também permite uma melhoria na inclusão e equidade — pois distribui melhor os equipamentos públicos necessários para o desenvolvimento social e a diversidade —, permitindo maior variedade de usos e de perfis populacionais.

\subsubsection{3.}

\section{Diversidade}

A perda da diversidade é um dos motivos que podem comprometer a vitalidade e a sustentabilidade dos centros urbanos. Jane Jacobs, em seu consagrado livro Morte e vida das grandes cidades, identificou que algumas áreas que perderam suas características essenciais acabaram tornando-se menos interessantes e, posteriormente, mais vazias. A pesquisa apresentada pela autora demonstrou também, com diversos exemplos, que muitas vezes a razão da perda da diversidade está atrelada a seu sucesso. A análise dos estudos de caso apresentados pela obra apontam que a valorização comercial tende a criar espaços hegemônicos, nos quais as áreas que se sobrepõem às demais são aquelas que têm maior possibilidade de retorno financeiro. Os critérios analisados têm como objetivo criar espaços mais diversos, capazes de promover sua vitalidade e o desenvolvimento sustentável.

\subsubsection{1.}

Existência de diferentes padrões habitacionais, equipamentos e usos Fonte: Mapa de diversidade de usos e equipamentos (Figura 21).

A presença de diferentes usos e padrões habitacionais, como habitações populares, pode impactar a diversidade e a inclusão da área. Segundo Jacobs (2011), áreas com mais diversidade têm maiores chances de sobreviver a possíveis períodos de crise do que áreas homogêneas. Ainda de acordo a autora, em seu livro Morte e vida das grandes cidades, muitas vezes o motivo da morte de uma área é justamente seu sucesso.

Conforme demonstrado pela autora, um dos possíveis processos que podem ocorrer e prejudicar, ou até mesmo impossibilitar, o desenvolvimento da região é o fato de que algumas áreas acabam valorizando-se por causa de suas características 
essenciais, e com o processo de valorização os espaços acabam sendo ocupados por quem tem mais recurso, em razão dos preços mais altos. Assim, as atividades e os moradores mais tradicionais acabam mudando-se para outros bairros, e a área perde sua vitalidade e a característica que a tornava atrativa, esvaziando-se.

A região apresenta, atualmente, prédios inteiros vazios com anúncios de aluguel e venda. Dona Irene, proprietária do bar Bodega do Sal - que promove tradicionais rodas de samba e outras atividades na Pedra do Sal —, afirmou durante a entrevista realizada que também pretendia mudar-se em breve para outro local. Segundo ela, além de o preço do aluguel inviabilizar sua permanência, o aumento no fluxo de pessoas ao local trouxe diversos transtornos para os moradores, como barulho até tarde e diminuição da segurança.

\section{4. \\ Resultados}

Os resultados finais da pesquisa serão descritos pelos dados da tabela geral que serviu de base para a elaboração das tabelas individuais apresentadas e que servirão de mapa para cada categoria. A metodologia de análise de cada critério foi descrita ao longo do presente trabalho e poderá ser verificada no Capítulo 3.

\subsection{1. \\ Eficiência energética}

\section{Relação forte (+3 pontos)}

- Definição, no projeto, de parâmetros construtivos de afastamento e gabarito que permitam a entrada de luz natural em todas as unidades de residência e trabalho

o Atingiram esse critério as áreas A, B, C, D, E, F, I, M

- Atendimento da área por ciclovias e calçadas que favoreçam o transporte não motor

o Atingiram esse critério as áreas: A, B, C, D

- Redução das vias geradoras de trânsito e ruídos no entorno

o Atingiram esse critério as áreas: A, B, F, H, I, K

- Adequação do projeto urbano para atendimento do aumento de densidade previsto pela venda de Cepacs 
o Atingiram esse critério as áreas: A, B, C, D, E, M

- Atendimento da área por usos e equipamentos diversos

o Atingiu esse critério a área: $\mathrm{K}$

- Plantio de novas árvores e áreas verdes

o Atingiram esse critério as áreas: A, B, C, D, J, L, M, N

\section{Relação média (+2 pontos)}

- Instalação de iluminação artificial nas áreas públicas

o Atingiram esse critério as áreas: A, B, C, D, K, M, N

- Atendimento da área por escola, creches e hospitais

o Atingiram esse critério as áreas: A, B, C, G, K

- Atendimento da área por sistemas de transporte de massa

o Atingiram esse critério as áreas: E, J

\section{Relação baixa ( +1 ponto)}

- Atendimento da área por pontos de ônibus e VLT

o Atingiram esse critério as áreas: A, B, C, D, E, G, J, L

- Construção de novas moradias voltadas para habitação

o Atingiram esse critério as áreas: F, I

\begin{tabular}{|l|c|c|c|c|c|c|c|c|c|c|c|c|c|c|c|}
\hline \multicolumn{10}{|c|}{ Eficiência energética } \\
\hline \multicolumn{110}{|c|}{ Critério } & & 26 & A & B & C & D & E & F & G & H & I & J & K & L & M & N \\
\hline $\begin{array}{l}\text { Definição, no projeto, } \\
\text { de parâmetros } \\
\text { construtivos de } \\
\text { afastamento e gabarito } \\
\text { que permitam a } \\
\text { entrada de luz natural } \\
\text { em todas as unidades } \\
\text { de residência e } \\
\text { trabalho }\end{array}$ & 3 & 3 & 3 & 3 & 3 & 3 & 3 & 0 & 0 & 3 & 0 & 0 & 0 & 3 & 0 \\
\hline $\begin{array}{l}\text { Instalação de } \\
\text { iluminação artificial nas } \\
\text { áreas públicas }\end{array}$ & 2 & 2 & 2 & 2 & 2 & 0 & 0 & 0 & 0 & 0 & 0 & 2 & 0 & 2 & 2 \\
\hline $\begin{array}{l}\text { Atendimento da área } \\
\text { por pontos de ônibus e } \\
\text { veículo VLT }\end{array}$ & 1 & 1 & 1 & 1 & 1 & 1 & 0 & 1 & 0 & 0 & 1 & 0 & 1 & 0 & 0 \\
\hline $\begin{array}{l}\text { Atendimento da área } \\
\text { por sistemas de } \\
\text { transporte de massa }\end{array}$ & 2 & 0 & 0 & 0 & 0 & 2 & 0 & 0 & 0 & 0 & 2 & 0 & 0 & 0 & 0 \\
\hline
\end{tabular}




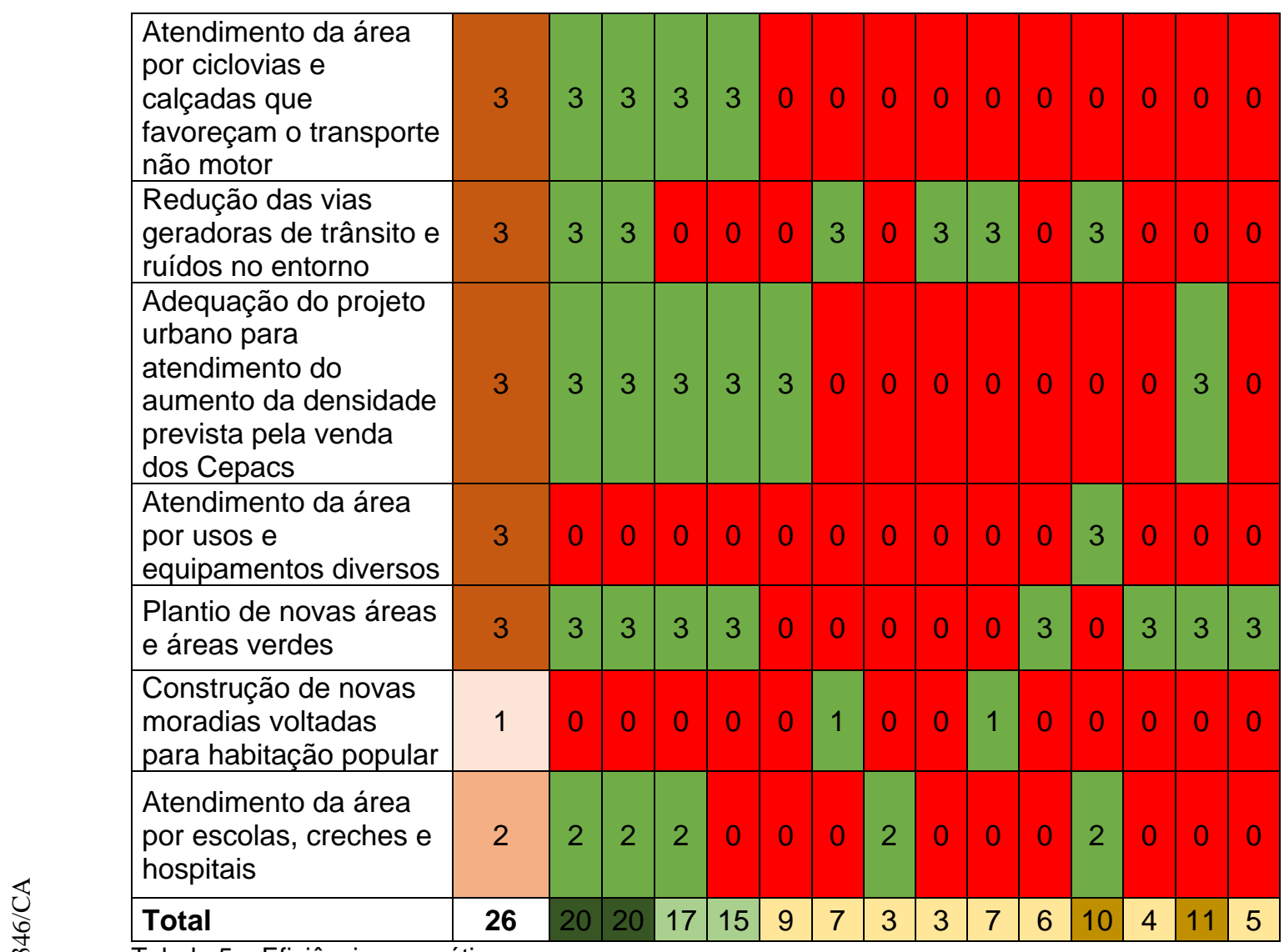

Tabela 5 - Eficiência energética.

\section{EFICIÊNCIA ENERGÉTICA}

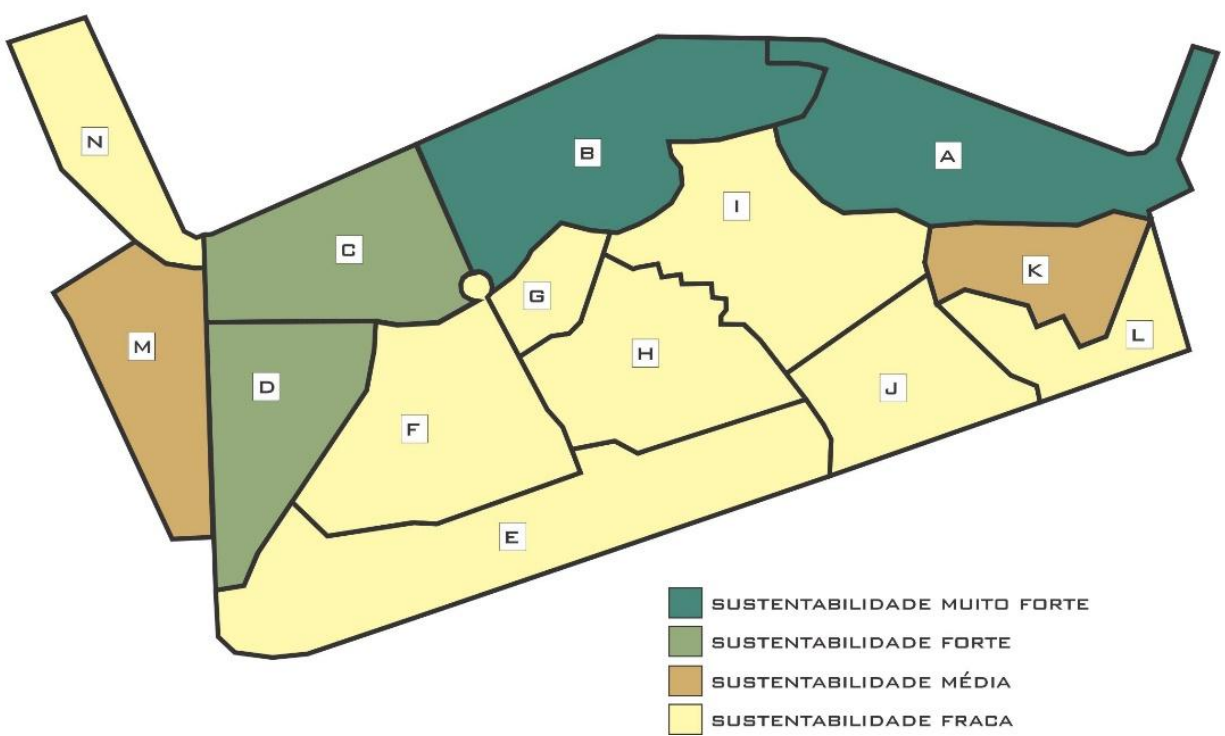

Figura 53 - Mapa de eficiência energética.

De acordo com a Tabela 5, as áreas A e B (Praça Mauá e Boulevard) foram as que mais receberam contribuições para a eficiência energética. Os critérios que 
mais contribuíram para esse resultado foram a construção do VLT e de caminhos voltados para os pedestres (Figura 17). Nas regiões descritas, também foram realizadas obras com instalação de postes de iluminação com fibra óptica e definidos padrões construtivos, que garantem a iluminação e a ventilação em todos os cômodos (Figura 15), o que pode influenciar a diminuição da necessidade de uso de aparelhos de ar condicionado nas edificações. As áreas A e B também não têm vias geradoras de trânsito, que podem promover maior congestionamento e consumo de combustíveis fósseis (Figura 17).

Em contrapartida, as áreas G (Parque Olímpico), H (Providência), L (Senador Pompeu) e N (Caju) tiveram uma contribuição baixa para sustentabilidade na categoria analisada. Pode-se observar também que essas são áreas atualmente mais áridas, com menor presença de árvores (Figura 22). Com exceção da área G, que contém um ponto de VLT próximo e o Parque Olímpico - que foi um grande investimento das obras realizadas —, as áreas com baixa contribuição para eficiência energética, em geral, são aquelas com menor investimento em recursos urbanos e também possível menor retorno econômico pela venda dos Cepacs.

\subsection{2.}

\section{Poluição do ar}

\section{Critérios relacionados}

\section{Relação forte (+3 pontos)}

- Definição, no projeto, de parâmetros construtivos de afastamento e gabarito que permitam a entrada de luz natural em todas as unidades de residência e trabalho

o Atingiram esse critério as áreas: A, B, C, D, E, F, I, M

- Atendimento da área por ciclovias e calçadas que favoreçam o transporte não motor

o Atingiram esse critério as áreas: A, B, C, D

- Redução das vias geradoras de trânsito e ruídos no entorno

o Atingiram esse critério as áreas: A, B, F, H, I, K

- Adequação do projeto urbano para atendimento do aumento de densidade previsto pela venda de Cepacs

o Atingiram esse critério as áreas: A, B, C, D, E, M 
- Atendimento da área por usos e equipamentos diversos

o Atingiu esse critério a área: K

- Plantio de novas árvores e áreas verdes

o Atingiram esse critério as áreas: A, B, C, D, J, L, M, N

- Atendimento da área por escola, creches e hospitais

o Atingiram esse critério as áreas: A, B, C, G, K

\section{Relação média (+2 pontos)}

- Atendimento da área por sistemas de transporte de massa

o Atingiram esse critério as áreas: E, J

\section{Relação baixa (+1 ponto)}

- Atendimento da área por pontos de ônibus e VLT

o Atingiram esse critério as áreas: A, B, C, D, E, G, J, L

- Construção de novas moradias voltadas para habitação

o Atingiram esse critério as áreas: F, I

\begin{tabular}{|l|c|c|c|c|c|c|c|c|c|c|c|c|c|c|c|}
\hline \multicolumn{10}{|c|}{ Coluição do ar } \\
\hline \multicolumn{1}{|c|}{ Critério } & 25 & A & B & C & D & E & F & G & H & I & J & K & L & M & N \\
\hline $\begin{array}{l}\text { Definição, no projeto, } \\
\text { de parâmetros } \\
\text { construtivos de } \\
\text { afastamento e gabarito } \\
\text { que permitam a } \\
\text { entrada de luz natural } \\
\text { em todas as unidades } \\
\text { de residência e } \\
\text { trabalho }\end{array}$ & 3 & 3 & 3 & 3 & 3 & 3 & 3 & 0 & 0 & 3 & 0 & 0 & 0 & 3 & 0 \\
\hline $\begin{array}{l}\text { Atendimento da área } \\
\text { por pontos de ônibus e } \\
\text { VLT }\end{array}$ & 1 & 1 & 1 & 1 & 1 & 1 & 0 & 1 & 0 & 0 & 1 & 0 & 1 & 0 & 0 \\
\hline $\begin{array}{l}\text { Atendimento da área } \\
\text { por sistemas de } \\
\text { transporte de massa }\end{array}$ & 2 & 0 & 0 & 0 & 0 & 2 & 0 & 0 & 0 & 0 & 2 & 0 & 0 & 0 & 0 \\
\hline $\begin{array}{l}\text { Atendimento da área } \\
\text { por ciclovias e } \\
\text { calçadas que } \\
\text { favoreçam o transporte } \\
\text { não motor }\end{array}$ & 3 & 3 & 3 & 3 & 3 & 0 & 0 & 0 & 0 & 0 & 0 & 0 & 0 & 0 & 0 \\
\hline $\begin{array}{l}\text { Redução das vias } \\
\text { geradoras de trânsito e } \\
\text { ruídos no entorno }\end{array}$ & 3 & 3 & 3 & 0 & 0 & 0 & 3 & 0 & 3 & 3 & 0 & 3 & 0 & 0 & 0 \\
\hline $\begin{array}{l}\text { Adequação do projeto } \\
\text { urbano para }\end{array}$ & 3 & 3 & 3 & 3 & 3 & 3 & 0 & 0 & 0 & 0 & 0 & 0 & 0 & 3 & 0 \\
\hline
\end{tabular}




\begin{tabular}{|l|l|l|l|l|l|l|l|l|l|l|l|l|l|l|l|}
\hline $\begin{array}{l}\text { atendimento do } \\
\begin{array}{l}\text { aumento da densidade } \\
\text { prevista pela venda } \\
\text { dos Cepacs }\end{array}\end{array}$ & & & & & & & & & & & & & & & \\
\hline $\begin{array}{l}\text { Atendimento da área } \\
\text { por usos e } \\
\text { equipamentos diversos }\end{array}$ & 3 & 0 & 0 & 0 & 0 & 0 & 0 & 0 & 0 & 0 & 0 & 3 & 0 & 0 & 0 \\
\hline $\begin{array}{l}\text { Plantio de novas áreas } \\
\text { e áreas verdes }\end{array}$ & 3 & 3 & 3 & 3 & 3 & 0 & 0 & 0 & 0 & 0 & 3 & 0 & 3 & 3 & 3 \\
\hline $\begin{array}{l}\text { Construção de novas } \\
\text { moradias voltadas para } \\
\text { habitação popular }\end{array}$ & 1 & 0 & 0 & 0 & 0 & 0 & 1 & 0 & 0 & 1 & 0 & 0 & 0 & 0 & 0 \\
\hline $\begin{array}{l}\text { Atendimento da área } \\
\text { por escolas, creches e } \\
\text { hospitais }\end{array}$ & 3 & 3 & 3 & 3 & 0 & 0 & 0 & 3 & 0 & 0 & 0 & 3 & 0 & 0 & 0 \\
\hline \begin{tabular}{l} 
Total \\
\hline
\end{tabular} & 25 & 19 & 19 & 16 & 13 & 9 & 7 & 4 & 3 & 7 & 6 & 9 & 4 & 9 & 3 \\
\hline
\end{tabular}

Tabela 6 - Poluição do ar.

\section{PロLUIÇÃ̄ DQ AR}

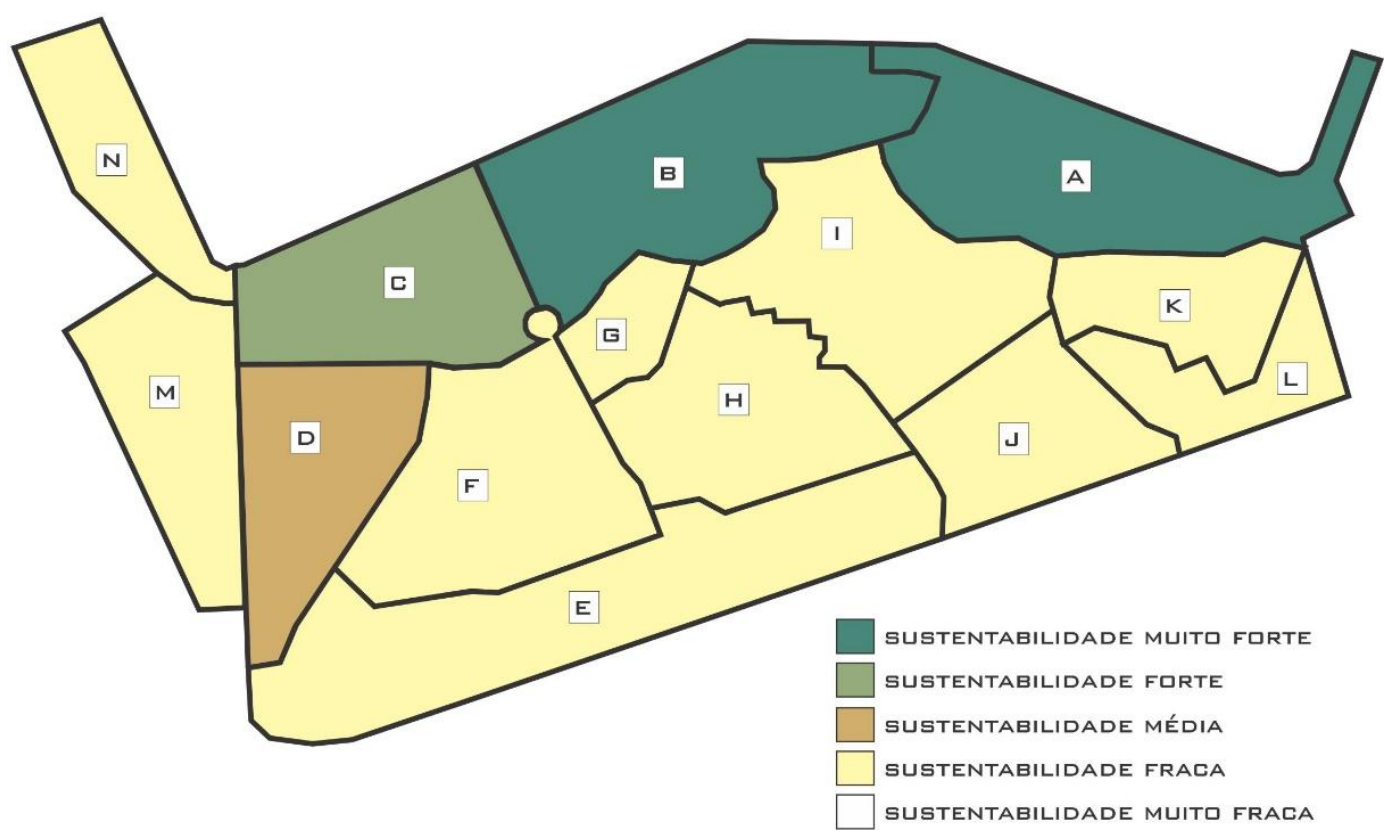

Figura 54 - Mapa de poluição do ar.

De acordo com a Tabela 6, as áreas A e B (Praça Mauá e Boulevard) foram as que mais receberam contribuições para a diminuição da poluição do ar. Os critérios que mais contribuíram para esse resultado foram a construção do VLT e de caminhos voltados para os pedestres (Figura 17). Nas regiões descritas, também foram realizadas obras com instalação de postes de iluminação com fibra óptica e definidos padrões construtivos, que garantem a iluminação e a ventilação em todos os cômodos (Figura 15), o que pode influenciar a diminuição da necessidade de uso de aparelhos de ar condicionado nas edificações. As áreas A e B também não têm 
vias geradoras de trânsito, que podem promover maior congestionamento e consumo de combustíveis fósseis (Figura 17).

Em contrapartida, as áreas G (Parque Olímpico), H (Providência), L (Senador Pompeu) e N (Caju) tiveram uma contribuição baixa para sustentabilidade na categoria analisada (Figura 54). Pode-se observar também que essas são áreas atualmente mais áridas, com menor presença de árvores. Com exceção da área G, que contém um ponto de VLT próximo e o Parque Olímpico (Figura 35) - que foi um grande investimento das obras realizadas —, as áreas com baixa contribuição para diminuição da poluição do ar, em geral, são aquelas com menor investimento em recursos urbanos e também possível menor retorno econômico pela venda dos Cepacs.

\subsection{3. \\ Recursos hídricos}

\section{Relação forte (+3 pontos)}

- Plantio de novas árvores e áreas verdes

o Atingiram esse critério as áreas: A, B, C, D, J, L, M, N

- Instalação de rede de água

o Atingiram esse critério as áreas: A, B, C, D, M, N

- Instalação de rede de esgoto e drenagem

o Atingiram esse critério as áreas: A, B, C, D, M, N

- Aplicação de medidas para evitar alagamentos pelas chuvas ou elevação do nível no mar em regiões urbanizadas

o Atingiram esse critério as áreas: F, H, I, J, K, L

\begin{tabular}{|l|c|c|c|c|c|c|c|c|c|c|c|c|c|c|c|}
\hline \multicolumn{10}{|c|}{ Aecursos hídricos } \\
\hline \multicolumn{10}{|c|}{ Critério } & & \multicolumn{10}{|c|}{ A } & B & C & D & E & F & G & H & I & J & K & L & M & N \\
\hline $\begin{array}{l}\text { Plantio de novas áreas } \\
\text { e áreas verdes }\end{array}$ & 3 & 3 & 3 & 3 & 3 & 0 & 0 & 0 & 0 & 0 & 3 & 0 & 3 & 3 & 3 \\
\hline $\begin{array}{l}\text { Instalação de rede de } \\
\text { água }\end{array}$ & 3 & 3 & 3 & 3 & 3 & 0 & 0 & 0 & 0 & 0 & 0 & 0 & 0 & 3 & 3 \\
\hline $\begin{array}{l}\text { Instalação de rede de } \\
\text { esgoto e drenagem }\end{array}$ & 3 & 3 & 3 & 3 & 3 & 0 & 0 & 0 & 0 & 0 & 0 & 0 & 0 & 3 & 3 \\
\hline $\begin{array}{l}\text { Aplicação de medidas } \\
\text { para evitar } \\
\text { alagamentos pelas } \\
\text { chuvas ou elevação do }\end{array}$ & 3 & 0 & 0 & 0 & 0 & 0 & 3 & 0 & 3 & 3 & 3 & 3 & 3 & 0 & 0 \\
\hline
\end{tabular}




\begin{tabular}{|l|l|l|l|l|l|l|l|l|l|l|l|l|l|l|l|}
\hline $\begin{array}{l}\text { nível do mar em } \\
\text { regiões urbanizadas }\end{array}$ & & & & & & & & & & & & & & & \\
\hline Total & 12 & 9 & 9 & 9 & 9 & 0 & 3 & 0 & 3 & 3 & 6 & 3 & 6 & 9 & 9 \\
\hline
\end{tabular}

Tabela 7 - Recursos hídricos.

RECURSOS HÍDRICIS

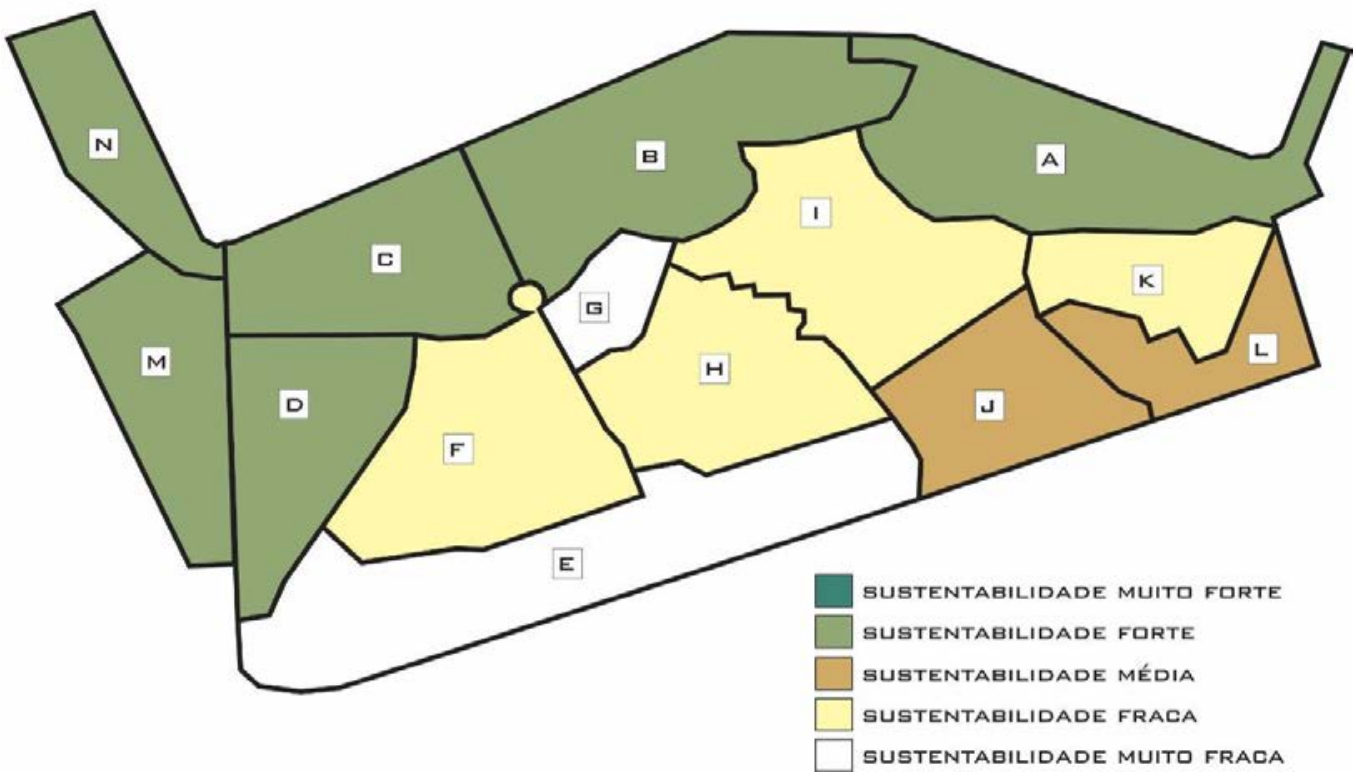

Figura 55 - Mapa de recursos hídricos.

As áreas que tiveram a maior contribuição na categoria recursos hídricos foram: A, B, C, D, M, N. Foi possível verificar que as áreas que se destacaram positivamente são também as que têm mais investimento em infraestrutura na região e que têm um potencial retorno pela venda dos Cepacs. Em contrapartida, as áreas E e G não conseguiram atender a nenhum dos critérios relacionados com a categoria descrita.

\subsection{4.}

\section{Resíduos sólidos}

\section{Critérios relacionados}

\section{Relação forte ( +3 pontos)}

- Redução do acúmulo de lixo nas calçadas

o Atingiram esse critério as áreas: A, B, C, D, F, G, J, K, L, M, N

- Instalação de lixeiras no mobiliário e lixeiras para coleta seletiva

o Atingiram esse critério as áreas: A, B, C, D, F, G, J, K, L, M, N 


\begin{tabular}{|l|c|c|c|c|c|c|c|c|c|c|c|c|c|c|c|}
\hline \multicolumn{11}{|c|}{ Resíduos sólidos } \\
\hline \multicolumn{110}{|c|}{ Critério } & & \multicolumn{110}{|c|}{ Áreas do porto } \\
\hline & 6 & A & B & C & D & E & F & G & H & I & J & K & L & M & N \\
\hline $\begin{array}{l}\text { Redução do acúmulo } \\
\text { de lixo nas calçadas }\end{array}$ & 3 & 3 & 3 & 3 & 3 & 0 & 3 & 3 & 0 & 0 & 3 & 3 & 3 & 3 & 3 \\
\hline $\begin{array}{l}\text { Instalação de lixeiras no } \\
\text { mobiliário e lixeiras } \\
\text { para coleta seletiva }\end{array}$ & 3 & 3 & 3 & 3 & 3 & 0 & 3 & 3 & 0 & 0 & 3 & 3 & 3 & 3 & 3 \\
\hline Total & 6 & 6 & 6 & 6 & 6 & 0 & 6 & 6 & 0 & 0 & 6 & 6 & 6 & 6 & 6 \\
\hline
\end{tabular}

Tabela 8 - Resíduos sólidos.

\section{REsídUas SQ́LIDAs}

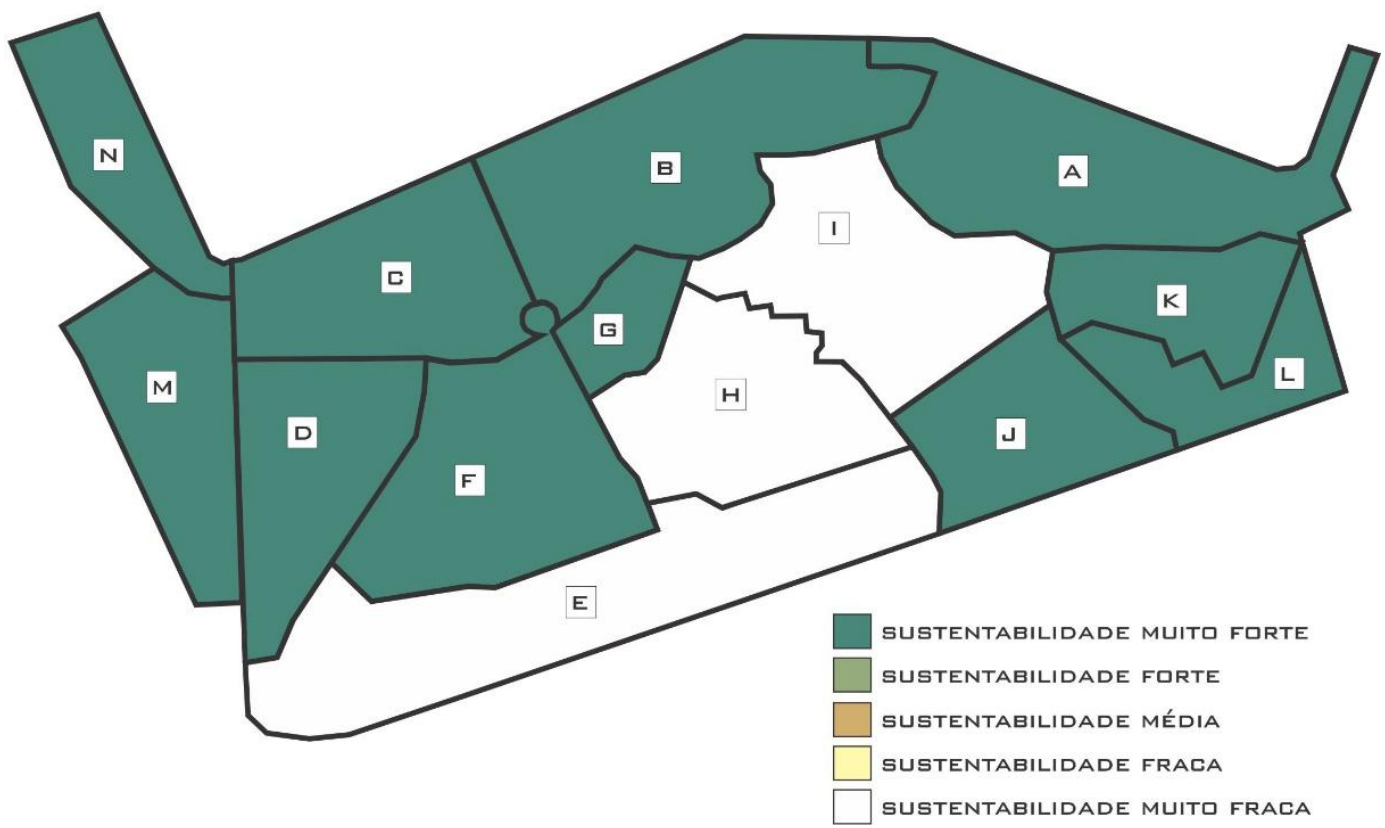

Figura 56 - Mapa de resíduos sólidos.

De acordo com as informações obtidas pela pesquisa, as regiões com pior serviço de coleta são: Morro da Providência (H), Livramento (H) e Central do Brasil (E). Segundo o projeto criado para o Porto Maravilha, a execução desse serviço deveria ser realizada pelo consórcio; no entanto, pela falta de liquidez (conforme reunião realizada com o representante da CDURP), atualmente o serviço é executado pela Comlurb (Anexo 3).

As demais áreas apresentam serviço regular de coleta, ainda que com algumas reclamações pontuais, que foram identificadas ao longo da pesquisa. 


\subsection{5.}

\section{Aprazibilidade}

\section{Relação forte (+3 pontos)}

- Definição, no projeto, de parâmetros construtivos de afastamento e gabarito que permitam a entrada de luz natural em todas as unidades de residência e trabalho

o Atingiram esse critério as áreas: A, B, C, D, E, F, I, M

- Instalação de iluminação artificial nas áreas públicas

o Atingiram esse critério as áreas: A, B, C, D, K, M, N

- Atendimento da área por ciclovias e calçadas que favoreçam o transporte não motor

o Atingiram esse critério as áreas: A, B, C, D

- Redução das vias geradoras de trânsito e ruídos no entorno

o Atingiram esse critério as áreas: A, B, F, H, I, K

- Plantio de novas árvores e áreas verdes

o Atingiram esse critério as áreas: A, B, C, D, J, L, M, N

- Redução do acúmulo de lixo nas calçadas

o Atingiram esse critério as áreas: A, B, C, D, F, G, J, K, L, M, N

- Atendimento de área por praças, centros esportivos e áreas de lazer com infraestrutura

o Atingiram esse critério as áreas: A, B, F, G, K

- Atendimento da espaços públicos acessíveis

o Atingiram esse critério as áreas: A, B, G

\section{Relação média (+2 pontos)}

- Atendimento da área por museus e centros culturais

o Atingiram esse critério as áreas: A, B, I, K 


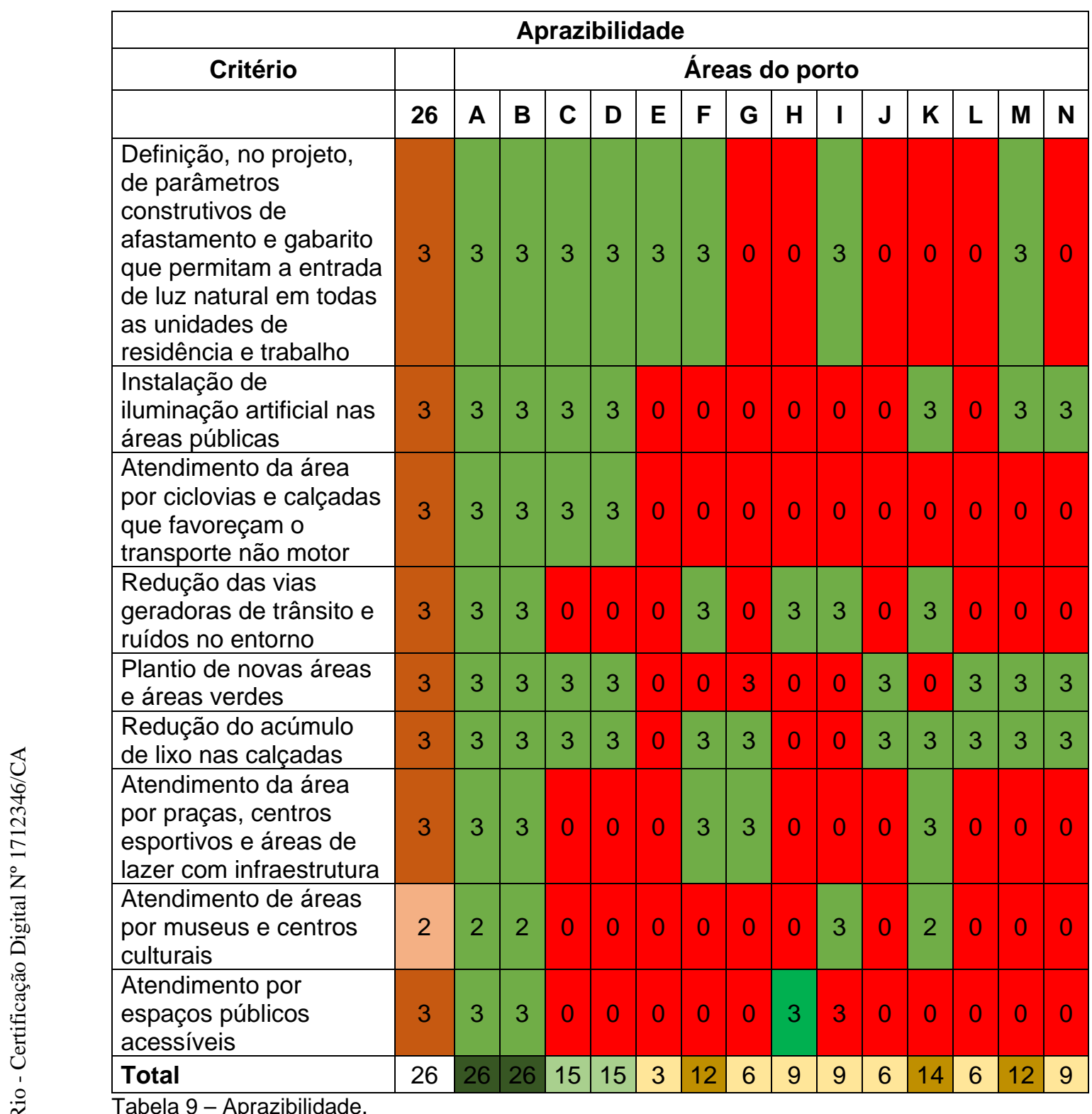




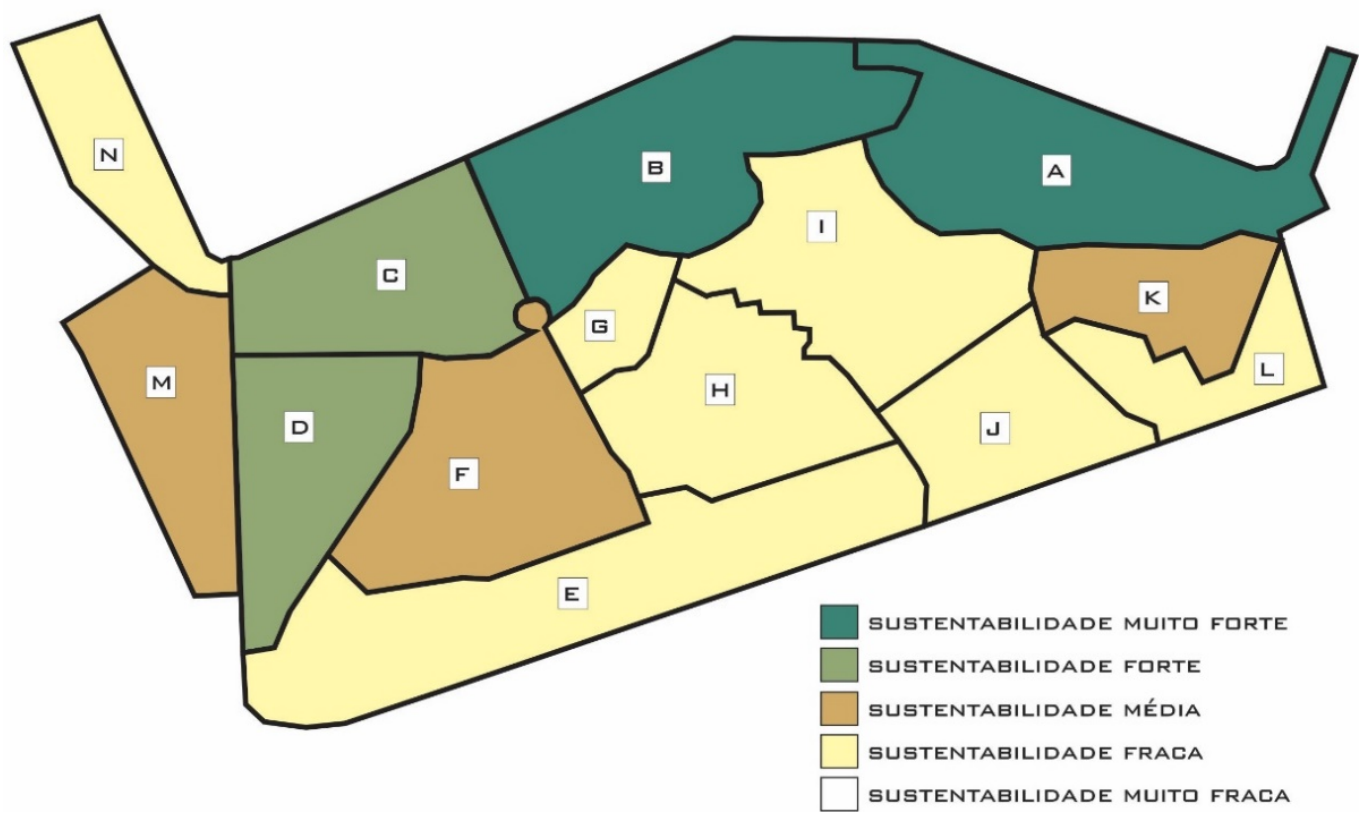

Figura 57 - Mapa de aprazibilidade.

Conforme descrito nos capítulos anteriores, a aprazibilidade consiste em construir espaços agradáveis, bonitos e funcionais. Espaços mais agradáveis tendem a ter mais vitalidade e, além de gerarem maior conexão com a identidade local, promovem uma melhoria no bem-estar e na sustentabilidade, bem como na capacidade de sobrevida do local.

De acordo com o mapa apresentado e dados levantados pela análise dos critérios, foi possível verificar que as áreas que receberam maior contribuição nessa categoria foram as áreas A e B — onde está localizado o Boulevard Olímpico. A área C, apesar de também ter a interferência do Boulevard, contempla vias geradoras de trânsito e pouca conectividade com o restante da região (conforme descrito no item Mobilidade), por ser uma área, de um lado, cercada pela Via Binário e, de outro, por grandes fachadas fechadas que impedem a conexão com a orla.

Durante as visitas de campo, foi possível identificar um grande contraste entre as áreas F (Morro do Pinto) e H (Morro da Providência). Enquanto a primeira recebeu as obras do Parque Machado de Assis (Figura 36), com três quadras e diversos equipamentos de lazer - incluindo uma quadra provisória pelo período das obras —, a outra teve sua única quadra removida e nenhum equipamento colocado no lugar (Figura 50). Foi possível verificar que as crianças acabam tendo 
de se apropriar de espaços pequenos e de passagem para esse fim (Figura $37^{18}$ ). A substituição da quadra pelo mirante do teleférico - que não funciona desde dezembro de 2016 — recebeu resistência por parte dos moradores, visto que a área mais próxima de lazer com infraestrutura para eles está no Parque Olímpico (região G) e demanda locomoção.

A qualidade do serviço de coleta de lixo também é visível nas duas áreas. Pelas visitas e pelos registros fotográficos apresentados ao longo do trabalho, foi possível verificar que, enquanto a primeira dispõe de um serviço regular e com lixeiras espalhadas por toda a região, a segunda apresentou muito lixo espalhado pela calçada (Figura 28) e, inclusive, diversas placas de sinalização dos moradores para não jogarem lixo em suas residências. A presença de vias geradoras de ruídos (Figura 20) e a falta de plantio de árvores na região (Figura 22) também são fatores que impactam negativamente a vitalidade e aprazibilidade dos espaços que tiveram menor contribuição nessa categoria.

\subsection{6. \\ Identidade e cultura}

\section{Relação forte (+3 pontos)}

- Valorização do patrimônio arquitetônico com presença significativa de imóveis tombados/preservados

o Atingiram esse critério as áreas: A, G, I, J, K, L

- Valorização e preservação de áreas arqueológicas

o Atingiram esse critério as áreas: A, C, E, I, K

- Atendimento de área por praças, centros esportivos e áreas de lazer com infraestrutura

o Atingiram esse critério as áreas: A, B, F, G, K

- Atendimento da área por museus e centros culturais

o Atingiram esse critério as áreas: A, B, I, K

- Participação da população envolvida em sua concepção

o Nenhuma área atingiu o critério

\footnotetext{
${ }^{18}$ É possível verificar, na Figura 37, que as crianças permanecem jogando bola na área onde antes foi uma quadra de futebol, removida antes do Porto Maravilha.
} 


\begin{tabular}{|c|c|c|c|c|c|c|c|c|c|c|c|c|c|c|c|}
\hline \multicolumn{16}{|c|}{ Identidade e cultura } \\
\hline \multirow[t]{2}{*}{ Critério } & \multicolumn{15}{|c|}{ Áreas do porto } \\
\hline & 15 & A & B & C & D & $\mathbf{E}$ & $\mathbf{F}$ & G & $\mathbf{H}$ & I & $\mathbf{J}$ & $\mathbf{K}$ & $\mathbf{L}$ & $M$ & $\mathbf{N}$ \\
\hline $\begin{array}{l}\text { Valorização do } \\
\text { patrimônio arquitetônico } \\
\text { com presença } \\
\text { significativa de imóveis } \\
\text { tombados/preservados }\end{array}$ & 3 & 3 & 0 & 0 & 0 & 0 & 0 & 3 & 0 & 3 & 3 & 3 & 3 & 0 & 0 \\
\hline $\begin{array}{l}\text { Valorização e } \\
\text { preservação de áreas } \\
\text { arqueológicas }\end{array}$ & 3 & 3 & 0 & 3 & 0 & 3 & 0 & 0 & 0 & 3 & 0 & 3 & 0 & 0 & 0 \\
\hline $\begin{array}{l}\text { Atendimento da área } \\
\text { por praças, centros } \\
\text { esportivos e áreas de } \\
\text { lazer com infraestrutura }\end{array}$ & 3 & 3 & 3 & 0 & 0 & 0 & 3 & 3 & 0 & 0 & 0 & 3 & 0 & 0 & 0 \\
\hline $\begin{array}{l}\text { Atendimento de áreas } \\
\text { por museus e centros } \\
\text { culturais }\end{array}$ & 3 & 3 & 3 & 0 & 0 & 0 & 0 & 0 & 0 & 3 & 0 & 3 & 0 & 0 & 0 \\
\hline $\begin{array}{l}\text { Participação da } \\
\text { população envolvida } \\
\text { em sua concepção }\end{array}$ & 3 & 0 & 0 & 0 & 0 & 0 & 0 & 0 & 0 & 0 & 0 & 0 & 0 & 0 & 0 \\
\hline Total & & 12 & 6 & 3 & 0 & 3 & 3 & 6 & 0 & 9 & 3 & 12 & 3 & 0 & 0 \\
\hline
\end{tabular}

Tabela 10 - Identidade e cultura.

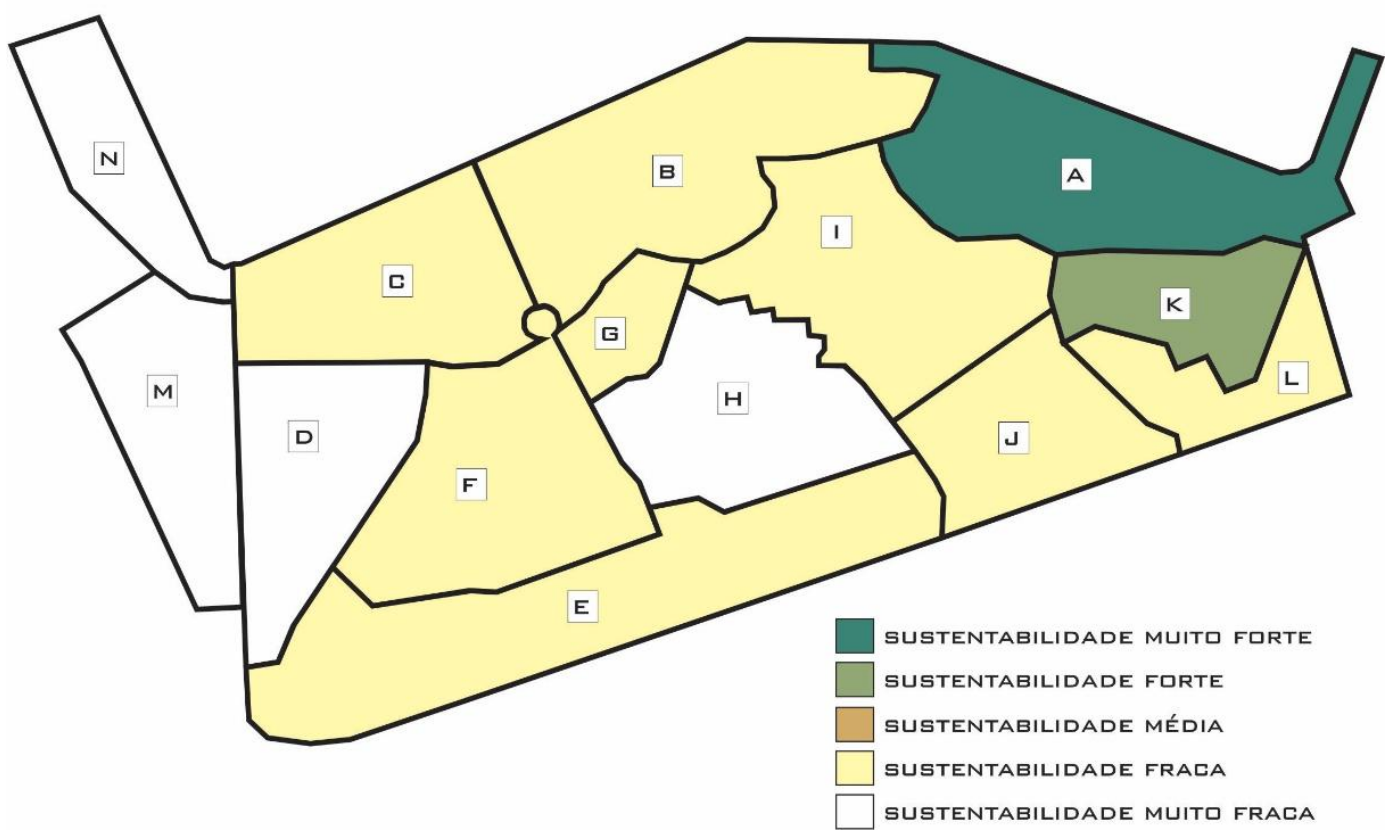

Figura 58 - Mapa de identidade e cultura.

A área A (Praça Mauá) foi a que teve melhor resultado na categoria identidade e cultura. Conforme verificado ao longo do trabalho, de acordo com a Lei Municipal n⿳0 101/2009, parte da verba obtida pela venda dos Cepacs deveria ser revertida para um fundo para projetos culturais na região. No entanto, de acordo com a entrevista 
realizada na CDURP (Anexo 3), a maior parte foi direcionada para o Museu do Amanhã e o MAR fazerem sua museologia (Anexo 3). Tal fato prejudicou boa parte dos projetos culturais que existiam na região.

Algumas regiões, como a K (Morro da Conceição ou Portinho), tem número expressivo de imóveis tombados ou preservados (Figura 31). Foi oferecido para os moradores da região que se cadastrassem na isenção de impostos até 2025. No entanto, o mesmo recurso não foi disponibilizado em outras regiões, conforme relatado pela entrevista com uma das sócias da Cia de Mystérios e descrito ao longo do trabalho. Segundo a entrevistada, que é uma das proprietárias do casario próximo à Praça Harmonia, alguns pequenos comércios locais e muito antigos na região não sobreviveram ao período das obras do VLT, que se prolongaram por mais de três anos, como foi o caso do pequeno restaurante de um português que afirmava não precisar de obras, mas apenas queria a isenção dos impostos no período que suas vendas tinham sido reduzidas.

O Circuito da Herança Africana (Figura 31), que inclui o Cais do Valongo (Figura 32) — indicado como Patrimônio da Humanidade pela Unesco —, realiza suas obras com recursos obtidos pelo Consulado Americano, visto que a Prefeitura não tem mais verbas para isso.

Segundo as entrevistas realizadas tanto com a arquiteta Claudia Escarlate presidente do Instituto Rio Patrimônio da Humanidade — quanto com o engenheiro Antônio Carlos — presidente da CDURP — , o fato de a maior parte da verba ter sido destinada ao Museu do Amanhã é o principal motivo para a falta de recursos para investimento nessas áreas, tendo, inclusive, sido apresentada uma planilha com essas informações ao Ministério Público.

Dessa forma, apesar de a região conter diversos projetos culturais independentes de grande valor para a cidade, como a Casa da Tia Ciata (Pedra do Sal), o Circuito da Herança Africana, o Projeto Filhos de Gandhi (Praça dos Estivadores), a Casa Amarela (Morro da Providência), a Favelarte (Morro da Providência), o Armazém Utopia (Boulevard) e o IPN (Praça Harmonia), poucos foram os recursos disponíveis para promover a identidade e a cultura da região como um todo. 


\subsection{7.}

\section{Diversidade}

\section{Relação forte (+3 pontos)}

- Atendimento da área por usos e equipamentos diversos

o Atingiu esse critério a área: $\mathrm{K}$

- Plantio de novas árvores e áreas verdes

o Atingiram esse critério as áreas: A, B, C, D, J, L, M, N

- Valorização do patrimônio arquitetônico com presença significativa de imóveis tombados/preservados

o Atingiram esse critério as áreas: A, G, I, J, K, L

- Valorização e preservação de áreas arqueológicas

o Atingiram esse critério as áreas: A, C, E, I, K

- Atendimento de área por praças, centros esportivos e áreas de lazer com infraestrutura

o Atingiram esse critério as áreas: A, B, F, G, K

- Atendimento da área por museus e centros culturais

o Atingiram esse critério as áreas: A, B, I, K

- Atendimento da espaços públicos acessíveis

o Atingiram esse critério as áreas: A, B, G

- Construção de novas moradias voltadas para habitação popular

o Atingiram esse critério as áreas: F, I

- Manutenção da população local, não se realizando remoções compulsórias

o Atingiram esse critério as áreas: C, E, F, G, J

- Participação da população envolvida em sua concepção

o Atingiram esse critério as áreas: 0

- Atendimento da área por escolas, creches e hospitais

o Atingiram esse critério as áreas: A, B, C, G, K

- Existência de diferentes padrões habitacionais, equipamentos e usos

o Nenhuma área atingiu o critério

\section{Relação média (+2 pontos)}

- Instalação de iluminação artificial nas áreas públicas

o Atingiram esse critério as áreas: A, B, C, D, K 
- Atendimento da área por pontos de ônibus e VLT

o Atingiram esse critério as áreas: A, B, C, D, E, G, J, L

- Atendimento da área por sistemas de transporte de massa

o Atingiram esse critério as áreas: E, J

- Atendimento da área por ciclovias e calçadas que favoreçam o transporte não motor

o Atingiram esse critério as áreas: A, B, C, D

\begin{tabular}{|l|l|l|l|l|l|l|l|l|l|l|l|l|l|l|l|l|}
\hline \multicolumn{70}{|c|}{ Diversidade } \\
\hline \multicolumn{1}{|c|}{ Critério } & 42 & A & B & C & D & E & F & G & H & I & J & K & L & M & N \\
\hline \begin{tabular}{l}
\hline Instalação de iluminação \\
artificial nas áreas \\
públicas
\end{tabular} & 2 & 2 & 2 & 2 & 2 & 0 & 0 & 0 & 0 & 0 & 0 & 2 & 0 & 2 & 2 \\
\hline $\begin{array}{l}\text { Atendimento da área por } \\
\text { pontos de ônibus e VLT }\end{array}$ & 2 & 2 & 2 & 2 & 2 & 2 & 0 & 2 & 0 & 0 & 2 & 0 & 2 & 0 & 0 \\
\hline $\begin{array}{l}\text { Atendimento da área por } \\
\text { sistemas de transporte de } \\
\text { massa }\end{array}$ & 2 & 0 & 0 & 0 & 0 & 2 & 0 & 0 & 0 & 0 & 2 & 0 & 0 & 0 & 0 \\
\hline $\begin{array}{l}\text { Atendimento da área por } \\
\text { ciclovias e calçadas que } \\
\text { favoreçam o transporte } \\
\text { não motor }\end{array}$ & 2 & 2 & 2 & 2 & 2 & 0 & 0 & 0 & 0 & 0 & 0 & 0 & 0 & 0 & 0 \\
\hline $\begin{array}{l}\text { Atendimento da área por } \\
\text { usos e equipamentos } \\
\text { diversos }\end{array}$ & 3 & 0 & 0 & 0 & 0 & 0 & 0 & 0 & 0 & 0 & 0 & 3 & 0 & 0 & 0 \\
\hline $\begin{array}{l}\text { Plantio de novas áreas e } \\
\text { áreas verdes }\end{array}$ & 3 & 3 & 3 & 3 & 3 & 0 & 0 & 0 & 0 & 0 & 3 & 0 & 3 & 3 & 3 \\
\hline $\begin{array}{l}\text { Valorização do patrimônio } \\
\text { arquitetônico com } \\
\text { presença significativa de } \\
\text { imóveis } \\
\text { tombados/preservados }\end{array}$ & 3 & 3 & 0 & 0 & 0 & 0 & 0 & 3 & 0 & 3 & 3 & 3 & 3 & 0 & 0 \\
\hline $\begin{array}{l}\text { Valorização e preservação } \\
\text { de áreas arqueológicas }\end{array}$ & 3 & 3 & 0 & 3 & 0 & 3 & 0 & 0 & 0 & 3 & 0 & 3 & 0 & 0 & 0 \\
\hline $\begin{array}{l}\text { Atendimento da área por } \\
\text { praças, centros esportivos } \\
\text { e áreas de lazer com } \\
\text { infraestrutura }\end{array}$ & 3 & 3 & 3 & 0 & 0 & 0 & 3 & 3 & 0 & 0 & 0 & 3 & 0 & 0 & 0 \\
\hline $\begin{array}{l}\text { Atendimento de áreas por } \\
\text { museus e centros } \\
\text { culturais }\end{array}$ & 3 & 3 & 3 & 0 & 0 & 0 & 0 & 0 & 0 & 3 & 0 & 3 & 0 & 0 & 0 \\
\hline $\begin{array}{l}\text { Atendimento por espaços } \\
\text { públicos acessíveis }\end{array}$ & 3 & 3 & 3 & 0 & 0 & 0 & 0 & 3 & 0 & 0 & 0 & 0 & 0 & 0 & 0 \\
\hline $\begin{array}{l}\text { Construção de novas } \\
\text { moradias voltadas para } \\
\text { habitação popular }\end{array}$ & 3 & 0 & 0 & 0 & 0 & 0 & 3 & 0 & 0 & 3 & 0 & 0 & 0 & 0 & 0 \\
\hline
\end{tabular}




\begin{tabular}{|l|l|l|l|l|l|l|l|l|l|l|l|l|l|l|l|}
\hline $\begin{array}{l}\text { Manutenção da população } \\
\text { local, não se realizando } \\
\text { remoções compulsórias }\end{array}$ & 3 & 0 & 0 & 3 & 0 & 3 & 3 & 3 & 0 & 0 & 3 & 0 & 0 & 0 & 0 \\
\hline $\begin{array}{l}\text { Participação da população } \\
\text { envolvida em sua } \\
\text { concepção }\end{array}$ & 3 & 0 & 0 & 0 & 0 & 0 & 0 & 0 & 0 & 0 & 0 & 0 & 0 & 0 & 0 \\
\hline $\begin{array}{l}\text { Atendimento da área por } \\
\text { escolas, creches e } \\
\text { hospitais }\end{array}$ & 3 & 3 & 3 & 3 & 0 & 0 & 0 & 3 & 0 & 0 & 0 & 3 & 0 & 0 & 0 \\
\hline $\begin{array}{l}\text { Existência de diferentes } \\
\text { padrões habitacionais, } \\
\text { equipamentos e usos }\end{array}$ & 3 & 0 & 0 & 0 & 0 & 0 & 0 & 0 & 0 & 0 & 0 & 0 & 0 & 0 & 0 \\
\hline Total & 44 & 27 & 21 & 18 & 9 & 10 & 9 & 17 & 0 & 12 & 13 & 20 & 8 & 5 & 5 \\
\hline
\end{tabular}

Tabela 11 - Diversidade.

\section{DIVERSIDADE}

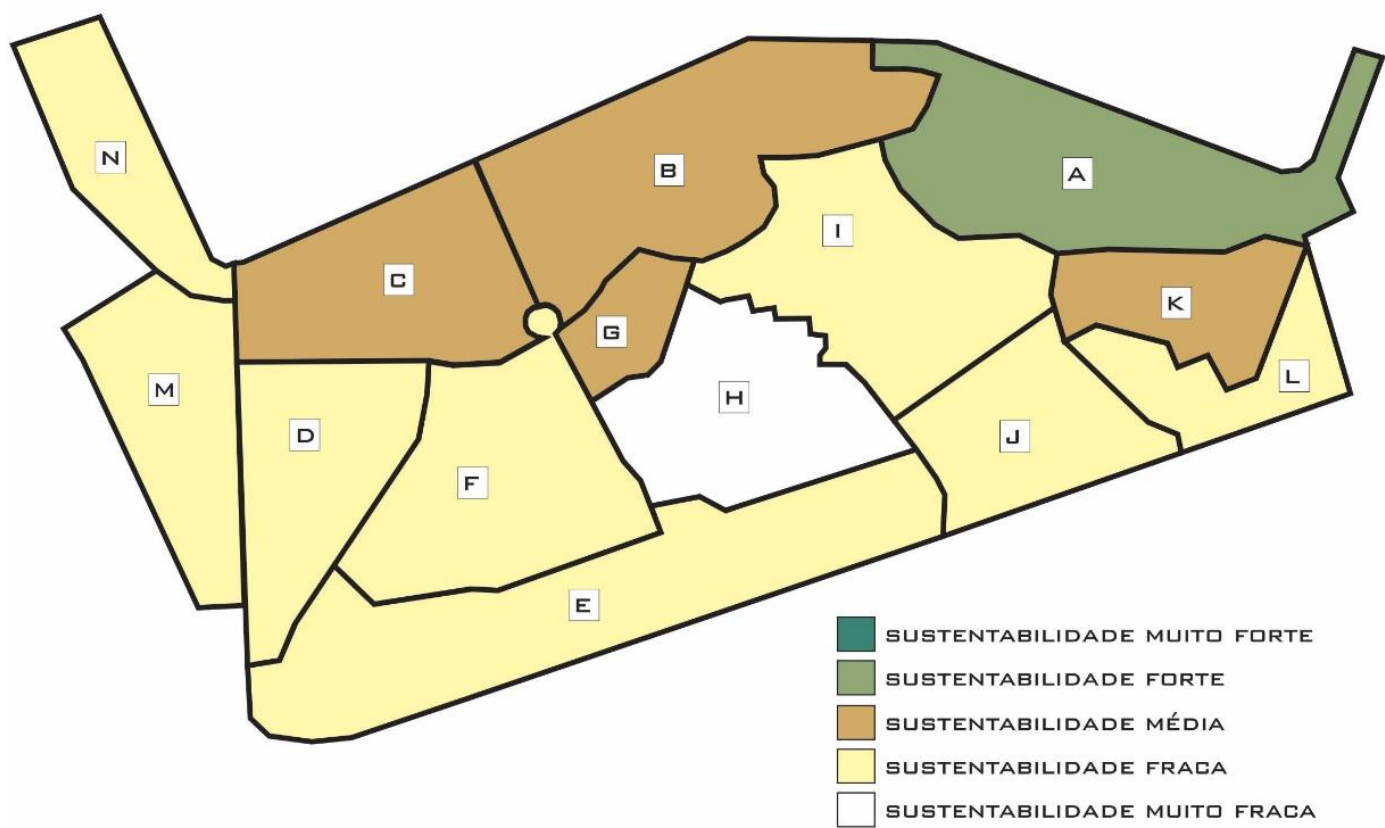

Figura 59 - Mapa de diversidade.

O mapa elaborado a partir dos critérios analisados indicou que a área $\mathrm{A}$ recebeu mais contribuições. A construção do VLT (Figura 17), de praças e ciclovias no local (Praça Mauá), museus (do Amanhã e MAR), bem como a existência de hospitais, escolas e outros equipamentos na região (Figura 21), foram os fatores que mais influenciaram o resultado, apesar da baixa diversidade de uso, visto que a área é predominantemente comercial (Figura 21). Mesmo com um resultado superior em comparação com as outras áreas, a área A atingiu apenas $61 \%$ dos critérios preestabelecidos (Tabela 11), negligenciando fatores muito importantes para a promoção da diversidade, como a construção de habitação popular, a promoção da 
diversidade de usos, a manutenção da população local sem remoções compulsórias e a participação da população na concepção do projeto.

Foram realizadas 70 entrevistas estruturadas nas áreas da Praça Mauá, do Boulevard e do AquaRio. Entre a população entrevistada, 75\% não moram no bairro, e aproximadamente a metade dos moradores que estavam na região estudada era ambulante. Ou seja, apenas aproximadamente 12\% da população entrevistada eram compostos por moradores que utilizam o espaço como área de lazer ou passagem. Tal fato indica que algumas áreas construídas para o Porto Maravilha, como é o caso dos museus e da Praça Mauá, não beneficiam diretamente a população local como espaços de convivência e lazer.

O mapa gerado (Figura 59) aponta ainda que o Porto Maravilha não contribuiu para a sustentabilidade em nenhum dos critérios de análise estabelecidos pela metodologia na categoria diversidade para o setor H (Morro da Providência), que teve o pior resultado. Foi possível verificar que as ações promovidas pelo projeto não só não contribuem para a melhoria da região, como também podem acabar impactando negativamente seu desenvolvimento nessa área. Como exemplo, a construção do teleférico na quadra localizada na Praça Américo Brum, que era o principal local de encontro e de lazer da população local.

No entanto, vale ressaltar que o resultado nulo nessa categoria não quer dizer que a área não tenha qualquer tipo de diversidade. Ao contrário, ela sobrevive, atualmente, com diversos projetos culturais que funcionam independentemente dos recursos do Porto Maravilha, como a Casa Amarela e o Favelarte - que promovem diversos eventos e cursos para a população do Morro da Providência. O resultado obtido pela análise do mapa indica que a implementação do Porto Maravilha não é responsável por contribuições positivas para a melhoria da área $H$, não tendo atendido a nenhum dos critérios preestabelecidos por este trabalho.

\subsection{8.}

\section{Inclusão e equidade}

\section{Relação forte ( +3 pontos)}

- Atendimento da área por usos e equipamentos diversos

o Atingiu esse critério a área: $\mathrm{K}$ 
- Atendimento da área por praças, centros esportivos e áreas de lazer com infraestrutura

o Atingiram esse critério as áreas: A, B, F, G, K

- Atendimento por espaços públicos acessíveis

o Atingiram esse critério as áreas: A, B, G

- Construção de novas moradias voltadas para habitação popular

o Atingiram esse critério as áreas: F, I

- Manutenção da população local, não se realizando remoções compulsórias

o Atingiram esse critério as áreas: C, E, F, G, J

- Participação da população envolvida em sua concepção

o Nenhuma área atingiu o critério

- Atendimento da área por escolas, creches e hospitais

o Atingiram esse critério as áreas: A, B, C, G, K

- Existência de diferentes padrões habitacionais, equipamentos e usos

o Nenhuma área atingiu o critério

\section{Relação média (+2 pontos)}

- Instalação de iluminação artificial nas áreas públicas

o Atingiram esse critério as áreas: A, B, C, D, K, M, N

- Atendimento da área por pontos de ônibus e VLT

o Atingiram esse critério as áreas: A, B, C, D, E, G, J, L

- Atendimento da área por ciclovias e calçadas que favoreçam o transporte não motor

o Atingiram esse critério as áreas: A, B, C, D

- Atendimento da área por sistemas de transporte de massa

o Atingiram esse critério as áreas: E, J

- Redução das vias geradoras de trânsito e ruído no entorno

o Atingiram esse critério as áreas: A, B, F, H, I, K

- Instalação de rede de água

o Atingiram esse critério as áreas: A, B, C, D, M, N

- Instalação de rede de esgoto e drenagem

o Atingiram esse critério as áreas: A, B, C, D, M, N

- Instalação de rede de esgoto e drenagem 
o Atingiram esse critério as áreas: A, B, C, D, M, N

- Aplicação de medidas para evitar alagamentos pelas chuvas ou elevação do nível no mar em regiões urbanizadas

o Atingiram esse critério as áreas: F, H, I, J, K, L

- Redução do acúmulo de lixo nas calçadas

o Atingiram esse critério as áreas: A, B, C, D, F, G, J, K, L, M, N

- Atendimento da área por museus e centros culturais

o Atingiram esse critério as áreas: A, B, K

\begin{tabular}{|l|l|l|l|l|l|l|l|l|l|l|l|l|l|l|l|}
\hline \multicolumn{10}{|c|}{ Inclusão e equidade } \\
\hline \multicolumn{1}{|c|}{ Critério } & 44 & A & B & C & D & E & F & G & H & I & J & K & L & M & N \\
\hline $\begin{array}{l}\text { Instalação de } \\
\text { iluminação artificial nas } \\
\text { áreas públicas }\end{array}$ & 2 & 2 & 2 & 2 & 2 & 0 & 0 & 0 & 0 & 0 & 0 & 2 & 0 & 2 & 2 \\
\hline $\begin{array}{l}\text { Atendimento da área } \\
\text { por pontos de ônibus e } \\
\text { VLT }\end{array}$ & 2 & 2 & 2 & 2 & 2 & 2 & 0 & 2 & 0 & 0 & 2 & 0 & 2 & 0 & 0 \\
\hline $\begin{array}{l}\text { Atendimento da área } \\
\text { por sistemas de } \\
\text { transporte de massa }\end{array}$ & 2 & 0 & 0 & 0 & 0 & 2 & 0 & 0 & 0 & 0 & 2 & 0 & 0 & 0 & 0 \\
\hline $\begin{array}{l}\text { Atendimento da área } \\
\text { por ciclovias e calçadas } \\
\text { que favoreçam o } \\
\text { transporte não motor }\end{array}$ & 2 & 2 & 2 & 2 & 2 & 0 & 0 & 0 & 0 & 0 & 0 & 0 & 0 & 0 & 0 \\
\hline $\begin{array}{l}\text { Redução das vias } \\
\text { geradoras de trânsito e } \\
\text { ruídos no entorno }\end{array}$ & 2 & 2 & 2 & 0 & 0 & 0 & 2 & 0 & 2 & 2 & 0 & 2 & 0 & 0 & 0 \\
\hline $\begin{array}{l}\text { Atendimento da área } \\
\text { por usos e } \\
\text { equipamentos diversos }\end{array}$ & 3 & 0 & 0 & 0 & 0 & 0 & 0 & 0 & 0 & 0 & 0 & 3 & 0 & 0 & 0 \\
\hline $\begin{array}{l}\text { Instalação de rede de } \\
\text { água }\end{array}$ & 2 & 2 & 2 & 2 & 2 & 0 & 0 & 0 & 0 & 0 & 0 & 0 & 0 & 2 & 2 \\
\hline $\begin{array}{l}\text { Instalação de rede de } \\
\text { esgoto e drenagem }\end{array}$ & 2 & 2 & 2 & 2 & 2 & 0 & 0 & 0 & 0 & 0 & 0 & 0 & 0 & 2 & 2 \\
\hline $\begin{array}{l}\text { Aplicação de medidas } \\
\text { para evitar alagamentos } \\
\text { pelas chuvas ou } \\
\text { elevação do nível no } \\
\text { mar em regiões } \\
\text { urbanizadas }\end{array}$ & 2 & 0 & 0 & 0 & 0 & 0 & 2 & 0 & 2 & 2 & 2 & 2 & 2 & 0 & 0 \\
\hline $\begin{array}{l}\text { Redução do acúmulo } \\
\text { de lixo nas calçadas }\end{array}$ & 2 & 2 & 2 & 2 & 2 & 0 & 2 & 2 & 0 & 0 & 2 & 2 & 2 & 2 & 2 \\
\hline $\begin{array}{l}\text { Atendimento da área } \\
\text { por praças, centros } \\
\text { esportivos e áreas de } \\
\text { lazer com infraestrutura }\end{array}$ & 3 & 3 & 3 & 0 & 0 & 0 & 3 & 3 & 0 & 0 & 0 & 3 & 0 & 0 & 0 \\
\hline $\begin{array}{l}\text { Atendimento de áreas } \\
\text { por museus e centros } \\
\text { culturais }\end{array}$ & 2 & 2 & 2 & 0 & 0 & 0 & 0 & 0 & 0 & 2 & 0 & 3 & 0 & 0 & 0 \\
\hline
\end{tabular}




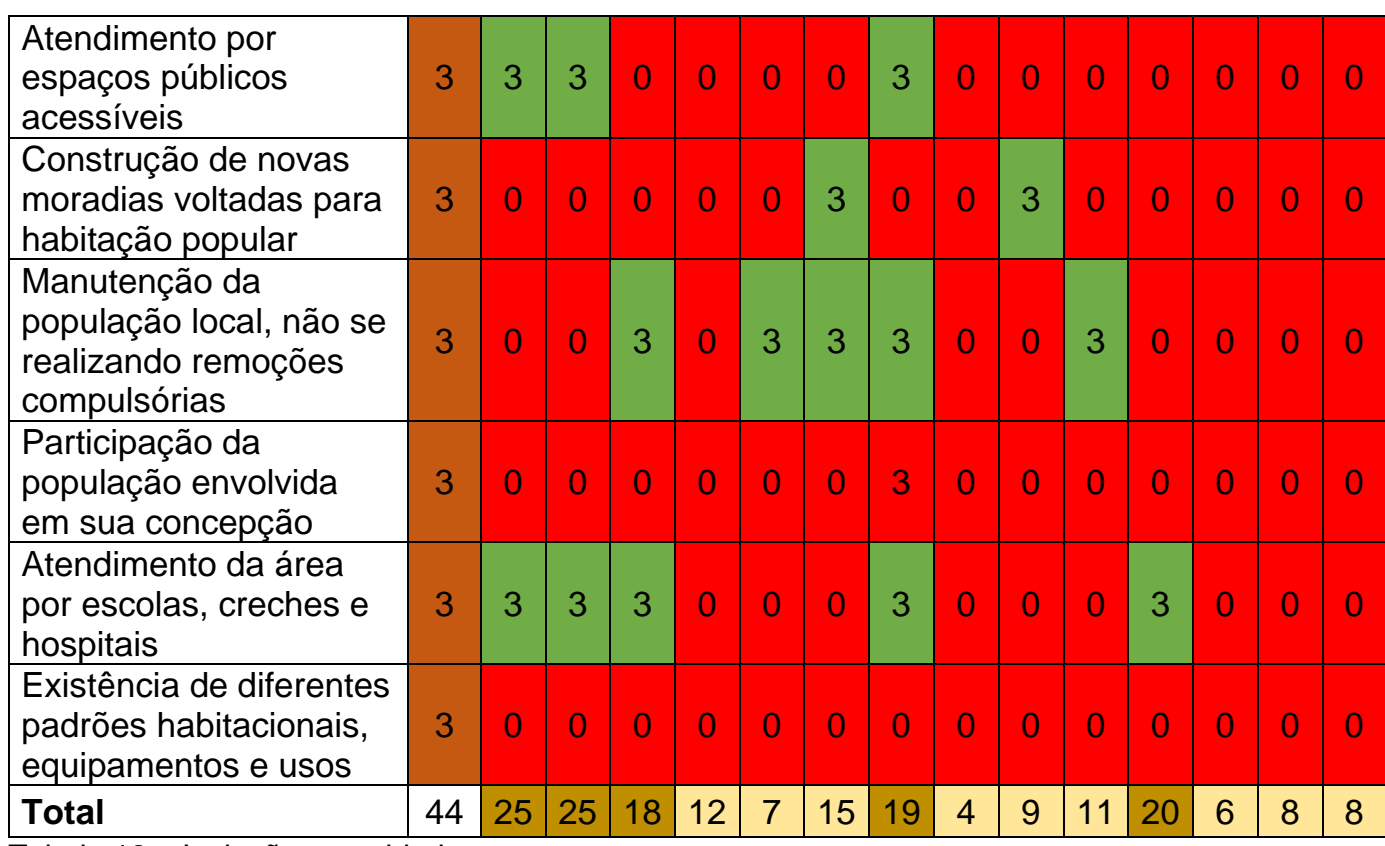

Tabela 12 - Inclusão e equidade.

INCLUSÃ̃ E EQUIDADE

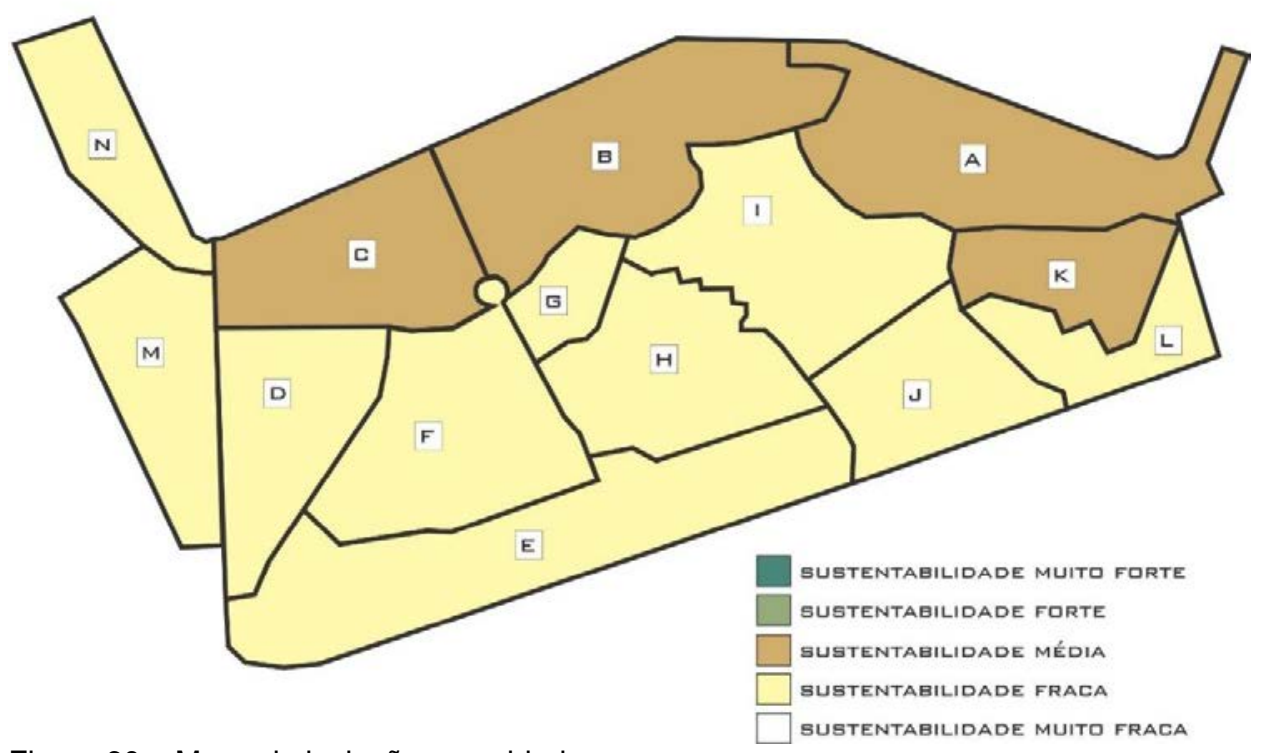

Figura 60 - Mapa de inclusão e equidade.

O mapa aponta que nenhuma área apresentou contribuição significativa para a promoção da categoria inclusão e equidade em toda a área do Porto Maravilha.

Nenhuma das áreas analisadas atingiu ao menos $60 \%$ dos critérios analisados preestabelecidos pela metodologia para a análise referentes ao critério.

Em razão dos investimentos em infraestrutura (Figura 14) e mobilidade (Figura 17), as áreas A, B, C, K apresentaram melhor desempenho em relação às demais. No entanto, vale salientar que esse resultado não é satisfatório, visto que - exceto pela área $\mathrm{K}$ - as áreas anteriormente citadas são de uso praticamente comercial (Figura 
21), não favorecendo, portanto, a melhoria das condições de vida dos moradores e da população existente no local onde foram realizadas as obras para o Porto Maravilha.

\section{5.}

\section{Resultado geral}

A partir da metodologia desenvolvida pela pesquisa e dos resultados obtidos pela análise de cada categoria individualmente, foi possível elaborar um mapa geral, que permite analisar como os critérios foram aplicados em cada região.

\begin{tabular}{|l|c|c|c|c|c|c|c|c|c|c|c|c|c|c|}
\hline \multicolumn{1}{|c|}{ Fonte } & \multicolumn{10}{|c|}{ Áreas do porto } \\
\hline & A & B & C & D & E & F & G & H & I & J & K & L & M & N \\
\hline $\begin{array}{l}\text { Eficiência } \\
\text { energética }\end{array}$ & 4 & 4 & 3 & 3 & 1 & 1 & 1 & 1 & 1 & 1 & 2 & 1 & 2 & 1 \\
\hline Poluição do ar & 4 & 4 & 3 & 2 & 1 & 1 & 1 & 1 & 1 & 1 & 1 & 1 & 1 & 1 \\
\hline $\begin{array}{l}\text { Recursos } \\
\text { hídricos }\end{array}$ & 3 & 3 & 3 & 3 & & 1 & 1 & 1 & 1 & 2 & 1 & 2 & 3 & 3 \\
\hline $\begin{array}{l}\text { Resíduos } \\
\text { sólidos }\end{array}$ & 4 & 4 & 4 & 4 & & 4 & 4 & & & 4 & 4 & 4 & 4 & 4 \\
\hline Aprazibilidade & 4 & 4 & 3 & 3 & 1 & 2 & 1 & 1 & 1 & 1 & 2 & 1 & 2 & 1 \\
\hline $\begin{array}{l}\text { Identidade e } \\
\text { cultura }\end{array}$ & 4 & 1 & 1 & & 1 & 1 & 1 & & 1 & 1 & 3 & 1 & & \\
\hline $\begin{array}{l}\text { Inclusão e } \\
\text { equidade }\end{array}$ & 2 & 2 & 2 & 1 & 1 & 1 & 2 & 1 & 1 & 1 & 2 & 1 & 1 & 1 \\
\hline Diversidade & 3 & 2 & 2 & 1 & 1 & 1 & 1 & & 1 & 1 & 2 & 1 & 1 & 1 \\
\hline Total & 28 & 24 & 21 & 17 & 6 & 12 & 12 & 5 & 7 & 12 & 17 & 12 & 14 & 12 \\
\hline
\end{tabular}

Tabela 13 - Resultado geral.

\section{ASPECTOS GERAIS}

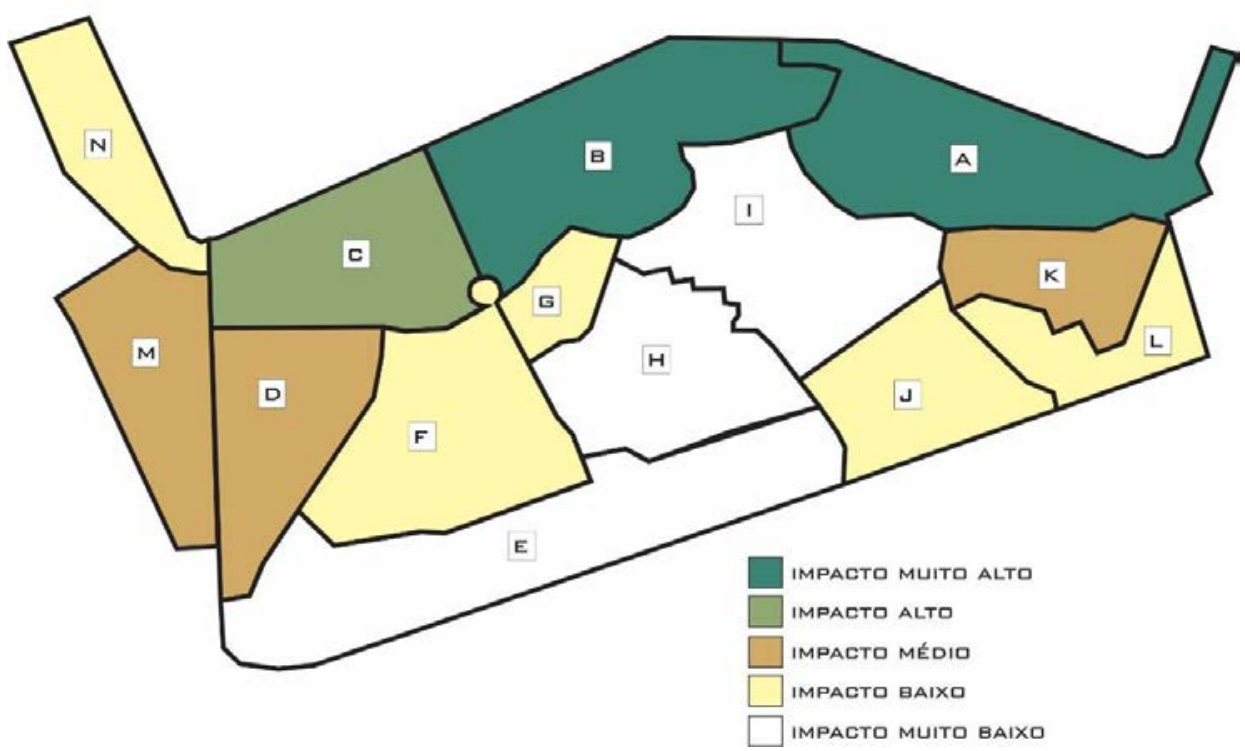

Figura 61 - Mapa de resultado final. 
A pesquisa partiu da hipótese de que os recursos que trariam maiores contribuições para a sustentabilidade local teriam sido destinados, principalmente, às regiões com maior retorno econômico. A partir do mapa elaborado com os resultados gerais (Figura 60), foi possível verificar que as áreas com maiores impactos positivos para a sustentabilidade são os setores A, B, C (Boulevard Olímpico), D e M (Porto Olímpico) e K (Portinho ou Morro da Conceição). As regiões N (Caju), F (Morro do Pinto), J e L (Centro) tinham impacto baixo, e as regiões E, H e I, impacto muito baixo.

Um dos possíveis motivos para esse fato pode ter sido que os recursos destinados à urbanização de outras áreas, como o Morro do Pinto e o Morro da Providência, foram transferidos para a construção do Museu do Amanhã e do MAR (Anexo 3), os quais pouco beneficiam a sustentabilidade do projeto como um todo.

De acordo com os dados apresentados, foi possível confirmar a hipótese criada pela presente pesquisa de que, visto que o projeto não tem distribuição adequada dos recursos aplicados, não poderia ser considerado sustentável de forma geral, pois não seria capaz de promover o desenvolvimento sustentável de maneira integrada, justa e equitativa. 


\section{5 \\ Conclusão}

Os múltiplos aspectos e escalas da crise pela qual atravessamos apontam que a crise ambiental é, na verdade, uma crise socioambiental. Para que seja possível compreendê-la de forma mais abrangente, devemos abandonar a ideia dualista e fragmentada do homem-natureza e homem-homem-natureza, substituindo-a por uma visão que integre o social e o natural junto aos projetos urbanos mais recentes.

A expressão desenvolvimento sustentável, em si, já indica um paradoxo relacionado com sua etimologia e entendimento. Enquanto a palavra desenvolvimento remete à ideia de movimento e de se des-envolver — ou seja, tirar o envolvimento - , a sustentabilidade conecta-se com a capacidade de se sustentar com seus próprios recursos.

O crescimento acelerado das cidades reproduz um modelo insustentável de urbanização. Dessa forma, faz-se necessário compreender o desenvolvimento sustentável como ferramenta primordial na elaboração de projetos urbanos mais inclusivos e sustentáveis, garantindo a duração e a sobrevivência das cidades e do meio ambiente com qualidade de vida para esta e para as futuras gerações.

Partindo da premissa de que cada sociedade tem uma realidade única, a pesquisa realizada parte do pressuposto de que existem diversos tipos de sustentabilidade, que vão variar de acordo com as características locais, de espaço e de tempo. É, portanto, fundamental que o projeto urbano respeite a identidade e a cultura de cada lugar, para que seja possível promover o desenvolvimento sustentável pela redução das desigualdades, pela manutenção das liberdades e pela melhoria do bem-estar.

A sustentabilidade tem caráter multidisciplinar em sua essência. Para que seja possível a elaboração de projetos mais sustentáveis, os diversos aspectos que os compõem devem ser incorporados de forma complexa e integrada. Não adianta, portanto, promover uma melhoria de determinado campo de atuação, enquanto outro for negligenciado. A omissão de determinado campo que estaria ligado a uma dimensão específica pode ressaltar ainda mais as desigualdades existentes no local. Esse é o caso, por exemplo, da ausência de moradias populares em uma região, que pode tanto interferir negativamente nos processos de inclusão e diversidade quanto 
impactar a eficiência energética e a poluição do ar — tendo em vista o possível aumento da demanda do número de viagens diárias entre a residência e o local de trabalho. Para que seja possível promover um desenvolvimento de fato sustentável, é, portanto, fundamental que todas as suas dimensões sejam consideradas na elaboração de projetos e planos urbanos.

A partir de uma análise geral dos mapas apresentados, nota-se que as regiões onde se localizam o Boulevard Olímpico (A, B e C) e o Porto Maravilha (D e M) apresentam maior contribuição para a sustentabilidade em diversas categorias, como eficiência energética, poluição do ar, recursos hídricos e aprazibilidade. Em contraste com essas áreas, as regiões onde atualmente reside grande parte da população consolidada - Morro da Providência (I e H), Morro do Pinto (F) e Santo Cristo (F) — permanecem com níveis muito baixos — algumas vezes nulos — nas mesmas categorias. A região da Central do Brasil (E) também obteve uma baixa contribuição para a sustentabilidade.

Também foi possível verificar que o Porto Maravilha teve contribuição baixa para a dimensão sociocultural de forma geral. Na análise das categorias inclusão $e$ equidade e diversidade, nenhuma das regiões em toda a área do projeto conseguiu atender pelo menos a $80 \%$ dos critérios preestabelecidos. A concentração da maior parte dos recursos financeiros, que seriam destinados a projetos culturais, para a construção do Museu do Amanhã e do MAR garantiu que a área da Praça Mauá (A) tivesse um melhor resultado para a categoria identidade e cultura. No entanto, acabou deixando as demais áreas, exceto a região do Morro da Conceição e da Pedra do Sal (K), com resultados inferiores a 40\% dos critérios atendidos para esse aspecto.

No que tange à aprazibilidade, as áreas da orla onde foi construído o Boulevard (A e B) também tiveram a maior contribuição com relação às demais. Em contrapartida, as regiões do Morro da Providência e da Central do Brasil (H e E) tiveram contribuição baixa, atendendo apenas a 12\% dos critérios relacionados que foram determinados para a metodologia aplicada.

De forma geral, foi possível verificar que as áreas com maior investimento em recursos urbanos tiveram também maior contribuição para a sustentabilidade da região. Em todas as categorias analisadas, a região da Praça Mauá (A), por exemplo, teve resultado superior ou igual ao das demais áreas. No entanto, tais desempenhos não são suficientes para garantir o desenvolvimento sustentável em todas as categorias analisadas, tendo em vista a omissão, em todo o projeto, de critérios importantes para 
o desenvolvimento sustentável, como participação da população envolvida em sua concepção e existência de diferentes padrões habitacionais, equipamentos.

Aproximadamente 76\% dos moradores entrevistados acreditam que o Porto Maravilha melhorou suas vidas total ou parcialmente. No entanto, foi possível identificar que, dos moradores que afirmam terem melhorias com o projeto, 85\% foram entrevistados nas regiões A, B e K, que receberam mais investimentos em infraestrutura. Em muitas situações, foi possível, inclusive, verificar um impacto negativo em alguns pontos, como é o caso do sistema de transportes.

Tendo em vista o exposto, o trabalho considerou as múltiplas relações que podem existir entre os critérios preestabelecidos pela metodologia e as dimensões propostas abordadas. Cada critério analisado pode, portanto, relacionar-se com mais de uma categoria de forma diferente. A pesquisa considera ainda que, para que um projeto possa contribuir para a sustentabilidade urbana, ele deve impulsionar uma distribuição justa e equitativa dos recursos aplicados em toda a região.

Com base nos dados, foi possível verificar que o projeto do Porto Maravilha não contribui de forma homogênea para a sustentabilidade da região estudada.

A limitação de tempo para a elaboração de uma pesquisa de campo participativa e etnográfica foi um dos problemas encontrados durante o desenvolvimento do trabalho. Tendo em vista a quantidade de informações técnicas a serem analisadas em paralelo e a dificuldade de acessar alguns locais da região estudada, bem como a reatividade por parte dos moradores, foi impossível a realização de um número superior de entrevistas.

Como contribuição acadêmica, além dos resultados obtidos pela dissertação apresentada, a pesquisa pode também servir como base metodológica para futuros trabalhos que contemplem tanto a atualização dos critérios estudados e o acompanhamento pós-ocupação quanto uma análise entre projetos similares, a fim de promover a elaboração de projetos urbanos mais sustentáveis. 
6

\section{Referências bibliográficas}

ACIOLY, C.; DAVIDSON, F. Densidade urbana: um instrumento de planejamento e gestão urbana. Rio de Janeiro: Mauad/IHS, 1998.

ALVA, E. N. Metrópoles (in)sustentáveis. Rio de Janeiro: Relume-Dumará, 1997. ARANTES, O. B. F. Uma estratégia fatal. In: ; VAINER, C.; MARICATO,

E. A cidade do pensamento único. Petrópolis: Vozes, 2000.

ARENDT, H. A condição humana. Tradução de Roberto Raposo. 10. ed. Rio de Janeiro: Forense Universitária, 2005.

ASCELRAD, H. (Org.). A duração das cidades: sustentabilidade e risco nas políticas urbanas. 2. ed. Rio de Janeiro: Lamparina, 2009-2011.

Discursos da sustentabilidade urbana. Revista Brasileira Estudos

Urbanos Regionais, n. 1, p. 78-90, maio 1999.

BARCZAK, R.; DUARTE, F. Impactos ambientais da mobilidade urbana: cinco categorias de medidas mitigadoras. Revista Brasileira de Gestão Urbana (Brazilian Journal of Urban Management), v. 4, n. 1, p. 13-32, jan./jun. 2012. BECK, U. Risk society: towards a new modernity. Londres, 1992.

BEZERRA, R. M.; FILHO, D. B. F.; SILVA, L. E. O. Desigualdade, qualidade de moradia e desenvolvimento humano nos municípios brasileiros. In: I SEMINÁRIO INTERNACIONAL DE CIÊNCIA POLÍTICA. Anais... Porto Alegre: Universidade Federal do Rio Grande do Sul, set. 2015.

BRAGA, R. B. Elementos para a compreensão da crise socioambiental. Élisée, Rev. Geo., Anápolis: UEG, v. 2, n. 2, p. 142-153, jul./dez. 2013.

CARVALHO, M. Cidade global: anotações críticas sobre um conceito. São Paulo em Perspectiva: Revista da Fundação Seade, São Paulo, v. 14, n. 4, out./dez. 2000. COMISSÃO MUNDIAL SOBRE MEIO AMBIENTE E DESENVOLVIMENTO. Nosso futuro comum. 2. ed. Rio de Janeiro: Fundação Getulio Vargas, 1991.

CUNHA, G. F. et al. Princípio da precaução no Brasil após a Rio-92: impacto ambiental e saúde humana. Ambiente e Sociedade, São Paulo, v. XVI, n. 3, 2013. DANSEREAU, P. Uma preparação ética para a mudança global: prospecção ecológica e prescrição moral. In: VIEIRA, P. F.; RIBEIRO, M. A. (Org.). Ecologia humana, ética e educação: a mensagem de Pierre Dansereau. Florianópolis: Aped, 1999. p. 299-370.

DE LA GARZA, M. Conexiones entre la Barbelona post-olimpica y el Rio préolimpico a través de la resisténcia a planes urbanísticos. In: CUNHA, N.; FREIRE, L. L.; MACHADO-MARTINS, M.; VEIGA, F. Antropologia do conflito urbano: conexões Rio-Barcelona. Niterói: Intertexto, 2015.

DIAS, G. F. Pegada ecológica e sustentabilidade humana. 1. ed. digital. São Paulo: Gaia, 2013.

DUBOIS-MAURY, J.; CHALINE, C. Les risques urbains. Paris: Armand Colin, 2002.

EMELLIANOFF, C. Les villes durables, l'emergence de nouvelles pemporalités dans de vieux espaces urbains. Écologie Politique, Paris, n. 13, p. 47-58, 1995.

FARR, D. Sustainable urbanismo: urban design with nature. Nova Jersey: John Wiley \& Sons, Inc. Hoboken, 2008. 
FERNANDES, V.; SAMPAIO, C. A. C. Problemática ambiental ou problemática socioambiental? A natureza da relação sociedade/meio ambiente. Desenvolvimento e Meio Ambiente, UFPR, n. 18, p. 87-94, jul./dez. 2008. FERRARI, C. Curso de planejamento municipal integrado. São Paulo: Livraria Pioneira, 1979.

GIDDENS, A. A política da mudança climática. Rio de Janeiro: Zahar, 2010. GIRARDET, H. Sustainables cities. Madri: Celestial, 2001.

GODARD, O. Environnement soutenable et développement durable: le modèle néo-classique en question. Environnement et Société, Paris: Cired, n. 91, 1991.

HERZOG, C. P.; ROSA, L. Z. Infraestrutura verde: sustentabilidade e resiliência para a paisagem urbana. Revista Labverde, São Paulo, n. 1, p. 92-115, set. 2010. HORKHEIMER, M. Eclipse da razão. São Paulo: Centauro, 2002.

IZAGA, F. Os infortúnios da Perimetral e as aspirações das vias urbanas nas novas dinâmicas territoriais do Rio de Janeiro pós grandes eventos. In: ENANPUR. Sessão Temática 3: Produção e Gestão do Espaço Urbano, Metropolitano e Regional. Anais... São Paulo, 2017.

JACOBS, J. A autodestruição da diversidade. In: Morte e vida de grandes cidades. São Paulo: Martins Fontes, 2011.

JONAS, H. Memórias. Madrid: Losada, 2005.

O princípio responsabilidade: ensaio de uma ética para a civilização tecnológica. Rio de Janeiro: Contraponto, 2006.

KOTHARI, R. Environment, technology and ethics. In: ENGEL, J. R.; ENGEL, J. G. (Ed.). Ethics of environment and development. Tucson: The University of Arizona Press, 1990.

LEFEBVRE, H. O direito à cidade. São Paulo: Moraes, 1991 [1968].

LEFF, E. Pensar la complejidad ambiental. In: LEFF, E. (Coord.). La complejidad ambiental. México: Siglo XXI/Unam/Pnuma, 2000.

LEITE, C. Cidades sustentáveis, cidades inteligentes: desenvolvimento sustentável num planeta urbano. Porto Alegre: Bookman, 2012.

LEME, F.; TREVIZAN, S. D. P. O resgate da identidade cultural: meio para uma sustentabilidade local. Revista Internacional de Desenvolvimento Local, v. 7, n. 12, p. 101-110, mar. 2006.

LEMOS, M. F. Adaptação de cidades para mudança climática: uma metodologia de análise para os planos diretores municipais. 2010. 260 f. Tese (Doutorado em Urbanismo), Universidade Federal do Rio de Janeiro, Rio de Janeiro, 2010a.

O futuro das cidades. Aula ministrada na disciplina Projeto de Cidades

Resilientes, Mestrado em Arquitetura da PUC-Rio, Rio de Janeiro, mar. 2018.

Planejamento urbano para enfrentamento de riscos ambientais, redução de vulnerabilidade sócio-climática e adaptação de cidades. In: I ENCONTRO DA ASSOCIAÇÃO NACIONAL DE PESQUISA E PÓS-GRADUAÇÃO EM ARQUITETURA E URBANISMO. Urbanismo na Sociedade de Risco: Violência Urbana e Vulnerabilidade Ambiental. Anais... Rio de Janeiro, 2010b.

Sustentabilidade e resiliência. In: III ENCONTRO DA ASSOCIAÇÃO NACIONAL DE PESQUISA E PÓS-GRADUAÇÃO EM ARQUITETURA E URBANISMO. Arquitetura, cidade e projeto: uma construção coletiva. Anais... São Paulo, 2014.

MACHADO, J. G. R; PAMBPLONA, J. B. A ONU e o desenvolvimento econômico: uma interpretação das bases teóricas da atuação do PNUD. Economia e Sociedade, Campinas, v. 17, n. 1 (32), p. 53-84, abr. 2008.

MASCARO, J. L. Loteamentos urbanos. Porto Alegre: Edição do Autor, 2005. 
MATURANA, H. R.; VARELA, F. J. A árvore do conhecimento: as bases biológicas da compreensão humana. São Paulo: Athena, 2001.

MENDONÇA, F. Impactos socioambientais urbanos. Curitiba: UFPR, 2004. MÉSZÁROS, I. O desafio do desenvolvimento sustentável e a cultura da igualdade substantiva. Texto lido na Conferência da Cúpula dos Parlamentares Latino-americanos. Caracas, 2001.

NOBRE, E. A. C. Desenho urbano: da teoria ao projeto. São Paulo: FAU/USP, 2004.

OPPENHEIMEIER, M.; CAMPOS, M.; WARREN, R.; BIRKMANN, J.; LUBER, G.; O’NEILL, B.; TAKAHASHI, K. Emergent risks and key vulnerabilities. In: FIELD, C. B. et al. (Ed.). Climate change 2014: impacts, adaptation, and vulnerability. Part A: global and sectoral aspects. Contribution of Working Group II to the Fifth Assessment Report of the Intergovernmental Panel on Climate Change. Cambridge (UK)/Nova York: Cambridge University Press, 2014. p. 10391099.

ORGANIZAÇÃO DAS NAÇÕES UNIDAS (ONU). Objetivos de desenvolvimento sustentável (ODS). [s.d.]. Disponível em: $<$ http://www.agenda2030.com.br/>. Acesso em: 18 jul. 2018.

ORSI, R. A. A crise sócio-ambiental e os novos desafios para o planejamento urbano. In: 12ํㅡㄹ ENCONTRO DE GEÓGRAFOS DA AMÉRICA LATINA. Anais..., 2009.

PORTO-GONÇALVES, C. W. A globalização da natureza e a natureza da globalização. Rio de Janeiro: Civilização Brasileira, 2006.

. O desafio ambiental. In: SADER, E. (Org.). Os porquês da desordem mundial: mestres explicam a globalização. Rio de Janeiro: Record, 2016.

RATTNER, H. Prefácio. In: ACSELRAD, H. A duração das cidades: sustentabilidade e risco nas políticas urbanas. 2. ed. Rio de Janeiro: Lamparina, 2011.

RICHARDSON, R. J. Pesquisa social: métodos e técnicas. 3. ed. São Paulo: Atlas, 1999.

ROGERS, R.; GUMUCHDJIAN, P. Cidades para um pequeno planeta. Barcelona: Gustavo Gili, 2001.

ROLNIK, R. Guerra dos lugares: a colonização da terra e da moradia na era das finanças. São Paulo: Boitempo, 2015.

RUTTER, M. Somos moldados pela natureza ou pelo meio?. In: SWAIN, H. (Org.). Grandes questões da ciência. Rio de Janeiro: José Olympio, 2010.

SACHS, I. Desenvolvimento: includente, sustentável, sustentado. Rio de Janeiro: Garamond, 2008.

Estratégias de transição para o século XXI: desenvolvimento e meio ambiente. São Paulo: Studio Nobel/Fundap, 1993.

SALAS-ZAPATA, W.; RÍOS-OSORIO, L.; CASTILLO, J. A. D. La ciencia emergente de la sustentabilidad: de la práctica científica hacia la constitución de una ciencia. Interciencia, v. 2, n. 9, 2011.

SÁNCHEZ, F. A (in)sustentabilidade das cidades vitrine. In: ACSELRAD, H. (Org.). A duração das cidades: sustentabilidade e risco nas políticas urbanas. 2. ed. Rio de Janeiro: Lamparina, 2009.

Buscando um lugar ao sol para as cidades: o papel das atuais políticas de promoção urbana. Revista Paranaense de Geografia, n. 4, 1999.

; GUTERMAN, B. Batalhas simbólicas na cena pública: a marcha para "Rio 2016”. In: CUNHA, N.; FREIRE, L. de L.; MACHADO-MARTINS, M.; VEIGA, 
F. (Org.). Antropologia do conflito urbano: conexões Rio-Barcelona. Niterói: Intertexto, 2015. p. 40-50.

SÁNCHEZ, L. E. Avaliação de impacto ambiental, conceitos e métodos. São Paulo: Oficina de Textos, 2013.

SANTOS, M. A natureza do espaço: técnica e tempo, razão e emoção. 4. ed. São Paulo: Universidade de São Paulo, 2006.

SARTORI, S.; LATÔNICO, F.; CAMPOS, L. M. S. Sustentabilidade e desenvolvimento sustentável: uma taxonomia no campo da literatura. Ambiente \& Sociedade, São Paulo, v. XVII, n. 1, p. 1-22, jan./mar. 2014.

SASSEN, S. As cidades na economia mundial. São Paulo: Studio Nobel, 1998.

SEN, A. A ideia de justiça. Tradução de Denise Bottmann. São Paulo: Companhia das Letras, 2011.

Desenvolvimento como liberdade. Tradução de Laura Teixeira Mota. São

Paulo: Companhia das Letras, 2010.

SERRES, M. O contrato natural. Lisboa: Instituto Piaget, 2000.

SILVA, L. O. A ocupação do espaço construído e qualidade ambiental: o caso da cidade de SP. São Paulo: Pólis Publicações, 1991. 3.

SILVA, S. R. M. Indicadores de sustentabilidade urbana, as perspectivas e as limitações da operacionalização de um referencial sustentável. Dissertação (Mestrado), Universidade Federal de São Carlos, São Carlos, 2000.

SMITH, N. The new urban frontier: gentrification and the revanchist city. Nova York Routledge, 1996.

SOUZA, M. L. Mudar a cidade: uma introdução crítica ao planejamento e à gestão urbanos. Rio de Janeiro: Bertrand Brasil, 2002.

TEEB - A Economia dos Ecossistemas e da Biodiversidade para Formuladores de Políticas Locais e Regionais, 2010

THOMAS, R. Sustainable urban design: an environmental approach. Londres: Spon Press, 2003.

TICKELL, C. Introdução. In: ROGERS, R. Cidades para um pequeno planeta. Barcelona: Gustavo Gili, 2001.

TRAJANO, E. Políticas de conservação e critérios ambientais: princípios conceitos e protocolos. Revista Estudos Avançados, São Paulo, v. 24, n. 68, 2010.

UN-HABITAT. Planning sustainable cities: global report on human settlements 2009. Washington: Earthscan, 2009.

UN-HABITAT III. Résilience urbaine: issue papers. Nova York, 2015. Disponível em: <http://imacitychanger.unhabitat.org/>. Acesso em: 2 jul. 2018.

UZZEL, D. B. Place identification, social cohesion, and environmental sustainability. Environment and Behavior, v. 34, n. 1, p. 26-53, jan. 2002.

VAINER, C. Notas metodológicas sobre a análise de grandes projetos urbanos. In: OLIVEIRA, F. L. de (Org.). et al. Grandes projetos metropolitanos: Rio de Janeiro e Belo Horizonte. Rio de Janeiro: Letra Capital, 2012.

VEYRET, Y. Os riscos. São Paulo: Contexto, 2007.

WILMOTH, J. Global demographic projections: future trajectories and associated uncertainty. Washington, DC. Disponível em: $<$ http://www.un.org/en/development/desa/population/about/director/pdf/March20 15_GlobalDemographicProjections_WorldBank.pdf>. Acesso em: 18 jul. 2018.

XIMENES, L. A. Ocupações na zona portuária do Rio de Janeiro: soluções de moradia e ações de resistência no contexto de implementação do Projeto Porto Maravilha. 2017. Monografia (Graduação) — Instituto de Filosofia e Ciências Humanas, Universidade Estadual do Rio de Janeiro, Rio de Janeiro, 2017. 
ZENGHELIS, D.; STERN, N. Climate change and cities: a prime source of problems, yet key to a solution. The Guardian, Londres. Disponível em: $<$ https://www.theguardian.com/cities/2015/nov/17/cities-climate-changeproblems-solution>. Acesso em: 18 jul. 2018. 
Anexo 1 - Planta geral das obras executadas fornecida pela CDURP

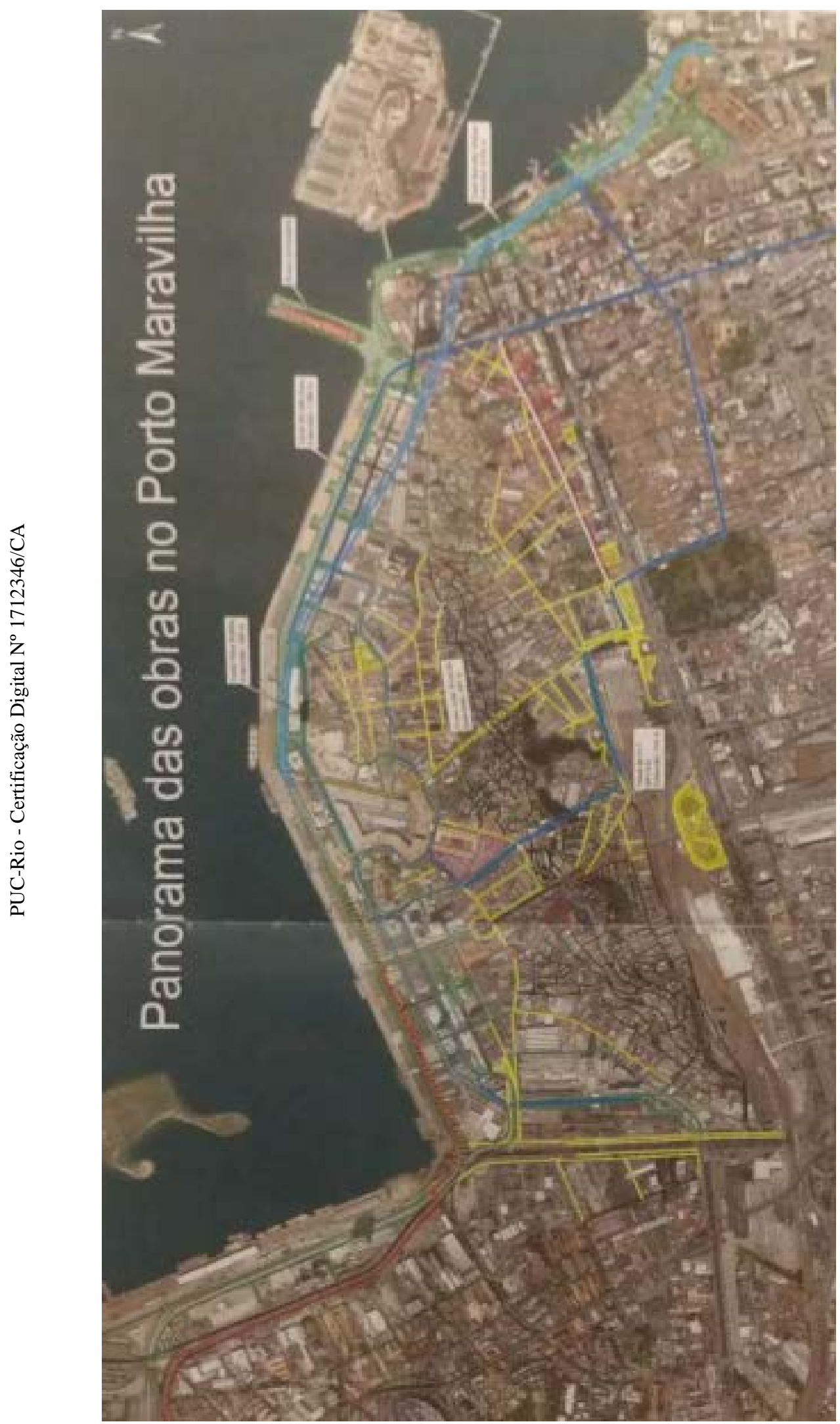


Anexo 2 - Planta de gabaritos propostos fornecida pela CDURP

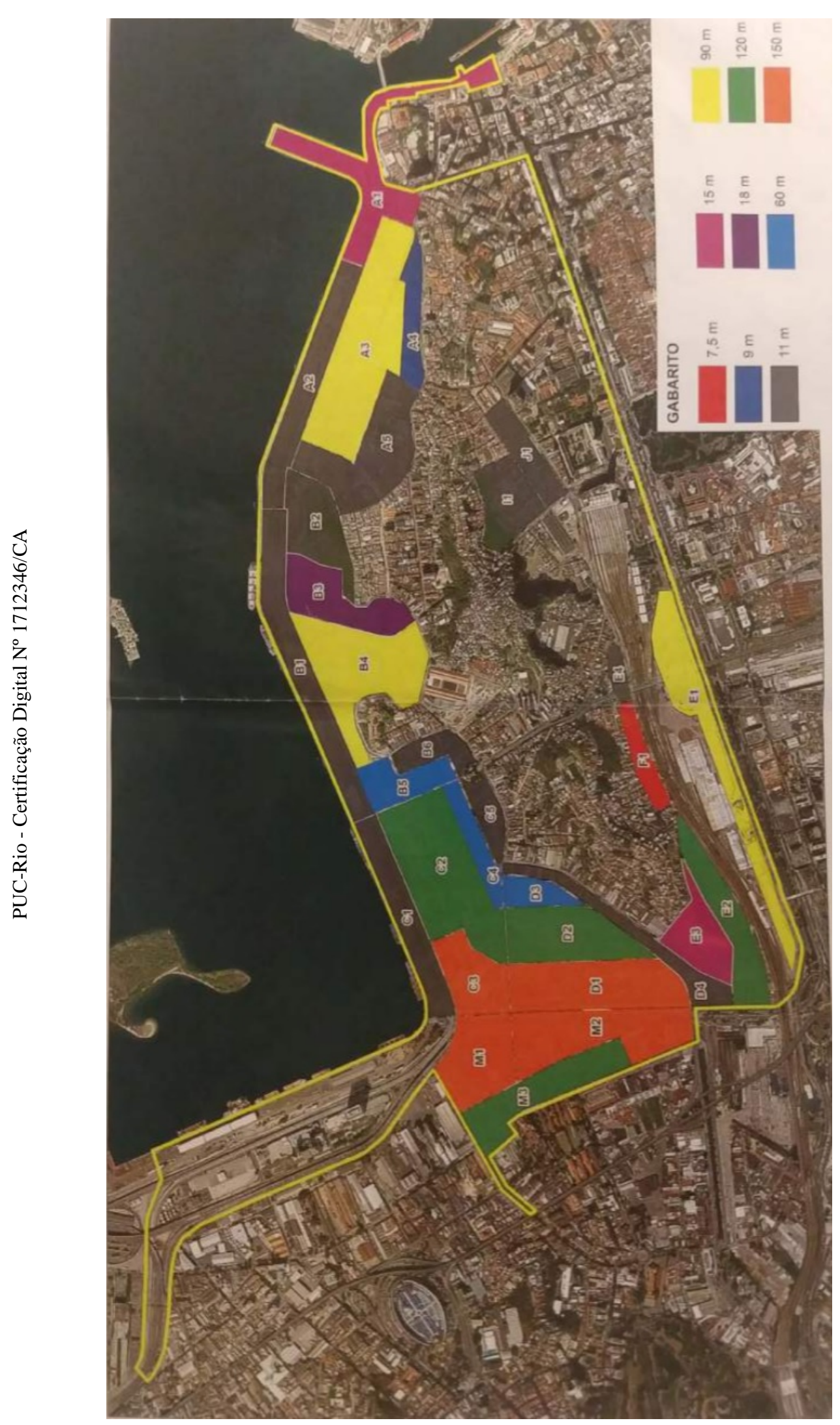




\section{Anexo 3 - Entrevista com o engenheiro civil Antônio Carlos, diretor e presidente da CDURP}

Vou começar a gravar. Hoje é dia 20 de março, são 15h30. Com Antônio Carlos, diretor presidente da CDURP. Então, eu gostaria que você falasse qual o papel da CDURP na concepção do Porto Maravilha.

Essa história começa em 2009, com a Lei Complementar $\mathrm{n}^{\mathrm{0}}$ 101, que definiu o perímetro da operação urbana consorciada da região do porto, uma região de 5 milhões e pouco de metros quadrados, e foram definidos os gabaritos e setores de potencial de consumo de Cepac de cada área. A princípio, a lei determinou que em cada área o índice de aproveitamento de terreno seria a partir daquele momento igual a 1. E, se quisessem construir em determinadas áreas, teria que ser paga uma outorga, que seria através do Cepac, que são Certificados de Potencial Adicional de Construção, e as outras áreas que não são delimitadas para isso são áreas que têm que ser preservadas; não pode ser construído lá. Se houver aumento de construção interna na área de preservação, é obrigado a pagar outorga também. Aí, foi criado no mesmo dia a Lei ํํ102, que fez com que a CDURP passasse a ser o órgão gestor da obra, da companhia, e através do decreto municipal foram transferidos todos os serviços públicos para a CDURP, e aí foi feita a PPP. O que é a PPP? A CDURP contratou uma concessionária para fazer todos os serviços públicos aqui dentro, e com os certificados, os Cepacs dos terrenos que tinham aqui, foram transferidos isso através de um leilão para fim do Porto Maravilha, administrado pela Caixa Econômica. E ele se responsabilizava para fazer os aportes de capital aqui dentro. A grosso modo, essa operação é uma operação de 15 anos, já rodou sete anos e pouco e tem mais sete anos de rodar. Já foram investidos 5 bilhões e tem mais 5 bilhões pra fazer investimentos de obras de infraestrutura. Hoje, o que está faltando de obras de infraestrutura basicamente é a Francisco Bicalho, a do Livramento, um pedaço da Central do Brasil e a Rua Santo Cristo, o resto já foi feito toda a área de infraestrutura. Que significava derrubar a Perimetral, fazer o túnel Marcello Alencar, túnel 450, a urbanização, fazer a Binário, que não existia na época, fazer um túnel na Binário, ali na rádio, fazer o Boulevard na orla e revitalizar tudo isso. Na infraestrutura, o que a gente faz quando a gente fala de revitalização através da infraestrutura: você troca toda parte de água, esgoto, iluminação pública é 
rebaixada, toda iluminação pública passa a ser com LED e alguns lugares com lâmpadas inteligentes que tenha a câmera e wi-fi, cabeamento de fibra óptica tudo subterrâneo. O sistema de drenagem é completamente modificado e recapeado, ele revê o calçamento de toda região, é basicamente isso e aí. Aí você teve os empresários que compraram terrenos e que compraram Cepac e construíram as áreas aqui ditas comerciais. Quando o governo Crivella começou, o índice de desocupação era de 92\%, ou seja, fizeram um investimento muito grande, megalomaníaco, onde você não tinha demanda suficiente pra isso e se pegou um mercado em clara descendência. Hoje, o índice de desocupação está na ordem de $47 \%$, e as grandes empresas começaram a vir pra cá. Mas foi renegado a um segundo plano toda parte de habitação, não foi feita na verdade, agora o desafio é trazer gente para morar aqui. Esta região como um todo, ela tem 0,46\% da população do Rio mas, esta região no entorno dela, demanda praticamente quarenta e cinco por cento dos empregos da cidade então você tem pouca gente morando, muito emprego gerado. Que que isso faz? Faz com que tenha um fluxo dos outros lugares todos pra cá. O ideal seria adensar essa área pra você ter, usando as facilidades aqui e os empregos que tem. Para isso foi feito também uma outra parceria pública privada que é o VLT, que deu a mobilidade urbana aqui. A médio prazo, longo prazo, tem que sair dessa área tudo quanto é ônibus daqui. Já está em funcionamento, a gente já tá falando que tem que sair, isso é uma briga enorme! Então, em rápidas palavras eu dei o que é pra você, eu tenho uma postura que tem tudo isso que eu falei.

Mas o desenvolvimento do projeto em si, teve algum envolvimento da CDURP, nessa concepção do projeto?

A CDURP é o órgão gestor. Toda parte de concepção foi feito pela CDURP.

E como foi com a população que já existia nessa região, pro pessoal do Conceição, do Pinto, da Providência?

Isso foi um passivo, nós herdamos do governo passado, porque no projeto original propunha-se uma reurbanização da Providência e do Pinto, em 2012, o Eduardo resolveu tirar 381 milhões de reais que era pra fazer isso, pra fazer o Museu do Amanhã, pra dar pra Fundação Roberto Marinho explorar, isso ficou um passivo social enorme para a população daqui. 
Isso não tem a ver com o Morar Carioca? Já fazia parte do Porto Maravilha inicialmente?

Sim, do Porto Maravilha. O projeto Morar carioca não tinha aqui nessa área, hoje como é que a gente faz pra tentar minimizar o impacto desse passivo social que nós herdamos do governo passado: a gente tenta fazer cooperativas com as pessoas, as empresas daqui da região nós incentivamos a contratar as pessoas que moram aqui na comunidade para trabalhar que é uma forma de você pagar esse passivo. Já viu que eu sou bem crítico, né?

Na verdade, o maior desafio e a expectativa que se tinha com a implementação imagino que seja a ocupação desses espaços...

Não, na verdade, o que acontece, essa é uma coisa que fala-se muito. Tem um cara que era o presidente do sindicato, ele fez um artigo um dia falando sobre a gentrificação desta área, eu acho que não tem gentrificação nesta área até porque como você tem pouca gente morando aqui dentro na verdade você não tem. O que é gentrificação, é quando você faz uma reurbanização numa área e você expulsa as pessoas, espontaneamente o poder econômico expulsa essa população. Aqui, na verdade, você não tem as pessoas morando aqui, aqui sempre foi um entreposto comercial. Na verdade, quando você fixa as pessoas aqui, você não tá fazendo a gentrificação, você está na povoando uma área. Essa discussão sobre gentrificação é uma coisa que é complicada no mundo todo, se você vai revitalizar uma determinada área, vai haver a gentrificação, porque aquela área passa a ser mais estudada, o poder econômico faz com que as pessoas comprem residências ou espaços ocupados pelo pessoal mais pobre e eles são expulsos naturalmente. Isso aconteceu no East Side, em Barcelona, em todo lugar aconteceu. E isso vai acontecer, qual é o dilema agora: não faz e deixa deteriorar ou faz e tem gentrificação. É a palavra da moda, que vocês urbanistas adoram falar e os sociólogos também.

Em relação ao, eu não cheguei a ver nada parecido além do mirante do Valongo, existia alguma ideia de realização das praças já existentes nessas regiões ou fazia parte do primeiro projeto?

Isso aí já tá pronto, onde já foi feita a revitalização, as praças já foram revitalizadas, aqui São Francisco da Prainha, Valongo, agora nós inauguramos mais três praças 
aí que ninguém vê, uma lá na Diná de Queiroz que é o lugar que é lá embaixo, o outro ao lado de onde vai ser a roda gigante que a gente chama de Praça Bacen e vai ter uma outra em frente a rodoviária. Ou seja, a partir de um momento você vai criando áreas vezes e a hora que fizer aqui na da Livramento ou Santo Cristo, normalmente as áreas vão ser criadas. Aquelas ramblas, onde tem os galpões ali, na Pereira Reis, ali foram criadas áreas verdes cruzadas que a gente chama de rambla, é um ganho aí que o projeto tá dando pra cidade.

\section{E a ideia do projeto de habitação é na Rua do Livramento?}

Não. Você tem duas coisas, tem um projeto seguinte, o sujeito pode construir aqui do lado, comprar um terreno, o inaudível comprou aqui na frente pra fazer um projeto que chama inaudível é um projeto comercial como outro qualquer, o inaudível é dele. Nessa área aqui do Livramento você não pode construir gabarito alto, tem que ser no máximo quatro, cinco andares, ali é pra minha casa minha vida, tá. Então ali tem vários projetos. Aí as pessoas falam aí em fazer 5 mil Minha Casa Minha Vida, é impossível fazer aqui, não tem espaço pra você. A menos que vá fazer no Morro da Providência, em cima, mas nessa área não tem. Esta área é não inaudível, é uma área que você não pode crescer, não pode adensar. Dá pra fazer pelos nossos cálculos aí, alguma coisa da ordem de oitocentas a mil e duzentas unidades Minha Casa Minha Vida, mas tem que fazer chamamento, tem aí Francisco Rubião, que tem um projeto Minha Casa Minha Vida entidades, mas eles são ineficientes, eles perderam o prazo, o poder público não pode nem ajudar. Eles tá lá perdendo, é um terreno enorme, que é praticamente em frente ali, antes da Cidade do Samba, aonde uma escola de samba invadiu, a Vizinha Faladeira, ali é pra fazer o projeto habitacional Minha Casa Minha Vida, mas eles perderam os prazos, eu chamei os caras aí, “vocês perderam o prazo aqui, teve chamamento”.

Então hoje em dia é mais na Rua do Livramento mesmo...

Onde tem Minha Casa Minha Vida projetado pela Secretaria de Habitação é na área do Livramento, aquela região onde era a Unilever e na região do Santo Cristo.

\section{E quanto o incentivo para uso misto?}

Tudo aqui pode ser uso misto. 


\section{E há algum incentivo para isso?}

Não tem, a única diferenciação que você tem entre comercial e residencial é que, no comercial você precisa de mais Cepac por metro quadrado e no residencial você precisa de menos. E não conta no comercial hoje, as áreas comuns verticais e horizontais, então não conta com área construída, no comercial conta, você precisa de Cepac. E também na área residencial você hoje precisa de uma garagem para cada quatro unidades.

\section{No comercial?}

Não, no residencial. Comercial não. inaudível e tem que pagar Cepac porque é área construída. Você não tem Cepac carimbado para área residencial, e você não tem áreas aqui carimbadas para residencial ou comercial. Quem concebeu isso aqui, lá atrás não queria que fizesse Guetos na verdade, ou seja, vou fazer um lugar aqui que só tenha residências, um lugar que só tem área comercial, com isso se cria como é na Barra da Tijuca, que é um Gueto mas de classe alta.

E, quando foi concebido, como é que ficou essa questão dos afastamentos e do gabarito dos edifícios?

Isso ficou definido por lei.

Mas quando se considerou isso, se levou em conta a questão de ventilação, sombreamento, essas coisas?

Uma coisa é... aqui tem tudo, aqui tem o histórico, essas áreas a gente chama de não “cepacável”, aqui pode construir cinquenta andares, aqui quarenta, aqui trinta. Essa é a relação que se tem de coeficiente de potencial. Aqui você já tá considerando os afastamentos, tá. Você não pode pegar um terreno de dez por dez e levantar um prédio de cinquenta andares, não pode fazer isso, tem que ter todo o projeto urbanístico, que é o código de obras de ventilação, tudo mais. Isso foi levado em consideração, aqui a quantidade de Cepacs que precisa para cada área, para residencial e comercial [...]. Aqui é a parte financeira do jeito que foi modulado, aqui são os terrenos que existem na área comercial para gerar recursos, você tem tudo aqui, o que já foi feito de estrutura e a delimitação da área. 
Algumas entrevistas eu vi o pessoal do IPN, chegou a comentar que tinha uma parceria bacana com vocês, dos pretos novos, que sempre davam o suporte que podia ser dado.

Por quê? Eles acham que devem viver às custas do Estado?

Não, eles estavam falando como um elogio.

Não, foi cortado tudo. Porque na verdade o Estado não tem que ser pai de todo mundo. Na verdade eles não acreditam, quando foi feito o lançamento do Cepac, você tinha uma verba do Cepac que era 3\% do valor de 3 bilhões e meio, era 14 milhões e foi criado um fundo pela Lei $\mathrm{n}^{\mathbf{0}}$ 101, para criar um Fundo para preservação culturais e históricos, esse dinheiro acabou. O Eduardo pegou praticamente $75 \%$ e deu pra fundação Roberto Marinho fazer a museografia do Museu do amanhã e do MAR. E pra essas pequeninhas, o IPN recebia oito mil reais por mês, eu cheguei aqui e essa conta, esse fundo, tinha 1.600 reais, eu falei quer? Leva esses 1.600, eu não posso pegar dinheiro de outro fundo e dar. Porque durante esse tempo todo vocês nunca tentaram fazer nada, queriam só mamar na teta do Estado. Essa área cultural, patrimonial acha que o Estado tem que ser o provedor de tudo, eles nunca correram atrás para eles fazerem. Ou seja, o IPN, como que eu posso ajudar, eu cedo meu auditório para você fazer um curso de mestrado aqui e cobrar ingresso. Você tem que ser autossustentável, não dá para o estado ficar bancando todo mundo em cima disso, tá. Eu sou muito duro, vale pro IPN e vale pra todo mundo, a briga minha é com a Fundação Roberto Marinho, que eles levaram tudo daqui e acham que são donos de um museu que foi construído pelo poder público. Eles que vão lá em Cannes receber o prêmio, aí perguntaram quanto que a fundação gastou e eu respondi provavelmente algumas passagens de primeira classe pra ir pra Paris e algumas diárias de hotel seis estrelas lá no Ritz para receber o prêmio. A Globo não gosta da gente por causa disso.

Inicialmente o próprio museu não fazia parte da primeira concepção do projeto. Não era, o Eduardo tirou o dinheiro que era pra fazer a urbanização do Morro do Pinto e da Providência pra fazer o museu. 
E acabou que essas regiões hoje, elas não receberam essas obras de infraestrutura não tão contempladas nessas regiões porque foram retiradas do primeiro projeto que contemplava essa parte de drenagem. E o que era concebido inicialmente?

Era a infraestrutura, pavimentação, rede de água e esgoto, meio fio, rebaixamento de toda energia elétrica, mesmo assim ainda foi feita uma grande caixa d'água lá cima do Morro do Pinto, você tem uma adutora, você tem um sistema de esgotamento sanitário que joga lá no Alegria, você tem aí mais ou menos quarenta quilômetros de tubulações que foram feitos em cima. A ponto que, quando chove, você vê falar de Lagoa Rodrigo de Freitas, de Jardim Botânico mas não vê mais falar daqui do Porto. Enche claro, mas a hora que para, esgota e acabou. O JB ficou dois dias.

Em relação a parte de sustentabilidade vocês consideraram, há concepção de sustentabilidade de forma geral? Vocês fizeram iluminação LED nos postes...

Sim, arborização, jardinamento.

A parte da destinação do lixo vai pro Caju?

Sim, normal. É feita pela CDURP e quando não tem problema financeiro, que é com a Caixa, é a gente que faz tudo. Quando tem é a Comlurb que ajuda. Agora ela tá fazendo por razões de necessidade, mas como não tem fluxo financeiro a concessionária está fazendo só o estritamente contratual que ela precisa fazer, que é manutenção do túnel.

Então quando tem um problema quem assume isso é a Comlurb?

Somos obrigados na verdade. É a CDURP que assume e pede pra Comlurb, porque afinal eu não tenho caminhão de lixo. Mas geralmente é a porto novo que faz, ela é remunerada para isso. Como a Caixa não está dando fluxo financeiro, está dizendo que está ilíquida o fundo da Caixa, apesar de dever ainda 4 milhões e 700 pra cá, eles tem que parar, a Porto Novo, os acionistas não podem colocar dinheiro do bolso, então eu peço ajuda a Comlurb.

E é feita a coleta em toda região?

Toda região. 
E pra onde que é destinado?

Para os depósitos de lixo, de Seropédica, depósitos que a Comlurb tem.

E foi pensado algum tipo de geração de energia alternativa ou posto de reciclagem?

Pensamos em fazer um lá no Caju, tem um projeto.

Lá perto do parque ecológico.

É mas não depende só da gente, mas a gente tem um projeto pra isso aí. Agora a gente tinha um processo seletivo, tipo desses contêineres e tivemos que fechar porque os cracudos vinham aí e entravam lá dentro e arrebentaram.

\section{ÁUDIO PARTE 2}

Eu só tenho mais uma pergunta sobre as audiências públicas.

Eu não estava aqui.

Eu não consegui muita informação de como era a divulgação e o envolvimento. Se as pessoas chegaram a participar antes...

Antônio liga para os colegas

Ela vai ter que ir a Campo Grande, em Mato Grosso. Tem mais ninguém aí... 


\section{Anexo 4 - Modelo de questionário elaborado}

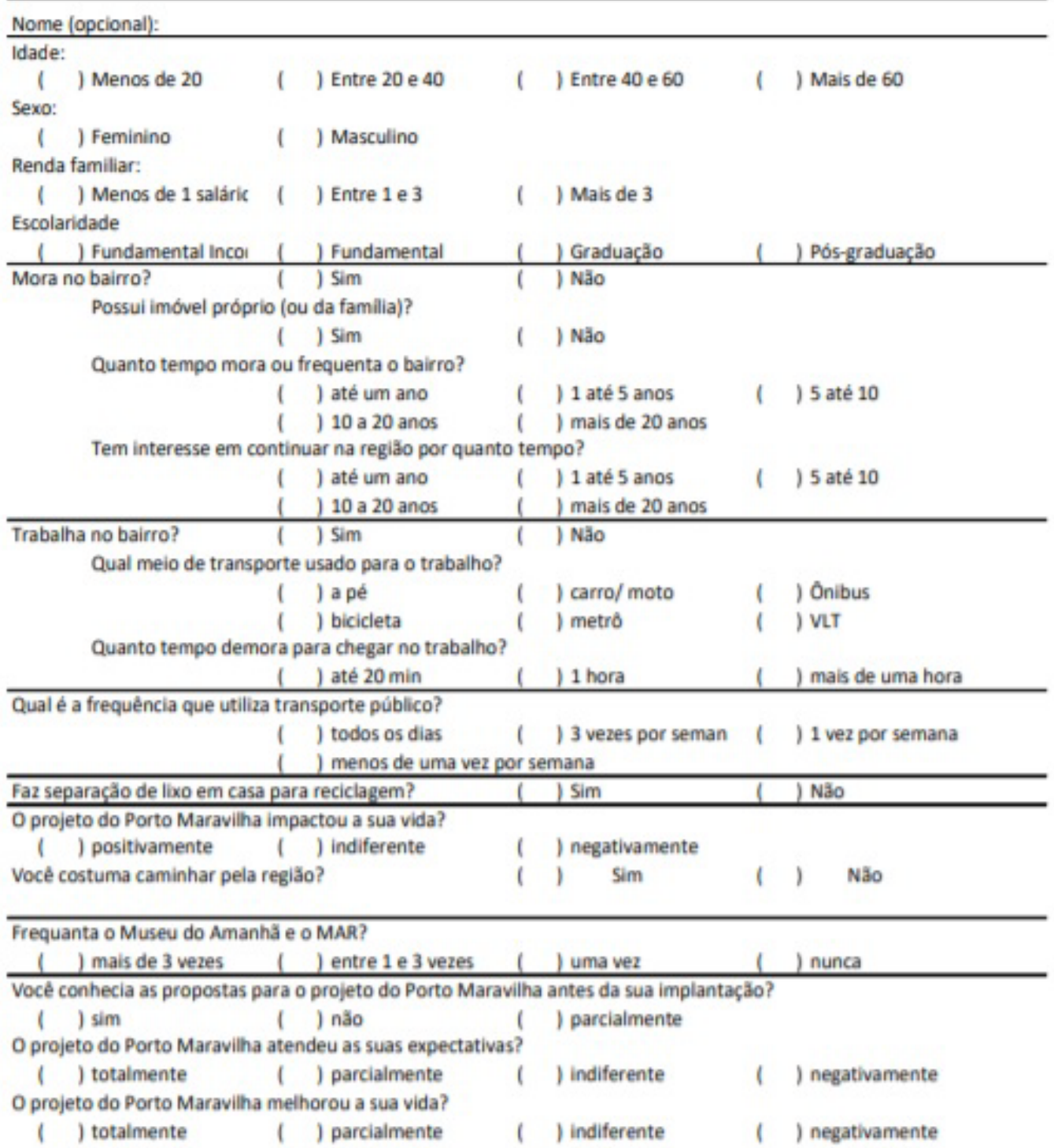

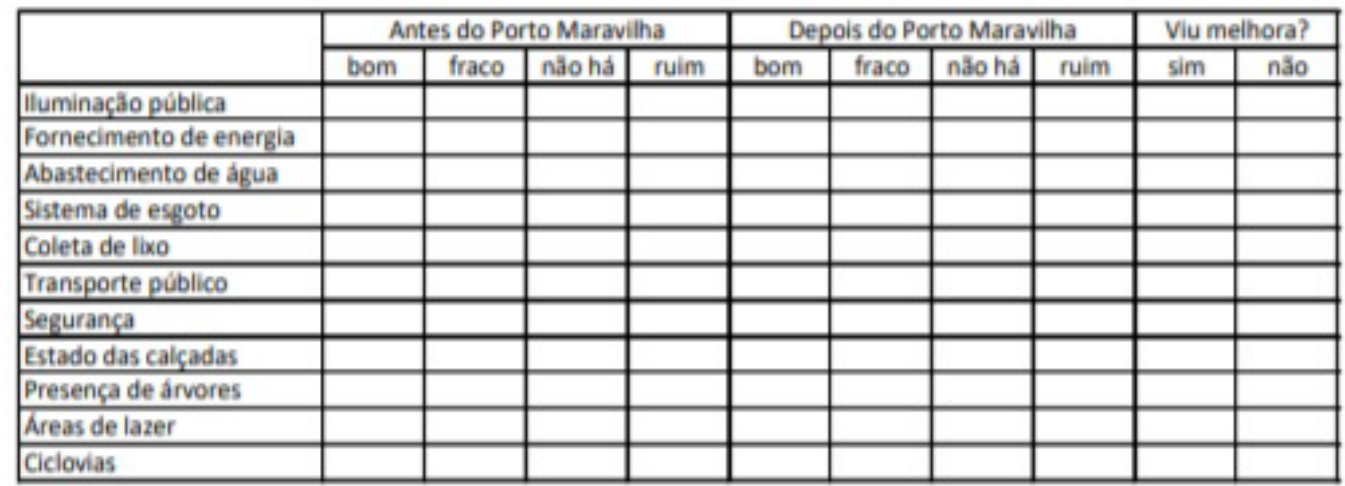

